\begin{abstract}
UNIVERSIDADE DE SÃO PAULO
FACULDADE DE FILOSOFIA, LETRAS E CIÊNCIAS HUMANAS

DEPARTAMENTO DE LETRAS CLÁSSICAS E VERNÁCULAS

PROGRAMA DE PÓS-GRADUAÇÃO EM ESTUDOS COMPARADOS DE

LITERATURAS DE LÍNGUA PORTUGUESA
\end{abstract}

CRISTIANE NAVARRETE TOLOMEI

Eça de Queirós e os brasileiros

São Paulo

2010 


\author{
UNIVERSIDADE DE SÃO PAULO \\ FACULDADE DE FILOSOFIA, LETRAS E CIÊNCIAS HUMANAS \\ DEPARTAMENTO DE LETRAS CLÁSSICAS E VERNÁCULAS \\ PROGRAMA DE PÓS-GRADUAÇÃO EM ESTUDOS COMPARADOS DE \\ LITERATURAS DE LÍNGUA PORTUGUESA
}

\title{
Eça de Queirós e os brasileiros
}

Cristiane Navarrete Tolomei

\begin{abstract}
Tese apresentada ao Programa de PósGraduação em Estudos Comparados de Literaturas de Língua Portuguesa do Departamento de Letras Clássicas e Vernáculas da Faculdade de Filosofia, Letras e Ciências Humanas da Universidade de São Paulo, com vistas à obtenção do título de Doutor em Letras.
\end{abstract}

Orientador: Prof. Dr. Hélder Garmes 
Às minhas duas famílias:

uma, que me acompanha por toda a vida; outra, que nasceu juntamente com este trabalho. 


\section{AGRADECIMENTOS}

Ao meu orientador Hélder Garmes, pela orientação sábia.

À professora Elza Miné, por me guiar no início da pesquisa com maestria e companheirismo.

Ao professor Paulo Motta, que apresentou sugestões valiosas na qualificação.

À professora Fátima Bueno, pelas observações pertinentes durante a qualificação.

Às funcionárias do Centro de Estudos das Literaturas e Culturas de Língua Portuguesa (CELP), Creusa e Mari, pelo apoio e amizade.

À amiga Cláudia Maria Fernandes Corrêa, pela amizade sincera e divertida, pelo carinho e pelas reflexões a respeito do mundo.

À amiga Silvia Dafferner, pelos momentos de aprendizado que passei ao lado dela.

À amiga Flávia Rodrigues Benfatti, pelas conversas importantes sobre a vida.

À amiga Luciana Prudente Guiotti, pelo apoio importante na reta final do trabalho.

Às amigas Daniela, Patrícia e Gisele, companheiras de toda vida.

À amiga Marli Baldini, que me mostrou a seriedade da profissão.

Às minhas famílias, pela força e entusiasmo e, principalmente, por acreditarem em mim.

À Coordenação de Aperfeiçoamento de Pessoal de Nível Superior (CAPES), pelo auxílio financeiro que trouxe tranquilidade durante a pesquisa. 
TOLOMEI, C. N. Eça de Queirós e os brasileiros. Tese (Doutorado em Letras, Área de Concentração: Estudos Comparados de Literaturas de Língua Portuguesa). Universidade de São Paulo, São Paulo, 2010.

\section{RESUMO}

Este trabalho analisa o delineamento da imagem do escritor português José Maria Eça de Queirós (1845-1900) no Brasil, tomando como base a crítica seminal queirosiana brasileira e verificando como se dá o diálogo entre ela e outras leituras críticas sobre o autor até o final do século passado. Para a realização deste estudo, dividiu-se a crítica queirosiana produzida no Brasil em três momentos: o primeiro, que remonta à primeira crítica de peso sobre Eça, escrita por Machado de Assis, em 1878 até 1942, último livro sobre o escritor que antecede as comemorações da primeira efeméride em 1945, conjunto de textos aqui definido como crítica seminal; o segundo, que apresenta as publicações baseadas no modelo dessa crítica seminal, realizando releituras dos textos fundadores entre as duas grandes efemérides, de 1945 e de 2000; e finalmente o terceiro, que apresenta as publicações não seguidoras da crítica seminal, inaugurando novas abordagens à respeito da vida e da obra de Eça, perfazendo o mesmo período entre 1945 e 2000. Resta, então, demonstrar como a crítica seminal permanece, ainda hoje, como fundamento da imagem vulgarizada do escritor no Brasil.

Palavras-chave: Eça de Queirós; Brasil; crítica; recepção; leitores. 
TOLOMEI, C. N. Eça de Queirós e os brasileiros. Tese (Doutorado em Letras, Área de Concentração: Estudos Comparados de Literaturas de Língua Portuguesa). Universidade de São Paulo, São Paulo, 2010.

\begin{abstract}
This work analyses the design of the image of the Portuguese writer José Maria Eça de Queirós (1845-1900) in Brazil, based on the Brazilian seminal queirosian critique and verifying how the dialogue between such criticism and other critical readings about the author is established until the end of last century. For this study, the queirosian critique produced in Brazil was divided in three stages: the first, dating back to the first relative important critique about Eça, written by Machado de Assis in 1878 and it runs through until 1942 with the last book about the writer preceding the anniversary of the first ephemeris in 1945 with a set of texts, defined here as seminal critique; the second, featuring the publications that resumed the model of this seminal critique, by rereading the founding texts between the anniversaries of the two major ephemerides: 1945 and 2000 and finally, the third stage presents the publications that did not follow the seminal critique, opening new approaches concerning the life and work of Eça, making the same period between 1945 and 2000. Thus, it demonstrates the way in which the seminal criticism remains until nowadays as a founding element of the widespread image of the writer in Brazil.
\end{abstract}

Key words: Eça de Queirós; Brazil; criticism; reception; readers. 


\section{SUMÁRIO}

INTRODUÇÃO

\section{CAPÍTULO I}

\section{CRÍTICA SEMINAL (1878 A 1942): \\ AS PRIMEIRAS PUBLICAÇÕES SOBRE EÇA NO BRASIL}

A gênese da crítica literária brasileira sobre Eça de Queirós

1 Machado de Assis: a pedra basilar no caminho da canonização da obra queirosiana no Brasil.

2 Miguel Mello: Eça, o domínio da linguagem. 27

2.1 O estudo da obra .29

2.1.1 O estilo e a linguagem queirosiana...... .29

2.1.2 A elaboração dos personagens. 36

2.1.3 As fases da obra queirosiana. 38

2.2 O estudo da vida .42

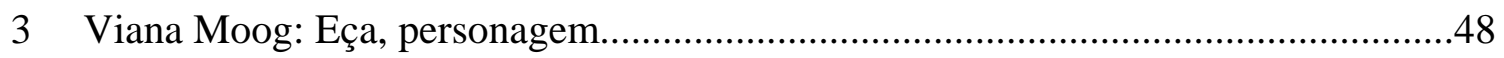

3.1 A abordagem psicológica da infância de Eça...............................................50

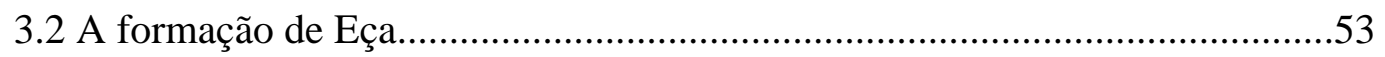

3.3 A autobiografia de Eça...........................................................................56

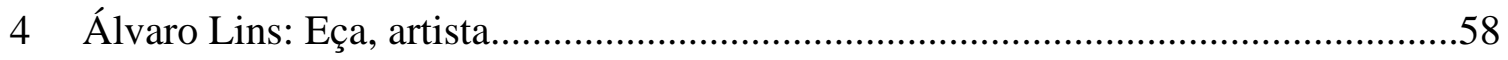

4.1 A formação inicial de Eça..........................................................................60

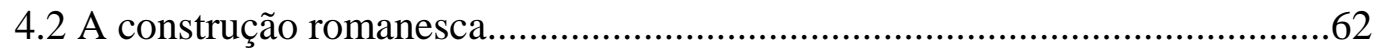


4.3 A centralidade dos personagens...................................................................66

4.4 Eça e a política...............................................................................................68

4.5 O Eça de Álvaro Lins....................................................................................69

5 José de Melo Jorge: Eça, criador de tipos........................................................................71

5.1 Os personagens tipos: retratos da vida de Eça..................................................72

6 Clóvis Ramalhete: Eça, uma presença invisível...............................................................84

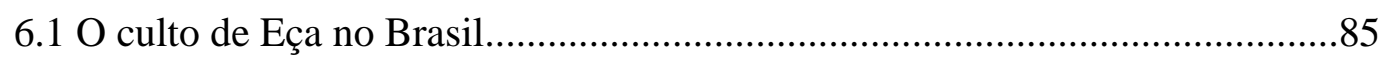

$6.2 \mathrm{O}$ processo de escrita de Eça...........................................................................90

6.2.1 Eça, cronista.............................................................................91

6.2.2 Eça, romancista...........................................................................93

6.2.3 Eça, correspondente de jornais.....................................................95

\section{CAPÍTULO II}

ECOS DA CRÍTICA SEMINAL

A herança da crítica seminal sobre Eça de Queirós no Brasil...............................................99

1 A análise sócio-histórica sobre Eça..........................................................................99

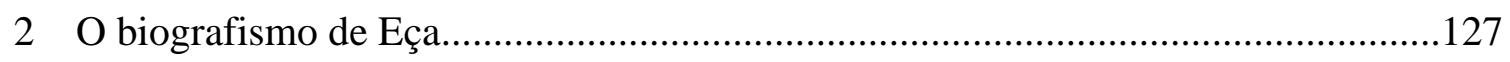

3 A leitura de Eça pela perspectiva psicológica...............................................................146

\section{CAPÍTULO III \\ ALGUNS NOVOS OLHARES A RESPEITO DE EÇA DE QUEIRÓS}

A ruptura da crítica seminal sobre Eça de Queirós no Brasil..............................................153

1 A tensão dialética na obra queirosiana.....................................................................153

2 A interpretação estilística da obra queirosiana..........................................................155 


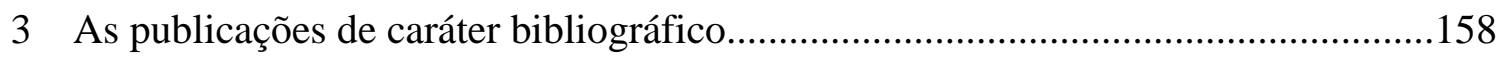

3.1 O levantamento bibliográfico de Eça de Queirós........................................158

3.2 O levantamento bibliográfico sobre Eça de Queirós....................................169

4 A linguagem queirosiana como instrumento social...............................................174

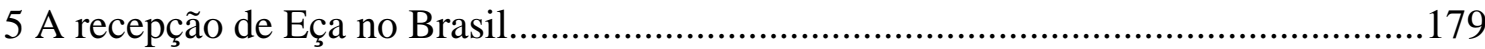

6 As visões contemporâneas sobre Eça.........................................................................186

CONSIDERAÇÕES

FINAIS

191

BIBLIOGRAFIA

ANEXO

Quadro cronológico das publicações em formato de livro no Brasil durante o século XX 
Eça, quando não vê a olho nu, põe a luneta; quando não vê com a luneta, pega no microscópio; e, se a noite é tenebrosa, transformase em tigre; e, se o olhar felino não é ainda bastante perspicaz, transforma-se em vidente, em iluminado.

Guerra Junqueiro 


\section{INTRODUÇÃO}

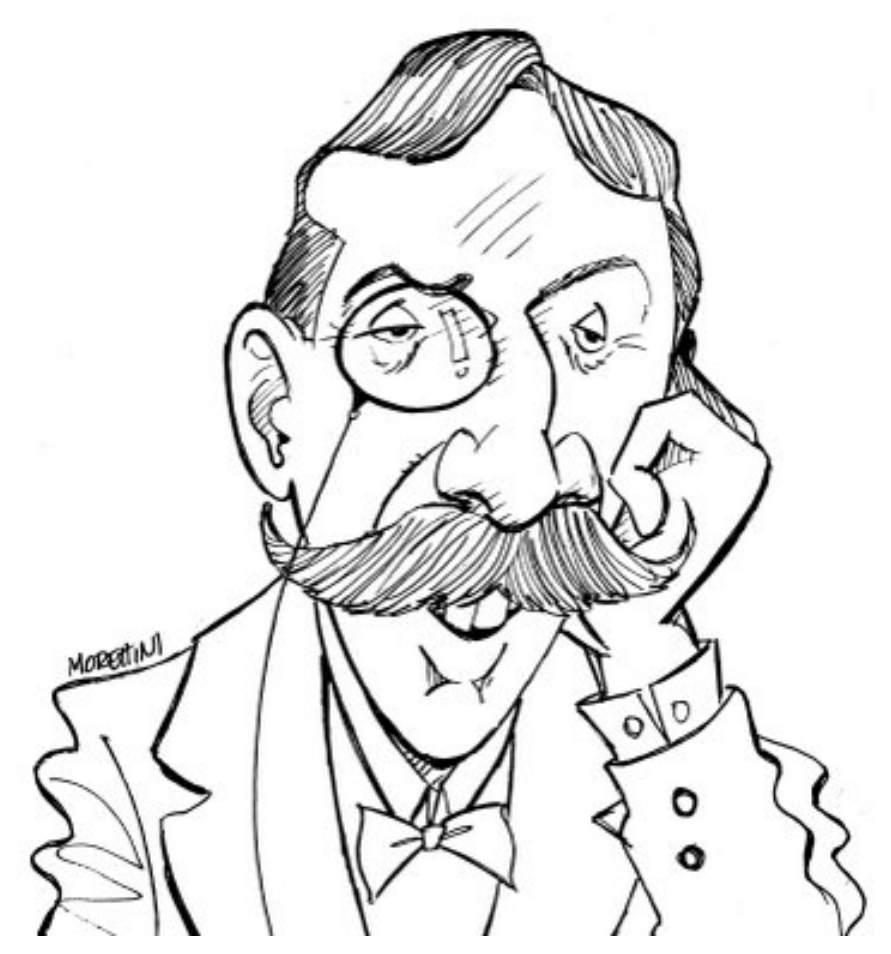

Eça de Queirós foi, assim, ajustado ao que era o modo de escrever, digamos normal do seu tempo na Europa. Homem desse tempo, ele captou-lhe a cor própria e a incorporou à sua prosa incomparável, transmitindo-a às sucessivas gerações de leitores. Daí, talvez, a relativa constância do efeito que exerce sobre estes, fazendo com que leiamos hoje de maneira relativamente próxima à dos nossos pais e avós. 
A produção escrita do autor português, Eça de Queirós (1845-1900), sempre foi acompanhada por estudiosos de diversas áreas de atuação, que analisaram a obra do escritor em diferentes momentos e espaços.

No Brasil, a obra queirosiana recebeu - e continua recebendo - um número significativo de leituras críticas guiadas sob prismas diferentes. A respeito disso, o renomado queirosiano Frederico Perry Vidal afirma que

o estímulo ao culto do mito ecista no Brasil parte naturalmente de universidades, institutos de pesquisa, academias, centros de estudos, gabinetes de leitura, liceus literários, casas de cultura, editoras, fundações culturais, companhias de teatro, jornais, revistas literárias que dedicam à efeméride edições comemorativas - do que é exemplo "Encontro", do Gabinete Português de Leitura de Pernambuco - revistas não dirigidas, mas que agora abrem espaço generoso para as infinitas sugestões a que conduz a arte queirosiana, e um pouco, também, da maioria das instituições luso-brasileiras, largas centenas em todo o país, quantos dispondo de bibliotecas que significam patrimônio valioso, muitas vezes ignorado. Em paralelo, especialistas reunidos em eventos da mais variada inspiração monopolizam a atenção dos estudiosos, com particular destaque para o "III Encontro Internacional de Queirosianos", realização vitoriosa do Centro de Estudos Portugueses da Universidade de São Paulo [...]

Daí a iniciativa espontânea de escritores, filólogos, dramaturgos, historiadores da literatura, pensadores, críticos, poetas e ensaístas; de escultores, de pintores e de outros artistas plásticos, sem menosprezar o reino poderoso de criatividade vibrante da caricatura, da charge e também dessoutro, singularmente sugestivo, do cinema e da televisão... a todos os imprevisíveis domínios da arte, que a imaginação tem o direito de atingir (VIDAL, 1995, p. 11).

De modo geral, Perry-Vidal retrata a contribuição do Brasil para a construção da imagem de Eça e a divulgação da obra do realista. Em consonância com essa ideia, outro conhecido queirosiano da atualidade, Carlos Reis, enfatiza que

a fortuna brasileira de Eça de Queirós é antiga, diversificada e não isenta de controvérsia. Para ela contribuíram escritores, artistas plásticos, universitários, leitores anônimos e, em muitos casos, uma cultura queirosiana feita de intensa devoção: devoção propriamente literária, gastronômica e comportamental (REIS, 2000, p. 23). 
De acordo com os excertos, o coro de vozes que fala de toda parte - e ao mesmo tempo - e que se multiplica, marca o intenso interesse dos brasileiros por Eça de Queirós. Observa-se também o contingente rico e diversificado de leituras que foi aumentando gradativamente desde a época do escritor até hoje. De acordo com Isabel Pires de Lima,

ontem como hoje, cem anos após a sua morte, Eça é lido, relido e estudado por brasileiros e portugueses com idêntico interesse. Uma tal perenidade é sinal indiscutível da elevada dimensão artística e da atualidade da obra queirosiana. Exatamente porque produziu arte através da linguagem, obsessiva e penosamente trabalhada até ao último momento da publicação, é que Eça de Queirós se mantém atual e continuamos, brasileiros e portugueses, a lê-lo com paixão. A atualidade e a perenidade de um escritor decorrem sobretudo da capacidade de os seus textos gerarem sempre novos leitores, produzirem ao longo dos tempos novas interpretações, convidarem à constante revisitação (LIMA, 2000, p. 69). ${ }^{42}$

Assim, o presente trabalho procura apresentar o papel da crítica literária sobre Eça no Brasil, tendo em vista as perspectivas críticas e o processo de construção da imagem do autor, que sofreu mudanças durante o século XX. Para desenvolver este estudo, o corpus é constituído por publicações em formato de livro uma vez que ele exerce, na sociedade, um poder maior de legitimidade da produção intelectual. O livro apresenta um valor simbólico superior às outras formas de produção intelectual escrita, como, por exemplo, o periódico, a revista, o panfleto. Desse modo, o livro pode ser tomado como um símbolo do prestígio do autor e da obra. Além disso, em vista de sua extensão, propicia a análise crítica mais detalhada do que um artigo ou ensaio, colocando-se mais facilmente como referência para a reflexão acerca de um escritor.

Por conseguinte, busca-se, por meio dos estudos queirosianos publicados em volume durante o século $\mathrm{XX}$, visualizar como a crítica, enquanto mediadora entre os

\footnotetext{
${ }^{42}$ Este trecho sofreu alteração na mudança da norma linguística portuguesa para a brasileira. No decorrer deste trabalho, sempre quando necessário, ocorrerá esse tipo de modificação.
} 
produtos de bens simbólicos ${ }^{43}$ e o público, teve o poder de legitimar a obra de Eça no âmbito da cultura designada erudita, além de atuar como instância significativa na consagração desse autor juntamente ao público. Como nota Bourdieu (1974), é por intermédio da atuação da crítica que muitas obras entram para o cânone literário e Eça, apesar de ter caído no gosto popular, chegando mesmo a ser considerado um autor dotado de um erotismo excessivo, não fora exceção à regra e teve na crítica os mais árduos defensores de seu valor literário.

Tendo em mente a importância da crítica brasileira na divulgação de Eça no século passado, esta foi dividida em três momentos distintos, para ilustrar o aprimoramento dos estudos queirosianos no país e, consequentemente, apresentar o delineamento da imagem do autor a partir das diferentes publicações que levaram o leitor brasileiro a imaginar a figura do escritor de diversos ângulos.

Inicialmente, privilegia-se a primeira crítica exponencial sobre o escritor no Brasil, elaborada por Machado de Assis, em 1878 (apresentando-se, por sua importância, como a única exceção ao formato livro que caracteriza o recorte deste trabalho), passando-se de imediato para as publicações em livro de 1911 a 1942, quando ocorre o lançamento do último volume sobre o escritor antes das comemorações da primeira efeméride em 1945. Considera-se este conjunto de textos como crítica seminal, pois servirá de base para grande parte dos estudos subsequentes.

No segundo momento da tese, apresentam-se as publicações que retomaram o modelo da crítica seminal, realizando releituras ou se apropriando das abordagens críticas dos textos fundadores entre as duas grandes efemérides, de 1945 e de 2000.

\footnotetext{
${ }^{43}$ Cf. BORDIEU, Pierre. A economia das trocas simbólicas. São Paulo: Perspectiva, 1974.
} 
No terceiro e último momento, apresentam-se as publicações que se distanciaram da crítica seminal, inaugurando novas abordagens à respeito da vida e da obra de Eça, perfazendo o mesmo período entre 1945 e 2000.

Desse modo, ao reunir algumas leituras brasileiras sobre Eça do século passado, verificando o que escreveram sobre o autor em momentos distintos e com abordagens também diferentes, observa-se como a crítica seminal lançou as primeiras diretrizes que, ainda hoje, são tomadas como fundamento da imagem mais vulgarizada do escritor no Brasil e como isso contribuiu para a imagem "mediática” do autor. Ademais, é importante salientar que, ao tomar-se aqui a crítica queirosiana brasileira de forma independente da portuguesa - ou da internacional -, isso se faz apenas como uma estratégia metodológica para viabilizar uma leitura histórica em larga escala. Desse modo, a crítica brasileira sobre o autor é aqui tomada como indício da crítica queirosiana como um todo, fazendo com que funcione como uma espécie de metonímia da crítica sobre o autor português, sem pretender caracterizar sua especificidade e desconsiderar a importância da crítica portuguesa e internacional no delineamento da imagem contemporânea do escritor. 


\section{CAPÍTULO I}

CRÍTICA SEMINAL (1878 A 1942):

AS PRIMEIRAS PUBLICAÇÕES SOBRE EÇA NO BRASIL

sta

Uma coisa fica dos grandes gênios: o contorno literário de sua personalidade. É como um retrato moral que se fixa na imaginação e que se vai reproduzindo através dos longos tempos.

Eça de Queirós 


\section{A gênese da crítica literária brasileira sobre Eça de Queirós}

Este "Primeiro Capítulo” apresenta o resultado da observação sobre as publicações em formato de livro sobre a vida e a obra de Eça de Queirós no Brasil entre 1911 e 1942. Considera-se esse período a inauguração dos estudos queirosianos no país uma vez que surgem os primeiros textos mais completos sobre o autor português.

Embora a preocupação neste trabalho esteja voltada à análise dos volumes, acredita-se que não poderia deixar de citar o trabalho seminal da crítica eciana brasileira publicada por Machado de Assis na segunda metade do século XIX. A importância da crítica machadiana de 1878 sobre a obra realista-naturalista de Eça é vista até hoje como referência aos estudos tanto brasileiros quanto portugueses à produção literária do escritor lusitano.

A crítica de Machado abriu caminho para que outros brasileiros se interessassem pela obra queirosiana e passassem a divulgá-la, interpretá-la, analisá-la e tomá-la como patrimônio comum entre Brasil e Portugal. O posicionamento crítico de Machado chamou atenção de outros estudiosos da época e passou a orientá-los, de certa forma, em futuras leituras sobre a obra de Eça. A visão do escritor brasileiro a respeito de O Primo Basílio (1878) ${ }^{44}$ desencadeou posicionamentos críticos que percorreram a crítica do século XX.

Do texto de Machado até o ano da primeira publicação crítica em formato de livro no Brasil, em 1911, os leitores brasileiros intensificaram a sua aproximação com a obra de Eça, dando início ao chamado culto ao escritor português no país. Esse processo de conhecimento da obra queirosiana dá ao Brasil lugar de destaque na divulgação e análise dos textos queirosianos, já que a recepção no país foi mais intensa do que a dos

\footnotetext{
${ }^{44}$ A data de publicação do livro somente será empregada na primeira vez em que o texto for mencionado.
} 
portugueses $^{45}$. Em uma concepção mais atual sobre esse assunto, Benjamin Abdala Júnior afirma que

Eça de Queirós radicou-se no Brasil, embora aqui não colocasse seus pés, através do poder de um subcampo intelectual renovador, formado nos inícios de nossa República. A atuação dos agentes críticos desse campo abriu-lhe as páginas dos jornais brasileiros e o escritor português veio a ter mais leitores no Brasil do que em seu país de origem. Esse fato se explica pelo entrecruzamento das expectativas do escritor e seu público-leitor, entre estes e os mediadores críticos (ABDALA JR., 2000, p. 99).

De 1878 a 1880, a relação entre Eça e o Brasil fora atribulada e confusa (iniciada com a viagem de D. Pedro II em Portugal, satirizada por Eça e Ramalho ${ }^{46}$. No entanto, quando o escritor português tornou-se o correspondente na Europa de A Gazeta de Notícias, do Rio de Janeiro, a relação entre ele e os brasileiros se solidificou e perduraria por vinte anos ${ }^{47}$, até 1900 , quando da morte do autor.

As duas primeiras décadas do século XX foram marcadas pelas publicações póstumas e inéditas de Eça, além de o aumento considerável de estudos sumários sobre a biografia e obra do autor. Foi nesse momento que surgiu o primeiro livro dedicado exclusivamente à pesquisa sobre o autor português escrito por Miguel Mello em 1911 e intitulado Eça de Queiroz.

Nas duas décadas que se seguiram, as publicações de obras póstumas e inéditas de Eça foram uma constante no mundo editorial, tanto em Portugal quanto no Brasil, assim como foram recorrentes publicações sobre a obra do autor português na imprensa brasileira $^{48}$. Nas três décadas subsequentes, inúmeros intelectuais brasileiros abordaram a vida e a obra do escritor português como tema de variada publicação. Um conhecido

\footnotetext{
${ }^{45}$ Conforme Paulo Cavalcanti em Eça de Queiroz agitador no Brasil (1959), Heitor Lyra em O Brasil na vida de Eça de Queiroz (1965), Arnaldo Faro em Eça e o Brasil (1977), entre outros.

${ }^{46}$ Cf. FARO, Arnaldo. Eça e o Brasil. São Paulo: EDUSP, 1977.

${ }^{47}$ Como é sabido a relação de Eça com o Brasil ainda permanece de forma marcante, pois a fortuna crítica queirosiana brasileira tem aumentado consideravelmente com o passar dos anos.

${ }^{48}$ Esse assunto será tratado mais profundamente em Antônio Simões dos Reis.
} 
exemplo dessa dedicação foi Gilberto Freyre ${ }^{49}$ que não escondia sua admiração por Eça e, muito menos, sua identificação intelectual e artística com o escritor português. No mesmo período - além do número incontável de artigos, capítulos de livros, verbetes de enciclopédias e outros gêneros de texto sobre Eça -, as publicações em forma de livro floresceram e mais outros quatro volumes foram publicados até o início da década de 1940: Eça de Queiroz e o século XIX (1938), por Viana Moog, História Literária de Eça de Queiroz (1939), por Álvaro Lins, Os tipos de Eça de Queiroz (1940), por José de Melo Jorge e Eça de Queiroz (1942), por Clóvis Ramalhete.

O lançamento desses cinco volumes em conjunto com outros tipos de publicações contribuiu para a criação de um laço afetivo entre o autor e o seu público brasileiro. Afrânio Peixoto, certa vez, mencionou esse quadro da seguinte maneira: "Eça foi o vento largo de ideias, foi a forma fresca, irreverente, do mais ameno bom humor que já conheceu a nossa linguagem. Isto é a explicação de um êxito, maior aqui do que na própria mãepátria” (apud AYRES, 1983, p. 188) ${ }^{50}$.

Esse grupo pioneiro representa a crítica seminal dos estudos queirosianos no país e é responsável pela difusão de uma abordagem crítica, vinculada a uma visão extrínseca da obra literária. Em outras palavras, eles trazem ao público o biografismo de Eça e mostram como é possível ver a obra do escritor português como reflexo de sua própria vida.

\footnotetext{
49 Cf. GOMES, Vânia Regina. O aprendiz de Fradique Mendes. Eça de Queirós na leitura de Gilberto Freyre. São Paulo: 2006, 157f. Dissertação (Mestrado em Estudos Comparados de Literaturas de Língua Portuguesa) - Faculdade de Filosofia, Letras e Ciências Humanas - Universidade de São Paulo, São Paulo. Cf. OLIVEIRA, Paulo Motta. Gilberto Freyre leitor de Eça. In: SCARPELLI, Marli Fantini; OLIVEIRA, Paulo Motta (orgs.) Os centenários de Eça, Freyre, Nobre. Belo Horizonte: FALE/UFMG, 2001, p. 341-352. ${ }^{50}$ A citação em forma de apud é utilizada neste estudo, quando não foi possível encontrar a fonte primária do texto citado.
} 


\section{Machado de Assis: a pedra basilar no caminho da canonização da obra queirosiana no Brasil}

Machado de Assis (1839-1908), certa vez, afirmara que por ele poderia se dispensar de voltar a falar do texto de Eça de Queirós, afirmação anunciada pelo brasileiro quando fora praticamente obrigado a retomar a sua crítica de 16 de abril de 1878, depois de 14 dias, em função da grande polêmica gerada, a partir dali, acerca de sua crítica ao romance O Primo Basílio. Também, como ele, se poderia dar por encerrada a discussão em torno da crítica machadiana, visto que esta já foi exaustivamente discutida pela historiografia literária brasileira e portuguesa. Porém, ela ainda é motivo de debate e, sobretudo, considerada neste estudo a pedra fundamental de todas as críticas que surgiriam posteriormente, portanto, a relevância de revisitá-la.

A crítica de Machado de Assis fora e ainda é tomada com extremo respeito e valorizada na forma como trata a obra queirosiana. Além de ser considerada a responsável pela abertura e divulgação da produção artística do escritor português no Brasil, a crítica machadiana, segundo Paulo Franchetti, também “até hoje orienta a apreciação crítica de $O$ Primo Basílio no Brasil, sendo citada praticamente toda vez que se analisa o romance de Eça” (FRANCHETTI, 2000, p. 48).

O texto crítico foi publicado nas páginas de O Cruzeiro e pode ser dividido em dois momentos: o primeiro, que faz a análise da obra queirosiana em torno de nova tendência literária que surgia na época, o Naturalismo, de Zola; e o segundo, que faz a análise do que Machado entendia ser os problemas de concepção e de construção do texto de Eça, especificamente no tratamento da criação dos personagens e da estrutura narrativa.

Ao comentar o primeiro momento, José Maria Bello (1952) ressalta que o artigo de Machado foi um exemplo de uma "crítica de defeitos": 
Creio que ninguém antes, no Brasil e, possivelmente, em Portugal, teria posto em relevo com tamanha acuidade e tamanha severidade os aspectos falsos do Naturalismo. Creio também que ainda não se teria feito uma apreciação tão penetrante dos dois grandes romances de Eça de Queirós. Penetrante, mas muitas vezes de clamorosa injustiça, porque inspirada por evidente prevenção (BELLO, 1952, p. 155).

Na citação de Bello, já é possível averiguar o tom polêmico da crítica machadiana, pois ao mesmo tempo em que ela representaria a melhor crítica, seria também o terreno de batalha entre naturalistas e aqueles que se colocavam contra a nova corrente literária. Para ilustrar essa visão polêmica em torno da obra do escritor português, retornar-se-á às primeiras linhas da crítica de Machado:

Um dos bons e vivazes talentos da atual geração portuguesa, o Sr. Eça de Queirós, acaba de publicar o seu segundo romance, O Primo Basílio. O primeiro, $O$ Crime do Padre Amaro, não foi de certo a sua estreia literária. [...] O Crime do Padre Amaro revelou desde logo as tendências literárias do Sr. Eça de Queirós e a escola a que abertamente se filiava. O Sr. Eça de Queirós é um fiel e aspérrimo discípulo do Realismo propagado pelo autor do Assomoir (ASSIS, 1946 [1. ed. 1878], p. 160$161)^{51}$

Machado afirmara que O Crime do Padre Amaro (1876) servira somente para que o escritor português pudesse apresentar aos seus leitores seu posicionamento estéticoliterário. Ademais, o autor brasileiro desenvolvera a hipótese de plágio ao alegar o caráter imitativo do Crime.

Que o Sr. Eça de Queirós é discípulo do autor do Assomoir, ninguém há que o não conheça. O próprio $O$ Crime do Padre Amaro é imitação do romance La Faute de l'Abbé Mouret. Situação análoga, iguais tendências; diferença do desenlace; idêntico estilo; algumas reminiscências, como no capítulo da missa e outras; enfim, o mesmo título (ASSIS, 1946 [1. ed. 1878], p. 161).

\footnotetext{
${ }^{51}$ Como o objeto deste estudo é amplo e percorre diferentes momentos históricos, nos quais a língua portuguesa apresentou diferentes ortografias devido à diferença espaço-temporal, optou-se por uniformizá-la fazendo as devidas atualizações.
} 
Machado, ainda vinculado aos preceitos românticos, advertira os leitores da sua época sobre o posicionamento estético-literário embasado no realismo-naturalismo. Assim, verifica-se que o crítico brasileiro passara a fazer um levantamento dos problemas do Naturalismo, cujos defeitos atingiriam a produção do romance de Eça.

Este homem tem faculdades de artistas, dispõe de um estilo de boa têmpera, tem observação; mas o seu livro traz defeitos que me parecem graves, uns de concepção, outros da escola em que o autor é aluno, e onde aspira a tornar-se mestre; digamo-lhe isto mesmo, com a clareza e a franqueza a que têm jus os espíritos de certa esfera (ASSIS, 1946 [1. ed. 1878], p.175).

Nesse excerto, Machado de Assis não esconde a admiração por Eça. Todavia, condena o posicionamento estético do escritor português e abre caminho para o segundo aspecto de sua crítica, ao apresentar o que entende ser os defeitos narrativos do texto, empregando, para tanto, os pressupostos da escola naturalista. O crítico brasileiro considerara pouco convincente a construção dos personagens, principalmente o de Luísa, assim como mal elaborada a trama:

Luísa é um caráter negativo, e no meio da ação ideada pelo autor é antes um títere do que uma pessoa moral.

Repito, é um títere; não quero dizer que não tenha nervos e músculos; não tem mesmo outra coisa; não lhe peçam paixões nem remorsos; menos ainda consciência.

[...]

Um leitor perspicaz terá já visto a incongruência da concepção do Sr. Eça de Queirós, e a inanidade do caráter da heroína. Suponhamos que tais cartas não eram descobertas, ou que Juliana não tinha a malícia de as procurar, ou enfim que não havia semelhante fâmula em casa, nem outra da mesma índole. Estava acabado o romance, porque o primo enfastiado seguiria para a França, e Jorge regressaria do Alentejo; os dois esposos voltavam à vida exterior (ASSIS, ano [1. ed. 1878], p. 165-168).

Para Machado de Assis, havia em O Primo Basílio duas tramas: a de Luísa e Basílio e a de Luísa e Juliana. Nesse aspecto, a principal contestação à crítica de Machado refere-se à elucubração deste sobre a hipótese de Juliana não descobrir as cartas e acabar o 
conflito e, portanto, acabar ali o romance. Machado queria demonstrar com isso que a trama entre Luisa e Juliana nada tinha a ver com o triângulo amoroso Luísa, Jorge e Basílio. Muitos críticos, no entanto, entenderam que Machado, dessa forma, estaria propondo outro romance e não aquele que Eça de fato escrevera, o que invalidaria sua crítica.

Apesar de Machado ter condenado alguns aspectos do Primo, não negara o mérito do texto, quer pelo estilo empregado por Eça, quer pela boa elaboração da personagem Juliana, considerando-a “o caráter mais completo e verdadeiro do livro [...]” (ASSIS, 1946 [1. ed. 1878], p. 167). E, além da construção dos personagens em O Primo Basílio, Machado apresentara uma preocupação em torno do decoro do texto, especialmente no que julgava como emprego excessivo de erotização.

Parece que o Sr. Eça de Queirós quis dar-nos na heroína um produto da educação frívola e da vida ociosa; não obstante, há aí traços que fazem supor, à primeira vista, uma vocação sensual. A razão disso é a fatalidade das obras do Sr. Eça de Queirós - ou, noutros termos, do seu Realismo sem condescendência: é a sensação física. [...] Ora, o tom é o espetáculo dos ardores ${ }^{52}$, exigências e perversões físicas. Quando o fato lhe não parece bastante caracterizado com o termo próprio, o autor acrescenta-lhe outro impróprio (ASSIS, 1946 [1. ed. 1878], p. 170-171).

Nesse trecho, nota-se que Machado considerara que, em função dos preceitos naturalistas, o texto se tornara apelativo. Acreditava ser desnecessário o uso do erotismo do modo como o fizera Eça. Em vista disso, Machado ataca mais uma vez a nova estética com base na construção do enredo e na presença do que acreditava ser imoral.

Se eu tivesse de julgar o livro pelo lado da influência moral, diria que, qualquer que seja o ensinamento, se algum tem, qualquer que seja a extensão da catástrofe, uma e outra coisa são inteiramente destruídas pela viva pintura dos fatos viciosos: essa pintura, esse aroma de alcova, essa descrição minuciosa, quase técnica, das relações adúlteras, eis o mal. A castidade inadvertida que ler o livro chegará à última página, sem fechá-lo, e tornará atrás para reler outras (ASSIS, 1946 [1. ed. 1878], p. 184-185).

\footnotetext{
${ }^{52}$ Essa expressão motivara, na época, muitas especulações e criações de charges e piadas.
} 
Mais do que condenar o erotismo em O Primo Basílio, Machado reprovara a concepção naturalista do romance, apontando para o que entende ser sua imperfeição artística. A respeito desse assunto, Machado da Rosa (1964) manifesta-se da seguinte forma:

A originalidade da crítica machadiana assentava num sistema de ideias em que se fundia uma visão aparentemente pragmática dos movimentos romântico e naturalista com uma penetração excepcional dos fenômenos psicológicos e da verdade moral. [...] Para Machado o autor do Crime é aluno, fiel e aspérrimo, de Zola. O seu êxito não se devera apenas ao trabalho real do homem talentoso (e não simples copista), mas às novidades do Realismo, impenitente e iconoclasta. O maior sucesso do Primo não provinha de ser superior ao romance de 1876, mas da reincidência e do "requinte de certos lances", expressão decorosa que provavelmente incluía as cenas do Paraíso, "que não destoaram do paladar público". Aos olhos da maioria o mérito mais saliente dessa estética era a "do pomo defeso".

Machado negava que o Realismo de Eça no Primo ministrasse qualquer ensinamento moral. [...] Quer dizer, a obra literária tem que ser a idealização dramática de uma dor moral. Desse princípio, tão radicalmente ausente dos postulados naturalistas que constituíam a novidade e a atração de momento, talvez derive a maior força de Machado como crítico de Eça - e, por ironia, a sua fraqueza (ROSA, 1964, p. 226-228 - grifo nosso).

Machado da Rosa, no seu alentado estudo sobre a aproximação entre Eça e Machado, afirma que, para o escritor brasileiro, a função da literatura era a de desempenhar um papel modelar e não o papel polêmico e de exposição do que entendia ser a hipocrisia burguesa que o escritor português propunha ao adotar o Naturalismo de Zola.

De acordo com Paulo Franchetti (2000), a interpretação da crítica de Machado deve ser realizada tendo em consideração o lugar de onde fala o escritor brasileiro. Desse modo, a leitura sobre a crítica machadiana deve ser entendida e, por sua vez, justificada pelo fato de ele a ter escrito em um período de transição entre o Romantismo e o Realismo no Brasil e de afirmação de uma tradição literária nacional. Destarte, trazendo a visão "de um escritor empenhado na criação de uma tradição cultural no Brasil e que, por isso mesmo, 
lia o texto de Eça de uma perspectiva muito interessada” (FRANCHETTI, 2000, p. 49), condenando aquilo que considerava inadequado para essa tradição, o que incluía a estética naturalista.

Entende-se que a polêmica sobre a crítica de Machado possivelmente ocorrera pelo fato de que o escritor brasileiro estava vivendo um período de impasse entre um Machado romântico e outro que nasceria realista. Dessa forma, diante de tal situação, Machado, em 1878, vivia uma crise do ponto de vista literário, de modo que produzira uma crítica dominada por um decoro romântico, mas que já balizava as diretrizes que o norteariam em sua adoção de uma estética realista.

A crítica de Machado recebeu inúmeras leituras. Por exemplo, no início até meados do século XX, um setor da crítica literária brasileira especializada em Eça - como Viana Moog, Álvaro Lins e José Maria Bello -, rejeita alguns aspectos da crítica machadiana à medida que se tratava de suposições relacionadas ao uso do condicional: "Se tal personagem fizesse isso” ou "Se ocorresse tal ação da seguinte forma”, desconsiderando o que de fato Eça escrevera. Em contrapartida, encontra-se Manuel Bandeira e Agripino Grieco assinalando que a crítica realizada por Machado sobre o Primo foi “a melhor página da crítica brasileira” (GRIECO, 1959, p. 131).

Na segunda metade do século XX, Roberto Schwarz, por exemplo, julga que "havia da parte de Machado uma intenção realista neste antirrealismo conservador, se o considerarmos expressão de experiência e ceticismo - o que não era na Europa, onde representava um recuo intelectual - em face do cabimento das ideias liberais no Brasil” (SCHWARZ, 1977, p. 65). Era uma postura conservadora que repensava o Realismo e a forma de representar o real. Julga-se que a crítica de Machado é um grande momento da crítica literária brasileira, visto poder ser lida como a própria invenção do Realismo machadiano e como interlocução privilegiada na formação literária de Eça de Queirós e em 
sua difusão entre os leitores brasileiros. Em relação ao exposto, concorda-se com Carlos Reis (2000) quando afirma que

esse episódio em muitos aspectos fundador fica como um momento fugaz, mas muito significativo, da interação literária que chegou a existir entre os dois maiores romancistas da língua portuguesa; e fica também como evidência do interesse que a obra de Eça suscitou no Brasil desde muito cedo (REIS, 2000, p. 24).

Assim, foi a partir da crítica de Machado que Eça adquiriu, pela primeira vez, lugar de destaque no cenário literário brasileiro, ganhando, a partir daí, muitos admiradores e seguidores. 


\section{Miguel Mello: Eça, o domínio da linguagem}

E mal iria a quem escreve estas linhas a veleidade de lhes ir às mãos. Nem corrigir, nem contrapor-se pelo exemplo. Impele-o só o intento de ensaiar reconstruir ao menos suas linhas gerais, uma biografia que já devera ter sido feita pelos competentes. Instiga-o aos demais disso o desejo de comentar por alto uma obra excepcional e já popularizada, ainda mal vista pela maioria dos seus apreciadores.

Miguel Mello

É desse modo que Miguel Mello (1877-1929) dá início ao seu "Proêmio” ao primeiro livro sobre a vida e a obra do escritor português no Brasil e no mundo intitulado Eça de Queiroz (1911), publicado pela Livraria Italiana e Tipografia Ramori do Rio de Janeiro.

Eça de Queiroz é publicado cinco anos antes do primeiro livro lançado em Portugal por António Ferreira Cabral Pais do Amaral $^{53}$ e, mesmo sendo o primeiro livro sobre Eça, Miguel Mello supunha que era um livro que estava sendo publicado tardiamente e que, na opinião dele, especialistas do escritor português deveriam ter tomado à frente e publicado antes dele. Ainda a respeito disso, Mello esclarecia ao leitor que o seu texto não poderia ser considerado uma crítica literária, mas, apenas apontamentos de um “admirador confesso”, que não estava preocupado em julgar o trabalho de Eça; pelo contrário, Mello enfatiza que o objetivo dele era defender o escritor português das principais acusações feitas a ele e a sua obra.

Esse livro pioneiro e admirável (por ter sido escrito em um tempo em que não havia muitas informações sobre a vida e a obra de Eça) é resultado do empenho de Miguel

\footnotetext{
53 Segundo Campos Matos, “cabe o mérito ao conselheiro António Cabral de ter sido o primeiro biógrafo português de E.Q., com a publicação em 1916 da obra, E.Q., a Sua Vida e a Sua Obra. Cartas e Documentos inéditos ( $3^{\text {a }}$ edição, melhorada, em 1945), numa época em que quase tudo se ignorava da vida do escritor e se encontrava por publicar grande parte da obra póstuma” (MATOS, 2000, p. 73).
} 
Mello, que consegue um importante documento para sua elaboração: a resposta a um questionário, via carta, dada pelo filho do escritor, José Maria Eça de Queirós, resultando em um instigante relato a respeito do pai.

Brito Broca também ressalta o aspecto pioneiro da crítica de Mello, destacando o “quanto Eça preocupava os intelectuais brasileiros da época” (BROCA, 1960, p. 123) e como, até 1914, “o culto de Eça de Queirós foi maior no Brasil do que em Portugal” (BROCA, 1960, p. 123). Mas, apesar do grande esforço de Mello, Brito Broca aponta algumas falhas no livro:

Embora trazendo como epígrafe "a obra e o homem”, o estudo ressentese um pouco da falta de unidade, tendo resultado de artigos dispersos que $\mathrm{o}$ autor procurou sistematizar. Na parte relativa à biografia, Miguel Mello escusou-se de não fazer trabalho mais completo, alegando escassez de dados, e declarando que só numa viagem a Lisboa se poderiam obter subsídios necessários. Outras falhas do livro decorreram também dessa carência de elementos informativos. Onze anos após a morte do romancista, os portugueses, que tinham ao alcance tais elementos, não haviam começado a vulgarizá-los (BROCA, 1960, p. 123).

Embora o livro de Mello apresente algumas omissões referentes à vida e à obra de Eça, vale ressaltar que o crítico brasileiro é guiado por três fundamentos: "o intuito biográfico", “o desejo de comentário” e o "bosquejo sobre a personalidade do escritor" (MELLO, 1911, p. 9). Logo, para a realização de seu estudo, Mello sistematiza a sua pesquisa, dividindo-a em duas partes: a primeira, denominada "Esboço crítico", faz um percurso sobre a obra de Eça, destacando o estilo e a criação de personagens tipos, além de focalizar os galicismos dentro da obra do escritor; e a segunda, denominada "Traços biográficos”, é dedicada ao estudo da vida de Eça, subdividida em três momentos - os “Primeiros tempos”, a “Estreia à maturidade” e os “Últimos tempos”. 


\subsection{0 estudo da obra}

Nota-se que Mello, ao analisar a obra de Eça de Queirós, escolhe dois temas básicos para nortear o seu estudo: o estilo e a linguagem queirosiana e a divisão em fases da obra do autor. No primeiro tema, o brasileiro desenvolve uma argumentação sobre a beleza da linguagem de Eça e os recursos que o escritor utilizara para que ela fosse inovadora; e, no segundo tema, Mello é categórico ao afirmar que a obra de Eça apresentara uma divisão que indica uma primeira fase englobando os livros mais revolucionários e uma segunda fase reunindo os últimos livros do autor.

Assim, o crítico brasileiro lança as primeiras diretrizes de estudo sobre a obra queirosiana, que serão centro de discussão durante o século XX.

\subsubsection{O estilo e a linguagem queirosiana}

Miguel Mello destaca o estilo de Eça de Queirós como sendo uma de suas principais características, assinalando que, mediante o seu estilo inovador para a segunda metade do século XIX, o escritor português tornara-se figura importante nas letras. A forma de escrever de Eça é descrita da seguinte forma por Mello:

Maravilha-nos a fluência cantante do seu estilo, sem arestas nem rugosidades, num rolar de períodos sonoros, mordendo fundo o ouvido. Encanta-nos, tão espontâneas lhe sabem as ardilezas de expressão, a certeza de ter sido a sua pena guiada por um temperamento extraordinariamente simpático. Cada um de nós tem a impressão de serem aquelas linhas buriladas por um amigo incomparável, para nosso gozo pessoal (MELLO, 1911, p. 6-7).

Destacam-se desse trecho três expressões: “impressões”, “por um amigo incomparável” e "para nosso gozo pessoal”. Na primeira, “impressões”, verifica-se a 
presença da crítica impressionista, inserida em uma parcela dos estudos críticos que defendiam a emissão de juízos subjetivos ou, em outras palavras, um posicionamento crítico embasado em sensações pessoais sobre uma produção literária. Na segunda, "por um amigo incomparável”, destaca-se o desejo de aproximação com o objeto de estudo ou, no caso de Mello, com o criador da obra. Essa proximidade, entrando já na terceira expressão, é recorrente na crítica queirosiana da primeira metade do século XX, porque os críticos desse período concebiam a obra de Eça como algo muito familiar, de modo que se sentiam ligados àqueles textos “por gosto pessoal”. Evidenciavam o prazer da leitura e não a necessidade de sua função social, o que sugere um caminho oposto ao de Machado de Assis que via, na produção literária, papel de reflexão da realidade.

Para Miguel Mello, o prazer em ler a obra de Eça estava na originalidade da escrita do autor português. Assim, qualificando o escritor como um grande artista das letras já que dominava a linguagem no sentido de que esta conseguisse transmitir a realidade por intermédio da ironia.

\footnotetext{
Creem as naturezas vulgares na possibilidade de um artista como Eça de Queirós, por inspirações de botequim, gastar a vida na manipulação de chalaças, no inócuo prazer de provocar a explosão de gargalhadas. Não lhe desvendam os cegos o valor tremendo da obra de combate, onde o faiscar da ironia não era senão uma arma de vitória certa. Um recurso para a consecução de um fim (MELLO, 1911, p. 12).
}

Miguel Mello, analisando a obra de Eça, é capaz de verificar que a ironia fora um elemento visceral da produção queirosiana e importante recurso de crítica política já que, por meio dela, o autor português atingira “a fundo uma sociedade em desmantelo" (MELLO, 1911, p. 12) e, especialmente, de acordo com o crítico brasileiro, Eça trouxera a coragem de levantar o cenário deprimente de um país dominado pelo passado. Sobre isso, Mello afirma: “Eu, de mim, só tenho louvores para o homem que veio quebrar a rotina dos insinceros elogios, dos tradicionais louvores às mesmas inferioridades da Pátria, entoados 
pelos que dormiam na exploração das glórias extintas dos Lusíadas” (MELLO, 1911, p. 12).

Ao valorizar a presença da ironia na obra de Eça, Miguel Mello apresenta seu gosto particular pela obra do autor português mais uma vez, pois enfatiza a sua opinião quando reitera o que estava afirmando com a expressão “Eu, de mim, só tenho louvores”. Todavia, esse gosto pessoal era partilhado com muitos de seus contemporâneos, assim como o será por toda crítica posterior, revelando que o subjetivo aqui tem seu grau de objetividade analítica.

Observa-se, na crítica de Mello, uma preocupação em torno da forma como a estética realista aparecia na obra de Eça. Ao mesmo tempo em que ele identifica os aspectos do realismo como a crítica social, a caricatura, a psicologia dos personagens e a situação típica que convergem em uma única imagem um todo humano social e histórico, ele nota que o autor fizera, em alguns momentos da sua escrita, uma retomada ao passado português. Embora esse posicionamento do autor causasse certo estranhamento por parte do crítico, este consegue distinguir o retrato que Eça realizara do passado de Portugal daqueles realizados por Camões e Almeida Garrett.

A perenidade das observações de Mello pode ser constatada na análise recente que Benjamin Abdala Jr. (2000) faz de A Ilustre Casa de Ramires (1900), argumentando que Eça repudiava a resolução dos problemas de Portugal por meio do retorno ao seu passado glorioso e acrescentando a esse argumento que o autor português acreditava no presente e na realidade portuguesa. Para Benjamin, Eça criticara qualquer tipo de máscara da realidade para amenizar a verdadeira situação de Portugal: “Eça, a esse tempo, continuava a não aceitar a estreiteza desse nacionalismo folclórico, provinciano” (ABDALA JR., 2000, p. 112). De certa forma, isso já estava enunciado em Miguel Mello. 
No entendimento de Mello, Eça só conseguira manifestar o seu desejo de revelar a realidade portuguesa, porque adotara como princípio em sua obra colocar à mostra os costumes da burguesia, a caricatura dos dirigentes portugueses, o desafio ao clero e, por último, as consequências do convencionalismo de um país decadente. Nessa perspectiva, Mello diz que a obra de Eça “é a mais encantadora porque ninguém, em nenhuma literatura, mostrou nunca saber com felicidade mais hilariante apanhar num relance o cômico, e sentir de golpe o traço caricatural das naturezas que se deformam em obediência às convenções” (MELLO, 1911, p. 15). Nesse trecho, nota-se que Mello dá à obra de Eça um caráter original e desbravador, pois, para ele, era a única que resgatava do trágico o lado cômico, que registrava as regras da sociedade e as via de maneira irônica. Salienta-se que os termos empregados pelo crítico como "encantadora” e "hilariante” mostram, mais uma vez, o seu ponto de vista pessoal perante a produção escrita do autor, sem, contudo, desqualificá-la como unilateral, pois conta com a anuência do leitor.

Mello cita a função social da linguagem da obra queirosiana para introduzir o motivo que levara Eça produzir uma literatura realista: o autor português como a sua geração viveram a transição entre a Monarquia e a República, o que resultaria em um movimento de autocrítica à imagem portuguesa. Verifica-se que, sobre isso, Mello nota na obra de Eça uma preocupação com o aprofundamento do trauma para ultrapassá-lo, por isso a necessidade de retratar a realidade, que, no caso de Eça, ocorria via ironia.

O crítico brasileiro apresenta um Eça preocupado com as novas concepções que estavam surgindo no final do século XIX: "Simbolistas, satânicos, impressionistas, decadentes [...]” (MELLO, 1911, p. 20). E, segundo Mello, nesse turbilhão, Eça aderira ao Realismo, retirando desse movimento os melhores atributos: 
Assimilou as qualidades superiores dessa escola que tão grande benefício prestou às letras, fixando os tons dos coloridos justos, surpreendendo soberbamente as atitudes e os gestos de flagrante verdade, completando as descrições, rodeando as ações com pormenores de absoluta propriedade e plasticisando as línguas com o luxo de uma abundante beleza nunca antes atingida (MELLO, 1911, p. 21).

Mello destaca o domínio sobre a linguagem exercida por Eça como um dos grandes aspectos da obra do autor e afirma que a habilidade no manuseio dos recursos linguísticos era facilitador para a realização do retrato da sociedade portuguesa. Todavia, mesmo fazendo referência à linguagem queirosiana, Mello não se aprofunda na análise dos elementos estilísticos e linguísticos, mas trabalha a questão da linguagem como importante instrumento social $^{54}$ utilizado pelo autor português, ou seja, o crítico brasileiro abre caminho para analisar a produção literária eciana como função social. E essa interpretação da literatura como instrumento social partira do próprio autor em carta datada de 6 de agosto de 1894, retomada por Miguel Mello e redirecionada aos estudiosos ecianos que se seguiram. Por exemplo, em Portugal, Jaime Cortesão dedica um volume a esse tema intitulado Eça de Queiroz e a questão social, de 1949, e, no Brasil, Djacir Meneses com o livro Crítica social de Eça de Queiroz ${ }^{55}$, de 1950.

Miguel Mello ressalta que a elaboração artística com base nas observações sociais inicia um entusiasmo por parte do público, como é possível observar no trecho a seguir:

A sua audácia lhe teria granjeado apenas rancor geral, um ódio inexorável, se o seu modo de combater, a sua maneira de atacar, a ternura de seu estilo quente, as suas qualidades de meridional exuberante e afetuoso, não dispusessem a melhor parte do público a perdoar-lhe tudo. A quem recebe dos fados o mágico dom de uma linguagem tão cativante, de uma fluência tão original e estranhamente colorida, de um poder de expressão que consegue com palavras dar-nos a impressão mesma da vida, dizendo o que mais ninguém soube dizer, a esse tudo se consente, e todos os pecados se lhe redimem, ficando-se a dever-lhe ainda além disso uma gratidão bem fundada (MELLO, 1911, p. 25).

\footnotetext{
${ }^{54}$ Cf. BAKHTIN, M. Marxismo e filosofia da linguagem: problemas fundamentais do método sociológico na ciência da linguagem. São Paulo: Hucitec, 1979.

${ }^{55} \mathrm{O}$ estudo desse volume será apresentado no capítulo 3, que trata das novas leituras sobre Eça.
} 
Esse trecho de Mello traduz a admiração que ele tem pela linguagem queirosiana e a persistência na tentativa de convencer a nós (leitores de sua crítica) sobre a magnitude do estilo de Eça. Percebe-se, mais uma vez, que não há uma preocupação em analisar a linguagem do autor português, mas sim uma preocupação de exaltar e qualificar a produção escrita queirosiana. Mello cita uma originalidade e uma inovação da linguagem de Eça, porém ele não produz uma crítica estilística. Uma análise brasileira com essa preocupação só surgiria em 1945 em um ensaio de Aurélio Buarque de Holanda intitulado “Linguagem e estilo de Eça de Queiroz” 56, publicado no Livro do Centenário, organizado por Lúcia Miguel-Pereira e Câmara Reis. O estudo sobre o estilo e a linguagem de Eça receberia um volume mais completo com a publicação do livro de Ernesto Guerra da Cal na década de 1950.

E Mello, ao abandonar a análise intrínseca da obra, retoma a crítica impressionista para realçar o prazer da leitura, o que sugere que o texto do brasileiro é uma eterna homenagem em tom retórico ao seu ídolo. E, dentro dessa comoção de Mello, ele justifica a beleza da linguagem de Eça devido ao temperamento meridional do autor.

Embora Mello não tenha entrado em detalhes na análise da linguagem literária de Eça, comenta como o escritor recusara as fontes clássicas da língua portuguesa no intuito de dar conta da descrição da realidade de seu país, resultando no abandono de Eça da referência quinhentista ou seiscentista, interessando-lhe "uma linguagem nova, maleável, dúctil, que pudesse exprimir todas as coisas com plasticidade leve e nervosa da francesa” (MELLO, 1911, p. 27). Contudo, por que da francesa? Eça conhecia profundamente a língua francesa e via nela a solução para o que entendia ser a falta de vocabulário em

\footnotetext{
${ }^{56} \mathrm{O}$ estudo desse volume será apresentado no capítulo 3, que trata das novas leituras sobre Eça.
} 
português. Daí advém o galicismo como um dos aspectos marcantes da obra do escritor, como aborda Miguel Mello.

Para o brasileiro, Eça compreendia que seria por meio da literatura, que ele, mesmo estando longe de Portugal, poderia retratar os vícios e os erros da sociedade lusitana. Em vista disso, produzira uma literatura independente, como revela o trecho a seguir:

Eça de Queirós teve o nobre orgulho de se deixar em uma posição superior, sem descer a mercantilizar-se. Publicava os seus livros com plena independência, sem jamais rebaixar-se à bajulação dos críticos.

Afrontando as opiniões e os melindres, atirava os seus livros francamente, deixando-os fazerem por si o seu caminho, independentes de qualquer proteção.

Assim confiante no valor dos seus trabalhos, tanto lhe valeria viver no país sobre o qual a sua arte ia reagir, como fora dele. No exílio, em reclusão fecunda, dedicou-se, então, exclusivamente à paixão das letras (MELLO, 1911, p. 44).

A forma como Mello descreve a independência e a segurança de Eça perante seus textos possibilita inferir, então, que para o crítico as palavras de Machado de Assis não o teriam abalado e, muito menos, teriam feito que Eça mudasse o romance O Crime do Padre Amaro. Logo, verifica-se que Mello acredita que o autor português era único, pelo motivo de que produzia uma literatura autêntica, sem preocupações com a crítica e o mercado editorial. Essa posição do crítico brasileiro é intrigante, pois é aceitável o seu ponto de vista, mas, ao mesmo tempo, não se podem desconsiderar as cartas trocadas por Eça e amigos, nas quais toma-se ciência sobre a preocupação do escritor com relação à falta da opinião crítica a respeito do Crime o que permite questionar: Eça tinha insegurança para escrever ou era algum tipo de jogo de marketing? Ele tinha por objetivo mostrar uma imagem distorcida dele mesmo?

Miguel Mello, a partir do momento em que vê essa independência na obra de Eça ou devido ao jogo imagético ou à sátira que realizara aos costumes da época, também observa que a presença de elementos do Romantismo (clero, casamento, religião, amor) 
fora uma maneira encontrada por Eça para criticar a má influência romântica que reinava na educação em Portugal. E esse posicionamento do crítico brasileiro frente ao Romantismo na produção eciana floresce. Sobre isso afirma Carlos Reis (2005):

Eça encara o Romantismo como um dos males de que essa sociedade enferma: a sua tendência melancólica, o seu artificialismo, e a sua debilidade moral são aspectos normalmente criticados pelo romancista [...] Daí que temas como a educação, o adultério, a condição da mulher afetada pelo bovarismo ou o donjuanismo devam ser pontual ou sistematicamente conexionados com a tematização do Romantismo (REIS, 2005, p. 40-41).

À luz disso, nota-se que Miguel Mello abre um debate polêmico à respeito da presença do Romantismo na ficção queirosiana, não lhe dando fim. O que há hoje são ecos desse posicionamento, mas que já tinham sido construídos nas falas de João da Ega em Os Maias.

\subsubsection{A elaboração dos personagens}

Mello retruca àqueles que declaravam que Eça fora mais um "criador” do que um “observador” dos costumes de seu país. Retruca, também, àqueles que apontavam para um Eça plagiador, copista de Flaubert e da literatura francesa e, por fim, aceita o fato de Eça ser um “criador”, mas no sentido de "criar” e não de "inventar” como supunham. Mello defende o Eça criador de tipos e o compara a grandes nomes: "Criador de tipos foi Cervantes, ideando o D. Quixote e Sancho-Pança. Foi-o Shakespeare, concebendo o Hamlet, Othelo, o rei Lear, Romeu e Julieta. Foi-o Molière, produzindo o Tartufo, o Misantropo, as Preciosas Ridículas, e tantas outras figuras simbólicas” (MELLO, 1911, p. 54). 
O crítico brasileiro ressalta que a criação de tipos em Eça fora o resultado de uma compilação de personagens, que não foram apresentadas individualmente; pelo contrário, foram “unidos pelo fio de um caráter comum” (MELLO, 1911, p. 55). Além disso,

\begin{abstract}
aproximava esses seres em cujas almas diferentes havia pontos de contato. Fusionava-os num personagem sintético e representativo, dando-lhe assim um interesse de realce empolgante.

O Conselheiro Acácio, a criada Juliana, o genial Pacheco, o primo Basílio, João da Ega, José Matias, a tia Patrocínio, o Cônego Dias e tantas outras criações, formam uma soberba galeria humana digna de Molière.

A sua glória está justamente em não ter sido um reprodutor servil das coisas presenciadas (MELLO, 1911, p. 55-56).
\end{abstract}

Mello considera Eça como sendo um escritor híbrido, pois vê que ele criara os seus tipos de forma tão minuciosa que, partindo da lógica e da imaginação, conseguira construir seus personagens de tal maneira que os aproximara da perfeição, conseguindo a "ilusão da realidade” (MELLO, 1911, p. 56). Logo, o Eça híbrido de Mello e criador de tipos fora aquele que, “além de contemplativo e idealista, foi um observador sagacíssimo, de lápis em punho para anotar os lances interessantes surpreendidos a qualquer hora” (MELLO, 1911, p. 56). Nesse trecho, Mello retrata uma das imagens lendárias de Eça: sozinho em um banco de praça tomando anotações da realidade a sua volta. Essa imagem introspectiva do escritor faz parte da fantasia popular e que chama a atenção dos seus admiradores brasileiros. E, por fazer parte do grupo dos admiradores, Mello sintetiza a criação de Eça como obra de um olhar de artista diante do real.

Para Mello, a produção literária de Eça partira da imaginação do artista, mas não uma imaginação rodeada de vultos e de contornos; pelo contrário, fora aquela bem definida em sua mente, “como se assistisse, num teatro, a uma representação viva” (MELLO, 1911, p. 58). De forma que ele conseguisse transpor de seu pensamento para o papel, personagens tão definidos e animados pela verdade. Para o brasileiro, fora essa verdade 
dos textos queirosianos que causara impacto na sociedade portuguesa, ou, mais especificamente, na lisboeta, que nunca o perdoara pelo retrato social negativo construído pelo autor.

\subsubsection{As fases da obra queirosiana}

Para Miguel Mello e mais tarde para grande parte da crítica queirosiana, a obra de Eça pode ser dividida em duas fases nas quais a "Primeira Fase" corresponderia aos primeiros livros mais revolucionários e realistas e a "Segunda Fase”, os últimos livros considerados de conciliação entre o autor e Portugal.

Evidencia-se que Mello faz essa divisão para dar conta da explicação na mudança de direcionamento que tomara os últimos livros de Eça frente ao retrato social de Portugal. Para o crítico, o autor mudara de estratégia para fazer as pazes com o seu país e também, ao perceber que as mazelas sociais não estavam restritas à sua pátria, mas dominavam outros países como a Inglaterra e a França que o escritor considerara modelos da modernidade.

Destaca-se, na crítica de Mello, certa relutância na busca das justificativas para o novo formato das últimas publicações, pois por mais que ele exerça a função de crítico na tentativa de provar essa mudança em Eça, o brasileiro se entrega e afirma que o destaque da obra queirosiana são os livros da "Primeira Fase" por lhe causar mais emoção. Por conseguinte, ele ressalta que

em Eça de Queirós a dúvida, a ironia, o espírito iconoclástico, foram elementos de luta. Mas por ser um refletor sensibilíssimo da sociedade, cujas vibrações registrava, a sua arte deixou patente, nas últimas obras, a melancólica ternura dos homens do tempo. Reproduziu exata a ânsia dos que vão, entre as ruínas da imensa derrocada por eles próprios feita, procurar contritos os ídolos partidos, restos de fé, pontas de convicções, a que se possam apegar, para não naufragarem de todo na covardia da indiferença ou no horror do desespero (MELLO, 1911, p. 50-51). 
Nesse trecho, observa-se que Miguel Mello vê dois aspectos positivos nos livros da “Segunda Fase”: uma postura espiritualista do autor e o seu abandono pelo racionalismo materialista da época. Isto é, compreende-se que o crítico brasileiro era adepto da concepção religiosa da realidade, visão que tomou conta de grande parte da crítica queirosiana.

Concernente à produção da "Primeira Fase”, Mello destaca O Primo Basílio como a grande obra-prima de Eça do ponto de vista da concepção literária, destaca $O$ Crime do Padre Amaro do ponto de vista do social e destaca Os Maias (1888) do ponto de vista do estilo e da forma.

Sobro o Primo, Mello é indiferente às críticas realizadas a ele e afirma que "nesse livro de uma lógica sem defeitos, Eça mostra, ao lado da maldade dos adultérios de que o homem é o culpado, a futilidade da educação das mulheres: desde o colégio, do qual Luisa e Leopoldina se lembram como de um lugar de vícios” (MELLO, 1911, p. 62). Desse modo, verifica-se que o brasileiro defende a construção de uma narrativa didática que apontaria a educação viciosa da mulher como sendo um grande mal da sociedade, responsável pela “dissolução da família” (MELLO, 1911, p. 63) e acrescenta mostrando homens como Basílio, que se aproveitavam da situação, surgindo como uma

encarnação horrível de um egoísmo de argentário, ante cujo ceticismo prático todas as mulheres, mães, esposas, filhas, irmãs ou primas, são todas igualmente fêmeas, é um adventício que caracteriza perfeitamente o homem metalizado pela preocupação absorvente do dinheiro (MELLO, 1911, p. 63).

Além desses dois personagens tipos, Mello cita também os personagens secundários: Juliana, Acácio, Sebastião, Ernesto Ledesma e Julião Zuzarte. Embora todos fossem importantes, Mello concorda com Machado de Assis no momento em que ele destacara a criada como a personagem melhor elaborada por Eça. 
O tipo secundário da criada Juliana foi tratado com pormenores magistrais de tão absoluta verdade, que se tornou, pelo Realismo do desenho, a figura mais bem pintada do quadro, a personagem mais bem descrita de que se pode orgulhar toda a literatura portuguesa, um dos perfis mais vivos dos romances de qualquer país e de qualquer tempo: é uma criação genial, é shakespeareana (MELLO, 1911, p. 64).

E sintetiza a apresentação do livro da seguinte forma:

O fio ligador das cenas deste livro, o desenvolvimento dramático de sua ação, o seu contexto, enfim, é de uma lógica impecável. Não se lhe pode achar uma brecha por onde o espírito crítico penetre, denunciando uma falha de concepção, um erro de fantasia criadora. Tudo aqui é de uma possibilidade completa (MELLO, 1911, p. 65).

Se Mello concorda com Machado de Assis quanto à criação de Juliana, discorda com o argumento machadiano de que, no Primo Basílio, existiam problemas de construção. Para Miguel Mello, a perfeição desse romance era incontestável, visto que ele o vê aberto a diversas possibilidades.

Sobre o Crime, Mello, por sua vez, já não o defende de forma tão contundente como o fez com o Primo. Ele levanta, por exemplo, uma “frouxidão com que a São Joaneira assiste ao progresso da intimidade suspeita que vai ligando criminosamente o Padre Amaro a Amélia” (MELLO, 1911, p. 65). Mas, embora tenha visto o que ele considera "falha” durante a construção da narrativa, Mello ressalta a importância do livro na elaboração de um retrato do clero corrompido, ou melhor, “o estudo da dissolução do clero, pelo absurdo do celibato exigido de sacerdotes em promiscuidade com o mundo moderno, esse tema primordial da obra, é magnificamente tratado” (MELLO, 1911, p. 66).

Longe dos elogios desferidos às duas primeiras obras de Eça, Os Maias, segundo o crítico, só tivera destaque na elaboração de sua “interessantíssima galeria de caricaturas dos grandes homens encarregados da direção de Portugal” (MELLO, 1911, p. 73). Fora 
esse fato, que trazia o cenário cômico dos ministros, dos diretores de instrução pública, dos conselheiros e dos deputados, o livro, para Mello, era exagerado na descrição do meio português e

o fio que prende todas as cenas reveladoras da decadência dos homens públicos, o drama do personagem principal e sua amante, esse, melhor ficaria, de fato, num segundo plano, porque, isolado, desprendido de todos os acessórios que a mim se me figuram o encanto capital do livro, ele revelaria inúmeros defeitos (MELLO, 1911, p. 73-74).

Ademais, Mello acusa o livro de inverossimilhança, com base nas atitudes de alguns personagens. Por exemplo, quando ocorreu o “descaso” de Afonso da Maia sobre o nascimento da sua neta, julgando-a morta antes mesmo de realizar, efetivamente, uma busca por notícias concretas da existência da criança. Outro exemplo foi o total abandono de Monforte, que não procurou nem ver o filho Carlos.

Não obstante, fazendo justiça aos Maias, o crítico brasileiro defende algumas de suas construções textuais que revelam uma perfeição, "não conseguida por nenhuma outra obra de arte da literatura portuguesa” (MELLO, 1911, p. 79). Ele destaca três cenas: "a visita de Carlos a Maria Eduarda, na tarde de sua declaração de amor; à rua de S. Francisco: a ida de Castro Gomes ao Ramalhete; a subsequente entrevista de Carlos e Maria nos Olivais” (MELLO, 1911, p. 78-79). Verifica-se que a escolha de Mello não é casual e apresenta um único motivo: a dramaticidade.

Em relação aos livros da "Segunda Fase", Miguel Mello monta um quadro que pode ser compreendido da seguinte forma: A Relíquia (1887), como sendo um livro dividido em dois momentos: o primeiro, em que o escritor cria um sonho da reconstrução histórica da Galileia e da época da morte de Jesus; e, o segundo, em que o escritor faz uma sátira à vida devota. O Mandarim (1879), como sendo uma fábula sobre o dinheiro. $A$ Correspondência de Fradique Mendes (1900), centrado na construção da personagem 
Fradique como sendo "um tipo de homem moderno, superior pela elegância mundana e pela finíssima ironia” (MELLO, 1911, p. 83). A Ilustre Casa de Ramires (1900), como sendo um livro que faz parte daquela fase mais tranquila do escritor, em que ele revelara uma exaltação à pátria portuguesa quando, simbolicamente, construiria a Casa como metáfora de Portugal. A Cidade e as Serras (1901) como sendo um "hino de amor à terra portuguesa” (MELLO, 1911, p. 83).

Nota-se, na crítica de Mello, que, por mais que ele apresente a obra de Eça como realista, ele aponta para os textos queirosianos um fundo romântico que o escritor "não conseguiu jamais vencer” (MELLO, 1911, p. 84). E essa ideia ganha fôlego e passa a ser sustentada por queirosianos renomados do presente, que aceitam a presença da imagem fantasmagórica do Romantismo na obra de Eça de Queirós.

\section{$2.2 \mathrm{O}$ estudo da vida}

Mello inicia seu percurso biográfico com os “Primeiros tempos” de Eça enfatizando o fato de o pai do escritor ter nascido no Brasil na tentativa de estimular uma aproximação, além literatura, de Eça com o nosso país. Mello destaca, também, o fato de Eça só ter sido legitimado não no ano de seu nascimento, 25 de Novembro de 1845, mas alguns anos depois.

O crítico brasileiro retrata uma infância conturbada do escritor, dando indícios de quão solitário Eça ficara em seus primeiros anos de vida. Todavia, Mello, na aproximação que faz entre o autor e a cultura brasileira, ameniza essa solidão na figura da ama brasileira. Essa visão do Brasil como elemento acolhedor, durante a infância de Eça, será tema recorrente em críticas posteriores. 
Não se preocupando com o detalhamento na descrição da infância e da adolescência de Eça, o crítico dá um salto temporal e alcança 1861, época em que Eça matriculara-se na Universidade de Coimbra. Naquele momento, aponta Mello, o escritor, ainda um jovem estudante, possuía uma saúde frágil, um corpo franzino e uma grande timidez. O crítico faz referência a um Eça sem destaque durante a vida acadêmica, apontando diferenças com o companheiro Antero de Quental, “o grande poeta, temperamento nebuloso de eslavo, sentia-se estrangeiro com seu amor à Ideia pura [...]” (MELLO, 1911, p. 113-114).

Mello inaugura a imagem de Eça despercebido em Coimbra, distante da polêmica Questão Coimbrã. Nos próprios estudos acadêmicos, ele "não foi bom estudante, não era aplicado, e seu temperamento indolente, que depois lhe granjeou uma fama injusta de escritor de laboração difícil, comprazia-se em leituras dispersivas” (MELLO, 1911, p. 133).

De interessante nesse biografismo inicial sobre Eça elaborado por Mello são os bastidores. Mello se aprofunda mais na vida do autor e compreende que, mesmo em sua quietude, ele já iniciava, em 1866, no ano de sua formatura, os primeiros escritos de $O$ Crime do Padre Amaro sem ninguém desconfiar. Dessa forma, é possível notar na leitura biográfica de Mello uma preocupação não com o percurso descritivista da vida de Eça, no caso, em Coimbra, mas como, nesse momento, surge o escritor. Daqui por diante, Mello passa a descrever a vida de Eça “Da estreia à maturidade”.

Nesse segundo momento sobre a vida de Eça, Mello ressalta as "influências" recebidas pelo autor, a construção da carreira dele e as diferenças de concepção dos primeiros textos aos últimos do escritor português.

O brasileiro revela que, nos primeiros escritos, em forma de folhetim, na Gazeta de Portugal e na Revolução de Setembro, o autor desvendara as influências de Hugo, 
Baudelaire e Heine. Essas publicações de Eça causaram espanto, já que ele nunca demonstrara aptidão para as letras, conforme pontuara Teófilo Braga:

Parece uma alma que se achou desde criança hostilizada, e que se refugiou em si mesmo, como certas flores que fecham o cálix quando são tocadas. Foi assim que Eça de Queirós começou a escrever, sem que ninguém suspeitasse da veleidade literária; da sua geração acadêmica ninguém foi capaz de adivinhar que ele rabiscava papel e quando apareceu na imprensa jornalística, apresentou-se com um estilo definido, como quem estava adestrado nesse torneio de todos os dias; tinha o poder da linguagem (apud MELLO, 1911, p. 135).

Em Portugal, quando atacavam o estilo de alguém como sendo “coimbrão”, significava que a pessoa não escrevia de forma clara. Esse termo passou a ser usado pelos contrários a Antero de Quental, que achavam sua escrita confusa. Para Mello, por acharem a escrita de Eça extravagante, cunharam seu estilo também de “coimbrão”. Mello salienta o fato de até amigos de Eça acharem estranhos seus textos e traz uma observação de Teixeira de Vasconcelos, fundador da Gazeta de Portugal, sobre Eça: “Tem talento este rapaz, é pena ser completamente doido, ter estado em Coimbra, meter nos seus contos, sempre, dois cadáveres amando-se num banco do Rocio, e ... escrever francês!” (apud MELLO, 1911, p. 136).

Mello continua o percurso pela vida de Eça assinalando os momentos importantes que determinariam o escritor. Primeiro, ele salienta a viagem que o escritor fizera ao Oriente em 1869, que fora o pontapé inicial na construção do grande artista. Mello acredita nisso, porque observa que, após o retorno à Portugal, Eça iniciara uma forte amizade com Ramalho Ortigão e os dois passaram a frequentar, juntos, o Cenáculo ${ }^{57}$. Essas reuniões com os amigos favoreceram muitas discussões literárias, que, mais tarde, tornar-se-iam as

\footnotetext{
57 "Reunião de artistas e literatos, alguns dos quais trazem de Coimbra para Lisboa a boemia e a inquietação política e social que culminaria nas Conferências do Casino [...]” (MATOS, 1993, p. 192).
} 
Conferências do Casino $^{58}$, porque as palestras aconteciam no Casino no largo da Albegoaria. Mello descreve a função de Eça durante as Conferências da seguinte forma: “A Eça coube fazer uma conferência sobre o Realismo na Arte, onde vazou o seu entusiasmo por Proudhon, Stendhal, Balzac, e principalmente Flaubert, que se tornou o seu autor predileto” (MELLO, 1911, p. 146). Nesse trecho, verifica-se que Mello é sutil ao apontar os gostos do autor pelos escritores estrangeiros e ameniza a suposta ideia de Eça copiá-los. Embora o crítico brasileiro, não abandonando o argumento de que os textos do escritor português se aproximavam de outros textos, Mello concebe essa relação mais como “predileção” do que como cópia.

Em seguida, o crítico brasileiro passa a retratar o período em que Eça fora para Leiria como Administrador do Conselho da cidade, função que, em nada, agradara ao escritor e o que o levaria a iniciar os estudos para ingressar na carreira de cônsul. Mello destaca desse período a publicação de O Mistério da Estrada de Sintra (1871), em conjunto com Ramalho Ortigão. Conforme afirmara o próprio escritor, esse livro “é execrável; e nenhum de nós, quer como romancista, quer como crítico, deseja, nem ao seu pior inimigo, um livro igual. Porque nele há um pouco de tudo quanto um romancista lhe não deveria pôr e quase tudo quanto um crítico lhe deveria tirar” (apud MELLO, 1911, p. 149-150).

Para Mello, a vida de andarilho entre Havana (1872) e Newcastle (1874) rendera a Eça As Farpas e a primeira publicação de O Crime do Padre Amaro que

tinha sido preparado aos poucos, durante os anos de Coimbra, Évora e Leiria. Foi ultimado em 1871, lido a alguns amigos em 1872. Começou com cem páginas, tantas eram as de que constou o primeiro jato. A edição definitiva dá-lhe setecentas.

\footnotetext{
58 “Na origem destas Conferências, que devem o seu título ao fato de terem sido realizadas no Casino de Lisboa [...], está a influência decisiva de uma geração coimbrã que deu origem à Sociedade do Raio, à Rolinada e à Questão do Bom Senso e Bom Gosto” (MATOS, 1993, p. 172).
} 
Sepultado na Revista Ocidental que suspendera a publicação deixando-o em meio, ele passou despercebido. Em 1876 apareceu em livro a primeira edição, feita pelo próprio autor. Não despertou grande curiosidade (MELLO, 1911, p. 154).

Nesse trecho, nota-se que Mello cita brevemente o silêncio da crítica a respeito do Crime não se aprofundando nos motivos disso e destaca que, somente após a publicação de O Primo Basílio, o Crime receberia "alguma atenção da crítica”. O Primo, por sua vez, causara um alvoroço, tanto em Portugal quanto no Brasil e Mello explica tal fato na repercussão na imprensa com publicações de várias críticas ${ }^{59}$ nos dois países.

Para finalizar esse momento da vida de Eça, Mello resgata a publicação de mais três romances: O Mandarim, A Relíquia e Os Maias, dando destaque ao último:

Os Maias foram recebidos como um romance à clé. Imediatamente espalhou-se que João da Ega era o próprio autor. Em Carlos da Maia, haveria um ou outro traço do Conde de Resende. O Marquês era o Conde de Castelo Melhor, toureiro, sportman. Tomás de Alencar era Bulhão Pato, etc (MELLO, 1911, p. 181).

A partir desse trecho, nota-se que Mello lança suposições levantadas pelo públicoleitor da obra queirosiana referente à possibilidade de os personagens dos romances de Eça serem construídos com base em pessoas reais. Mas, em nenhum momento, o crítico coloca esse argumento como discurso dele, indicando imparcialidade sobre o assunto.

Por fim, Mello ingressa nos “Últimos tempos” de Eça demonstrando preocupação referente às mudanças que aconteceram na obra do escritor no fim de sua vida: de uma obra iniciada com um tom revolucionário e irônico para uma obra conservadora e conformista. Verifica-se, no estudo de Mello, que o que ele considera transformação na obra de Eça, seria resultado do próprio temperamento do escritor: se a “Primeira Fase” da obra queirosiana fora concebida como sendo mais agressiva, esse fato estava relacionado

\footnotetext{
${ }^{59}$ Cf. NASCIMENTO, José Leonardo. O Primo Basílio na imprensa brasileira do século XIX. São Paulo: Editora UNESP, 2008.
} 
diretamente às vivências de Eça naquele momento (revoltado com a instituição do casamento, com Portugal); e, se a "Segunda Fase” fora concebida como conservadora, era porque o autor estava mais sereno e em paz com tudo à sua volta.

No final de o Eça de Queiroz, Mello apresenta, em forma de anexo, alguns documentos que lhe foram úteis no momento de escrever sobre a vida e a obra do escritor português. Ao mesmo tempo em que sua crítica ficou enriquecida pela presença desses documentos dando legitimidade ao seu estudo, ela foi muito criticada pelo fato de Mello não ter ido a Portugal com o objetivo de verificar a fidedignidade das informações para construir sua crítica.

Mesmo recebendo críticas, o estudo de Miguel Mello é a matriz da crítica queirosiana em forma de livro no mundo e é importante lembrar que a sua crítica tem, no depoimento de José Maria Eça de Queirós, filho do escritor, uma de suas principais fontes interpretativas. Assim sendo possível dizer que a visão que Mello constrói da vida e da obra de Eça é pautada pelo questionário que este lhe respondeu: um Eça polêmico, revolucionário e crítico de Portugal na juventude, que, na maturidade, acaba os seus dias como um admirador da cultura portuguesa, reconciliado com o seu país e com a Igreja Católica. Entre outras, essa imagem da vida e da obra de Eça perdura nos manuais literários do Brasil e de Portugal até os nossos dias. Assim, valendo-se das palavras de Alfredo Campos Matos, Eça de Queiroz é um livro que, representa “um primeiro passo de assinável importância para a história dos estudos sobre E.Q.” (CAMPOS, 2000, p. 414), que abriu caminho para as publicações em formato de livro no país daí por diante. 


\section{Viana Moog: Eça, personagem}

Que prazer mergulhar no passado e ver aos poucos surgir uma vida, dentro de sua época, com as suas inquietações, as suas esperanças, os seus triunfos, malogros e decepções!

Viana Moog

De um modo geral, a crítica literária brasileira, a partir de 1930, foi muito produtiva, em consequência da industrialização que possibilitou a abertura a novos pensamentos filosóficos e artísticos, colaborando para o aumento da consciência crítica. Entretanto, apesar dessas mudanças, a crítica literária desse período retomou o gênero biográfico, que voltou com força e tradição, como aponta Luiz Viana Filho (1945):

Reabilitou-se. E, mais do que isso, de tal modo se alargou a significação da palavra "biografia" que acabou ganhando em amplitude o que perdeu em exatidão. Ora chamamos biografia a simples enumeração cronológica de fatos relativos à vida de alguém; ora usamos a mesma expressão para trabalhos de crítica nos quais a vida do biografado surge apenas incidentemente; ora a empregamos em relação a estudos históricos onde as informações sobre certa época se sobrepõem às que se referem ao próprio biografado; ora a emprestamos às chamadas biografias modernas ou romanceadas. $\mathrm{E}$ até obras em que a fantasia constitui o elemento essencial da narrativa aparecem com rótulo idêntico (VIANA FILHO, 1945, p. 11-12).

Nessa época, o saber literário estava em harmonia com o saber da história literária e conhecer um escritor era, consequentemente, saber em detalhes sua biografia e distinguir o que seria "verdade” do que seria “invenção”. Este foi o trajeto percorrido por Viana Moog (1906-1988), em seu livro Eça de Queiroz e o Século XIX (1938), uma obra que surgiu, de acordo com o próprio crítico, com o objetivo de apresentar o “verdadeiro” Eça de Queirós. A preocupação sobre o verídico era tanta que Moog esclarece, no "Prefácio” do seu livro, que a tentativa de seguir os passos reais do autor possibilitou a ele apresentar fotografias 
que tivessem um valor histórico e verídico de modo que oferecessem sustentação ao seu estudo.

\begin{abstract}
Neste livro vali-me com extrema moderação de todas essas concessões. Entretanto, o que nele vai referido, é rigorosamente histórico. Fiz o possível por que Eça surgisse aqui tal como existiu: exuberante de vida e de espírito. Contudo, para o caso de não o ter conseguido, anexei prudentemente uma boa cópia de fotografias. Talvez sejam a parte mais consistente do meu trabalho. De qualquer forma, isto agrada o leitor, aproveita ao editor e a mim não me prejudica [...] (MOOG, 1938, p. 7).
\end{abstract}

No trecho, nota-se que Moog, inicialmente, apresenta ao seu leitor suas estratégias na realização da biografia sobre Eça de Queirós. E como principal recurso comprobatório o crítico brasileiro apresenta as fotografias, como estratégia de dar legitimidade para que a sua revisão do passado de Eça fosse analisada como um documento histórico. Como a intenção do crítico era reviver os passos do autor português baseados em fatos reais, a fotografia, que naquela altura tinha mais do que hoje grande valor simbólico documental e, portanto, de verdade, surgia ali como prova de sua honestidade intelectual.

Todavia, naquela altura, a biografia estava muito mais próxima do romance do que da história, ${ }^{60}$ de modo que o estudo de Moog se tornou uma biografia romanceada. Embora o crítico tivesse afirmado, em seu "Prefácio”, que desejava mostrar o Eça como ele realmente fora, Moog se desprendendo dos fatos históricos, inicia a sua crítica voltada mais aos aspectos da narrativa: "Num dos primeiros dias de outubro de 1906, Póvoa da Varzim, contra os seus hábitos, amanheceu alvoroçada” (MOOG, 1939, p. 11). A impressão que se tem, ao iniciar a leitura do estudo de Moog, é de estar mais próximo ao romance do que a uma crítica biográfica, visto que estão presentes elementos da narrativa, tais como narrador, personagem, tempo e espaço.

A biografia romanceada usada por Moog passou também a ser conhecida como "biografia moderna” virando moda no mundo das letras naquele momento. Faz parte das

\footnotetext{
${ }^{60}$ Cf. MAUROIS, André. Aspects de la Biographie. Paris: Au Sans Pareil, 1928.
} 
estratégias de uma biografia eleger um sujeito privilegiado, cuja vida incite a curiosidade dos leitores. Miguel Mello e Viana Moog iniciaram a crítica queirosiana no Brasil com o intuito de reescrever a vida de Eça, mas foi Moog, segundo Alfredo Campos Mattos (2000), quem realizou, na época, o estudo mais completo da vida de Eça, embora haja controvérsia acerca dessa afirmação, como no caso de João Gaspar Simões, que não inseriu Moog no seu estudo de 1945, por considerar a biografia do brasileiro muito romanceada.

É compreensível que Gaspar Simões não tenha visto o livro de Moog com bons olhos, pois, ao contrário do crítico brasileiro, o crítico português se voltou totalmente ao trabalho histórico. Moog também o fez, porém buscou dar um toque pessoal ao seu estudo sobre Eça.

\subsection{A abordagem psicológica da infância de Eça}

À “Introdução” Moog deu o subtítulo “Bastardo”, o que remete às condições peculiares do nascimento do escritor português, já comentada por Mello. O crítico brasileiro retrata esse momento colocando de pano de fundo uma encenação dramática entre as cidades Póvoa do Varzim e Vila do Conde lutando pela legitimidade do local onde Eça teria nascido.

Póvoa do Varzim passou alguns dias aniquilada. Não se deu, entretanto, por vencida. Depois de lida e relida, discutida e comentada a insólita proclamação, descobriram os poveiros, com rara argúcia, que o documento em que a mesma se baseava não indicava o lugar de nascimento, mas tão somente a sua data: 25 de novembro de 1845. Póvoa do Varzim respirou, aliviada. E tratou imediatamente de reunir uma prova esmagadora contra as pretensões da insolente adversária (MOOG, 1938, p. 12).

Moog instrumentaliza a figura de linguagem prosopopeia para personificar as cidades dando-lhes características humanas, como se as cidades brigassem, e não a sua 
população. Partindo dessa quimera entre vilas, Moog levanta uma questão significativa: quem foi realmente Eça de Queirós? Para o crítico, um homem rodeado de segredos, que passariam a ser desvendados por esse pontapé inicial sobre o mistério de seu nascimento.

\begin{abstract}
A partir, contudo, da publicação do escandaloso inquérito de Póvoa do Varzim, já não era possível manter o mesmo silêncio. Os biógrafos de Eça, quase todos seus amigos, compreenderam que tinham de mudar de atitude. Em face da revelação de suas origens, não podiam continuar secos e frios, contrafeitos e monossilábicos, como até então. Daí por que, timidamente embora, não tardaram a aparecer algumas das circunstâncias que precederam e sucederam o seu nascimento. Por elas ficou-se então sabendo que o romance de amor entre o Dr. José Maria e D. Carolina começara em Viana do Castelo, ao tempo em que aquele exercia as funções de delegado em Ponte de Lima. Este romance teve de ser interrompido em virtude das tremendas represálias dos setembristas contra os cabralistas, que obrigaram o filho do conspirador de Aveiro a andar foragido por algum tempo. Pouco depois, D. Carolina partiu para Póvoa do Varzim afim de que se mantivesse incógnita a sua gravidez. Aí nasceu-lhe José Maria, o filho de um momento arrebatado de amor, entre as vicissitudes daqueles escuros tempos. De Póvoa do Varzim a criança é conduzida para Vila do Conde, com apenas seis dias de idade, em pleno rigor do inverno, onde fica entregue aos cuidados da ama, "uma mulher do povo", indo depois para a companhia dos avós paternos, na casa de Verdemilho (MOOG, 1938, p. 16-17).
\end{abstract}

Apesar de Moog ter escolhido o forte subtítulo "Bastardo" para descrever os primeiros anos de vida de Eça, o crítico não trata o assunto de forma sensacionalista. Pelo contrário, tenta amenizar o que seria escândalo para a época - o nascimento de uma criança fora de uma relação formalizada perante Deus e a justiça - como resultado de um ato de amor. Também revela que o escritor tivera seus primeiros cuidados oferecidos por "uma mulher do povo”, o que pode ser entendido como uma intenção do crítico em aproximar Eça da realidade social de Portugal.

A vida de Eça, como pondera Moog, passara a ser desvendada, a partir da descoberta do local de seu nascimento. Depois, seguiram-se descobertas da linhagem paterna e, principalmente, da linhagem materna, até então, desconhecida. A respeito disso, verifica-se que a forma como foi concebida a biografia de Eça por Moog tem-se a nítida 
impressão de estar lendo uma história sobre cavaleiros medievais ao estilo romântico: em dado momento, o avô de Eça, Joaquim José de Queirós e Almeida, foi descrito como grande aventureiro; em outra, o pai de Eça, José Maria de Almeida Teixeira de Queirós, como o guerreiro e defensor da força da lei; e, por fim, a mãe de Eça surge envolta em mistérios. Dessa forma, pode-se concluir que, para Moog, Eça é tão especial e só poderia ter saído dos manuscritos medievais como herói misterioso e problemático, lutando contra a sua posição de bastardo.

Moog destaca a infância de Eça causadora de uma obra construída a partir de mágoa e de revolta, por isso, talvez, a ausência do retrato dos primeiros anos de vida do autor em sua produção.

Tem-se a impressão de que todas as recordações que lhe vem desse tempo estão ligadas a uma lembrança má que o aflige e que ele faz o possível por esquecer. Porque, evidentemente, não é crível que este invulgar memorialista se tenha deslembrado por completo das emoções de um período em que elas se gravam com mais nitidez na memória (MOOG, 1938, p. 19-20).

E como um bom biógrafo que era, como o próprio Moog anunciou, o dever dele era “aproveitar-se o mais possível dos sinais certos e inequívocos sobre determinada existência para a explicação de tudo quanto lhe parecer obscuro na psicologia do biografado" (MOOG, 1938, p. 20). Nessa afirmação de Moog, encontra-se uma fundamentação freudiana sobre a interpretação da infância de Eça. Compreende-se, nesse viés, que o crítico brasileiro se aproxima de Charles Baudouin (1929) e Gastón Bachelard (1937), que defendiam a hipótese de que a fantasia criadora esconde recalques guardados no subconsciente, ou, em outras palavras, Moog entende que a obra de Eça fora fruto de sua vida subjetiva, embora exista um vácuo nesse retorno ao passado causado, provavelmente, por um bloqueio psíquico. 


\subsection{A formação de Eça}

Em uma análise psicológica da obra de Eça, Moog retoma a timidez, a languidez e o aspecto físico enfraquecido do autor para mostrar como ele se fechara devido, principalmente, à infância solitária e como isso teria marcado a passagem do escritor pela Universidade de Coimbra:

No ano de 1861, tudo se passou como nos anos anteriores. Com uma pequena diferença: entre os recém-chegados encontra-se um jovem de dezesseis anos. Magro, franzino, encolhido, ligeiramente curvado, denota, pela palidez, não gozar de uma saúde perfeita. Sua aparência é de pessoa nervosa e impressionável. "Parece uma alma que se achou desde criança hostilizada e que se refugiou em si mesma, como estas flores que fecham o cálice quando são tocadas”. Chama-se José Maria Eça de Queirós (MOOG, 1938, p. 23-24).

Observa-se, nesse trecho, que mais uma vez Moog aproxima o discurso crítico do discurso narrativo durante a descrição de Eça ao apresentá-lo, mediante um tom poético, como se fosse um personagem literário partindo de recursos estilísticos.

Moog afirma que Eça não encontrava em Coimbra as grandes discussões literárias, artísticas e filosóficas que almejava. Na realidade, o que passava a interessar ao escritor português eram as tertúlias ${ }^{61}$. São nelas que Eça seguia um caminho inovador, juntamente com seus companheiros, que

inflamavam-se com as recentes revelações, inundavam-se de novas concepções. De resto, não podia haver mais propício ambiente para o surto dos novos sistemas, do que as suas repúblicas, onde uma mocidade, estuante de vida, celebrava em êxtase, o advento da nova era. Jovens, muito nervo para vibrar, muita alma para sentir, o cérebro escaldando na paixão das ideias novas, não havia colher as velas aos seus arrebatamentos (MOOG, 1938, p. 62).

\footnotetext{
${ }^{61}$ Reuniões em casa de amigos, onde eram discutidos assuntos como arte, religião, filosofia, música, história, literatura e atualidade.
} 
Para Moog e, mais tarde, para outros estudiosos queirosianos, Eça não tivera uma participação ativa nesse movimento transformador nas letras portuguesas, mas, mesmo assim, salienta que teria sido em "Coimbra que fez o aprendizado fecundo das ideias. Com a geração que encontrou é que se pôs em ligação com o século XIX. Ali aprendeu a arte do sarcasmo e do epigrama, e ria à maneira de Juvenal e de Rabelais: ruidosamente, implacavelmente” (MOOG, 1938, p. 76).

Além disso, Moog destaca que Eça surpreendera a todos, pois do silêncio durante a Questão, fora o único que realmente soubera praticá-la visto que "toda a sua obra demonstraria que foi nela que plasmou o melhor de sua mentalidade. Ela é que lhe fecundou a inteligência com as suas ideias fundamentais” (MOOG, 1938, p. 78).

Viana Moog percorre a vida do escritor português e na trajetória é possível conferir a predileção por seis momentos da vida de Eça, que o brasileiro considera cruciais para a formação do escritor: o primeiro foi a passagem de Eça por Évora e por seu bisemanário oposicionista Distrito de Évora, pois foi ali, de acordo com Moog, que Eça se dedicara exclusivamente à escrita, ao compor todo o jornal; o segundo momento surgiu por meio da desilusão que Eça teve com o jornalismo e o retorno às discussões literárias no Cenáculo; o terceiro foi a viagem ao Oriente, uma vez que, com essa nova experiência, Eça passara a ver o mundo de forma diferente; o quarto instante fora em Leira, pois, enquanto estudava para tornar-se cônsul, o autor iniciara a sua escrita de O Crime do Padre Amaro, além de ajudar Ramalho Ortigão a escrever O Mistério da Estrada de Sintra e a colaborar com As Farpas; o quinto período fora o encontro com os amigos Antero de Quental e Batalha Reis que originara as Conferências do Casino, e o sexto e último, a vida diplomática de Eça que proporcionara ao autor novas vivências e experiências adquiridas em outras localidades (Havana, Nova York, Newcastle-on-Tyne, Paris) uma fonte considerável de referências literárias, ideias e o retorno ao jornalismo. 
O escritor, de acordo com Moog, conseguira como ninguém, “reerguer Portugal da apatia e incorporá-lo ao movimento do século XIX” (MOOG, 1938, p. 78). Para o crítico, a obra de Eça fora a que soubera melhor repercutir os acontecimentos e as ideias do século XIX.

No conjunto de sua obra viveria somente o século XIX, nos seus aspectos predominantes, nos seus defeitos, como nas suas virtudes, e até nos seus transitórios desfalecimentos. Do século XIX vir-lhe-ia o cientificismo, o naturalismo, a irreligiosidade, o gosto pelos problemas psicológicos e sociais. Dele o narcisismo, o orgulho da razão, o materialismo, a suficiência, a fatuidade, o cinismo, o satanismo, a leviandade, a ligeireza, a procura desesperada de originalidade, a falta de originalidade, a arrogância, a paixão pelo bizarro, o dandismo, e no seu ocaso o grande desencanto do fim (MOOG, 1938, p. 80).

Esse trecho, certamente, pode ser considerado um resumo do estudo de Moog quando no título ele propôs resgatar a figura do autor em sua época. Para Alfredo Campos Matos essa tarefa não foi atingida plenamente, porque, segundo o estudioso português, "será porventura excessiva neste trabalho a sugestão que inculca o título de uma análise de Eça no seu século” (MATOS, 2000, p. 416). Todavia, Matos destaca positivamente o estudo biográfico empreendido por Moog em uma época que marcou o início dos estudos queirosianos.

Corrobora-se, neste estudo, a opinião de Campos Matos de que o livro do brasileiro marca os estudos queirosianos de maneira benéfica, mas é importante salientar que o próprio Viana Moog publicou uma antologia com um título semelhante com o texto anterior Eça de Queiroz. Homens e Ideias do século XIX, de 1942, no qual reviu e reformulou algumas hipóteses do estudo de 1938. Assim, mediante a observância de seus próprios equívocos da primeira publicação sobre o escritor português, Moog desenvolveu um texto mais conciso na defesa do argumento de que Eça soubera como ninguém viver sua época. 


\subsection{A autobiografia de Eça}

Fazendo uma releitura do estudo de Miguel Mello, Viana Moog recorre ao caráter divisório da obra queirosiana, notando que a mudança na vida do escritor fora responsável

pela metamorfose na obra, dando a esta última um novo rosto. À vista disso, ele aponta além da infância como elemento determinante de modificações na obra, sobretudo, o casamento que teria levado o autor rever a realidade.

\section{VIDA E OBRA}

$\begin{array}{ccc}\begin{array}{cc}\mathbf{1}^{\mathbf{a}} \text {. Fase } \\ \text { Revolta }\end{array} & \rightarrow & \mathbf{2}^{\mathbf{a}} \text {. Fase } \\ \text { (Infância - Sociedade) } & & \text { Ternura } \\ \end{array}$

Por meio desse esquema, nota-se que Moog coloca a vida pessoal e subjetiva de Eça em primeiro plano orientando a produção escrita e, vai mais longe, ao afirmar que devido a essa aproximação entre vida e obra, o escritor teria realizado uma produção autobiográfica.

Viana Moog, ao escrever a vida e obra de Eça de Queirós de forma romanceada por intermédio de documentação, dando legitimidade histórica ao seu estudo, centra-se no argumento de que a obra do escritor era um todo autobiográfico, uma vez que a vida de Eça fora o grande pano de fundo para que ele interpretasse sua obra escrita. Além do mais, Moog usa o fato de Eça ser filho bastardo de pais legítimos para realizar uma interpretação psicológica da obra queirosiana, procurando justificar a visão que Eça tinha da sociedade e, principalmente, das mulheres. Em consonância a isso, o crítico estabelece dois momentos psicológicos da vida do autor: um em que Eça traria para a sua obra os sentimentos de revolta e vingança por se sentir abandonado e sozinho; e outro em que Eça encontraria a 
paz após o casamento, conseguindo, finalmente, o equilíbrio e a serenidade transmitidos em seus últimos romances.

Nota-se que a crítica de Viana Moog transita por diferentes correntes críticas em voga na época (impressionista, histórico-literária, psicológica e, sobretudo, biográfica) para dar conta do título de seu estudo Eça de Queiroz e o Século XIX. Entretanto, observa-se que ele se afasta do título sugerido ao desconsiderar a obra de Eça como expressão de um momento peculiar da história de Portugal, marcado pelas tensões advindas da crescente internacionalização do capitalismo e dos diversos movimentos de resistência (comunismo, socialismo, anarquismo etc.), aos quais, por sinal, Eça esteve sempre atendo. À medida que focalizava a psique e a construção identitária do autor por um viés preferencialmente pessoal, Moog perde de vista esse contexto mais amplo que está anunciado em seu título e, em alguma medida, acaba reproduzindo uma leitura do conjunto da obra do escritor que já se encontra delineada em Mello. 


\section{4 Álvaro Lins: Eça, artista}

A impressão mais nítida que fica do conhecimento de Eça de Queirós é a de um homem no turbilhão: um homem que se debate no tumulto da riqueza episódica do século XIX, com a sua existência quase sem história, ao lado de uma grande vida dentro da literatura.

Álvaro Lins

Na década de 30, surgiu Álvaro Lins (1912-1970) na crítica literária brasileira, oriundo das páginas do Correio da Manhã, do Rio de Janeiro. Considerado um crítico profissional, isto é, atuante e não circunstancial, o seu surgimento na crítica, nas palavras de Adélia de Meneses, foi um "fenômeno histórico: numa determinada sociedade, o terreno se acha propício, e esse tipo de crítico tem vez” (MENESES, 1979, p. 18). Ademais, Lins conciliou a vocação crítica com outros ofícios: de jornalista, de político e de professor.

Ele defendia uma crítica interpretativa e apreciativa, de viés impressionista, o que possibilitou a presença da linhagem subjetiva em grande parte de sua produção crítica. Lins foi subjetivo não somente pelo fato de a crítica impressionista restringir-se à notação das impressões que a obra instigava na leitura, mas, e principalmente, pelo fato de rejeitar o padrão rígido estruturalista, que, então, começava a se delinear.

Álvaro Lins destacou-se na crítica jornalística, na qual foram concebidas as suas mais variadas críticas. Além disso, em sua vasta produção como crítico, estão inseridos dois livros denominados História literária de Eça de Queiroz (1939) e A técnica do romance em Marcel Proust (1951).

Dando continuidade aos passos tomados pela tríade - Sílvio Romero, José Veríssimo e Araripe Júnior - Lins exerceu a tarefa de analisar e de julgar, com seriedade, 
obras e escritores diversos, visando a contribuir para a vida literária brasileira. Para ele, a interpretação da literatura deveria ser entendida como fonte criadora, pois ela "é a compreensão, é a penetração, é a análise, é a reconstituição, é a revelação, é o sentido psicológico, é o poder sugestivo, é o jogo e o debate das ideias” (LINS, 1963, p. 376).

Para Lins, adepto do pensamento de Bérgson, a crítica é uma arte literária, uma vez que ela exige do crítico um conhecimento aguçado dos juízos de valor. E é dentro dessa perspectiva impressionista que Álvaro Lins percorreu a obra de Eça de Queirós em seu estudo.

Embora Lins faça parte da crítica que defendia o valor das sensações que o texto literário proporcionava ao leitor, tenta ressaltar, no “Prefácio”, o caráter histórico e analítico com que se debruçava sobre a obra do escritor português, como é possível notar no trecho a seguir:

Da vida de Eça de Queirós, muito conhecida através de duas ou três excelentes biografias, este livro refere bem pouco porque visa outro fim. O que ele pretende é transmitir a posição intelectual de Eça em face das gerações mais novas, daquelas que não o conheceram nem sentiram a sua influência (LINS, 1939, p. 7).

Todavia, mesmo focalizando a obra, Lins não abandona a vida do autor. Embora o seu estudo não possa ser considerado uma biografia, pelo fato de não apresentar como ponto crucial o estudo sobre a vida do autor e sim o que Eça transmitira na sua produção.

Verifica-se que foi difícil para Lins separar a vida da obra e vice-versa, pois, para ele, Eça tivera uma vida plenamente voltada à literatura e fora da literatura que o escritor português fez a vida, corroborando concepções de Mello e Moog. E apesar de carregar no título História Literária, o livro de Lins traz como centro de discussão, por um viés de uma linhagem impressionista, como Eça fora construído na mescla do homem com o artista. A respeito disso, de acordo com Lins: “A sua biografia é a história do conflito que o explica: 
conflito entre o artista e o homem. O artista que procurava ultrapassar o tempo e a época, o homem que tendia a ligar-se aos problemas do seu século [...]” (LINS, 1939, p. 16). Assim, compreende-se que o crítico brasileiro entende que o romance queirosiano posicionara-se tanto como uma obra literária quanto como um documento humano e social de seu país e de sua época. Nesse ponto, observa-se que Lins concebe a imortalidade da obra queirosiana diferentemente de Moog, que destacou a imortalidade da imagem de Eça, especialmente quando cita a estátua do escritor como forma de homenagem. Lins não esconde o fato de que a vida e a obra de Eça estão entrelaçadas, porém, mesmo assim, busca investigar não a biografia do autor, mas a vida literária de um escritor que, segundo ele, não sucumbira com o tempo.

No estudo histórico-biográfico de Lins, a vida do escritor português não está disposta em ordem com datas e acontecimentos, contudo, o crítico inicia seu percurso afirmando, já de imediato, que o Eça artista sobrepôs o Eça socialista, o Eça político e o Eça homem. Em consonância com esse argumento, o próprio Lins ressalta no conflito entre o homem e o artista que a vitória fora da "arte contra o temperamento" (LINS, 1939, p. 17). E pensando Eça dessa forma, ele dá continuidade à visão do escritor talentoso e sem ideias que dominou os estudos de Miguel Mello e Viana Moog.

\subsection{Formação inicial de Eça de Queirós}

Na análise do conflito entre o homem e o artista, Álvaro Lins observa, primeiro, o posicionamento de Eça na geração coimbrã de 1865:

A posição de Eça de Queirós em face de Portugal e do mundo participa, em grande parte, da posição coletiva dos companheiros da sua idade. Dos companheiros da chamada geração de 1865 [...] 
Quando esta geração apareceu em Coimbra, a decadência de Portugal tinha se tornado um acontecimento irremediável. Não era mais uma decadência só pressentida pelos filósofos, pelos historiadores, pelos críticos. Era uma cena espetacular entrando pelos olhos mais distraídos ou mais sonhadores.

A decepção para os jovens de 1865 deve ter sido tremenda. Porque não há nada de mais triste do que a decadência: é mais triste do que a morte. [...]

Diante da decadência, nenhuma atitude de meio termo seria possível, tornava-se preciso escolher entre a conformidade que era a morte, e a luta, que era a vida. É uma circunstância que explica este paradoxo de céticos, à maneira de Eça, que se dedicam todos ao combate afirmativo e quase heroico (MOOG, 1938, p. 23-24).

Álvaro Lins, nessa breve apresentação da Geração de 1865, posiciona Eça em um momento politicamente conflituoso em Portugal, fato que o crítico aponta como elemento fundador da carreira artística de Eça, isto é, nas palavras de Lins Eça vivera

uma vida alheia à ação e só vendo no mundo um instrumento de criação artística. Diz-se ação aqui no seu sentido mais comum, a dos movimentos pelas realizações imediatas e utilitárias. Porque num aspecto mais amplo também Eça amou a ação. Apenas concentrou todas as suas ambições na ação intelectual, no desejo de criar uma obra e se continuar com ela (LINS, 1939, p. 35).

Dessa forma, o que Lins apresenta é um Eça distante das agitações político partidárias, voltado ao mundo das ideias e mergulhado no mundo intelectual, ainda confuso, “em procura do seu caminho verdadeiro” (LINS, 1939, p. 35).

Álvaro Lins sustenta uma posição contra qualquer tipo de divisão da obra do artista em fases ou classificações, entretanto, a obra poderia ser interpretada "por uma circunstância que é comum e inevitável: a idade” (LINS, 1939, p. 48). Assim, para o crítico, se houvesse algum tipo de separação da obra queirosiana, que ela fosse feita através da idade e o que viesse fora disso atuaria "mais como excitantes" (LINS, 1939, p. 49). Em outros termos, Lins defende a hipótese de que a obra de Eça fora construída seguindo as etapas da vida: da juventude surgiu o panfletário; da fase adulta, tem-se o irônico e, 
finalmente, da fase madura, o conformista. Ecoando Mello e Moog, para Lins há uma harmonia entre a atitude literária de Eça e a vida.

\subsection{A construção romanesca}

Na opinião de Lins, a “obediência” ao Realismo fez com que Eça, em muitos momentos, como em O Crime do Padre Amaro e O Primo Basílio, abdicasse do seu temperamento sentimental para aceitar os limites da escola realista, que surgira, para ele, como forma de amenizar esse sentimentalismo exagerado romântico e de favorecer o estabelecimento de um equilíbrio interior. Portanto, o Realismo de Eça é entendido pelo crítico como uma recriação do real.

É um fenômeno que todos conhecemos: costumes, paisagens, figuras humanas, que estão diante dos nossos olhos, despercebidos e até insuspeitados, adquirem, de repente, forma e movimento através da arte. É que o artista, somente ele, tem o privilégio de ver, na natureza e na humanidade, de ver e de revelar, aspectos, sentimentos, perspectivas, todo um outro mundo desconhecido para os outros homens (LINS, 1939, p. 84).

Para Álvaro Lins, o percurso mimético empreendido por Eça na construção dos romances não tira de sua produção o fio imagético responsável pela recriação do real, ou valendo-se das próprias palavras do crítico: “toda a sua obra romanesca se formará dos três elementos essenciais: sonho, observação e intuição psicológica. A fusão do sonho com a realidade num temperamento de artista” (LINS, 1939, p. 87). Lins parte do pressuposto de que a realidade é para todos a mesma, mas só quem tem um espírito artístico consegue recriá-la de forma ficcional. Esse era o caso de Eça.

O público, no entanto, nem sempre teria entendido sua obra. Como foi observado, Eça ficou inconformado com a pífia recepção da crítica e do público em relação ao Crime, 
o que para o Lins “era, antes, a perplexidade diante de uma surpresa de proporções tão imprevistas” (LINS, 1939, p. 91). Os leitores não teriam percebido que a crítica de Eça, partindo do personagem Amaro, não era contra a Igreja, mas contra o poder de manipulação do pensamento que a religião tinha naquela época. Essa visão de Lins vem na contramão do senso comum da crítica queirosiana uma vez que, nessa altura, já era aceita e difundida a ideia de que esse romance apresentava como tese a crítica à Igreja Católica. Tanto é que Lins salienta a falta de tese no Crime, argumentando que "Eça procurou, foi muito mais a verdade da arte do que a verdade da vida e que não sacrificou a literatura a nenhuma das suas paixões ou raivas de momento” (LINS, 1939, p. 101). Ainda conforme o crítico brasileiro:

Tivesse Eça mostrado um padre por vocação, consciente da sua missão, debatendo-se, depois, na impossibilidade do celibato, vencido pela carne e fechado à graça de Deus, então sim o livro como tese, teria atingido o seu fim. O romance, porém, é que perderia a lógica e a verdade, porque, sabe-se muito bem, para o verdadeiro padre, o celibato é uma condição normal (LINS, 1939, p. 103).

Dando prosseguimento ao seu argumento, Lins ressalta que, ao construir um padre sem vocação, Eça não estava desonrando a figura do padre, mas "desonrou-o para salvar em si mesmo, o seu caráter de romancista” (LINS, 1939, p. 103). Em vista disso, Álvaro Lins defende o Crime contra "julgamentos injustos ou pouco inteligentes” (LINS, 1939, p. 104) e apresenta outra perspectiva do romance que, com "exceção de alguns detalhes, o Crime do Padre Amaro é a expressão artística de uma realidade que a história confirma. Por isso pareceu e serviu, no seu tempo, como um livro de combate. Hoje, não é mais. É uma obra de arte, com um sentido histórico” (LINS, 1939, p. 104-105).

Assim, para Lins, principalmente no diálogo entre Amaro e Ferrão, Eça conseguira transmitir o seu pensamento e sua preocupação em dominar a arte. Em consonância com isso, de acordo com Carlos Reis, “Álvaro Lins revela uma consciência muito esclarecida 
(e, muito atual, diga-se de passagem) de como o romance foi uma solução de gênero (literário) arduamente perseguida e mesmo aprendida” (REIS, 2000, p. 31-32) para Eça.

Álvaro Lins mantém sua perspectiva crítica ao analisar O Primo Basílio afirmando que ali Eça se utilizara dos mesmos recursos técnicos, no entanto, mais aprimorado. Todavia, o crítico brasileiro, fazendo uma leitura comparativa entre o Crime e o Primo, defende a ideia de que o segundo romance fora a continuação do primeiro "nos princípios estéticos e morais, na linguagem, no estilo, continua até mesmo na simplicidade arrogante com que ambos revelam a sua origem: o Naturalismo francês” (LINS, 1939, p. 108). Nesse trecho, verifica-se como Lins dá continuidade à crítica de Machado de Assis no julgamento de que $O$ Primo Basílio é um romance naturalista, porque segue a linha de Taine. Isso está bem posto no seguinte trecho: “O pequeno círculo humano, do qual Basílio é uma flor de patifaria, tem uma localização muito menor e, ao mesmo tempo, muito mais larga; ele se integra no ambiente incaracterístico e internacionalizado da burguesia” (LINS, 1939, p. 109).

Dessa forma, Lins conclui que no Primo, em uma ação antirromântica (não dando poeticidade ao adultério), não existem culpados e pecadores, mas o que “determinou” o desenrolar da história fora a educação dada aos jovens daquele período e, especialmente, à sociedade, que tolerava as ações deles. Lins condena a crítica de Machado, por considerar que este "levava ao máximo a sua exigência, usando de um critério que nenhum crítico pode usar, o de imaginar, para os personagens alheios, destinos diferentes” (LINS, 1939, p. 112). Ao se contrapor a Machado, considera o imprevisto como elemento crucial para o andamento da narrativa, isto é, o imprevisto da gravidez de Amélia e o imprevisto da carta de Juliana. 
No Primo, conforme Lins, Eça não iria punir Luísa com a morte. Viu tal desfecho como um recurso romanesco: não teria um outro fim para Luisa, a não ser a morte. De acordo com o crítico brasileiro,

a morte de Luisa realiza-se, então, como uma necessidade da arte do romance e não como uma solução moral, como infantil castigo. Trata-se de uma lógica não só humana mas também de uma lógica, digamos, ideal ou artística (LINS, 1939, p. 115).

Logo, Álvaro Lins defende o argumento que o Primo representa um "efeito romântico pelo avesso” (LINS, 1939, p. 117), principalmente nas cenas entre Luisa e Juliana, que, para o crítico, eram de extrema dramaticidade. Nesse drama e na independência dos personagens, Lins vê, nesse romance, um Eça capaz de observar a realidade sem se sensibilizar com ela, ou nas palavras do crítico, ele foi “desumanizado pela arte” (LINS, 1939, p. 118).

Álvaro Lins afirma que Os Maias retomara o estilo de Eça permeado pelo humor. O efeito cômico que o crítico brasileiro observa no romance era o seu grande destaque; contudo, ele também argumenta que era um romance que parecia um retrato incompleto do ponto de vista aristotélico. Mesmo revelando essa fragmentação, que, para Lins, era negativa, insistiu na escolha de Os Maias como o grande romance de Eça.

Notando o gosto do autor pela fantasia, explica a existência de textos como $O$ Mandarim e A Relíquia, que se apóiam na realidade para mostrar "seus devaneios mais libertários” (Lins, 1939, p. 128). Desses livros, Lins destaca A Relíquia e a sua recepção na crítica que, em geral, fora positiva, com exceção daquela de Pinheiro Chagas, que, ao escolher a cena do sonho de Teodorico, condenou-a sumariamente: “a impossibilidade do sonho em face das condições pessoais do personagem” (LINS, 1939, p. 133). Esse argumento perpassara o tempo e Lins se sentia na obrigação de revisá-lo, pois, como ele próprio afirma “já é tempo de tentar, com os novos elementos de hoje, uma revisão nesta 
impossibilidade não só psicológica mas literária que Pinheiro Chagas afirmou para o sonho da Relíquia” (LINS, 1939, p. 134).

Lins não aceitava a hipótese de Pinheiro Chagas de que o personagem Teodorico fosse tratado como um "pateta” e um “devasso” que não teria como repertório intelectual para sonhar com o episódio da Paixão de Cristo. Nesse ponto, Lins ressalta que Chagas usara um método crítico inadequado, pois ele portara-se "como um crítico realista”, enquanto Eça estava “no domínio da fantasia” (LINS, 1939, p. 139). Isto é, Lins resume o assunto afirmando que Pinheiro Chagas ficara estarrecido com “o controle entre o indivíduo que sonhou e o sonho que lhe é atribuído” (LINS, 1939, p. 143-144), e que ele não conseguira perceber que o sonho de Teodorico fora o resultado da formação inicial do personagem, voltada aos preceitos religiosos, em outras palavras, o que Lins defende é um sonho criado por uma pessoa com uma forte educação religiosa que mais tarde se tornara um capitalista e que, ao transitar por estes dois universos díspares, sonha o que sua vivência propicia.

\subsection{A centralidade dos personagens}

Lins destaca a força criadora dos personagens de Eça que superaram o tempo e atingem outras gerações afirmando que "realizam sozinhas sua trajetória dispensando qualquer interpretação” (LINS, 1939, p. 229). Isso se daria porque Eça construiria personagens de fácil entendimento, principalmente pelo fato de não se aprofundar no íntimo deles. “Eça nunca perscrutou o ‘mistério’ dos personagens como nunca se deteve em interrogações muito demoradas diante da vida” (LINS, 1939, p. 230). A respeito dessa característica Lins considera Eça um naturalista no sentido literário e metafísico, pois o autor centrara-se nas descrições físicas dos personagens, o que resultara em um traço 
“objetivo, superficial e plástico” (LINS, 1939, p. 230). A construção dos personagens queirosianos giraria em torno de sua ação e da relação entre eles e o escritor: “o privilégio de amar e odiar personagens, de se apaixonar a favor ou contra, mas com um sentimento de artista que não tem nada que ver com os sentimentos da outra vida, da vida de todos os dias” (LINS, 1939, p. 233-234). O crítico enfatiza que, na humanidade dos personagens, Eça apresentara uma característica predominante: a memória.

Eça evoca o passado dos seus personagens, reconstitui-o ao lado do presente, para mostrar as marcas e as fixações que os momentos vão deixando nas almas. Que vão desenvolvendo os destinos sem que, muitas vezes, as almas sintam que estão marcadas (LINS, 1939, p. 237).

Segundo o crítico, Eça se posicionara diante da vida por meio de seus personagens, isto é, como se o autor virasse "um espectador”, “alguém que olha, que tira conclusões, que ri do espetáculo, que aparece, por esnobismo ou por amizade, no meio dos atores, mas que só quer uma cadeira do lado de fora” (LINS, 1939, p. 243). E para dar conta da transposição do real para o ficcional, Lins ressalta mais uma vez o estilo de Eça:

Dominar as palavras, para expressão das ideias ou da imaginação, no seu sentido pessoal, sem se isolar, e no sentido geral da "correspondência" com o público, sem se vulgarizar, parece que foi o grande ideal artístico de Eça de Queirós. E diante dele, como o elemento mais simples do problema artístico, colocou-se a língua que seria o seu instrumento verbal (LINS, 1939, p. 247-248).

Em vista disso, para Eça revelar as verdades humanas seria necessário uma inovação literária, uma reforma da língua portuguesa, lutando para que as palavras fossem livres e se soltassem da "sintaxe apertada em regras invioláveis, as palavras muito sovadas pelo mesmo uso excessivo, os substantivos unidos com os adjetivos sempre da mesma maneira como casais sem filhos” (LINS, 1939, p. 249). Para Lins, Eça sabia que o único 
meio de ele ser lembrado nas próximas gerações, de ser imortalizado seria por meio da linguagem, “marca da sua nobreza e da sua ascensão” (LINS, 1939, p. 263).

\subsection{Eça e a política}

Eça descreveria o mundo de uma perspectiva ampla, pois, nas palavras do crítico, “[Eça] compreendeu que não pode existir uma literatura de partido, de classe, de regime; que a literatura será expressão da vida, mas nunca das suas divisões, no serviço mesquinho da direita ou da esquerda, dos grupos ou das ideologias” (LINS, 1939, p. 299-300). Lins identifica uma relação harmônica entre o que é humano e o que é artístico na obra de Eça, revelando que o seu socialismo "foi muito mais um sentimento do que uma ideia” (LINS, 1939, p. 288).

Exprimindo artisticamente a vida, Eça também exprime as contradições que ela contém. Atraiu para si mesmo, por isso, a acusação que devia cair sobre os fatos. É que ele não era um filósofo ou um doutrinário mas um artista. Manteve sempre, no entanto, do seu ponto de vista pessoal, atitudes harmônicas e coerentes. O que não ficou foi imutável em algumas ideias fixas que o tornariam louco, no tumulto episódico e ideológico do século XIX (LINS, 1939, p. 281).

A partir desse trecho, verifica-se que Álvaro Lins defende essencialmente um Eça artista, afastando-o do universo político. O crítico divide a obra de Eça, do ponto de vista político-social, em dois momentos: “na mocidade é a crítica feroz e brutal da sua pátria — a crítica do panfletário — mas sempre com o pensamento numa pátria melhor; será depois o amor expresso e declarado do artista que os anos tornaram sereno e mais compreensivo" (LINS, 1939, p. 282). Por conseguinte, pode-se inserir Álvaro Lins no grupo de críticos queirosianos que não veem a obra de Eça como instrumento de luta política e social. Tanto 
é verdade que o crítico chama a atenção dos leitores do autor português para que eles "não tomassem muito ao pé da letra” (LINS, 1939, p. 282) as palavras dele sobre Portugal.

Assim, Lins considera que, na obra de Eça, havia mais uma revolta frente ao que parecia não poder mudar em seu país do que uma perspectiva socialista e revolucionária de transformação dessa realidade. A respeito disso, o crítico brasileiro salienta que era "preciso que um povo nem fique a vida toda olhando para trás, contemplativo e estático, nem avance tumultuariamente quebrando as suas tradições — eis o sentimento nacional de Eça de Queirós” (LINS, 1939, p. 297).

Ao que tudo indica, Lins concebe um Eça que via na ideia de civilização a solução para os problemas de Portugal, mas não um progresso avassalador e desumano. Ademais, o crítico destaca o fato de que grande parte da crítica via na obra de Eça uma entrega ao estrangeiro, sendo que, para Lins, era exatamente o oposto.

\subsection{O Eça de Álvaro Lins}

Em resumo, o que prevalece na crítica de Lins é a imagem de um Eça criador de uma realidade imaginária. A preocupação do crítico estava mais voltada à obra do que à vida do escritor, o que, para a época, fora uma inovação, já que a abordagem predominante dos críticos na década de 1930 era a biografia. Assim, Lins volta-se à discussão de gênero literário, destacando o romance como "aquele que melhor realizaria a sua [Eça] vocação artística” (LINS, 1939, p. 91).

No levantamento de elementos da obra de Eça, Lins invoca uma perspectiva impressionista, no sentido de interpretar, sugerir e julgar. Desse modo, observa-se que ele transita entre a vida e a obra de Eça mediante uma visão subjetiva. Valendo-se da 
afirmativa de Adélia de Meneses: “A atenção às sensações pessoais ante o texto é um dado constante da crítica de Álvaro Lins” (MENESES, 1979, p. 78).

É possível verificar, no estudo de Lins, um caminho inverso a dos críticos de sua época: em vez de procurar a obra no homem, ele procurou o homem na obra. Dessa forma, o crítico traçou paralelos entre a vida e a obra de Eça no sentido de esta transfigurar artisticamente o real.

Portanto, Lins como o fizera Eça, rompe com o seu tempo e deixa uma crítica, como observa Carlos Reis (2000), que antecipa leituras que são realizadas hoje. Dentro dessa visão que transgride as ideias vigentes de sua época, o brasileiro concebe a obra de Eça como um todo orgânico, em que estariam ligadas às obras iniciais àquelas escritas na fase madura, todas com um único propósito: representar artisticamente a realidade portuguesa (e por que não mundial) do final do século XIX. 


\section{José de Melo Jorge: Eça, criador de tipos}

Eça de Queirós criou algumas figuras imorredouras pelas suas manifestações psicológicas, pelas suas atitudes, pelas suas taras, pelo seu desconhecimento do senso do ridículo, pela sua grandeza ou pequenez, pela sua naturalidade, enfim.

José de Melo Jorge

A crítica literária brasileira, na década de 40, estava vivendo um grande momento e florescia rapidamente. A atividade editorial indicava o aumento do interesse das coleções especializadas em Literatura Brasileira e também a Literatura Portuguesa estava no centro das discussões literárias. Nesse cenário, surgiu o quarto livro sobre Eça de Queirós no Brasil intitulado Os tipos de Eça de Queiroz (1940), de José de Melo Jorge (? -?).

Melo Jorge inaugura uma leitura crítica queirosiana baseada em uma análise tipológica com base biográfica. Pela primeira vez foi abandonada a visão estritamente biográfica do escritor português para dar espaço à observação acerca de um dos principais aspectos dos textos de Eça: a caracterização dos personagens.

Miguel Mello, Viana Moog e Álvaro Lins reconheceram o tipo como um dos principais recursos na obra de Eça, apesar de não terem caminhado por esse viés. Assim, Melo Jorge, dando um tratamento diferente dos seus antecessores, opta por verificar os personagens tipos da produção literária do autor português, afirmando que eles "não são anjos ou brutos, são, apenas homens” (MELO JORGE, 1940, p. 20).

O crítico brasileiro salienta o aspecto cômico da obra de Eça, ao afirmar que fora através do riso que o escritor conseguira "a demolição de um conservantismo errôneo e visível” (MELO JORGE, 1940, p. 20). Logo, os tipos que Eça criara desempenharam a função de crítica da sociedade portuguesa. Melo Jorge se adiantou e foi contundente ao defender que "tais tipos, satíricos e epigramáticos, são nada mais que um derivativo 
freudiano de sua psicologia complicada” (MELO JORGE, 1940, p. 22). Mais uma vez é colocado em questão o fato de a produção literária de Eça estar embasada em uma psicologia complexa, derivada da divulgação de sua infância conturbada, o que justificaria, portanto, personagens tão problemáticos:

Filho espúrio de um amor só mais tarde legalizado, vivendo seus primeiros anos no afastamento de um vilarejo pobre, tratado pela bondade inculta da família de um alfaiate, vingou-se, posteriormente, já escritor, decalcando mordazmente a sociedade que o inibira de gozar as inefáveis doçuras maternais, tão necessárias à primeira infância. (MELO JORGE, 1940, p. 22-23).

Para o crítico, em vista disso, os tipos de Eça teriam um único fim: vingança contra a sociedade portuguesa. Essa visão veio complementar aquela proposta por Álvaro Lins um ano antes, que também creditava, ao escritor, uma faceta vingativa.

\subsection{Os personagens tipos: retratos da vida de Eça}

A partir da situação típica, Melo Jorge inicia seu estudo pela figura mais marcante da obra queirosiana, o "turista intelectual” ${ }^{62}$ Fradique Mendes. O personagem fora criado por Eça com uma função heteronímica, que, por meio de troca de cartas com o próprio Eça ou com amigos do autor (A Correspondência de Fradique Mendes), colocaria suas ideias ao leitor.

Primeiramente, Melo Jorge afirma que Fradique fora criado com base em amigos do escritor e, para sustentar a sua hipótese, o crítico brasileiro se utiliza da própria citação de Eça: "Fradique não existe. É uma criatura feita de pedacitos dos meus amigos. A sua robustez física, por exemplo, tirei-a de Ramalho” (apud MELO JORGE, 1940, p. 25). Essa afirmação de Eça gerara polêmica entre os críticos brasileiros e portugueses, pois reabre a

\footnotetext{
${ }^{62}$ Expressão utilizada por Benjamin Abdala Jr. (2000).
} 
discussão que começou no final da década de 30, com Viana Moog, acerca de um possível caráter autobiográfico na obra em questão.

Em um segundo momento, Melo Jorge afirma que, além de representar as figuras dos amigos, Fradique “é o ideal masculino do fim do século XIX” (MELO JORGE, 1940, p. 25). A respeito desse assunto, o crítico acrescenta: "Nele foi consubstanciada a nobreza, a distinção e a elegância do Conde de Resende, o harmonioso e o elevado da poesia filosófica de Antero, a profundeza de caráter e o aprumo de Ramalho, a sutileza e a ironia de Eça” (MELO JORGE, 1940. p. 25) ${ }^{63}$.

E, em um terceiro momento, o crítico revela que entende Fradique como um alter ego de Eça: "literariamente, autor e personagem estão sempre de acordo" (MELO JORGE, 1940, p. 31). Cunhando Fradique de “pupilo” de Eça, o crítico observa que o autor se projetara no personagem por meio das características que ele não possui, mas que gostaria de ter possuído. Logo, para Melo Jorge, Eça colocara em Fradique tudo que ambicionara: “uma esplêndida solidez sã e viril” (MELO JORGE, 1940, p. 33). Convém observar que o crítico resume a imagem de Fradique como sendo a do Eça diplomata, exilado com as atividades de diplomacia, mas conseguindo retirar disso um fio irreverente e sarcástico.

O segundo personagem tipo analisado é Conde de Abranhos do romance que leva como título o nome do personagem O Conde de Abranhos e, novamente, Melo Jorge recai na vida de Eça para compreender a construção do personagem. O crítico propõe que esse também seria um tipo que representava o próprio escritor e, para comprovar tal suposição, comparou o casal que cuidou de Eça na infância com o pai de Abranhos: "Era filho de um alfaiate de Penafiel, homem modesto e bom, iletrado e sobranceiro, modelado, talvez, a imagem e semelhança daquele outro alfaiate de Vila de Conde, pai de criação do insigne romancista” (MELO JORGE, 1940, p. 35).

\footnotetext{
${ }^{63}$ Em Portugal, quem defendeu essa ideia foi Antonio Cabral em Eça de Queiroz, a Sua Vida e a Sua Obra. Cartas e Documentos inéditos, de 1916.
} 
É especialmente no âmbito da vida universitária que o paralelismo entre Abranhos e Eça se faz de modo mais consistente:

esta caminhada a Coimbra era, em Portugal, como em todos os países de civilização importada pelo último navio, uma necessidade inadiável. A ausência de centros de cultura técnica especializada determina este esforço pela conquista do bacharelado. O título serve, nestas sociedades, para abrir as mais impenetráveis portas. É o bacharel quem ocupa os postos de administração, os Ministérios, a Câmara, as Secretarias, e, em todos os setores, as mais variadas posições, de amanuense a diretor. Daí a caça feroz ao diploma, ao "abrete Sezano", notada em todos os livros do autor, livros que não podiam deixar de ser assim, por serem o retrato, sem disfarces, de uma sociedade monótona, sem variações (MELO JORGE, 1940, p. 36).

O crítico revela um Abranhos oportunista e mesquinho fazendo de tudo para subir na vida. Porém, questiona-se: como seria possível aproximar Eça desse personagem? Do ponto de vista de Melo Jorge, a aproximação está na procura de se autoafirmar na e para a sociedade:

Todas estas belas campanhas jornalísticas eram, para si [Conde de Abranhos], apenas, a espera de uma brecha, de uma oportunidade que o guindasse ao poder. Também o Eça, no Distrito de Évora, que digira e adjetivara, procurava um meio de fazer política junto aos Regenadores. Foi, talvez, a sua não participação no conluio, a determinadora desta sátira que foi a sua vingança (MELO JORGE, 1940, p. 41).

Por conseguinte, Melo Jorge retoma a ideia de vingança, sugerindo que Abranhos foi mais um tipo que surgiu da imaginação de Eça com o objetivo de apontar o decadentismo de Portugal em função daqueles que agem como o personagem.

Ademais, observa-se que Melo Jorge realmente usa de maneira conveniente essa aproximação biográfica entre Eça e Abranhos para, assim, revelar que o Conde fora mais concebido com o intuito de criticar as conveniências sociais atingidas por atos indignos do que por outro motivo. Por isso, o crítico enfatiza o lado satírico de Eça que alertara a sociedade portuguesa sobre o fato de que aquele que desejava "fazer política” era quem 
conseguiria subir na vida e o intelectual e o sonhador sofriam com isso. No entendimento do crítico, por consequência, Abranhos se encaixava no espírito corporativo e burocratizante da burguesia portuguesa, conseguindo empregos e títulos facilmente.

O terceiro personagem tipo analisado por Melo Jorge é Gonçalo Mendes Ramires do romance A Ilustre Casa de Ramires. O crítico vê esse personagem como a representação de Portugal do século XIX, aproximando personagem e país pelo complexo de inferioridade:

Gonçalo que tão bem resumia a terra portuguesa, era guiado na vida por um complexo de inferioridade. De nada lhe adiantava ser esbelto, duma brancura sã de porcelana, e ter um corpo rijo; pouco lhe servia possuir todas as armas e títulos dos antepassados, pois faltava-lhe a alma forte desses ancestrais. Era um poltrão de corpo e alma! (MELO JORGE, 1940, p. 48).

Melo Jorge afirma que o meio de ostentação fizera com que o personagem apresentasse um caráter leviano e incoerente. Pensando dessa forma, será que o crítico considerou a hipótese de Eça, já no final de sua vida, retomar o determinismo social empregado no início da carreira? Nota-se que sim, pois toda a análise sobre Gonçalo partiu do princípio de que o personagem, envolvido em um meio tumultuado (de extremos sociais), foi obrigado a se adaptar ao que se exigia daquele meio social. Por isso, para ser importante, ele precisava ser respeitado pela sociedade e, para conseguir essa colocação, Melo Jorge afirma que "impotente para galgar o pináculo da escala social, descia aos degraus mais baixos” (MELO JORGE, 1940, p. 52). Desse modo, o crítico brasileiro denomina o personagem Gonçalo como um “deslocado social” (MELO JORGE, 1940, p. 52) uma vez que, mesmo lutando para se encaixar, ele não conseguia.

Melo Jorge também analisa Sebastião de O Primo Basílio e Titó de A Ilustre Casa de Ramires em conjunto. Para o crítico, ambos representam o sentimento da amizade, o 
que significa que Eça, ao retratar a camaradagem em personagens como Carlos da Maia e João da Ega, Jacinto e Zé Fernandes, Jorge e Sebastião, Gonçalo e Titó, buscara em Zola a concepção de "que a amizade de um homem é mais sólida que o amor de uma mulher" (apud MELO JORGE, 1940, p. 53). Para isso, o brasileiro retoma a vida do escritor para explicar a presença marcante das amizades nos seus romances, evocando a amizade de Eça com Ramalho, com Antero, entre outros.

A explicação deste modo de ser nos é dada pela própria vida do escritor. Enquanto que desde os bancos acadêmicos teve ao seu redor, como guias, amparos e companheiros, um grupo interessado de rapazes, que as vicissitudes da vida não conseguia separar, não houve, por todo este tempo, nenhuma mulher a lhe fazer pulsar o coração (MELO JORGE, 1940, p. 54).

Seguindo pelo viés do biografismo, Melo Jorge salienta que Eça só colocara o amor entre homem e mulher em uma perspectiva positiva e estável em sua obra após ter se casado em 1886 com D. Emília de Castro Pamplona, momento da vida de Eça destacado anteriormente. Tal fato teria dado uma reviravolta na apresentação da personagem feminina e da instituição do casamento na obra queirosiana.

Retomando o lado mais polêmico de Eça, Melo Jorge agrupa alguns personagens para retratar o convencionalismo da sociedade portuguesa e seus vícios. São as figuras dos conselheiros de Estado e dos ministros: Conselheiro Acácio, de O Primo Basílio, Conselheiro Gama Torres de Conde de Abranhos, doutor Margueride, de A Relíquia, Conde de Gouvarinho, de Os Maias, Conselheiro Souza Neto de Os Maias e José Joaquim Alves Pacheco, de Fradique Mendes. São personagens de diferentes romances que representariam a mesmice de uma sociedade ultrapassada.

Na apresentação desses personagens, Eça teria se utilizado de sua experiência jornalística e diplomática para descrevê-los de maneira o mais real possível, colocando-os em situações que envolvessem os costumes e a cultura portuguesa. 
Melo Jorge, durante sua análise dos tipos ecianos, compreende que Eça, na busca pela descrição do real, aproximara-se do determinismo de Taine mais uma vez para retratar os homens da sociedade lusitana. Como exemplo disso, Melo Jorge escolhe o personagem Teodorico Raposo, de A Relíquia, pois, para o brasileiro “Raposão” era o modelo de como o meio pode influenciar na construção do ser. Assim, o crítico brasileiro ressalta o fato de que o personagem inserido em um meio vicioso e imoral, consequentemente, seria determinado por esse ambiente maléfico; contudo, se o personagem saísse desse ambiente e migrasse para um meio mais saudável, sua conduta sofreria mudança. Concernente a esse assunto, Melo Jorge afirma que “fora de um ambiente de moral decrépita, de sabujismo constante, de servilidade contínua, o Raposão começa a ser um homem como outros” (MELO JORGE, 1940, p. 85).

E, com relação ao tema da influência do ambiente, Melo Jorge aproxima o criador da criatura e defende a seguinte hipótese: a distância dos pais durante a infância e a ida à Coimbra são reveladores da possível teoria do crítico brasileiro sobre o fato de Eça ter realizado uma obra autobiográfica. Não obstante, o crítico externa a diferença moral entre eles, isto é, enquanto o personagem, determinado pelo meio, esforça-se para ser aceito socialmente, Eça estava distante de se adaptar às convenções sociais.

Outro personagem que sofrera com a influência do meio, segundo Melo Jorge, fora Juliana, de O Primo Basílio. Ele a concebe como a representação da criadagem portuguesa ${ }^{64}$. O crítico afirma que ela procurou, durante toda a sua vida, fugir do seu destino de servidão e humilhação; porém, essa fuga da realidade da personagem a levou a revoltar-se e conspirar contra a protagonista Luisa.

\footnotetext{
${ }^{64}$ Essa afirmação de Melo Jorge e de tantos outros críticos não foi totalmente aceita em Portugal, pois foi vista como uma generalização da criadagem lusitana.
} 
Ambicionara, desde cedo, ter algum dinheiro de seu para montar um negócio. Como dona de uma quitanda, seria, naturalmente, diferente a sua vida. O que lhe azedava a existência, trazendo-lhe um desconsolo constante, era a obrigação de trabalho sob ordem dos outros, o dormir em cacifros, levantar-se de madrugada, comer restos, vestir trapos velhos, sofrer os repelões das crianças e as más palavras das senhoras. O ferro de engomar chegava a revolucionar-lhe o estômago (MELO JORGE, 1940, p. 89).

O crítico descreve-a como invejosa, não aceitando a sua vida e o sentimento de inferioridade que a dominava. Ela foi considerada responsável pela trama central de $O$ Primo Basílio e sem ela, conforme Melo Jorge e Machado de Assis, o romance não teria uma trama.

Do outro lado da moeda, Melo Jorge escolhe dois personagens: Trutezinho, de $A$ Ilustre Casa de Ramires e o avô Afonso, de Os Maias, para representarem a integridade, ou seja, “dois espécimes admiráveis de uma raça ideal, dois titãs impressionantes na sua grandeza de caráter, duas almas de heróis contidas em corpos do mais puro bronze [...]”(MELO JORGE, 1940, p. 97).

Dialogando com Viana Moog, Melo Jorge defende a posição de que o avô Afonso era a imagem recíproca do próprio avô paterno de Eça: “Um e outro foram conspiradores, jacobinos; um e outro tiveram sob sua guarda a primeira infância de um neto, que as tolas convenções sociais e o romantismo exacerbado dos progenitores, tornará um semiórfão" (MELO JORGE, 1940, p. 99). São personagens que destoam dos demais; sem vícios e sem perversidades, são fortes e leais. Em outras palavras, de acordo com o crítico brasileiro, ambos destoam no ambiente vicioso da sociedade portuguesa.

No oposto disso, Eça, para o crítico, criara Artur Corvelo, de A Cidade e as Serras, um homem fraco, "assustadiço, enfermiço, e tinha as maneiras de um homenzinho e a graça nervosa de uma menina” (MELO JORGE, 1940, p. 106). Para o crítico, era uma figura dupla, “de um lado julgava-se inteligente, bom poeta, com ideias originais, imagens, 
estilo; e de outro lado, possuía-o a irresolução para atacar de frente os seus problemas particulares” (MELO JORGE, 1940, p. 108), que, na concepção de Melo Jorge, representa a timidez de Eça.

Melo Jorge usando indiretamente a teoria darwinista (talvez com o objetivo de direcionar o leitor que essa ideia partira de Eça), afirma que Artur Corvelo é o retrato do ser que é fraco, portanto, é derrotado. O crítico também se apropria do psicologismo freudiano para apontar que o personagem sofria de inferioridade. Para o brasileiro, essas características revelam outro aspecto do personagem: o superficialismo, e o crítico defende o argumento que Artur Corvelo foi o porta-voz de Eça ao combater "este superficialismodiletântico, tão de gosto dos meridionais” (MELO JORGE, 1940, p. 113). Assim, conforme Melo Jorge, Eça inserira essas figuras “inferiores” com o intuito de afastá-las de Portugal.

Entretanto, não só de figuras masculinas a obra do escritor português fora dominada. Melo Jorge destaca as figuras femininas como elemento determinante na construção de situações típicas na obra de Eça. De acordo com o crítico, a presença feminina foi significativa para apresentar os diferentes contextos sociais e morais, além de representar a realidade e o destino das mulheres na sociedade portuguesa. Melo Jorge, repudiando a afirmação de Camilo Castelo Branco ${ }^{65}$, classificou-as em cinco grupos: as honestas, as adúlteras, as devotas, as ardentes e as fáceis. Dessa forma, ele estabelece um paralelo entre as mulheres que fizeram parte da vida do escritor com as personagens:

Nelas eu encontro uma reminiscência triste da vida do romancista. Em momento algum, ao tratar da criação de um tipo feminino, ele podia olvidar a estranha sucessão de escândalos que, em seus mais chegados parentes, tinha determinado os casamentos. Seus pais, antes de regularizarem a união, tinham vivido juntos por quatro ou cinco anos. Seu avô paterno fora amasiado, durante muito tempo, quase dez anos, com a mulher com que depois se casou.

\footnotetext{
${ }^{65}$ Para Camilo Castelo Branco, Eça criara somente personagens femininas “desonestas”.
} 
Tal encadeamento de paixões descontroladas, só podia determinar, mais tarde, o que determinou: uma propensão para tipos senão imorais, pelo menos amorais.

[...]

A posição social não é para elas um impedimento à satisfação do desejo [...] (MELO JORGE, 1940, p. 128).

Partindo desse argumento, Melo Jorge estreita a relação entre a obra e a vida de Eça realizando uma análise comparativa entre mulheres reais e mulheres fictícias, manifestando-se no sentido de que as personagens representavam a visão de Eça frente às mulheres que foram presentes na sua vida.

Abandonando o elemento feminino, Melo Jorge inicia sua interpretação do personagem Tomás de Alencar, de Os Maias, vendo por meio desse tipo uma crítica ao Romantismo. Na concepção do crítico, o personagem seria a representação do “pensamento antigo, conservador” (MELO JORGE, 1940, p. 153). Melo Jorge aponta que Eça teria se espelhado em alguém para criar Tomás de Alencar ${ }^{66}$, mas não cita nomes. Na verdade, o que se tinha de concreto para o crítico era que Eça encontrara em Tomás uma forma de representar "uma escola literária derrotada, o principal característico do Alencar: vivia do passado, de rememorações e de saudade. Não era um homem, era um espectro doutras eras, que só no cemitério encontrava um amigo para visitar!” (MELO JORGE, 1940, p. 154). Ao que tudo indica, o brasileiro estava relacionando o personagem à estética romântica e a suas características, tais como: o saudosismo do passado, a fuga da realidade e a morbidez.

Retomando as aproximações entre a vida do escritor e a sua arte, Melo Jorge destaca o personagem Jacinto, de A Cidade e as Serras, como a imagem recíproca de Eduardo Prado: “O Jacinto assim feliz e de vida facilitada pelos fados, tinha o gosto, como dizíamos, de bem entender as Ideias Gerais. Era a superior curiosidade de espírito que

\footnotetext{
${ }^{66}$ A polêmica sobre a origem do personagem Tomás de Alencar girou em torno de Bulhão Pato, que acreditava piamente que ele era o caricaturado de Eça.
} 
Eduardo Prado, conforme afiançou o Eça, seu íntimo amigo, possuía em grau desenvolvidíssimo” (MELO JORGE, 1940, p. 157-158). Desse trecho, pode-se retirar novamente a temática da amizade, em que é possível presenciar uma homenagem que Eça fizera ao amigo brasileiro. E, também desse trecho, observa-se a retomada da hipótese de Eça ter feito autobiografia, ecoando Viana Moog novamente. Nesse sentido, nota-se que Melo Jorge escolhe João da Ega, de Os Maias, para ilustrar esse fato afirmando que ele "pode e deve ser tomado como uma dessas auto-biografias romanceadas, onde, abstraindose uns pequenos atavios, necessários à ação, ficará, completo na sua integridade, o modelo vivo” (MELO JORGE, 1940, p. 167). Assim, a principal característica que os uniu, segundo Melo Jorge, foi o idealismo.

Figura que vem na contramão de João da Ega é José Lúcio Castanheiro, de A Ilustre Casa de Ramires que, conforme aponta o crítico, fora construído por Eça para atacar o típico patriota de pensamentos antigos. Para Melo Jorge, o personagem teve como modelo o "rival” de Eça, Pinheiro Chagas: “Quando em artigo para a Gazeta de Notícias do Rio de Janeiro, atacava Pinheiro Chagas, que saíra a campo em defesa das sagradas instituições patrióticas, Eça de Queirós, pensava, sem dúvida, no arcabouço moral de um de seus tipos” (MELO JORGE, 1940, p. 177).

Para Melo Jorge, Eça retornara, em sua obra, incorporado também pela figura de Dâmaso, de Os Maias, que de acordo com o crítico, assemelhava-se ao escritor, principalmente, no uso simples da gramática: “é a ingenuidade gramatical do personagem, perguntando se embriagues era com m ou n. Este traço e paixão por ser lecionado, é do próprio Eça” (MELO JORGE, 1940, p. 189).

Por fim, Melo Jorge encerra seu percurso pelos tipos queirosianos com "os conquistadores”: André Cavaleiro, de A Ilustre Casa de Ramires; Basílio, de O Primo Basílio; e Padre Amaro, de O Crime do Padre Amaro: “No Basílio [...] está o aventurismo; 
no Cavaleiro, o oportunismo aproveitador; no Amaro, finalmente, a força impelidora da hereditariedade: sua mãe era forte e sensual e o pai morrera de apoplexia” (MELO JORGE, 1940, p. 193). De acordo com o crítico, com esses três personagens, Eça criticara “a inexistência de grandes paixões” e “os grandes egoísmos” (MELO JORGE, 1940, p. 195) da sociedade portuguesa.

Em relação ao exposto, é possível dividir a crítica de Melo Jorge em duas partes: a primeira, composta por um olhar mais geral sobre os tipos de Eça que trabalhou duas hipóteses, a dos personagens como retratos da realidade (próximos de pessoas reais) e dos personagens como instrumento de crítica social e moral. E, uma segunda parte, mais específica, faz um percurso mais detalhado dos personagens distribuídos em pequenos grupos: os políticos corruptos representados por Gouvarinho, Sousa Neto, Pacheco, Conde de Abranhos, Acácio, Gama Torres e Margueride; os artistas românticos por Artur Corvelo e Tomás de Alencar; os bobos por Damaso, Eusebiozinho e José Barrolo; o elemento feminino subdividido entre as honestas por Joaninha; as adúlteras por Luisa; as devotas por D. Patrocínio das Neves; as ardentes por D. Augusta, Maria de Assunção e S. Joaneiro; e as fáceis por Madame Colomb, Mary e D. Joana Coutinho; os conquistadores por André Cavaleiro, Basílio e Padre Amaro; os esnobes por Fradique Mendes; os invejosos por Gonçalo Mendes Ramires e Juliana; os homens dignos por Afonso, Sebastião, Titó e Trutezinho; os idealistas por João da Ega; os patriotas por José Lúcio Castanheiro; os canalhas por Teodorico Raposo; e, por último, os curiosos intelectuais por Jacinto.

Observa-se que, na análise tipológica de Melo Jorge, os personagens foram concebidos por intermédio de uma aproximação direta com a vida de Eça: representações do pai, da mãe, dos amigos, dos inimigos e dele próprio. Buscando encontrar paralelos entre a vida e a obra do autor português, o crítico fez da análise intrínseca um estudo 
biográfico quando procurou relacionar a vida de Eça com a dos personagens, isto é, sendo representantes do agir e do pensar do autor.

Nota-se que, para o crítico brasileiro, o escritor se apropriara da doutrina positivista da época, especialmente nos personagens dos primeiros romances que, do ponto de vista de Melo Jorge, teriam sido moldados pelo pensamento determinista de Taine para mostrar como o meio poderia determinar o homem. Embora Melo Jorge tenha se centrado nessa hipótese, ele também destacou fatores morais e psicológicos dos personagens, especialmente, àqueles dos últimos romances para mostrar que Eça objetivara apontar que não somente os fatores econômico e social condicionavam o homem, mas aspectos subjetivos igualmente.

Em uma análise que parecia ser única na época, pelo fato de estudar aspectos intrínsecos dos romances de Eça, Melo Jorge recai a um biografismo exaustivo ao comparar os personagens fictícios com elementos da vida do próprio autor, diminuindo a análise tipológica que propôs. 


\section{Clóvis Ramalhete: Eça, uma presença invisível}

Eça de Queirós foi um desses plasmadores de conceituações imprecisas, desvendador de um mundo anunciado com sutileza nas inconsciências. Mereceu por isso, culto apaixonado, no largo sítio do Ocidente em que se fala essa velha língua, rude e ignorada.

Clóvis Ramalhete

Embora, na década de 1940, o estudo crítico da obra de um escritor tentava se desprender do modelo biográfico, muitas leituras críticas ainda se prendiam a esse aspecto favorecendo aquelas leituras realizadas mais por admiradores incitados por uma paixão ao objeto de estudo do que por estudiosos vinculados à produção jornalística e acadêmica. Os pesquisadores e leitores de Eça, até então, não hesitavam expor sua admiração por sua vida e obra, porque estudar o escritor de O Crime do Padre Amaro era muito mais do que anseio de um pesquisador; era, na verdade, o prazer de um admirador.

Foi assim com Clóvis Ramalhete (1912-1995), que, mesmo dedicando sua vida ao direito, ao jornalismo e ao magistério, publicou uma única obra dedicada às letras: Eça de Queiroz, de 1942. Essa obra foi laureada pela Academia Brasileira de Letras pelo bom trabalho realizado no estudo da vida e da obra de Eça. Ademais desse livro, Clóvis Ramalhete escreveu alguns artigos tanto em jornais brasileiros quanto em jornais portugueses sobre Eça, o que permite verificar o seu gosto pessoal pelo escritor português. Embora existam essas outras leituras críticas de Ramalhete sobre Eça, foi, em sua obra de 1942, que ele exerceu sua melhor e mais profunda leitura queirosiana.

Dando atenção não somente ao homem e ao escritor, Ramalhete resgatou toda uma época. O crítico conseguiu mostrar ao seu leitor a multiplicidade de Eça, construindo uma biografia acompanhada tanto por sua paixão quanto pelo trabalho sério e árduo de uma crítica literária. 


\subsection{O culto de Eça no Brasil}

Valendo-se das palavras de Alfredo Campos Matos, Ramalhete, no início de estudo, elabora uma "excelente introdução para o entendimento do modo muito peculiar e apaixonado com que, no Brasil, Eça é sentido e compreendido” (MATOS, 2000, p. 499). Assim, ele não hesita em começar seu texto com o culto a Eça no Brasil e em Portugal, introduzindo o assunto com o tema geral de "Cultuados e cultuadores" no decorrer dos tempos. O crítico lembra dos grandes escritores que, além de serem cultuados, também cultuavam e isso se dera também com Eça, muito cultuado por seus leitores e cultuador de grandes artistas de sua época. Ramalhete enfatiza o aspecto humano em torno da consagração, da necessidade humana de “ser” ou “de se fazer" consagrado. Em consonância com isso, ele afirma que “a sociedade, num alvoroço de consagração, ama então o gênio artístico com a gratidão da fêmea fecunda. Quer vê-lo em carne e osso. Procura informar-se de sua vida, de suas gravatas, suas mulheres, sua doença” (RAMALHETE, 1960 [1ª ed. 1942], p. 12) ${ }^{67}$.

Para Ramalhete, Eça merecia ser idolatrado por cinco motivos: primeiro, por ter sido ele o responsável por dar forma a conceitos imprecisos; segundo, por desvendar "um mundo anunciado com sutileza nas inconsciências” (RAMALHETE, 1960 [1ª. ed. 1942], p. 14); terceiro, por realizar uma nova estética; quarto, por dar agilidade à linguagem; e, quinto, por deixar seu riso e sua imaginação recobrirem as coisas e os seres. E foi por meio desses aspectos que Eça foi cultuado e diferenciado dos escritores de sua época, principalmente, no abandono das velhas escolas e da velha estrutura da língua portuguesa. Na opinião do crítico, o jeito agressivo e, ao mesmo tempo, sereno do autor permitira a ele a consagração nas letras, o que resultou no seguinte quadro:

\footnotetext{
${ }^{67}$ Não foi encontrado na $3^{\text {a }}$ edição de 1960 de Eça de Queiroz, de Clóvis Ramalhete nenhuma mudança de concepção em relação à publicação da $1^{\mathrm{a}}$ edição de 1942.
} 
Foi então um delírio! Houve a paixão, a idolatria de Eça de Queirós. Todos o fizeram moda, com seus tipos, seu combate farsante e seu requinte. E mesmo aqueles que não o traziam na mente, seguiam sem o saber, as insinuações de sua ironia. Daquelas páginas brotaram lições logos aprendidas. Era a língua renovando-se. O bom gosto nos interiores, nos hábitos civilizados, no apuro das vestes e da conversa, aprendido com seus personagens. O marasmo da política sem imaginação pondo-se em movimento. Todo um forte organismo social, adormecido, sentiu-se espicaçado - e moveu-se (RAMALHETE, 1960 [1 ${ }^{\text {a }}$. ed. 1942], p. 14-15).

Ramalhete afirma também que Eça foi moda, particularmente entre os jovens de vários países e, sobre isso, Antonio Candido (2000) comenta a recepção de Eça na sua época de estudante quando ele e seus amigos brincavam com os nomes dos personagens queirosianos. Outro pensador significativo nas letras brasileiras, na década de 1950, Gilberto Freyre, também ressaltou o culto a Eça pela classe alta, culta e letrada.

Ramalhete ressalva que o culto a Eça foi além das fronteiras de sua ficção, levantando interesse também por sua vida. A “mania”, como denominou o crítico, fez com que os seguidores do escritor português acompanhassem incessantemente a sua vida e sua obra.

Queriam confundir-se nas ideias dele, paladinar-lhe os combates, as frases, as teorias. Interessavam-se por sua pessoa física como por um modelo ideal. Conheciam minúcias lendárias da intimidade dele, na paixão de sua presença invisível. Eça de Queirós existia poderosamente dentro da imaginação de cada um. E com seus livros e com sua vida, excitou desejos e aspirações. Os novos desejavam modelar-se pelo seu fin du siècle (RAMALHETE, 1960 [1ª. ed. 1942], p. 15).

Para o crítico brasileiro, Eça passara a ser cultuado como um deus e sua invisibilidade aguçava a imaginação de todos que o admiravam. Era visto como um viajante e conhecedor do mundo e que soube como ninguém escrever sobre o homem e suas mazelas. No Brasil, acrescenta Ramalhete, a repercussão perpassou várias regiões e, segundo ele (outros antes dele), foi aqui que Eça, em primeiro lugar, conseguira a 
consagração e fora adotado antes de Portugal. Para ilustrar essa hipótese, Ramalhete percorre diferentes localidades brasileiras para comprovar essa afirmação:

No Maranhão, fundaram uma estranha "Padaria Espiritual Eça de Queiroz”, espécie de Cenáculo brasileiro dos Vencidos da Vida de lá, que se propunha: batalhar pelas letras e amar o romancista. Em Cuiabá, na bruteza da mata entre índios e padres catequistas, lia-se atentamente aquele puro filho da civilização [...] Também em S. Paulo e no Rio havia adoradores (RAMALHETE, 1960 [1ª. ed. 1942], p. 18-19).

Ramalhete salienta que tamanha era a admiração dos brasileiros por Eça que, no ano da morte do escritor, 1900, os seus seguidores entraram em estado de choque e ele destaca entre eles o escritor brasileiro Olavo Bilac que, dois anos antes da morte do autor português, havia-o conhecido em Paris. Em vista disso, o crítico enfatiza a forte comoção que levara Bilac a escrever uma bela despedida na Gazeta de Notícias ${ }^{68}$ no dia 19 de agosto do mesmo ano e, além disso, acrescenta Ramalhete, que Bilac, em 1905, invadira o monumento de Eça em Lisboa, deixando cravos amarelos ${ }^{69}$ e um beijo.

Eça ocupou de tal maneira os gostos e a capacidade de amar do público da língua portuguesa, que, quando morreu, foi geral o sentimento da insuficiência dos literatos sobreviventes. Negava-se a todos a capacidade de oferecer uma obra em substituição à do morto querido. A verve, os personagens, a maneira de romancear de Eça de Queirós, naquele momento de ausência definitiva, pareceram uma revelação superior que ninguém nunca mais alcançaria (RAMALHETE, 1960 [1 ${ }^{\mathrm{a}}$. ed. 1942], p. 22).

Ramalhete destaca o sentimento de abandono dos brasileiros e como os leitores de Eça o consideravam insubstituível. Mas, na realidade, o crítico brasileiro salientou o fato de que, com a morte do autor português, foi difícil aceitar que os personagens dele eram apenas nomes e os lugares da obra, só imaginação.

\footnotetext{
${ }^{68}$ Cf. BILAC, Olavo. Poesia e Prosa Completas. Rio de Janeiro: Nova Aguilar, 2000.

${ }^{69}$ Eça nunca deixara de enfeitar a mesa do escritório de sua casa com cravos amarelos.
} 
O crítico brasileiro afirma que, com a morte de Eça e com o início do Modernismo, Portugal precisava de um substituto na prosa, porém não encontrava ninguém à altura e ele salienta que, apesar da presença do lema modernista "morte ao passadismo", encontrou Eça no meio dessa revolução, um lugar de destaque. Embora, no início do século XX, o percurso da literatura (universalismo $\rightarrow$ regionalismo) tenha sido o contrário do percurso realizado pelo autor português (regionalismo $\rightarrow$ universalismo), a obra de Eça estava mais forte, pois, para o brasileiro, a aproximação entre Eça e os modernistas estava na linguagem. Além do mais, o crítico salienta que a comemoração dos cem anos de nascimento do escritor movimentou Portugal e Brasil, revelando que Eça estava na presença invisível mais presente do que nunca.

A verdade é que o público ledor dispensa teorias de correntes estéticas para achar Topsius engraçado ou Pacheco uma boa descoberta. Eça de Queirós continuou das vitrinas para as mãos de todos os tratamentos. Caminhou ao encontro das mais diversas compreensões. E lá seguiu, ainda satisfazendo e fazendo rir, ou pelo trecho picante de $O$ Primo Basílio que fez Oliveira Martins corar, ou pelo impagável Damaso assinando a retratação com João da Ega, ou pela forte beleza da vida de S. Cristóvão (RAMALHETE, 1960 [1ª ed. 1942], p. 26).

Por meio da leitura crítica de Ramalhete, é possível notar que, na década de 1940, Eça retornava com força total e seus regionalismos transgrediram o tempo e o espaço, alcançando o Brasil quatro décadas depois de sua morte. Segundo o crítico, o escritor português voltava a ser alvo de intensa idolatria permanecendo "vivo o amor pelas coisas dele, o desejo escondido de restaurar a sua presença, tê-lo outra vez elegante, magro, poste de nervos, com o monóculo a cair e a repor, cintilando ironias” (RAMALHETE, 1960 [1ª . ed. 1942], p. 27).

Ramalhete situa Eça de forma plural, aberto na e para obra, especialmente quando o aumento de sua crítica e de seus leitores cresceu substancialmente. Ademais, o crítico 
aponta para o fato de que Eça conseguira invadir o espírito humano, mexendo com os gostos e os sentimentos de quem o leu, como é possível verificar no seguinte trecho:

Viana Moog confessou a jornalistas que precisara escrever o seu volume "Eça de Queiroz e o Século XIX" para desentulhar-se; o romancista de Os Maias, com sua obra, sua vida e as impressões variadas e vibrantes de suas páginas, desde que o descobriu, existia fisicamente dentro dele, ocupava espaço e era preciso atirar fora (RAMALHETE, 1960 [1 ${ }^{\mathrm{a}}$. ed. 1942], p. 30).

Assim, Ramalhete destaca essa excessiva paixão e idolatria por Eça e sua obra por parte da crítica e do público com um único propósito: buscar convencer o leitor brasileiro do grande artista que Eça é e da grande obra que ele produzira.

Há, sim, numa secreta significação evocativa, escondendo-se, mal disfarçando-se em todos esses modos do seu culto, a intenção indefinida de mantê-lo vivo, de arrastá-lo da vida mental para o meio físico ambiente, e pô-lo ainda a circular entre as coisas cotidianas. Já falei por aí sobre essa "saudade impossível” de Eça de Queirós, a vontade íntima que, na imaginação do seu cultuador, o conserva vivo, alimenta-o pelo amor às coisas que foram dele, pela recordação de seus hábitos, a admiração de sua arte, a curiosidade sobre tudo o que se refere à pessoa e à vida dele (RAMALHETE, 1960 [1ª. ed. 1942], p. 31).

O crítico brasileiro salienta a amargura daqueles que, infelizmente, não conviveram com Eça em vida, somente com seus livros e suas biografias e lembra-se de uma visita que fez ao poeta Carlos Magno, que, além dele, estavam presentes Guilherme Figueiredo, Raul Pacheco de Medeiros e Homero Sena. Todos à mesa evocavam Eça de Queirós com extrema intensidade, fazendo o crítico afirmar que “Eça de Queirós nos visitou em toda a sugestão de sua presença invisível” (RAMALHATE, 1960 [1ª. ed. 1942], p. 33) e tentaram deixar a saudade do escritor português através de alguém que, um dia, aproximou-se do autor: 
Álvaro Lins, que preparava a sua História Literária de Eça de Queiroz, soube disso [uma pessoa que viu Eça de Queirós] e foi procurar o homem precioso. Tinha pouco a contar: Foi há muitos anos, em Lisboa. No Chiado, num fim de dia, levantou-se na calçada um murmúrio baixo e curioso "Olha o Eça” - “Ali vai o Eça de Queirós”. E olhando, ele viu o vulto lendário, a famosa silhueta magra, recurva, alta, sempre elegante, num ar de cansaço, e que passava observando lentamente as pessoas e as coisas. - Álvaro Lins voltava sempre a exigir do amigo, que lhe contasse sempre mais uma vez como fora. Queria saber mais, beber aquele minuto de Eça vivo (RAMALHETE, 1960 [1 $1^{\text {a }}$ ed. 1942], p. 31-32).

\subsection{0 processo de escrita de Eça}

Ramalhete afirma que o culto a Eça se deu devido ao estilo do autor, mesmo depois de várias décadas da morte dele, pela "maneira” de escrever. "Maneira” essa que o crítico salienta que o escritor fora

corrigindo-se, instituiu a sua "maneira", a segunda, a deliciosa "maneira” de Eça de Queirós, inconfundível e dandí, excitada de ironia, inquieta e satânica, com vestígios de romantismo e probidades de realista, - em que ele pôde alargar e penetrar como Balzac, atingir a beleza de mármore de Flaubert, exercitar-se no tom real e cru com o vigor de Zola, criar vivos com o espelho de Dickens, o humor de Thakeray e a humanidade de Daudet, ter de cada um deles sem ser o segundo de nenhum, - entregar-se tão bem à paisagem como à narrativa, ou às ideias gerais, acumuladas belezas e encantos em tesouro tão desigual de valores e de níveis, que se debruçam sobre suas arcas, extasiados igualmente, o esteta refinado e o plebeu pouco exigente, - e tudo tocado de um gosto quase sempre fino, aqui vulgar e grosso, logo além espiritual em que há espírito sólido de Portugal patinado a escamas de ouro pelo gênio leve de França (RAMALHETE, 1960 [1ª ed. 1942], p. 39-40).

De forma resumida, o brasileiro faz um paralelo entre a linguagem de Eça com a de grandes escritores da época do autor, afirmando também a presença do estrangeiro na obra queirosiana.

Por conseguinte, Ramalhete traça o percurso de Eça na literatura que iniciara sua trajetória do regional ao universal e, depois, o autor teria realizado o caminho inverso, do 
universal ao regional. Para o brasileiro, o escritor português, ao criticar o homem e a sociedade em geral, nunca abandonara Portugal.

Para Ramalhete, a obra de Eça não poderia ser dividida em fases, porque era produto de um processo de “amolecimento” e “evolução” já que Eça fora se aprimorando com o tempo e, diferente de seus antecessores, que afirmavam que os últimos romances de Eça não mereciam atenção, Ramalhete, além de dar atenção, prestigia os últimos livros do escritor português. Para entender melhor esse "processo" de Eça, Ramalhete analisa três papéis do autor: Eça cronista, Eça romancista e Eça correspondente de jornais.

\subsubsection{Eça, cronista}

De acordo com o brasileiro, Eça, como um bom realista, começara um romântico e fora, por meio dessa estética, que ele surgiu nas Letras com crônicas publicadas na Gazeta de Portugal. Aproximando-se da opinião de críticos que o antecederam, Ramalhete destaca a linguagem inovadora de Eça, que já aparecia nas suas primeiras crônicas, e a repercussão negativa disso no público intelectual.

Lançando-se como folhetinista, pelas colunas famosas da Gazeta de Portugal, Eça levantou sobre si uma onda de riso. Escrevia numa linguagem nova, afrancesada, tumultuosa. Seus folhetins hoffmaneanos criavam mundos de fantasia demente, de quimera delirante. Neles vogavam germanismos tomados de empréstimo a Heine, envoltos em véus brancos e fofos de abstração - druidas, Margarida e Fausto, cerveja de Heidelberg, baladas da Turíngia e o abade de Tritheim "vendendo a alma pelo segredo da circulação do sangue”. Foi um coro de risadas! Ele, porém, seguiu indiferente, com uma conviç̧ão imperturbada e invejável (RAMALHETE, 1960 [1ª ed. 1942], p. 46-47).

O crítico brasileiro retrata um Eça ainda romântico, inseguro com a escrita, "cru” no início da carreira literária, mas encontrara resquícios da ironia, um ímpeto que ainda 
estava por surgir. Embora Ramalhete concebesse positivamente os primeiros textos do autor, foi levantado um aspecto negativo que marcara o Eça cronista: o excessivo uso da realidade abandonando, por vezes, o jogo imagético da literatura. Assim, de acordo com o brasileiro, a realidade "a disciplinou, reteve seus voos fantásticos, prendeu-a terra-a-terra na preocupação da 'literatura experimental' então em voga. Mas em certos momentos a tirania da verdade banal da rua sufoca-o” (RAMALHETE, 1960 [1ª . ed. 1942], p. 49).

Segundo Ramalhete, a vontade intensa de Eça pela observação da realidade chocava-se com o homem "meridional", que sentia a necessidade de fantasiar e que desejava publicar mais textos como O Mandarim.

Para o crítico brasileiro, quando Eça se aproximara de Charles Baudelaire, ele passara a descobrir "uma categoria nova de arte, um novo mundo de prazeres, de veneno e corrupção requintada, complexo e refinado, todo armado sobre a volúpia sensual da cor e do som” (RAMALHETE, 1960 [1 ${ }^{\text {a }}$. ed. 1942], p. 52). Ademais, o crítico brasileiro se aprofundou nessa “influência” de Baudelaire na produção literária de Eça e afirma que essa aproximação entre o escritor francês e o português fizera com que Eça abandonasse "a exuberância desleixada dos seus escritos" e passou a usar “ideias chocantes" (RAMALHETE, 1960 [1ª. ed. 1942], p. 52). Para Ramalhete, é a partir desse momento que o escritor português iniciou sua jornada de correções, destacando a correção de $O$ Crime do Padre Amaro depois da crítica de Machado de Assis. Por sua vez, para o crítico brasileiro, quando Eça dera início ao seu processo de revisão dos seus textos, finalmente, passara a se destacar como um grande autor. Tanto é assim que Ramalhete afirma que o que se seguiria era o Eça do Cenáculo e das Conferências (muito relatado por críticos anteriores), chegando n’As Farpas. 


\subsubsection{Eça, romancista}

Para Ramalhete, Eça como romancista só passaria a existir após o retorno do autor da viagem empreendida pelo Oriente, quando teria sido ali que ele entrara em contato com outras realidades e não só a de Portugal. Além disso, Ramalhete afirma também o resultado das ideias radicais de Coimbra e o aprofundamento intelectual do Cenáculo, momentos significativos para a construção do romancista.

Observa-se que Ramalhete resgata na produção romanesca de um Eça positivista e materialista sucumbido em manias e crendices que, apesar da pretensa "religiosidade" em sua vida, deteve-se em criticar não necessariamente o Catolicismo, "mas as degenerações da carolice ignorante e do clero burocratizado” (RAMALHETE, 1960 [1 . ed. 1942], p. 87). Pelo clero, para Ramalhete, Eça nutria desprezo como é possível observar em O Crime do Padre Amaro (Padre Natário e Cônego Dias); em A Relíquia (a ambição clerical); em A Correspondência de Fradique Mendes (Padre Salgueiro); e em A Ilustre Casa de Ramires (Padre Soeiro). Esse desprezo seria abandonado, segundo o crítico brasileiro, em A Cidade e as Serras e, à maneira de Júlio Diniz, Eça invocara a figura clerical com suavidade e com poeticidade.

O crítico brasileiro afirma que ao governo e à “politicagem”, Eça reservara alguns momentos de sua obra, escolhendo a organização política da Inglaterra como modelo a ser seguido. Pretenso republicano, "aos políticos conservadores e tradicionais, Eça sempre reservou o melhor da sua zombaria; mas os republicanos e revolucionários que vivem em seus romances, são envolvidos em um pouco da saudade benevolente com que, num olhar retrospectivo, ele evocava os tempos agitados e rebeldes de Coimbra” (RAMALHETE, 1960 [1ª. ed. 1942], p. 90). 
Mais maduro, na opinião de Ramalhete, Eça, enfim, percebera que a política aconteceria independentemente de regime, se fosse feita de maneira respeitosa e digna. Dialogando com Álvaro Lins, Ramalhete afirma que Eça “abraçou um socialismo vago” (RAMALHETE, 1960 [1ª . ed. 1942], p. 91) que, de acordo com o crítico, foi mais uma visão de caridade e de bondade do que um radicalismo político do autor.

Ramalhete não acompanhou a linha de críticos marxistas que via a obra de Eça como um movimento socialista. Ele deixa bem claro que, embora Eça tenha passado a sua vida inteira se comovendo com as desigualdades sociais, não usara a sua obra como "bode expiatório” para suprir suas angústias. Para o crítico, o escritor realista centrara-se no problema que era unânime em Portugal, o domínio clerical. O domínio do pensamento era o que mais incomodava Eça, conforme Ramalhete. Então, o crítico verifica que Eça não objetivava somente expor as mazelas superficiais da Igreja, mas também apresentar ao povo uma Igreja que poderia ser questionada, já que eles próprios não seguiam os seus preceitos.

\begin{abstract}
A existência política da Igreja Católica, na Península Ibérica, parecia a Eça de Queirós e seus amigos um estorvo asfixiante. Vê-se como era essa preocupação maior de todos eles, no programa das Conferências do Casino: Antero de Quental falou sobre as causas da decadência da Península, apontando a dominação clerical como coincidindo com o declínio do arrojo lusitano; Salomão Saragga anunciou o debate sobre a divindade de Jesus; mas nenhum deles preocupou-se com o problema das classes. Ele seria uma de suas cogitações, mas das menores. (RAMALHETE, 1960 [1 $1^{\text {a }}$ ed. 1942], p. 94).
\end{abstract}

Desse modo, Ramalhete afirma que em vez de socialista e panfletário, Eça fora um observador que, por meio da ficção, criou uma galeria de tipos deformados pela ironia e seria como correspondente que ele se sentiria mais livre para discutir política mais diretamente. 
Ramalhete ressalta que, como um típico romancista, Eça assumira o gênero pelo fato de ser o romance uma produção escrita própria para apresentar a realidade de sua época: “Eça de Queirós foi uma antena sutilíssima às vibrações de sua época. Ajustou-se à trajetória do espírito contemporâneo e deixou-se fecundar por ele. E como a elaboração literária do seu tempo era o romance, - instintivamente foi romancista, como um instrumento cego das forças naturais” (RAMALHETE, 1960 [1ª . ed. 1942], p. 111).

Em vista disso, Ramalhete verifica que Eça fizera um longo percurso até atingir sua genialidade: da aventura literária em O Mistério da Estrada de Sintra, do realismo estético em O Crime do Padre Amaro e O Primo Basílio, do fantástico em A Relíquia, das "cenas da vida portuguesa” em Os Maias, da decadência dos portugueses em A Ilustre Casa de Ramires e da vida bucólica de A Cidade e as Serras, formara-se o grande romancista português. Por tudo isso, para o crítico, é errado perguntar qual seria o melhor livro de Eça, posto que, para o brasileiro, isso é o resultado da falta de compreensão da obra como um todo, já que existe uma uniformidade, não podendo nem separar sua produção literária em fases como defenderiam muitos críticos queirosianos. Segundo Ramalhete, Eça é completo em seu todo e não em fragmentações e divisões esporádicas.

\subsubsection{Eça, correspondente de jornais}

Além de extraordinário romancista, o crítico ressalta também a função de correspondente de jornais $^{70}$ de forma positiva. Para Ramalhete, fora nessa função que o autor passara a observar e a descrever a realidade à sua volta: "desde o assentamento ligeiro de uma notícia mundana ou criminal, à narrativa dos acontecimentos políticos

\footnotetext{
${ }^{70}$ Cf. MINÉ, Elza. Eça de Queirós, jornalista. Lisboa: Livros Horizonte, 1986.
} 
internacionais, estava amadurecida em Eça de Queirós, na sua maneira mais digna e elevada” (RAMALHETE, 1960 [1ª ed. 1942], p. 185).

Conforme Ramalhete, fora no jornal que Eça conseguira estruturar o espírito do século XIX e revelar os problemas que se sucederiam. Sempre deixando o seu ponto de vista, ia apresentando aos seus leitores um fato histórico, político e social importante de sua época, o fim do liberalismo. Também usando de ironia, fora criando páginas para a História, que, segundo o crítico, "traçava então com mão irônica, a teoria do envelhecimento dos grandes episódios históricos” (RAMALHETE, 1960 [1ª . ed. 1942], p. 202).

Mesmo Ramalhete caminhando pelo biografismo, ele faz o estudo da obra de Eça com menos interferência da vida do autor em comparação com Miguel Mello e Viana Moog. Ele traz à tona uma discussão do ponto de vista da crítica sociológica, quando concebe a produção de Eça como importante instrumento social e histórico.

Também diferente de muitos estudiosos queirosianos, Ramalhete não concebe a obra de Eça dividida em fases, haja vista que o crítico afirma que a produção do escritor português era unificada, sendo um texto o complemento do outro. Porém, verifica-se um deslize de concepção, pois o brasileiro desenvolve um argumento paralelo de que a obra queirosiana poderia ser visualizada entre uma produção do Eça jovem (revolucionário) e outra do Eça maduro (ponderado).

Assim, tanto Ramalhete quanto seus contemporâneos produziram uma crítica queirosiana que deu origem a muitas outras leituras sobre Eça, mas, apesar disso, ainda se confundia em determinados momentos na análise, deixando lacunas para serem 
preenchidas por outros queirosianos. E no preenchimento desses espaços, surgiram outros estudos sobre o autor, nos quais é possível encontrar em alguns a herança da crítica seminal e nos demais a total ruptura com esse primeiro movimento exponencial da crítica sobre Eça no Brasil. 


\section{CAPÍTULO II}

ECOS DA CRÍTICA SEMINAL

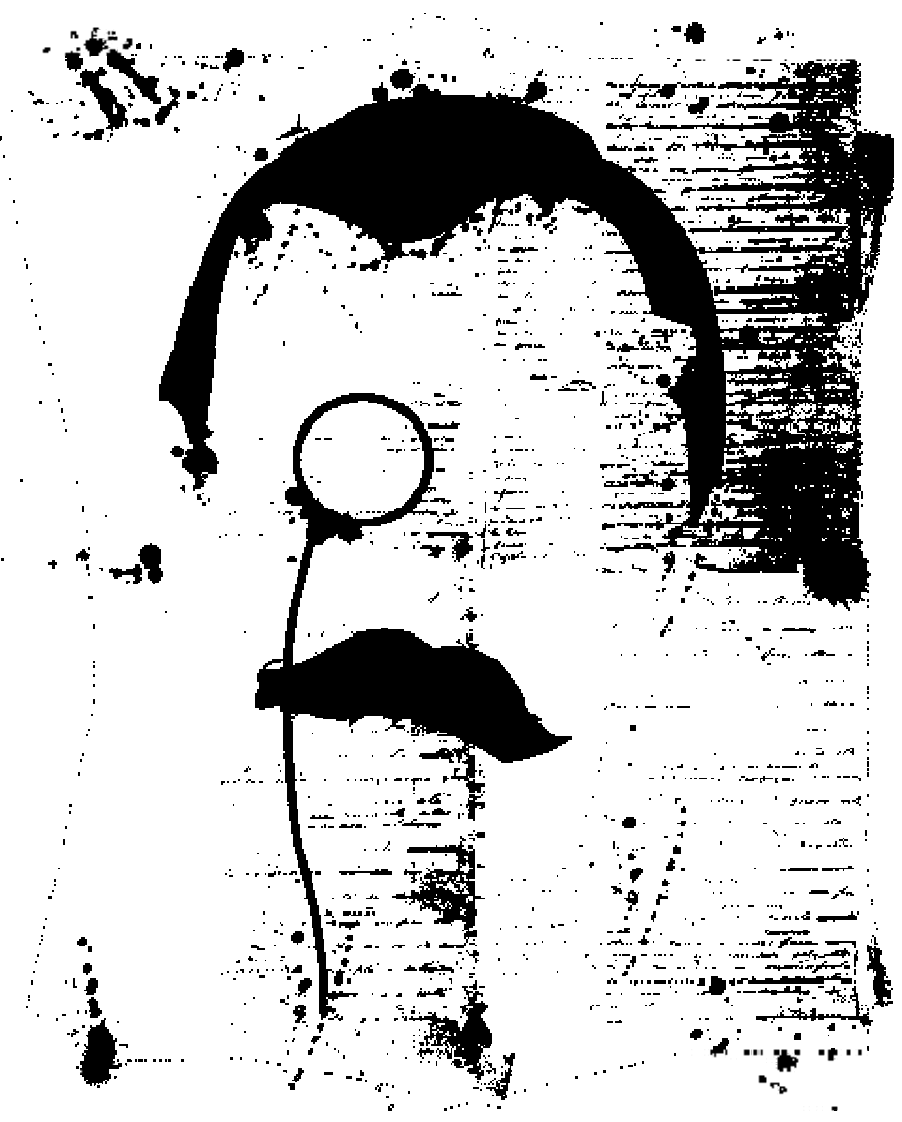

Só a Arte garante imortalidade.

Eça de Queirós 


\section{A herança da crítica seminal sobre Eça de Queirós no Brasil}

Apesar do desenvolvimento da crítica literária na década de 1940 no Brasil, com o surgimento de diversas perspectivas críticas, muitos estudos queirosianos, a partir desse momento, reproduziram as ideias da crítica seminal embasada no biografismo, no psicologismo e na perspectiva sócio-histórica.

Diversas publicações sobre Eça entre as efemérides (1945-2000) recorreram à visão reducionista que dominou, em grande parte, as leituras ecianas até 1945 . Sobre isso, o renomado pesquisador, Alfredo Campos Matos (2002), afirma que a recepção crítica desse período “apresenta matéria profundamente discrepante e contraditória” (MATOS, 2002, p. 214), especialmente sobre as últimas obras do escritor português.

A imagem do artista talentoso, mas sem ideias, toma força e continua no centro das discussões de alguns estudos, que focalizam o estilo, a ironia, a maestria literária, porém não se preocupam com pensamentos políticos e filosóficos de Eça e muito menos com o trato dele em relação a diferentes gêneros textuais. Além de insistirem em analisar a obra a partir da vida do autor, o que, para esta tese, é vista como uma releitura da crítica seminal.

\section{A análise sócio-histórica sobre Eça}

Na retomada da perspectiva sócio-histórica empreendida pela crítica seminal, têmse alguns ensaios do Livro do Centenário: "Lusitanidade e universalidade em Eça de Queiroz”, de Gilberto Freyre; “Eça de Queiroz e o espírito de rebeldia”, de Moisés Vellinho; “Posição política de Eça de Queiroz”, de Álvaro Lins; “Eça de Queiroz e as influências provincianas”, de José Lins do Rêgo; “Eça de Queiroz cronista”, de Astrogildo 
Pereira; “Eça de Queiroz contista”, de Lauro Escorel; “Conceito e técnica do romance em Eça de Queiroz”, de Olívio Montenegro; e “Os temas religiosos de Eça de Queiroz”, de Luiz Delgado. Ademais, surgiram alguns volumes que completam essa abordagem como a coletânea Eça de Queiroz. Documentário de uma comemoração (1947), organizado pela Diretoria de Documentação e Cultura de Recife (DDC), Ideias de Eça de Queiroz (1946), de Francisco Werneck e O lusitanismo de Eça de Queiroz (1947), de Cassiano Nunes. Porém, antes de debruçar-se sobre esses estudos, é importante contextualizar o Livro do Centenário, que marcou os estudos queirosianos no Brasil.

O organizador português Câmara Reis, ao comentar sobre a elaboração do volume, na "Nota Final” do livro, relata a árdua tarefa de reunir os trabalhos de diferentes e conceituados estudiosos. Ele, em uma espécie de desabafo, agradece todos que ajudaram diretamente ou indiretamente na realização do volume; entretanto, é possível observar que salta de seu texto o ressentimento atribuído ao silêncio dos familiares de Eça perante a publicação do Centenário. Câmara Reis envia uma carta ao filho do autor, Antônio Eça de Queirós, convidando-o a participar do volume com uma contribuição própria ou com inéditos do pai que possivelmente se encontravam em seu poder, mas, para a tristeza dos organizadores, a resposta nunca veio e o estudioso português desabafa assim: "Se esse silêncio se explica pelo receio de que o volume não viesse a ficar à altura do grande escritor, os leitores de hoje e futuros poderão julgar a justiça de tais apreensões” (REIS, 1945, p. 72).

Também desabafando, Lúcia Miguel-Pereira abre o volume com o "Prefácio" revelando também as dificuldades encontradas na elaboração do Centenário e faz uma crítica àqueles que tinham prometido participação certa no livro e, na última hora, não entregaram à organizadora nenhum estudo sobre Eça. Contudo, ela salienta que os quinze 
participantes brasileiros são de renome e que contribuíram, cada um de sua forma, para construção do livro que homenageia o escritor português.

Homens de gerações e de tendências diversas trazem o seu depoimento sobre Eça de Queirós, com aquela sinceridade que é a melhor homenagem a um artista de seu porte, a quem não diminuem as divergências. Os aspectos estudados foram-no conscienciosamente, lucidamente, e nos revelam como, mais de quarenta anos depois de sua morte, é ainda viva no Brasil a presença do romancista português (MIGUEL-PEREIRA, 1945, p. 9-10).

A organizadora lembra que Eça fora amplamente divulgado e aceito no Brasil, porque, além de suas publicações literárias, destacara-se também no jornalismo. Por isso, verifica-se que Miguel-Pereira considera a participação de Eça nos jornais importante elemento difusor do estilo queirosiano no país.

Lúcia Miguel-Pereira além de destacar a idolatria brasileira pelo autor português, também ressalta a importância da obra de Eça em outros países, afirmando que os textos queirosianos tinham sido traduzidos para outros idiomas, daí a presença de ensaios em espanhol e em francês no Centenário. Sob esse prisma, nota-se que o volume é dividido em três partes: a primeira parte contando com a colaboração de estudiosos brasileiros; a segunda parte, com a colaboração de estudiosos hispano-americanos e franceses; e a terceira e última parte, com a colaboração de estudiosos portugueses.

Dos quinze ensaios brasileiros, oito deles se debruçam sobre a obra de Eça pelo viés da perspectiva sócio-histórica na retomada da discussão sobre o valor político-social da produção escrita do autor português, centrado, de modo geral, no debate sobre o que eles consideram "forma" e "fundo" ${ }^{71}$.

\footnotetext{
${ }^{71}$ Retomando a discussão da crítica seminal, que polemizou sobre quais dos dois aspectos, "forma” (estilo) ou "fundo" (conteúdo), fora a grande marca da obra de Eça.
} 
Gilberto Freyre (1900-1987) abre o Centenário defendendo a ideia de que a obra de Eça representava a aristocracia e a burguesia e se distanciava do povo, trajetória oposta dos contemporâneos espanhóis do autor português, Miguel de Unamuno e Angel Ganivet. Segundo Freyre, estes produziram os "livros mais significativos que já se escreveram sobre as relações do que é nacional com o universal” (FREYRE, 1945, p. 28). Assim, de acordo com essa afirmação, Freyre aponta para o aspecto paradoxal da obra do escritor português, mais exatamente um conflito entre "o homem da província e o homem do mundo; entre o português e os outros europeus; entre o primitivo e o civilizado” (FREYRE, 1945, p. 24).

Nota-se que, a partir dessas dicotomias, Gilberto Freyre recupera a mudança de comportamento de Eça frente a Portugal ao retomar a diferença entre os primeiros e os últimos romances queirosianos. Compreende-se que o estudioso brasileiro aceita o caráter divisório da obra queirosiana difundido pela crítica seminal e, consequentemente, a mudança na escrita do autor dos primeiros livros para os últimos. Porém, diferente de seus contemporâneos, com exceção de Álvaro Lins, recebe positivamente o romance A Ilustre Casa de Ramires, amplamente criticado na ocasião, especialmente pelos compatriotas do autor. Logo, ele defende também A Cidade e as Serras no sentido de que ambas trazem à tona a discussão da oposição entre a lusitanidade e a universalidade, afirmando que Eça “opõe à dispersão de indivíduos pelo mundo, a que tende tanto a gente portuguesa, aquela lusitanidade quase seita religiosa de homens presos à província como a uma terra santa” (FREYRE, 1945, p. 25).

Gilberto Freyre observa que possivelmente Eça teria simulado ao público que sua mudança de atitude frente à literatura, nos últimos livros, devia-se a forças sentimentais e comportamentais. Contudo, Freyre descarta essa imagem criada pelo escritor e entende que a mudança ocorrera devido a uma nova “filosofia política” que aparece 
em alguns dos romances e em muitas crônicas e artigos de jornal de Eça de Queirós. Não é uma filosofia que se baseie em sério ou severo esforço de análise ou compreensão sociológica do caso português ou do fenômeno do cosmopolitismo no século XIX. Ela se baseia antes em intuições, em observações e reações pessoais aos acontecimentos da época, em generalizações às vezes de bom efeito jornalístico e mesmo literário, mas de pouco ou nenhum fundamento histórico e sociológico (FREYRE, 1946, p. 25).

Essa filosofia política faria com que Eça lesse a trajetória de Portugal como a de "uma nação de simples imitadores, adotando instituições e estilos de vida de outros povos com uma passividade que chegaria a extremos ridículos” (FREYRE, 1945, p. 26).

A tradição portuguesa criticada por Eça, como lembra Freyre, advinda dos preceitos religiosos instituídos pelos jesuítas e pela Inquisição, fora responsável pelo fechamento de Portugal às coisas externas. O brasileiro compreende que o escritor português desejava mostrar, em sua produção escrita, a necessidade de um desapego a tais tradições e o fizera se utilizando do francesismo: "aspecto principal do cosmopolitismo em que se extremaram tantos portugueses do século XIX, atraiçoando a boa e saudável tradição da gente lusa [...]” (FREYRE, 1945, p. 27). Assim, nota-se que Freyre acredita que Eça vivera um conflito entre "o nativismo e o universalismo; o casticismo e o internacionalismo; a lusitanidade e a universalidade” (FREYRE, 1945, p. 27), que fora, porém, amenizado no fim de sua existência, quase alcançando uma conciliação entre tais tendências.

Na análise de Gilberto Freyre, é possível observar nas entrelinhas que, ao considerar a obra de Eça voltada para o local, ele afirma que a produção queirosiana fora construída da e para a aristocracia e da e para a burguesia, opinião que receberia muitas críticas de outros queirosianos que defenderam a amplidão da obra de Eça para todos.

Outro estudo que trata da lusitanidade na obra de Eça é o breve ensaio ${ }^{72}$ de Cassiano Nunes, que está dividido em três partes denominadas, respectivamente:

\footnotetext{
${ }^{72}$ O texto de Cassiano Nunes foi premiado pela Associação Brasileira de Escritores (seção de São Paulo) com o prêmio "Antonio Pousada".
} 
“Preâmbulo Necessário”, “Portugal na obra de Eça de Queiroz” e “O Patriotismo de Eça de Queiroz”, nas quais Cassiano Nunes revela um Eça voltado e preocupado em retratar a terra e o homem lusitano.

À luz disso, na "Primeira Parte" de seu ensaio, o estudioso brasileiro adverte a subversão na qual a imagem de Eça fora sendo construída com o tempo. Ele salienta a famosa figura do escritor português usando seu monóculo e suas vestimentas sempre alinhadas e elegantes, vendo nessa figura "a sua sinceridade, a sua ternura pela sua terra, o seu sentimento do mundo e a sua dignidade humana e literária” (NUNES, 1947, p. 10).

Referendando o trabalho de Clóvis Ramalhete, Cassiano Nunes resgata o culto à Eça em Portugal e no Brasil a fim de retratar os dois lados da moeda: a recepção favorável e desfavorável sobre o autor e sua obra. Ele monta um quadro ilustrativo dessa disputa entre os dois lados citando nomes conhecidos das letras e seus posicionamentos frente à obra queirosiana. Inicia pelos que são à favor e comenta a idolatria da juventude portuguesa por Eça, invejando-lhe “as viagens, os paradoxos, os conhecimentos aristocráticos, e seguia os seus padrões de cultura e os seus modelos de elegância” (NUNES, 1947, p. 11). No Brasil, Cassiano Nunes ressalta a “mania” (termo anteriormente divulgado por Ramalhete) de Eça, para retratar a grande admiração dos brasileiros pela obra do escritor português. Nunes inicia o seu percurso referindo-se à Martins Fontes, que, na opinião do ensaísta, fora o "grande conhecedor de Eça com toda a sua geração literária, e autor de excelente conferência sobre esse escritor - enlouqueceu tentando decorar Os Maias” (NUNES, 1947, p. 11). É notável como Cassiano Nunes lembra adequadamente a recepção carinhosa por parte de gerações inteiras de brasileiros que se aproximaram intelectual e sentimentalmente da obra de Eça. Acrescentando a isso, o crítico comenta um fato inusitado de um brasileiro de Mato Grosso, assinando como "um fanático admirador”, que teria enviado ao autor português uma carta respeitosa, alertando-o sobre um erro em $A$ 
Relíquia. Infelizmente, Cassiano Nunes não informa sobre uma possível resposta de Eça ao brasileiro do centro-oeste do país. Ele acrescenta à lista de admiradores nomes reconhecidos como Marques Rabelo, José Lins do Rêgo, Gilberto Freyre, Álvaro Lins, Viana Moog, Miguel Melo, José de Araújo Jorge e tantos outros que Cassiano Nunes diz que gostaria de citar, mas devido à brevidade de seu estudo - que não perde em nada a outros mais longos e, por tantas vezes, menos originais e eficazes - não se prolonga nessa listagem.

Abandonando os admiradores e centrando-se nos detratores, Cassiano Nunes nota que em Portugal, a lista dos que criticaram Eça é mais extensa do que no Brasil. A justificativa de Cassiano Nunes para esse fato é que, para os portugueses, Eça fora extremamente injusto, retratando a sociedade lusitana como provinciana e viciosa, o que resultara em um mal-estar generalizado. Em virtude disso, Cassiano Nunes afirma: “Acusava-se Eça de estrangeirado, de antiportuguês, de difamador de sua terra e de sua gente. O brio lusitano sentiu-se tocado com os insultos do 'filho desnaturado' e 'traidor'” (NUNES, 1947, p. 15).

Com um tom irônico, bem aos moldes de Eça, Nunes afirma que essa “reação” ao escritor compatriota ocorrera devido ao movimento de espelhamento que aquele setor da sociedade portuguesa sofrera ao se ver "realisticamente fotografada, precisava defender-se das graves, vivas e indestrutíveis acusações” (NUNES, 1947, p. 15). O que resulta desse movimento, conforme Nunes, é que os grupos criticados por Eça precisavam reagir e, para isso, deviam inverter os papéis “difamando Eça, acusando o acusador” (NUNES, 1947, p. 15). Essa reação fora tão intensa por parte dos portugueses que, para mostrar esse fato, Nunes descreve, com tom de revolta, a alegria apresentada por Fialho de Almeida em relação à morte de Eça. O crítico brasileiro, considerando-o um ato odioso, resume esse momento da seguinte forma: 
[Fialho de Almeida] Vestiu-se afrontosamente de branco no dia do sepultamento de Eça, e muito feliz com a morte daquele homem glorioso e reto, que sempre o admirara e respeitara, foi dizer gracinhas na Avenida. Atitude indigna até para um badameco e muito mais ainda para um literato já famoso na época (NUNES, 1947, p. 13).

Verifica-se no trecho que, em relação aos portugueses que se colocaram contra a produção escrita de Eça, Cassiano Nunes toma as dores do autor realista e defende Eça das acusações sofridas. Para ele e tantos outros, Pinheiro Chagas e Bulhão Pato fazem parte do grupo de difamadores e eram "patrioteiros” que não perdiam a chance de atacar Eça. Para ilustrar essa revolta, Nunes os qualifica com adjetivos esdrúxulos: "ridículo”, “carcomido”, “classicomaníacos”, “despeitados”, “carunchosos” que escreviam “folhetins de gelatina” e “alexandrinos torpes e desengonçados” (NUNES, 1947, p. 14-15).

No Brasil, Cassiano Nunes também nota que grande era a quantidade de detratores de Eça. Todavia, destaca um único nome célebre, Machado de Assis, como era esperado, uma vez que a crítica do escritor brasileiro fora e ainda é destaque na fortuna crítica sobre o autor português.

Nunes concorda com a ideia de seus antecessores de que o Brasil fizera uma recepção mais amigável ao escritor, gerando a ira dos portugueses, que viam nesse notável aceitação, por parte dos brasileiros, o prazer da ex-colônia ao ver seu antigo colonizador ridicularizado pelo escritor. Mas discorda dessa teoria levantada pelos opositores portugueses de Eça, apresentando outra explicação sobre essa intensa idolatria no Brasil:

No Brasil, sofríamos, no fim do século XIX, este "complexo de inferioridade": a inexistência de um grande escritor que conseguisse entusiasmar o público e, de igual modo, resistir a um confronto com os maiores escritores da época, de outras literaturas. Qual dos nossos escritores podia suportar um cotejo com os maravilhosos estilistas, argutos psicólogos e finos artistas que, na ocasião, dominavam, como Flaubert, Zola, Maupassant e Daudet, e ao mesmo tempo ser popular? Nenhum, sem dúvida, pois o extraordinário Machado de Assis, com o 
seu amargo desencanto e a sua sutileza requintada, só muito mais tarde seria compreendido e Alencar servia apenas para uso interno. Apareceu, então, Eça de Queirós, alma ensolarada, meridional, crítico de costumes, criador de tipos, trazendo nas mãos jovens o facho das ideias Novas e usando o idioma com um senso estético até àquela época ignorado (NUNES, 1947, p. 18-19).

Nesse trecho, nota-se que Cassiano Nunes concebe a aproximação de Eça com o Brasil mais pelo uso da língua portuguesa do que por outras virtudes do autor. Tanto é que ele retoma o mote freiriano da imagem do autor como patrimônio comum entre portugueses e brasileiros. Observa ainda que a sociedade e as pessoas criticadas por Eça seriam facilmente encontradas no Brasil. Desse modo, o estudioso brasileiro chega à seguinte conclusão: “os brasileiros não podiam rir dos portugueses ao observarem os personagens de Eça de Queirós, pois esses personagens existiam no Brasil. E talvez até em número bem maior” (NUNES, 1947, p. 19). Cassino Nunes ficava indignado frente à afirmação de que Eça seria visto por aqui como instrumento de sátira a Portugal e, por isso, encerra esse momento do seu estudo afirmando que os brasileiros eram amigos dos portugueses e pensar o contrário seria "uma ofensa contra a inteligência e o caráter do público brasileiro” (NUNES, 1947, p. 23).

Na "Segunda Parte” do ensaio, Cassiano Nunes inicia seu trajeto desfazendo a ideia de que, na obra queirosiana, não havia a preocupação em enaltecer Portugal, dando margem para que considerassem a obra de Eça defensora do estrangeirismo. Nunes afirma que Eça fora “o primeiro prosador português que teve a concepção de um estilo com verdadeiro senso estético” (NUNES, 1947, p. 26) e que, diferente do que imaginavam, soube como ninguém usar o material humano português em sua obra.

Para mostrar a lusitanidade na produção artística de Eça, Nunes destaca inicialmente a própria figura do escritor, que representava o que o português tinha de virtude e defeito. Nunes lembra que o autor reconhecera usar o francesismo em sua obra, 
pois Portugal inteiro sofria influência francesa. Por que ele não? Essa postura faria de Eça um verdadeiro português.

Dialogando com Álvaro Lins e Gilberto Freyre, Cassiano Nunes defende um posicionamento nacionalista da obra queirosiana, visto que ele próprio era a representação ideal do português: “o seu sentimentalismo, o seu romantismo devaneador unido ao senso prático, ao terra-a-terra, à observação realista, são qualidades bem portuguesas [...]” (NUNES, 1947, p. 29). Ademais, nota-se que o ensaísta brasileiro afirma que, por ser um típico português, ou seja, “sonhador, idealista” (NUNES, 1947, p. 30), parecia que o artista Eça transitava entre o romântico e o realista. Essa questão, muitas vezes levantada tanto em Portugal quanto no Brasil, é fácil e habilmente respondida por Cassiano Nunes: “Eça não foi totalmente nem uma coisa nem outra, porque retirou de ambas as escolas o aproveitável, sem se escravizar a nenhuma. Eça de Queirós foi um temperamento romântico com um programa realista” (NUNES, 1947, p. 31).

Nunes por vezes é categórico e, lendo com minúcia, a presença dos espaços geográficos estrangeiros na obra queirosiana relata que

as outras terras aparecem acidentalmente em viagens de personagens portuguesas, e sempre diminuídas se as compararmos com Portugal. Eça de Queirós só mostrou Paris, a ultracivilizada Paris - para elogiar a aldeola de Tormes! A China surge mui bela com as suas personagens mas muito perigosa com epidemias e bandoleiros... Jerusalém surge em A Relíquia muito suja, cheia de mendigos e fedendo. Em sua correspondência, contou-nos que achou Nova York "uma cidade cheia de ladrões" e os Estados Unidos com muito progresso mas sem civilização. Para ele, Havana não passava de "um charcal de suor”, "um paliteiro de palmeiras". Da Inglaterra e do espírito inglês sempre disse coisas tremendas e, no fim da sua vida, o caso Dreyfus e outros escândalos tinham-no desencantado da França, que já não lhe parecia a nobre nação defensora dos oprimidos, como tanto pensara na sua mocidade. Chegamos portanto à conclusão de que Eça de Queirós não diminuía Portugal...elogiando o estrangeiro (NUNES, 1947, p. 31-32). 
Ao defender o lado nacionalista patriótico de Eça, faz coro com Álvaro Lins. O que o ensaísta brasileiro propõe é (re)criar ou desvendar o verdadeiro sentimento de Eça perante Portugal, que pode partir de um olhar crítico sobre o clero português, a educação superficial, a hipocrisia da alta sociedade lisboeta, a infância jornalística e literária e os políticos corruptos para um olhar ameno e glorificador da gente simples e do campo. Em um desabafo, Cassiano Nunes adverte:

Como pôde ser assim tão estrangeirado o escritor Eça de Queirós, se todos os seus livros foram baseados, documentados e inspirados em Portugal, sentidos lusitanamente, e escritos em língua portuguesa para o público português.... (NUNES, 1947, p. 33-34).

Nunes também levanta outro elemento que condiz o seu ponto de vista: Eça não entrara na psicologia dos personagens estrangeiros por não conseguir compreendê-los, isto é, Nunes afirma que o fascinante para Eça era desnudar o pensamento dos portugueses. Em vista disso, nota-se que o ensaísta brasileiro não dá continuidade àquela visão dos seus antecessores que defenderam o argumento de que Eça só teria enaltecido sua pátria em seus últimos romances (Segunda Fase), porque Nunes defende que toda a obra queirosiana está repleta de ternura por Portugal e acrescenta: “Eça foi bem mais um enaltecedor do que um difamador...” (NUNES, 1947, p. 39). Portanto, compreende-se o sentimento de repúdio que Nunes carrega por estudiosos queirosianos que insistiram na afirmação de que, por exemplo, A Cidade e as Serras era um livro de "arrependimento". Além disso, desmerecendo esses últimos romances, Nunes dialogando com Álvaro Lins e Clóvis Ramalhete, alega que A Cidade "poderia ter sido escrito por um francês, inglês ou espanhol, que o romance não teria perdido nada do seu sentido” (NUNES, 1947, p. 41-42). O ensaísta, desse modo, considera, então, O Crime do Padre Amaro mais português do que A Cidade e as Serras, o que revela um posicionamento avesso ao da grande maioria dos estudiosos de Eça. 
Na “Terceira Parte” de seu ensaio, Cassiano Nunes traz um breve panorama histórico de Portugal da segunda metade do século XIX e sua decadência para mostrar os motivos que levaram a mocidade daquele momento a reclamar uma revolução cultural nacional.

Talvez no intuito de não aceitar a divisão em fases da obra de Eça e sim justificar a mudança de rumo dos primeiros romances para os últimos, Cassiano Nunes apresenta trechos escritos por Eça e publicados em “A Catástrofe” (póstuma) retratando a indignação do escritor em ver Portugal sucumbir frente à Inglaterra após o ultimato inglês. Como aponta Nunes, Eça, vivendo em “ardor patriótico”, escrevera a Ilustre Casa de Ramires, onde “contrapôs à decadência portuguesa da sua época o esplendor do tempo antigo, em que Portugal era mais forte e feliz por viver mais junto da terra, mais ligado às suas raízes” (NUNES, 1947, p. 58).

E, nesse espírito patriótico em torno da figura de Eça, Cassiano Nunes encerra seu ensaio jogando para o futuro as expectativas levantadas por Eça com relação ao progresso português.

A partir desse quadro, verifica-se que, por meio de uma perspectiva sociológica, Cassiano Nunes retrata como os conflitos de uma sociedade aparecem em uma obra literária, isto é, como o posicionamento de Eça como artista e, principalmente, como português, aparece em sua produção escrita.

Moisés Vellinho (1902-1980), em seu ensaio, em parte corrobora a opinião de Gilberto Freyre e de Cassiano Nunes no que tange o caráter político da obra de Eça. Percebe-se que Vellinho é mais um queirosiano que valoriza a “forma” e não o "fundo” na obra de Eça, como se pode observar no trecho a seguir: 
E como seu pensamento partidário jamais poderia absorvê-lo ao ponto de prevalecer sobre os reclamos de seu poderoso instinto de artista, havia de ser na forma e não na substância que a inquietação revolucionária trazida de Coimbra finalmente se fixaria, revestindo uma expressão de vitalidade com a qual não é possível emparelhar o interesse político de sua obra (VELLINHO, 1945, p. 40).

Porém, como sendo homem de seu tempo

tomou posição não só contra as forças da inércia, que se opunham, pela má-fé conservadora, ao surto das novas ideias, mas ainda contra as formas do reacionarismo, representadas passivamente por todos os processos de tirania política ou religiosa. Nada lhe repugnava mais que os atentados à liberdade e à livre determinação dos indivíduos e dos povos. Ele foi, sem dúvida, incansável, através de seus livros, de suas maravilhosas crônicas, de sua correspondência, nas investidas contra os desajustamentos e atropelos da política, contra o convencionalismo refratário ao progresso, contra o marasmo das instituições. A beatice, o tradicionalismo paralítico, os vícios da classe média, as fraquezas e cobardias de uma fidalguia que conspurcava seus antigos foros assimilando os grossos apetites da burguesia, tudo isso teve nele um crítico impenitente e afoito (VELLINHO, 1945, p. 42).

Moisés Vellinho, mesmo defendendo a participação social e política de Eça em seu tempo, não acredita em uma postura revolucionária do autor, mantendo a opinião da crítica seminal:

A função militante da arte como expressão dos movimentos sociais, conforme a concebera o escritor na conferência de 1871, cederia à preferência de outros fatores menos interessantes do ponto de vista político-revolucionário. Ao programa então defendido com tanta ênfase Eça de Queirós iria emprestar, de certo modo, as armas de sua inteligência e o milagre de sua verve. Sua vocação de artista, porém, haveria de sobrepor-se aos compromissos do orador (VELLINHO, 1945, p. 42-43).

Aceita-se, por meio desse trecho, que o brasileiro defendia um posicionamento mais artístico que político-revolucionário por parte de Eça, pois ele nota que a revolução do autor estava presente no seu estilo e na originalidade de sua linguagem do que em reflexões políticas e ideológicas. 
Se o vernáculo degenerara, se perdera a saúde e a naturalidade, era preciso extirpar-lhe as velhas infiltrações que lhe endureciam as juntas e lhe embaraçavam os movimentos. Então Eça de Queirós pegou com ambas as mãos esse corpo doente, sacudiu-o rudemente, esfregou-o dos pés à cabeça numa massagem que passaria à história, e quando se esperava que o paciente fosse soçobrar, ei-lo que salta da operação completamente restaurado, um sangue novo e alegre a borbulhar-lhe nas artérias. Um renascimento. A língua portuguesa deixara de ser um mostruário meticuloso e enfadonho de modismos anacrônicos. Era agora um instrumento dinâmico de expressão. Sob o estilo espaçoso e arejado de Eça de Queirós, ela multiplicou-se, ficou mais ampla, mais rica e mais viável (VELLINHO, 1945, p. 45).

Vellinho, ao aproximar a língua portuguesa ao corpo humano, retrata uma belíssima imagem de como Eça inaugura uma nova forma de se expressar pelo idioma português. Não destoa da opinião dos críticos que o antecederam ao colocar o estilo queirosiano em primeiro plano, o que busca comprovar o argumento de que a força do artista superara a sua análise social e, por meio do seu "estilo mais que pelo conteúdo político de sua obra, o grande romancista traduziu os impulsos de renovação que tanto o perseguiram” (VELLINHO, 1945, p. 47).

Moisés Vellinho ressalta que Eça vivera em um momento propício para revelar a inércia da sociedade portuguesa e usara a linguagem para retratar essa realidade de forma cômica. Essa ideia encontra respaldo no ensaio de Álvaro Lins, que também afirma que a visão crítica de Eça é guiada pela comicidade, como é possível verificar nas seguintes citações:

O antigo aluno de Coimbra, testemunha de tão furiosas arremetidas contra o convencionalismo satisfeito, acreditava seriamente na virtude terapêutica do desacato e estava convencido de que quanto mais violento ele fosse, quanto mais devastador, tanto mais fecundo nas suas consequências. Não admira, portanto, que o tivesse usado até ao excesso como meio de educação. Era uma estranha pedagogia, sem dúvida, mas já é tempo de reconhecer que as truculentas risadas de Eça de Queirós não escondem amarguras nem ressaibos de despeito. Seu riso é solto, claro, alegre mesmo. Nem parece de um corpo derreado por velha doença. $\mathrm{O}$ rumoroso negativismo do escritor denuncia sempre um forte 
cunho de jovialidade e é apenas um processo de cura social e política, à boa maneira de Juvenal. Nem cultura de pessimismo nem intuitos de pura destruição (VELLINHO, 1945, p. 35).

[Eça] Em cada um dos seus romances, ao lado da imaginação e dos recursos puramente artísticos do escritor, está presente o espírito de crítica, principalmente sob o aspecto de sátira e humour, que constituía a sua maneira predileta de tratamento de certas situações artificiais e de certos personagens ridículos da sociedade portuguesa (LINS, 1945, p. 50).

Para o primeiro, a provocação fora a principal arma de Eça contra a estagnação da sociedade portuguesa, o meio mais eficaz para renovar antigos pensamentos e, por isso, a defesa do desacato. Dessa forma, Vellinho defende a presença de um espírito formalmente revolucionário na obra queirosiana, em que “o espírito do tempo, sacudido pela revolução, subterraneamente convulsionado pelo ânimo de oposição a todas as tiranias, deveria encontrar na arte sua expressão legítima” (VELLINHO, 1945, p. 36). Em vista disso, ele verifica que Eça escolhera o Realismo por ser o melhor instrumento para conciliar o conteúdo estético e o conteúdo político.

Verifica-se, na crítica de Lins, que ele defende o posicionamento político em Eça, tanto na criação literária quanto na jornalística. Para ele, Eça assumira o seu lado social adaptando os problemas humanos da sociedade a cada forma de estilo que o tipo de texto exigisse: “As suas ideias, no romance, não são lançadas como teses, mas surgem no movimento do enredo e no jogo dos personagens, como expressões das realidades sociais ali expostas e desenvolvidas” (LINS, 1945, p. 56).

Compartilhando parcialmente da opinião de Gilberto Freyre, Moisés Vellinho e Álvaro Lins, o crítico-artista ${ }^{73}$ José Lins do Rêgo (1901-1957) também salienta o lado artista de Eça, todavia, diferente dos anteriores, justifica esse argumento ao encontrar na

\footnotetext{
${ }^{73}$ Nomenclatura de Alfredo Bosi, porém há outras nomenclaturas como "escritores-críticos” empregada por Leyla Perrone-Moisés, ou “críticos-poetas”, adotada por Afrânio Coutinho e João Alexandre Barbosa.
} 
obra queirosiana a presença predominante do lado humano de Eça e não pelo fato de o escritor não desenvolver teses como supõem os outros três.

Lins do Rêgo afirma que a humanidade está presente nos textos do realista no conflito entre aversão e amor a Portugal, fato que entra em choque com o Eça político que desejava fazer de seu país um retrato cruel e frio do ser humano.

De longe vai trabalhando com as suas faculdades criadoras aguçadas pela memória. O que existe como realidade de seu manancial, é a província portuguesa que ele pretende atravessar de alto a baixo com seus arrojos de romancista. Portugal está nas suas entranhas, em todos os seus momentos de grande escritor. E é assim, debaixo dessa imensa matéria viva querendo vencê-la que ele imaginava construir a sua obra (RÊGO, 1945, p. 132).

Nota-se que o brasileiro destaca o Eça artista e criador, pois, mesmo nas críticas mais duras que o autor realizara à Igreja, ao provincianismo, à educação das mulheres e ao casamento, estaria o lírico e não o revolucionário.

O que Eça de Queirós procurou como criador de personagens, é que as suas figuras tenham a vida que "nós temos, que não sejam aquelas imagens decóupes, de musculatura gelatinosa”. Queria ele agitar a massa humana com tal vibração que ela pudesse ser de verdade a carne e a alma que podiam perceber-se num Pére Goriot (RÊGO, 1945, p. 132).

Desse excerto, analisa-se que Lins do Rêgo, ao tomar a obra de Eça por esse viés, não ressalta como aspectos primordiais dela nem a crítica à realidade portuguesa e nem a construção caricatural dos personagens, como fizeram os seus contemporâneos, mas a forma simples, cuidadosa e humana com que Eça descrevera o povo português. $\mathrm{O}$ brasileiro admite que a escrita queirosiana poderia estar repleta "das leituras da Inglaterra e da França, mas o que o fazia vibrar como artista eram as coisas do seu reino” (RÊGO, 
1945, p. 135) e era, na sua pátria, que estaria “o grande e o pequeno Eça de Queirós” (RÊGO, 1945, p. 135).

José Lins do Rêgo defende a ideia de que Eça transitava entre duas realidades: a da metrópole e a do campo. Sobre isso, desenvolve o seguinte argumento:

Seria assim Eça o homem mais de uma metrópole, de uma cidade saturada de civilização do que da terra, do campo. Apesar de toda a sua formação aldeã e seus começos provincianos, de sua paixão pela poesia dos céus, dos rios e das árvores, que fazem pedaços de poemas em sua prosa, havia lá, no fundo da sua sensibilidade as raízes do "dandismo", do seu Jacinto, o seu amor ao conforto mais à moda (RÊGO, 1945, p. 130).

Muito próximo desses estudos, Astrogildo Pereira (1890-1965) segue a mesma linha de pensamento em seu ensaio ao afirmar que Eça era um escritor sem ideias, todavia, tenta inovar, ao analisar com mais profundidade, a produção jornalística de Eça, enquanto os outros analisaram a produção romanesca.

Astrogildo Pereira é categórico ao afirmar que, se Eça se consagrara como romancista, isso só se dera depois de sua passagem pela imprensa periódica. Ao comentar a colaboração do escritor na Gazeta de Portugal, como um momento significativo para a sua formação, observa:

O escritor estreante não se julgava um cronista, nem queria que o tomassem como tal. Mas enganava-se redondamente, pois o romancista e o cronista se manifestaram nele a vida inteira, como dois processos ou duas formas de expressão, diferentes, porém não inconciliáveis, daquilo que a meu ver constitui a característica essencial da sua personalidade de escritor: o satírico, isto é, o moralista (PEREIRA, 1945, p. 184).

Desse trecho, conclui-se que Astrogildo Pereira propõe uma leitura da obra queirosiana oscilando entre crônica e romance. O brasileiro ressalta que a maturidade da produção escrita de Eça acontecera quando conseguira dominar a fusão entre esses dois 
gêneros. Em vista disso, Pereira aponta a participação do autor n’As Farpas como de extrema importância, pois seria naquele momento que Eça "pôde exercer livremente o comentário dos acontecimentos, exercitando ao mesmo tempo os seus dons de escritor” (PEREIRA, 1945, p. 184). Todavia, de acordo com o ensaísta, é também ali que Eça teria percebido que “chegava ao fim o 'período bárbaro ${ }^{74, ” ~(P E R E I R A, ~ 1945, ~ p . ~ 185), ~ o ~ q u e, ~}$ para Ramalho Ortigão, fora um período de alegria ${ }^{75}$. Por causa disso, Astrojildo Pereira vê, nesse período, um Eça em “um riso que peleja... Aí está definido, como num autorretrato, todo o Eça de Queirós, romancista e cronista: o pelejador, o panfletário, o satírico, - o moralista, - que se bate ‘contra’ a Tolice em ‘prol’ da Razão” (PEREIRA, 1945, p. 185).

Observa-se que, do ponto de vista de Astrogildo Pereira, durante a transição de gêneros que passou a obra queirosiana, Eça mantivera a mesma postura de retratar a realidade da sociedade portuguesa, procurando tirar o povo lusitano da ignorância. Por isso que o brasileiro vê a passagem de Eça pela crônica como um momento importante para ajudar a construir e aprimorar o poder de observação do escritor.

O romancista estava feito, em plena posse dos seus recursos. Mas isso não lhe bastava; ele sentia dentro de si, como num transbordamento, a necessidade de se exprimir por algum meio estranho aos processos de criação romanesca, e esse meio seria normalmente a crônica (PEREIRA, 1945, p. 185-186).

Assim, argumenta-se que o brasileiro acreditava que Eça via, na produção de crônicas, uma possibilidade de dar maior movimento às ideias literárias, científicas, sociais e artísticas.

\footnotetext{
${ }^{74}$ Expressão de Eça de Queirós a respeito de sua produção nas Farpas publicado em Novas Cartas Inéditas de Eça de Queiroz, de 1940.

${ }^{75}$ Por isso o título Uma Campanha Alegre dado à reedição das crônicas das Farpas em 1890.
} 
Comentando a participação de Eça na imprensa, Pereira nota que, em nenhuma dessas publicações, Eça teria desenvolvido uma crítica social, mas crônicas de fundo sóciohistórico.

Nas Cartas de Inglaterra, o cronista preocupa-se de preferência com o que de mais grave e complicado apresentava a política inglesa: a questão da Irlanda, o bombardeio da Alexandria, as lutas no Afeganistão... Devemos reconhecer que Eça de Queirós, mesmo com as suas insuficiências de escritor político, fornece-nos, nas crônicas relativas a estes problemas, muita informação e muitos dados ainda hoje úteis ao estudo do processo histórico que caracterizou o período de ascensão do imperialismo britânico.

[...]

Talvez não haja cidade no mundo como Paris, em que as coisas mais graves aconteçam de cambulhada com as coisas mais grotescas, e às vezes se misturem de tal jeito que se torne difícil distinguir o que há de grave no grotesco ou o que há de grotesco no grave. Pelo menos era assim antigamente - e o nosso cronista, com o seu faro agudo de mestre da sátira, sentia-se ali como peixe dentro de água. Sobravam-lhe, pois, os assuntos e motivos para escrever as suas crônicas, que deliciavam os leitores do Brasil e Portugal (PEREIRA, 1945, p. 187-188; 191).

Na verdade, o que Astrogildo Pereira faz é resgatar a participação de Eça nos periódicos e provar que o escritor, mesmo produzindo crônicas jornalísticas, não abandonara sua veia artística.

E essa intuição de artista é que o tornava apto a apreender o sentido dinâmico de certos fatos, que viriam a ter enorme projeção no porvir, e que os observadores vulgares não viam, não compreendiam ou menosprezavam displicentemente (PEREIRA, 1945, p. 195-196).

Nota-se que o brasileiro formula uma teoria que explica a diferença da produção jornalística e romanesca do artista Eça: o escritor teria seguido uma mão dupla na construção dos personagens históricos e fictícios acompanhada pelo contraste entre realismo e idealismo romântico, uma vez que, quando Eça escrevia romances, acabava inserindo os antagonistas no campo do realismo e os protagonistas no campo do idealismo 
romântico e, quando escrevia crônicas jornalísticas, enfatizava nos protagonistas um “implacável realismo”, ficando o idealismo romântico para os personagens secundários.

O grande momento da crítica de Astrogildo Pereira está na forma como ele valoriza as crônicas de Eça, a ponto de considerá-las documentos fundamentais para a compreensão do escritor. Realça que o leitor das crônicas queirosianas está muito mais próximo do verdadeiro Eça do que aqueles que se restringem às leituras dos romances.

A posição do leitor frente os textos do escritor português ganha espaço especial no ensaio de Lauro Escorel (1917-2003), que desenvolve uma crítica sócio-histórica mais centrada nas relações entre obra e receptor ${ }^{76}$. Assim, ele produz uma análise que busca identificar o caráter sedutor na obra de Eça ao se colocar como um leitor queirosiano que teria sido seduzido pelo estilo do autor, cuja qualidade compara ao de grandes clássicos da literatura.

Lendo os seus romances, não nos detínhamos apenas diante dos seus lampejos de ironia e de graça, não nos atraía neles tão somente a inigualável fixação dos tipos ou a arte do paisagista, liricamente comovido diante da natureza; éramos sensíveis também à sedução das suas frases, cuja simplicidade, harmonia e ritmo acordavam em nós, egressos de Júlio Verne, Poison Du Terrail e Alexandre Dumas, o próprio sentimento de Beleza, o amor à forma plástica, colorida e vibrátil (ESCOREL, 1945, p. 158-159).

O ensaísta desenvolve uma concepção de que os textos de Eça são aqueles que mudam a visão de mundo de quem os leem, porque a obra queirosiana apresentaria um movimento de abertura à realidade, resultando no fim da ingenuidade, especialmente, do público jovem.

\footnotetext{
${ }^{76}$ Vale lembrar que, na década de 1940, não se encontrava formulada a de estética da recepção, criada pela Escola de Constança em meados de 1970, mas já havia discussões a respeito de uma sociologia da recepção, na França, iniciada com Gustave Lanson, em 1925.
} 
Um fato decisivo a preservou da morte: lêmo-la em plena adolescência, mergulhamos no seu mundo no momento psicológico exato, quando o espírito crítico acordava em nós, quando justamente começávamos a desconfiar dos homens e a pôr em dúvida o valor das convenções mundanas (ESCOREL, 1945, p. 157).

Esse posicionamento de Lauro Escorel, de 1945, encontra um fio teórico em Paul Valéry quatro anos antes, quando o francês afirmou que "certas obras são criadas para seu público. Outras criam seu público” (VALÉRY, 1996 [1ª edição, 1941], p. 17). No caso do brasileiro, a segunda relação seria ideal para ser adotada na leitura da obra queirosiana uma vez que Lauro Escorel vê, na produção de Eça, como formadora de espírito crítico, que educa o gosto para a literatura.

Outra publicação na qual ecoa as leituras da crítica seminal é a coletânea Eça de Queiroz. Documentário de uma comemoração, de 1947, organizada pela Diretoria de Documentação e Cultura de Recife (DDC). Esse volume é resultado também de um concurso de crítica literária e de ilustração tendo como tema Eça de Queirós.

Apesar de o concurso ter ocorrido em 1945, a publicação das produções dos primeiros colocados só ocorreu dois anos após a primeira efeméride. A demora da divulgação do volume é justificada pela DDC e pela Prefeitura Municipal de Recife da seguinte forma:

Dificuldades múltiplas, sobretudo a carência de material gráfico, retardaram excessivamente a publicação deste volume. O que, todavia, não lhe tirou a atualidade, uma vez que é acerca de Eça de Queirós, esse autor presente entre nós, que o volume reúne a contribuição de escritores novos, quase desconhecidos do grande público, de artistas que dão, ambos, a sua interpretação pessoal à figura e à obra daquele romancista (DDC, 1947, p. 3).

Além disso, a DDC acrescenta que o verdadeiro valor da publicação é a originalidade dos textos que colaboram para a formação da imagem do escritor no Brasil e, 
especificamente, na divulgação do carinho da população do Recife por Eça. Nos ensaios publicados, praticamente nada de novo surge e, no geral, constroem mais uma vez a imagem do dândi, do humanista e do artista. Tanta é a aproximação desse volume com a crítica seminal sobre Eça no Brasil que o livro termina com a transcrição da conferência proferida por Viana Moog sob o título “Variações em torno de Eça de Queiroz”.

Uma publicação que, em um primeiro momento, pareceria tomar outro rumo é Ideias de Eça de Queiroz (1946), de Francisco Werneck. Pelo título, dá-se a entender que finalmente, no Brasil, surgia uma crítica que traria novas leituras acerca de Eça, mas não é o que acontece. Além disso, coincidência ou não, um ano depois, em Portugal, Antônio José Saraiva publica um estudo com o mesmo título e, praticamente, com a mesma linha de raciocínio do brasileiro, isto é, ambos construíram um Eça sem ideias.

Werneck retoma toda a formação de Eça exaustivamente comentada anteriormente e reitera, em muitos momentos, no seu estudo, o fator "influência” na obra do escritor. Para ele, Eça fora totalmente “influenciado” por artistas portugueses e estrangeiros.

As influências pessoais notórias, ao campo da literatura, foram somente as de Ramalho, Antero, Oliveira Martins e com certeza Eduardo Prado, na sua maneira de considerar os Estados Unidos e o Brasil.

[...]

Mas as influências estrangeiras foram diversas e importantes: até 1870, os românticos; a partir daí, os realistas. A ação de Flaubert no espírito do escritor foi a mais duradoura: vem desde a forma apurada do Crime do Padre Amaro, das teses de Madame Bovary e da Educação Sentimental, inspiradoras do Primo Basílio e dos Maias, até as Lendas dos Santos onde se encontram traços semelhantes aos da lenda de Saint Julien l'Hospitalier. Balzac, Zola, Dickens, possivelmente Thackeray e Disraeli se acham em plano secundário.

Nas ideias filosóficas, religiosas e artísticas, são inegáveis as influências dos metafísicos alemães e mais tarde, preponderantemente, Renan, Taine, Darwin, Spencer, etc. Proudhon, que começara a ler em Coimbra, constantemente citava, até em seus últimos artigos, como o fez ainda no perfil de Eduardo Prado, que é de 1898 (WERNECK, 1946, p. 117-118). 
Da forma como Werneck aponta essas possíveis “influências” em Eça, ele acaba produzindo uma crítica que diminui o valor da obra queirosiana, ao ressaltar que o escritor precisava (re)criar com base em ideias já formuladas.

No Crime do Padre Amaro, o plano da obra foi traçado conforme as diretrizes gerais dos livros do chefe da escola naturalista; mas a tese se desenvolve com independência completa, sem que se possa vislumbrar qualquer gênero de imitação. Já no Primo Basílio há evidente analogia entre a sua tese e a de Madame Bovary, conquanto muitos detalhes importantes ponham mais em destaque a ideia do combate social em Eça, pela normalidade dos tipos principais, que se apresentam, desse modo, como vítimas exclusivamente da educação e do meio, ao passo que, em Flaubert, os tipos equivalentes são casos excepcionais, pelo exagero evidente de certos caracteres pessoais: em Ema, a exaltação sentimental inata e, em Carlos, o ridículo muito próximo da cretinice. Balzac está também presente, não na forma ou no desenvolvimento da ação, mas nos detalhes psicológicos. Zola só lhe oferece sugestões secundárias. Mas percebe-se, já no Primo Basílio, uma nova influência poderosa - a dos escritores ingleses, notadamente Dickens (WERNECK, 1946, p. 51).

Ele faz também uma leitura do conjunto da obra de Eça, privilegiando a relação entre a ideia presente na obra e o modo como ela é veiculada, retomando o debate entre "forma” e "fundo". Para o brasileiro, Eça iniciara uma trajetória pelas ideias a favor de uma campanha política e social, quando ele passara a apontar a miséria da população, o falseamento dos costumes, a corrupção e a decadência religiosa.

Até os trinta anos de idade, ou vivendo em Coimbra, em Lisboa ou Havana, ou ilustrando seu espírito durante as longas viagens que empreendeu, pudera adquirir os conhecimentos básicos de fatos sociais e dos ambientes em que se movera, essenciais à fatura de seus livros; depois, em New-Castle, vivendo isolado, entregue à meditação, refugiado na sua arte, não só aprofundou seus estudos da alma, como teve tempo e pôde dedicar com exclusivo carinho ao polimento da forma admirável com que revestia suas concepções (WERNECK, 1946, p. 50). 
Quando parecia que o estudo de Francisco Werneck engendraria pela defesa do conteúdo na obra de Eça, ele anda em círculos e reescreve as linhas da crítica seminal ao apontar somente para o artista e não para o intelectual.

Retomando um pouco do que foi dito até agora os ensaios de Olívio Montenegro (1896-?) e de Luiz Delgado (?-?) fazem a análise da ação dramática, que teria origem em traumas que Eça teria sofrido e transferido para a sua produção escrita. Para o primeiro, a obra queirosiana é resultado da “observação e da experiência pessoalmente vivida” e da “imaginação criadora” (MONTENEGRO, 1945, p. 109) do autor. Pensando, dessa forma, o primeiro ensaísta faz uma ligação entre essa postura de criar de Eça com o Romantismo, procurando destacar, na produção fictícia do autor, o caráter novelístico.

A visão persistente do detalhe leva sempre a certo pessimismo de imaginação e de ideia, a uma involuntária atitude de combate e de crítica, a um minucioso luxo de análise, pois só um instinto dramático muito forte pode produzir um interesse romântico vivo e duradouro (MONTENEGRO, 1945, p. 11).

Além disso, Olívio Montenegro compreende que esse aspecto de não-lugar da obra de Eça, por transitar entre as estéticas romântica, realista e naturalista, é ocasionado por um motivo psicológico do autor que, mesmo aderindo às características do Romantismo, escolhera o Naturalismo para conseguir satisfazer sua vontade de "valorizar o detalhe, para exagerá-lo, multiplicá-lo, sublimá-lo em pitoresco” (MONTENEGRO, 1945, p. 111).

Quando na obra de ficção se exagera o minúsculo ou o acidental pelo excesso de análise, e atrás de refazer a natureza em modelos que seriam de um interesse mais científico do que artístico, a observação, por menos que pareça, perde sempre aí o melhor da sua elasticidade para ficar em relação à liberdade de conhecer e julgar. $\mathrm{O}$ caso de Eça, entretanto, é diferente. $\mathrm{Na}$ sua preocupação do detalhe não se descobre o especiosismo científico dos naturalistas [...] E por isto o que nele perde a observação em efeito minuciosamente fotográfico de representação, ganha em intensidade e colorido de visão (MONTENEGRO, 1945, p. 112). 
Nesse trecho, observa-se que Olívio Montenegro considera a produção literária de Eça como uma pintura que reproduz e que recria a realidade, colocando o autor no campo da fantasia e não no da imaginação contrariando muitos críticos queirosianos que o antecederam. Assim, para o brasileiro, a obra de Eça fora dominada pelo "ar de novela" (MONTENEGRO, 1945, p. 112) tanto a produção ficcional quanto a jornalística e epistolar. Ao fantasiar a realidade, de acordo com Olívio Montenegro, Eça empregaria a comicidade, pois “o riso foi a arma de crítica de que mais se serviu Eça de Queirós, e que ele próprio estimava de uma força de demolição inestimável” (MONTENEGRO, 1945, p. 114). Assim, Eça usaria a ironia porque ela "não está propriamente na atitude de quem observa para o sutil prazer de descobrir, mas de quem observa para a satânica alegria de condenar” (MONTENEGRO, 1945, p. 115).

Nota-se que Montenegro compreende a obra romanesca de Eça, em sua maior parte, voltada para a moralidade incluindo aí O Crime do Padre Amaro, O Primo Basílio, O Mandarim, A Relíquia (entre outros). Por isso o brasileiro teria realizado uma aproximação entre a função moralizante da literatura do escritor português com a produção caricatural dos personagens. Para o crítico, a crítica caricatural só alcançaria um resultado: desvendar a sua principal personagem, Portugal. Olívio Montenegro elege Os Maias como o romance melhor concebido pelo escritor português, apesar do que vê como problemas:

Os Maias são uma obra mais expressiva, a obra em que mais ficam à mostra as suas qualidades mais fortes, tanto quanto os seus defeitos de escritor. E o romance onde o seu talento pictural, a sua penetração psicológica, a sua força descritiva se exercem em cenas sucessivas com mais surpresa, e também onde as suas prevenções de espírito, se abrem em críticas da mais premeditada caricatura, não ganhando aí a sua ironia em mordacidade senão para perder em finura e onde o seu secreto senso moralista toma em certas páginas um acento mais ostensivo (MONTENEGRO, 1945, p. 117). 
Todavia, de acordo com o brasileiro, não é a caricatura a maior qualidade dos personagens, mas o traço de humanidade que eles contêm. Segundo o crítico, isso ocorre devido ao fato de Eça haver recebido duas influências: o Naturalismo e o Romantismo. Deles, retirara a observação detalhada e idealista, respectivamente, da realidade, pintando-a como ele a sentira. Quem desenvolve essa ideia também é Álvaro Lins, que observa uma força evocativa em Eça, uma vez que o autor retomaria a história portuguesa para compensar o presente.

Montenegro nota que o gosto pela dramatização do passado encontra-se em $A$ Relíquia, A Ilustre Casa de Ramires e O Mandarim, (re)inventando a realidade em uma preocupação com o dizer, usando a sensibilidade de um artista e não o relato de um cientista.

\begin{abstract}
Não há escritor - salvo os que fazem das mãos pés, e escrevem como quem escarva - que, para exprimir uma ideia ou uma imagem, não procure, entre muitas frases ou palavras, aquela que pareça a mais harmoniosa, a mais musical. Acontece porém que essa harmonia e essa música são impossíveis quando o fato não se encontra com a ideia, e a ideia não se encontra com a sua forma real, precisa, verdadeira e a que somente conduz a sensibilidade e o gosto individuais (MONTENEGRO, 1945, p. 126).
\end{abstract}

Para Montenegro, Eça buscara a perfeição da observação e da escrita, isto é, o máximo de expressão em arte. Isso justifica, conforme o estudioso, que o autor sofria algumas deficiências de temperamento que o conduziam a uma visão unilateral da realidade.

Verifica-se que a crítica de Olívio Montenegro oscila entre aquela que encara o texto literário como uma projeção psíquica e individual e outra que projeta no texto uma preocupação coletiva.

Luiz Delgado também compartilha desse posicionamento crítico e afirma que muito da personalidade de Eça está presente na sua produção. Nesse caso, ele aponta a educação 
religiosa como tema recorrente nos textos queirosianos. Delgado considera que Eça estava dividido entre os sentimentos de revolta e piedade. Esse dualismo transpareceria nos personagens ecianos como um retrato da condição espiritual do escritor.

Segundo o brasileiro, Eça transitara no tema religioso entre o que existia (a crítica e a sátira à sociedade clerical) e o que via (afinidades e simpatias por figuras religiosas), uma vez que ele "viu apenas que a religião não consiste nas cavilações do padre Negrão ou nas estultices da tia Patrocínio, mas inspira a bondade, a elevação, a pureza” (DELGADO, 1945, p. 236).

Acerca da narrativa queirosiana, Luiz Delgado nota a presença da psicologia do autor que apareceria em dois momentos: num primeiro momento, em que a visão de Eça perante a sociedade religiosa em Portugal está reduzida a uma "irritação suspeita [...] semeando aqui e ali julgamentos de valor, juízos próprios que transpõem os limites da arte e penetram nos campos da objurgatória e do panfleto” (DELGADO, 1945, p. 233); e, num segundo momento, em que a visão do escritor clareia e passa a ver melhor, notando que além de padres infiéis existia "também almas sedentas de elevação e perfeição" (DELGADO, 1945, p. 233). Mesmo assegurando que Eça tinha compreendido que não só o que via existia, Luiz Delgado observa que há limitações na apresentação de temas religiosos por parte de Eça de Queirós, pois, para o brasileiro, toda religião segue três premissas:

A noção de existência de um ser superior ou supremo; a de uma relação de dependência do universo para com ele; e a da possibilidade e do dever de entrar o homem em comunicação com Ele pela observância de uma lei ou pelo exercício de um culto (DELGADO, 1945, p. 233).

Eça aparentaria ignorar tais noções, já que não seria compreensível como o autor não fizera com que seus personagens religiosos não se sentissem culpados pelos atos 
contra a religião e, em vez disso, penalizava a consciência das outras personagens, por exemplo, a de Amélia. Sobre isso, Delgado salienta:

Parece que só uma razão pode explicá-lo: a visão puramente social da vida religiosa olhando a religião menos como um fato espiritual do que como um costume coletivo, era, ainda mais, dominada por um partidarismo, por uma oposição talvez inconsciente à figura e à ação do sacerdócio. O sentimento religioso que não trouxe em si mesmo, Eça de Queirós não soube também vê-lo nem colocá-lo nos outros (DELGADO, 1945, p. 234-235).

Antes de Luiz Delgado, Álvaro Lins já havia ponderado sobre o posicionamento de Eça diante de assuntos religiosos e também detectado que o escritor português tinha mais uma preocupação social e estética do que religiosa. Todavia, Delgado vê que, por forças misteriosas, Eça mudara o seu posicionamento nos últimos livros e compreendera que havia uma figura a admirar: Jesus Cristo.

Na verdade, o brasileiro acaba por defender a ideia de que Eça acreditaria na mediação entre o homem e Jesus para atingir a eternidade, visto que o romance como $A$ Relíquia retrata o sentimento de solidão e insegurança que dominam o homem e que podem ser amenizados pela imagem de Cristo.

Enfim, Luiz Delgado retoma, em seu ensaio, a discussão em torno da situação do homem do século XIX frente à religião, uma vez que o indivíduo novecentista estava propício a repudiar os mitos, as lendas, o sobrenatural como o fazia Eça. Consegue aproximar Eça da religião, pois entende que, para o escritor, havia a necessidade da existência real e, por isso, ele teria escrito a vida dos santos, isto é, de pessoas que existiram e que foram santificadas. Assim, observa-se que a religiosidade do autor levantada por Delgado se aproxima da atitude do apóstolo São Tomé à respeito da fé: "ver para crer”. 
Dessa forma, ele e os outros que desenvolveram uma análise sócio-histórica acerca da obra de Eça concluíram que o autor é fruto das relações de produção, isto é, os textos do escritor são resultado da visão de mundo do artista. E eles acreditam que a construção da realidade parte do viés imaginário, prevalecendo, assim, sempre o domínio estéticoliterário do escritor, aspecto que dá continuidade à crítica seminal.

Em uma espécie de montagem de um quebra-cabeça, esses estudos agrupados na crítica sócio-histórica relacionam-se e complementam-se no intuito de retomar o retrato do dândi talentoso que os textos fundadores divulgaram e instituíram como única verdade.

\section{0 biografismo de Eça de Queirós}

O biografismo volta com força e mais uma vez a vida do autor aparece em primeiro plano nos estudos queirosianos brasileiros como aconteceu na crítica seminal. Diversas publicações $^{77}$ entre as efemérides deram continuidade a essa abordagem crítica, porém tomamos alguns exemplos dessa releitura com os livros Retrato de Eça de Queiroz (1945), de José Maria Bello (1885-1951) e Roteiro de Eça de Queiroz (1946), de José Stênio Lopes (1916-), além de dois ensaios do Livro do Centenário intitulados “Amigos brasileiros de Eça de Queiroz”, de Otaviano Tarquínio de Sousa (1889-1959) e “Eça de Queiroz visto através de suas cartas”, de Lúcia Miguel-Pereira (1901-1959).

Nas publicações em formato de volume, Bello aparece em primeiro lugar e apresenta duas leituras para formar o retrato de Eça de Queirós. A primeira é reservada ao que considera o "Retrato político de Eça", no qual descreve, adotando uma sequência cronológica, as etapas que teriam formado o seu "espírito público”. Tal espírito determinaria, na visão de Bello, a forma patriótica como Eça concebera a vida política

\footnotetext{
${ }^{77}$ Cf. Quadro cronológico das publicações em formato de livro no Brasil durante o século XX anexado neste trabalho.
} 
portuguesa, identificando ali com certo revanchismo de quem não conseguiu ingressar naquele universo como gostaria.

Maldizendo a política, satirizando cruelmente os políticos da sua época, ou deles sorrindo com desdém, não o abandona jamais a obsessão da política. Parece por vezes que há no seu rancor contra os políticos uma sombra qualquer de despeito; não se despreza com tamanha constância e veemência senão o que se desejou e não se conseguiu ou o que, brutalmente, desencantou certos ideais íntimos (BELLO, 1977 [1 $1^{\mathrm{a}}$. ed. 1945], p. 1). ${ }^{78}$

Para o estudioso, a “obsessão” do autor pela política alcançara o extremo do patriotismo e sobre isso comenta que o realista lutara “contra a decadência de seu país e da sua gente” (BELLO, 1977 [1 ${ }^{\mathrm{a}}$. ed. 1945], p. 1). E acrescenta a isso que nem a aguçada sensibilidade estética do escritor fizera desaparecer o ímpeto político presente, principalmente, durante a atividade jornalística.

Bello formula essa hipótese por intermédio da observação que realiza da presença recorrente de figuras políticas na obra queirosiana, que são "sempre duramente caricaturadas, incapazes, hipócritas, ímprobos, cúpidos, grotescos, mal-educados, sem nobreza e sem patriotismo, enfim, o que há de mais lamentável” (BELLO, 1977 [1ª. ed. 1945], p. 5). No uso de adjetivos de caráter pejorativo, o crítico acredita piamente que Eça não perdia oportunidade para criticar os políticos e o fizera mesmo estando distante do mundo da política. Percebe que a preocupação política de Eça surge como um dos pilares de seu edifício literário e afirma que o autor seguira a estética realista, porque somente por meio dela conseguiria reconstruir a vida política de Portugal.

O crítico considera que foi com As Farpas que Eça elaborara pela primeira vez uma verdadeira "literatura de combate” e acrescenta que lhe faltara, no entanto, "a vocação

\footnotetext{
${ }^{78}$ Não houve mudança da $1^{\text {a }}$ edição, de 1945 , para a $2^{\text {a }}$ edição, de 1977. Prova disso também está na nota publicada pela Companhia Editora Nacional que anuncia que o truncamento que existia na primeira publicação retorna na publicação da década de 1970 devido à perda dos originais em um acidente.
} 
inata de Ramalho Ortigão" (BELLO, 1977 [1 . ed. 1945], p. 10; 11). Embora Bello enxergasse na produção jornalística do autor certa força política, justifica que o lado pedagogo de Ramalho lhe favorecia "para persistir na campanha, sobretudo quando esta passaria da destruição para a construção”, pois

Eça, temperamento de artista, antidogmático fundamental, como quase todos os homens de alta sensibilidade estética, não podia enquistar-se definitivamente nas formas secundárias do jornalismo político. O romance, a novela, o conto, eis, pois, o seu destino, que o exílio, a distância das coisas e figuras da pátria acentuariam, porque lhe permitiriam mais larga perspectiva e, por consequência, melhores condições para a evocação das realidades observadas ou pressentidas (BELLO, 1977 [1 ${ }^{\text {a }}$. ed. 1945], p. 11).

Essa leitura de Bello sobrevive, de certo modo, em ensaio escrito por Benjamin Abdala Júnior, em 2001:

Na distância do repertório crítico de hoje, sabemos que o escritor não representa diretamente a realidade, mas opera a partir das formulações discursivas sobre ela. Além disso, o olhar que vê e observa essa realidade é conceitual e se prende à discursividade dos campos de conhecimento da cultura. Entre essas formulações culturais, figuram os elementos estruturais da narrativa, que se dispõem como verbetes de um dicionário - um repertório a ser apropriado pelo escritor. E, dessa forma, o autor realista, preocupado em fazer da literatura uma forma de consciência de uma realidade que precisaria ser transformada, deveria estar imbuído de um princípio que pudesse ensejar ação (político-social), sem tolher a imaginação criadora (ABADALA JÚNIOR, 2001, p. 3839).

A perspectiva tomada pelos dois estudiosos se aproxima na medida em que ambos estabelecem relações entre crítica social e política e gêneros literários na obra do escritor português. E essa ideia já tinha sido anteriormente evocada pelo próprio escritor na célebre citação de A Relíquia: "Sob a nudez forte da verdade, o manto diáfano da fantasia". Para ambos os críticos, o que sobressai é o ímpeto artístico do escritor.

Bello reconhece e assume essa concepção levantada pelos primeiros queirosianos de que Eça mudara de postura frente aos problemas de Portugal quando entrara em contato 
com outros paradigmas culturais. As viagens ao Oriente, à América e à Europa representaram uma guinada no processo da escrita jornalística e, consequentemente, da literária, perante a realidade, notando que ele, ao se aproximar de situações iguais ou mais graves do que as enfrentada por Portugal, percebera que os vícios e os erros não dominavam exclusivamente a sua pátria.

Quando mais tarde Eça viveu na Inglaterra vitoriana e na França da Terceira República, muito se abalaram as suas ilusões, sem embargos de sempre lhe afigurarem perfeitas as duas nações ribeirinhas da Mancha, em paralelo com os Estados Unidos, trepidantes e monstruosos, que ele visitara ao tempo do consulado de Havana... O Reino Unido, no período dos consulados “ecianos” de Newcastle e Bristol, isto é, de 1875 a 1890, estava no apogeu de sua força e grandeza (BELLO, 1977 [1. ${ }^{\mathrm{a}}$. ed. 1945], p. 19).

É possível verificar, no estudo do crítico, que essa ideia comum aos queirosianos partiu do momento em que perceberam na obra de Eça um redirecionamento frente à realidade, que não era mais somente a portuguesa, mas também das outras nações. Isso está posto em Bello quando este compreende que Eça recuperara, em sua obra literária, além do retrato político de sua época, o pensamento filosófico-científico que dominava a Europa na segunda metade do século XIX.

Para Bello, a sátira da "Primeira Fase” da obra surge para reeducar a sociedade portuguesa em um processo de desvelamento do real, e a sutileza da "Segunda Fase", composta por A Cidade e as Serras, A Ilustre Casa de Ramires e da vida dos santos, surge para amenizar as críticas ferrenhas da primeira fase. Essa distinção entre a primeira e a segunda fase tem eco ainda hoje, quando é possível ler em Luiz Fagundes Duarte que:

[Eça] Deixando de lado as lições e abandonando o pragmatismo, sai da posição de sábio e de mestre e, valorizando a ambiguidade, acentua o aspecto lúdico de sua literatura, revelando a perspectiva de que é impossível afirmar um sentido definitivo, dado o caráter fluido da linguagem (DUARTE, 1997, p. 292). 
Lembrando que Bello não cita o jogo do fingimento do "eu” diante da realidade, como fez Duarte, mas valoriza o caráter ameno e tranquilo do escritor que percorreria os seus últimos textos.

A única ligação que Bello vê da "Primeira Fase" para a "Segunda Fase" é a imutável postura patriótica de Eça. Mesmo nas críticas mais mordazes, Eça manteria seu apreço pela pátria portuguesa. Na realidade, o que Bello ressalta é que Eça considerava que das críticas viria a remissão dos vícios, ou seja, o crítico assinala que o autor criticava não por desprezo pela sociedade portuguesa, mas para movimentá-la, para que saísse do provincianismo. Porém, ao final da vida, o escritor passara a escrever dominado pelo saudosismo.

A ironia impiedosa, que tanto lhe serviria para conter ou corrigir as emoções possíveis, sucede uma suave e confessada tolerância. Conservando e aprimorando as próprias qualidades de escritor plástico, isto é, de paisagista e colorista, e cada vez mais seguro dos recursos técnicos da arte de escrever, adquire o seu estilo como que uma ressonância nova, música interior que lhe faltava, doce pátina de melancolia, a adoçar os contornos tantas vezes duros da frase pitoresca e incorreta, tão pouco preocupado de cacofonias. A saudade poetiza-lhe cada vez mais as imagens da pátria (BELLO, 1977 [1ª. ed. 1945], p. 31).

Nota-se, nesse excerto, que Bello acredita na mudança do temperamento de Eça, que, ao "poetizar" a realidade, dera margem para que o interpretassem como mais tolerante frente a ela. Mais do que isso, quando o crítico cita a plasticidade de Eça no uso dos recursos da escrita, entende-se que a produção da "Segunda Fase” se aproxima da ideia de artifício, do fingimento de que falava Duarte. Eduardo Lourenço (1997) retoma essa ideia de forma mais complexa, salientando que Eça “cedeu também ao reflexo da evasão, de fuga diante de um mundo real onde os sonhos tinham tanta dificuldade em encarnar” (LOURENÇO, 1997, p. 714), diferentemente da “Primeira Fase”, que considera como delineadora do retrato fiel daquela época. 
Assim, observa-se que Bello sintetiza a formação política de Eça de maneira otimista ao notar que o escritor português, independentemente do momento de sua vida, nunca deixara de acreditar na "marcha civilizadora do mundo" (BELLO, 1977 [1 ${ }^{\mathrm{a}}$. ed. 1945], p. 32) e muito menos na literatura. Dessa forma, conclui que Eça não criticava só Portugal, mas o decadentismo ${ }^{79}$ da civilização de sua época.

A segunda etapa de seu estudo é reservada ao que se considera o "Retrato literário de Eça”. Nesse momento, o crítico brasileiro dialoga com a forma como a psicologia foi estilizada para delinear a imagem do escritor. A respeito disso, Bello destaca que não há nos textos de Eça “direta ou indiretamente, qualquer referência comovida à sua gente e nem tampouco qualquer evocação da sua infância”, no entanto, a sua condição de bastardo “não deixaria de influir na sua concepção geral da sociedade” (BELLO, 1977 [1ª ed. 1945], p. 34-35).

Bello, além de rejeitar o que a crítica psicologizante queirosiana construiu até 1945, apresenta uma nova leitura da personalidade de Eça, fundada em suas leituras. Enfatiza que Eça tinha gosto pela descrição das normas da moral burguesa da família por ter sido leitor assíduo do filósofo francês Pierre-Joseph Proudhon. Dessa maneira, compreende que a personalidade literária de Eça não fora construída pela influência do meio familiar, visto que esse ambiente fora "secundário na história do seu espírito” (BELLO, 1977 [1ª. ed. 1945], p. 37).

Embora iniciasse sua ideia sobre a formação literária de Eça de forma inovadora, Bello recai na crítica queirosiana adotada por seus contemporâneos ao afirmar que Eça mostrara uma formação intelectual "deficiente”.

\footnotetext{
${ }^{79}$ Cf. MACHADO, Álvaro Manuel. Eça e o decadentismo: uma estética da ambiguidade. In: MINÉ, Elza (org.). Anais do III Encontro Internacional de Queirosianos: 150 anos com Eça de Queirós. São Paulo: FFLCH/USP, 1997, p. 45-51.
} 
Eça de Queirós não foi nunca nem revolucionário e nem contrarrevolucionário. Incerto e confuso o seu pensamento político, como é comum em tantas inteligências lúcidas de fundo diletante e tendência artística. Sem embargo do seu vivo espírito público, a sua visão do mundo era essencialmente literária. Ele mesmo confirma com a habitual franqueza a sua incapacidade de discernimento filosófico. Poderia acrescentar com igual exatidão - de claro julgamento político. $\mathrm{O}$ liberalismo político irritava-o, sobretudo pela banalidade da vida em que podia florir um país nas condições de Portugal [...] (BELLO, 1977 [1ª ed. 1945], p. 43).

Compreende a importância da formação política na construção do artista, mas considera realça que a grande marca do autor não está no seu posicionamento político e sim no seu posicionamento como homem das letras. Bello destaca que foi conhecendo o homem, principalmente, por meio do acesso às cartas trocadas entre o escritor com familiares e amigos, que passou a enxergar Eça de uma maneira mais humana e menos divina.

O ensaio de Lúcia Miguel-Pereira complementa essa visão de Bello da importância de se estudar as cartas de Eça, uma vez que, para ela, a análise profunda da obra literária só é possível considerando a sua totalidade:

separar uma obra do seu autor, é desprezar-lhe a melhor, embora não única, fonte de interpretação [...] Ao lado do seu valor estético absoluto, toda a criação literária possui um valor moral relativo, condicionado pelas circunstâncias em que foi elaborada, pelo tempo, pelo meio (MIGUEL-PEREIRA, 1945, p. 263).

Para Lúcia Miguel-Pereira, o estudo da vida do autor só tem serventia para a crítica se ela tiver ecos na obra, o que ela resume como aspectos psicológicos, pois são estes que influem na literatura. Para ela, “como todo artista autêntico, Eça de Queirós tem o seu mistério, alguma coisa de imponderável, que talvez possa ser vislumbrado pelo confronto entre os livros que escreveu e o homem que foi” (MIGUEL-PEREIRA, 1945, p. 264). 
Verifica-se, no estudo da brasileira, que os escritos de Eça são identificados com o cidadão Eça a ponto de o artista dominar o homem na primeira fase, em uma espécie de “mimetismo provocado no homem pelo literato” (MIGUEL-PEREIRA, 1945, p. 266). Para ela, a literatura queirosiana do início da carreira do autor tinha de ser de impacto, ousada, para ilustrar a reforma literária que tomava conta da nova geração. Traz à tona a reflexão sobre a função do artista e como é angustiante essa atividade, pois, de um lado, ele busca uma vida que não foi a dele, buscando fixar sua existência.

Há por isso qualquer coisa de trágico, de angustiante, na atividade do artista. Angústia de que sofreu evidentemente Eça de Queirós. Exasperado pela ameaça constante da tuberculose, o amor da vida, por um processo subconsciente de compensação, se confundia nele com a paixão literária (MIGUEL-PEREIRA, 1945, p. 266-267).

Lúcia Miguel-Pereira acredita que a própria imagem de Eça somava-se ao seu projeto literário: o seu “dandismo”, o que representaria o novo comportamento do português (bem vestido, um ser pensante, um ser que escreve). Para ela, Eça não ousara mais nos elementos políticos e sociais, porque o artista dominara o homem, fato que refreara os ímpetos do escritor.

Observa-se que traça um perfil de um homem que cede a sua vida para a arte e, para conhecer mais do homem por trás do artista, faz uma breve apresentação da correspondência particular do escritor. Na leitura que faz das cartas, levanta dois traços significativos da personalidade de Eça: o primeiro, o amor que tinha por Portugal; o segundo, a humildade de seu espírito. No primeiro traço, nota-se que a brasileira resgata o saudosismo de Eça por sua pátria, pelo fato de sempre ter estado mais ausente do que presente. No segundo traço, percebe-se que apresenta as dúvidas de Eça em relação à sua vocação. 
Lúcia Miguel-Pereira afirma acreditar nas informações obtidas mediante a correspondência do autor e faz isso pensando em uma parte da crítica queirosiana que defende o argumento de que tudo não passava de um “jogo”, um marketing pessoal do autor.

Observa-se que Bello concorda com Lúcia Miguel-Pereira e salienta que o público brasileiro só conheceria as ideias, as “influências”, as angústias, as vivências de Eça na leitura da correspondência. Se em Portugal houvera uma recusa inicial a essa inovação; no Brasil, houvera uma aceitação imediata. José de Alencar já iniciara esse movimento de inovação da linguagem literária e, portanto, o público brasileiro já estava familiarizado com essa postura.

O ensaio de Otaviano Tarquínio revela que a grande aceitação de Eça no Brasil ocorrera devido à proximidade e ao aconchego que os leitores brasileiros sentiram tanto na leitura dos textos jornalísticos quanto na leitura das obras literárias. Para o brasileiro, a figura de Eça e a preocupação que ele tivera com o tema da amizade foram elementos essenciais para que fosse aceito não somente entre os leitores comuns, mas também pelos letrados.

Tarquínio faz um paralelo entre as amizades dos personagens queirosianos com os verdadeiros amigos do escritor e compreende, por meio da leitura das cartas trocadas entre Eça e seus amigos, que eles mantinham uma relação fraternal. Esse quadro da amizade de Eça não era novidade e muito menos a sua intimidade com o brasileiro, Eduardo Prado.

No resumo que Otaviano Tarquínio faz da amizade entre o autor português e Eduardo Prado, aparece o lado metropolitano de Eça, que, segundo ele, seria o responsável pela visão estreita do escritor sobre o Brasil, já que se baseava em um único tipo brasileiro. 
Eduardo Prado na verdade representava um tipo pouco comum de brasileiro; e sobretudo de brasileiro viajante ou viajado. Ao conhecê-lo, não descobriu Eça de Queirós nenhuma das figuras mais fáceis de encontrar na Europa [...] (SOUSA, 1945, p. 242).

A forma como Tarquínio relata a amizade entre Eduardo Prado e Eça é o resultado da aceitação do português colonizador perante o brasileiro-colonizado, como se o brasileiro passasse por um teste e fosse aprovado. Todavia, a imagem do brasileiro na vida e na obra de Eça é marcante e é essa ligação entre eles analisada no ensaio.

Para Otaviano Tarquínio, Eduardo Prado instigara o gosto pela tradição em Eça (passado, religião), o que apareceria na última fase do autor. Sobre isso, Tarquínio desenha o quadro de uma amizade que vira "influência”, sendo ambos descritos pelo ensaísta como defensores da monarquia e contra o republicanismo que dominava a América. Aparece aqui o Eça conservador, que muita polêmica gerará na segunda metade do século XX.

Tarquínio ressalta o apoio mútuo entre eles em assuntos políticos e pessoais e como tudo isso transparece em publicações em periódicos ou cartas íntimas. Faz um relato de uma “amizade generosa” que chegara até a morte de Eça. Uma amizade que se desdobra em outras, também com brasileiros que conheceram o realista português por intermédio de Eduardo Prado, como Paulo Prado, Domício da Gama, Barão do Rio Branco, Martinho Botelho, Magalhães de Azeredo, Ferreira de Araújo, Olavo Bilac.

Esse lado afetivo e humano de Eça desenvolvido por Otaviano Tarquínio, que já fora delineado no grupo de textos de análise sócio-histórica, também aparecera em Bello, que focalizou mais o lado das respectivas produções escritas do que o lado artístico, apesar de haver um paralelo entre a sensibilidade estética e a sensibilidade humana como é possível verificar na argumentação do brasileiro.

Na apresentação da carreira literária do autor português, Bello resgata a polêmica entre "forma" e "fundo" afirmando que as produções folhetinescas do autor são as únicas 
que apresentam uma unidade de pensamento. Mas, mesmo desenvolvendo essa ideia inovadora para a época, também reproduz o pensamento crítico de seus contemporâneos.

A forma deixa mais entrever o futuro escritor do que a substância. Desprende-se da nebulosa num esforço para viver a sua própria vida. Muito distante, entretanto, do pitoresco e da graça que o imortalizariam. Gramática francesa, construção francesa, galicismo, barbarismos de toda natureza. Incerto ritmo. Pobreza de vocabulário, cacofonias, ecos, todos os vícios de linguagem, aos quais o seu ouvido teria sido sempre mais ou menos rebelde. Abundâncias de adjetivos e de exclamações. Abuso inconsciente das silepses, das elipses, das sinédoques e das antíteses (BELLO, 1977 [1ª. ed. 1945], p. 70).

Nesse trecho, Bello ilustra o estilo linguístico de Eça que ainda dava seus primeiros passos. O crítico revela que a inovação da linguagem instituída pelo autor fora motivo de imitação de muitos literatos brasileiros. Com isso, compreende-se que o estudioso considera o manuseio das palavras como o ponto forte na obra queirosiana, mesmo na produção poética do início da carreira de Eça, analisada por Bello como sendo detentora de qualidade inferior à do romancista que surgiria.

O brasileiro nota que nos romances O Crime do Padre Amaro, O Primo Basílio e Os Maias, o escritor já conseguia mostrar "as suas grandes virtudes. Principalmente, a força evocativa. Ninguém antes ou depois dele soube fazer tão presente, tão vivo em língua portuguesa, um canto da natureza, uma cena de rua, um quadro de interior” (BELLO, 1977 [1 ${ }^{\text {a }}$ ed. 1945], p. 81). Embora Bello levantasse aspectos positivos da "Primeira Fase" literária de Eça, o crítico, aproximando-se da leitura de Machado de Assis, também aponta a presença do que ele considera “defeitos” da escola literária a qual estava filiado. Assim, para Bello, os romances da "Primeira Fase”, a realista propriamente dita,

ressentem-se todos do "curto fôlego" imaginativo do seu autor, faltoulhe sempre o grande sentimento dramático, a capacidade inventiva. Repetem-se-lhes as situações e os personagens como se lhes repetem as frases, os efeitos espirituosos e, mesmo, os pequenos tiques e cacoetes. A técnica da sua escola permite-lhe que, nos romances, à margem do 
episódio central, se alongue, por vezes excessivamente, em cenas secundárias e na descrição de paisagens que, afinal, mínima ou nenhuma relação direta têm com o livro (BELLO, 1977 [1ª. ed. 1945], p. 91).

Para ilustrar essas possíveis “falhas” nos romances queirosianos, Bello elenca os cinco romances publicados quando Eça ainda estava vivo, excluindo A Correspondência de Fradique Mendes e as crônicas jornalísticas que são analisadas em outra categoria mais adiante. Por conseguinte, o quadro construído pelo brasileiro fica da seguinte forma:

\begin{tabular}{|c|c|c|}
\hline \multicolumn{3}{|c|}{ LIVROS DA FASE REALISTA } \\
\hline ROMANCES & VIRTUDES & DEFEITOS \\
\hline O Crime do Padre Amaro & $\begin{array}{l}\text { - qualidades básicas de } \\
\text { observação; } \\
\text { - inspiração fresca; } \\
\text { - apesar de "material } \\
\text { humano de terceira ou } \\
\text { quarta ordem” (p. 79) } \\
\text { fez um livro admirável; } \\
\text { - livro de orgulho; } \\
\text { - nenhuma dissonância; } \\
\text { - a arquitetura obedece } \\
\text { ao melhor modelo } \\
\text { realista; } \\
\text { - o estilo; } \\
\text { - força evocativa. }\end{array}$ & $\begin{array}{l}\text { - tema banal (o celibato); } \\
\text { - personagens medíocres } \\
\text { (faltava-lhes vida interior, } \\
\text { vontade, relevo e atitude); } \\
\text { - ação pouco dramática; } \\
\text { - não tem singeleza e graça } \\
\text { perfeita; } \\
\text { - excessos de minúcias } \\
\text { inúteis; } \\
\text { - exagero caricatural dos } \\
\text { traços; } \\
\text { - frases e imagens de mau } \\
\text { gosto. }\end{array}$ \\
\hline O Primo Basílio & $\begin{array}{l}\text { - descrição da cidade; } \\
\text { - estilo mais condensado; } \\
\text { - frase mais mordente; } \\
\text { - ironia mais acirrada. }\end{array}$ & $\begin{array}{l}\text { - desvio da escola literária } \\
\text { realista; } \\
\text { - a personagem Luísa é } \\
\text { medíocre; } \\
\text { - faltam as paisagens rurais; } \\
\text { - não é notável a faculdade } \\
\text { criadora; } \\
\text { - situações grotescas; } \\
\text { - palavras de espírito; } \\
\text { - detalhes infelizes. }\end{array}$ \\
\hline Os Maias & $\begin{array}{l}\text { - Afonso da Maia como um } \\
\text { símbolo de perfeita } \\
\text { nobreza; } \\
\text { - o livro de maior êxito; } \\
\text { - uma alegre mascarada da } \\
\text { sociedade lisboeta; } \\
\text { - livre das rígidas normas } \\
\text { do romance típico; }\end{array}$ & $\begin{array}{l}\text { - sem unidade fundamental; } \\
\text { - ausência de fortes } \\
\text { paixões; } \\
\text { - personagens moralmente } \\
\text { primárias; } \\
\text { - material de segunda mão; } \\
\text { - situações e cenas } \\
\text { repetidas dos livros }\end{array}$ \\
\hline
\end{tabular}




\begin{tabular}{|c|c|c|}
\hline & $\begin{array}{l}\text { - exalta-lhe a veia cômica; } \\
\text { - frases bem elaboradas; } \\
\text { - sátira dos costumes } \\
\text { lisboetas; } \\
\text { - o livro que esclarece } \\
\text { melhor as ideias, os } \\
\text { sentimentos, as aspirações } \\
\text { e a revolta de Eça. }\end{array}$ & $\begin{array}{l}\text { anteriores; } \\
\text { - os mesmos efeitos } \\
\text { cômicos (o mínimo de } \\
\text { originalidade); } \\
\text { - exageros caricaturais; } \\
\text { - mau gosto romântico; } \\
\text { - cenas falsas e } \\
\text { convencionais; } \\
\text { - defeitos de composição. }\end{array}$ \\
\hline O Mandarim & $\begin{array}{l}\text { - vivacidade e graça do } \\
\text { estilo. }\end{array}$ & $\begin{array}{l}\text { - espécie de apólogo sobre } \\
\text { tema já explorado; } \\
\text { - fantasiar um lugar (China) } \\
\text { que nunca conheceu; } \\
\text { - personagens mal } \\
\text { esbatidos; } \\
\text { - não pode ser tratado como } \\
\text { romance. }\end{array}$ \\
\hline A Relíquia & $\begin{array}{l}\text { - tem consistência; } \\
\text { - crítica alegre às } \\
\text { deformações da vida beata; } \\
\text { - romance dentro de outro } \\
\text { romance; } \\
\text { - personagens típicos da } \\
\text { galeria eciana; } \\
\text { - revela, talvez, os } \\
\text { possíveis conflitos } \\
\text { interiores das dúvidas } \\
\text { religiosas do autor; } \\
\text { - poder evocativo do estilo } \\
\text { de Eça; } \\
\text { - prosa viva e colorida. }\end{array}$ & $\begin{array}{l}\text { - difícil classificação entre } \\
\text { os gêneros; } \\
\text { - trama sem originalidade; } \\
\text { - sonho do Raposão com o } \\
\text { canalha que o sonhou. }\end{array}$ \\
\hline
\end{tabular}

Nessa galeria de adjetivos elencados por Bello para estabelecer uma linha divisória entre o que é considerado por ele como virtudes e defeitos na obra do autor português, verifica-se que ele acompanha a crítica machadiana quando faz referência ao Crime e ao Primo, porém, apresenta-se extremamente categórico, para não dizer ofensivo, ao realçar a falta de originalidade de Eça, acusando-o de utilizar "resíduos de leitura”, ou pior ainda, o crítico afirma que "qualquer catador atento de pulgas em elefante descobriria sem grandes esforços os seus possíveis modelos ou, pelo menos, as fontes alheias que os teriam sugerido” (BELLO, 1977 [1ª. ed. 1945], p. 91-92). Contudo, em seguida, ameniza seu 
ponto de vista ao destacar que o mérito de Eça estava no seu poder de inovar o que já existia.

Com relação aos três romances realistas de publicação póstuma A Capital, O Conde de Abranhos e Alves \& Cia., Bello declara que “em nada lhe [Eça] aumentaram a glória de escritor” (BELLO, 1977 [1ª. ed. 1945], p. 92) e acrescenta que se Eça estivesse vivo, não teria permitido a publicação desses textos sem uma revisão mais detida. Bello imagina que se tivesse sido o próprio autor que tivesse concluído esses textos, eles apresentariam um pouco mais de análise e, seguindo a mesma linha divisória entre virtudes e defeitos, ele faz outra lista.

\begin{tabular}{|c|c|c|}
\hline \multicolumn{3}{|c|}{ LIVROS DE PUBLICAÇÃO PÓSTUMA } \\
\hline ROMANCES & VIRTUDES & DEFEITOS \\
\hline A Capital & $\begin{array}{l}\text { - flagrante do mundo } \\
\text { literário e jornalístico de } \\
\text { Lisboa. }\end{array}$ & $\begin{array}{l}\text { - tese batida; } \\
\text { - tema de antigo sabor } \\
\text { romântico; } \\
\text { - romance monótono; } \\
\text { - páginas forçosamente } \\
\text { escritas. }\end{array}$ \\
\hline O Conde de Abranhos & $\begin{array}{l}\text { - personagens } r \\
\text { preenchem aue } \\
\text { eciana; } \\
\text { - retrato do cenário de } \\
\text { Lisboa. }\end{array}$ & $\begin{array}{l}\text { - romance monótono; } \\
\text { - estilo incerto; } \\
\text { - panfleto de um } \\
\text { apaixonado; } \\
\text { - criação artificial e fria; } \\
\text { - motivo pessoal } \\
\text { (vingança); } \\
\text { - não tem enredo; } \\
\text { - caricatural. }\end{array}$ \\
\hline Alves \& Cia. & $\begin{array}{l}\text { - menos defeituoso que os } \\
\text { outros romances } \\
\text { publicados após a morte de } \\
\text { Eça. }\end{array}$ & $\begin{array}{l}\text { - romance pobre; } \\
\text { - tom agressivo e } \\
\text { panfletário; } \\
\text { - ausência de caracteres; } \\
\text { - abuso de minúcia ou } \\
\text { digressões. }\end{array}$ \\
\hline
\end{tabular}


Nesse breve resumo que Bello faz desses três romances póstumos, verifica-se que ele levanta mais defeitos que virtudes visto que para o crítico eles representam o que havia de pior na escola literária realista.

E dando continuidade a sua lista de problemas detectados na obra de Eça, afirma que o autor tinha uma "deficiência inventiva” que levara por toda carreira alcançando os últimos romances do realista português.

Desguarnecida do vistoso mobiliário da mocidade, a sua inteligência como que se renova e se retempera. Todavia, como foi sempre pouco especulativo, não se lhe voltou o pensamento, na idade madura, à semelhança do que tantas vezes se verifica entre homens de alta inteligência, para os graves problemas do conhecimento ou do que é universal e eterno. Contentou-se com um suave retorno às coisas simples e puras da vida e com um patriotismo sentimental e bucólico, um nacionalismo de paisagem, que o seu habitual tom de alegre ironia impede de incidir no pieguismo romântico por ele mesmo tantas vezes cruelmente satirizado... (BELLO, 1977 [1ª. ed. 1945], p. 101).

Nesse trecho, nota-se que Bello segue o caminho dos primeiros queirosianos brasileiros e retrata um Eça - a partir dos últimos romances - patriota, bucólico, fazendo as pazes com Portugal. O crítico não consegue mais ver nesses textos da "Segunda Fase” o escritor polêmico e revolucionário da "Fase Realista”. Observa-se que Bello reconhece até uma leve postura romântica por parte de Eça na escrita de suas últimas produções.

Percorrendo os últimos textos da obra queirosiana, o crítico destaca dois romances, A Ilustre Casa de Ramires e A Cidade e as Serras; a hagiografia; as vidas de santos; A Correspondência de Fradique Mendes, completando o retrato sobre a produção artística de Eça.

Sobre os romances, Bello alega que Eça estaria desiludido com o Realismo e procurava novos motivos para escrever. 
O mundo, mesmo, o pobre mundo do "constitucionalismo português" da sua época, não se enchia apenas dos padres devassos e das beatas idiotas de Leiria, das burguesas adúlteras, dos políticos, dos jornalistas canalhas, dos esnobes e dos literatos fracassados de Lisboa. Havia ainda muita gente decente a ser contada e, sobretudo, muita paisagem campestre a ser descrita. Os seus tipos tornam-se mais humanos, no sentido universal, ainda que menos definidos na ação, do que no período realista, e sempre, psicologicamente, não muito complexos (BELLO, 1977 [1ª. ed. 1945], p. 103).

Bello compreende que o autor sentia necessidade também de mostrar o lado positivo de Portugal, mesmo que, para isso, tivesse que tomar um posicionamento romântico.

Nos dois romances da "Segunda Fase”, observa uma riqueza no uso da língua portuguesa como instrumento de expressão, mas salienta a falta de cuidado de Eça perante a gramática. Levanta aspectos de um escritor desatento, que deixava passar vários erros em seus textos. Em consonância com isso, Bello afirma que a vida dos santos representa “a descida da montanha do talento literário de Eça de Queirós” (BELLO, 1977 [1ª . ed. 1945], p. 111). Apontaria para essa decadência artística três fatores: a falta de imaginação, a falta de interesse pelos romances de combate e a falta de inspiração pelos romances bucólicos.

Salva-lhe apenas alguns dos esboços de seus últimos projetos.

Infelizmente, a literatura infantil, que condiria tão bem com o seu amor pelas crianças e a graça fácil das suas narrações, ficou apenas em vago projeto. Da hagiologia pôde, no entanto, deixar-nos as vidas de São Cristóvão, de Santo Onofre e, inacabada, a de São Frei Gil, sem incluir o pequeno conto sobre Frei Genebro (BELLO, 1977 [1 ${ }^{\text {a. }}$ ed. 1945], p. 111).

Bello também não poupa as crônicas para a imprensa portuguesa e brasileira (Cartas da Inglaterra, Ecos de Paris, Cartas Familiares e Crônicas de Londres), reafirmando que em nada as crônicas aumentariam a glória literária de Eça, porque o escritor português nunca fora "um rapaz observador dos fenômenos políticos e sociais" 
(BELLO, 1977 [1 $1^{\text {a }}$ ed. 1945], p. 116), principalmente quando escrevia sobre política internacional.

De toda a obra de Eça, destaca alguns ensaios biográficos como sendo a representação do talento literário do escritor, pois fora ali que Eça conseguira transmitir sua genialidade. Além disso, o crítico também ressaltou alguns ensaios em Notas Contemporâneas, na qual Eça revisita as suas próprias ideias e estética, além de comentar sobre as correspondências, que foram leituras prazerosas, de onde surgira o "homem fino e bondoso, do amigo terno e solícito” (BELLO, 1977 [1ª ed. 1945], p. 128).

Ao destacar o estilo de Eça, Bello também aponta o pensamento por detrás desse estilo como aspecto primordial da obra do escritor, isto é, há uma aproximação entre "forma” e "fundo". O crítico observa que o autor, ao transmitir o pensamento por meio de seu estilo, encontrara a si próprio e começara “a construir a sua casa 'pessoal"” (BELLO, 1977 [1 $1^{\text {a }}$ ed. 1945], p. 135). Desse modo, Bello compreende que Eça transitara pelas incertezas no início da carreira e a firmeza no final uma vez que, no começo da carreira, Eça ainda estava submerso e oscilante perante tantas influências, e o seu estilo fora lapidado por forças internas e externas a ele, visto que

o escritor não escolhe arbitrariamente o estilo que deseja, mas, sim, o que lhe corresponda às suas determinantes fisiológicas e psicológicas, apuradas pela educação literária, pelo constante esforço, em suma, por “circunstâncias extrínsecas” (BELLO, 1977 [1ª. ed. 1945], p. 42).

Para o estudioso, é somente através do tempo que o estilo de Eça fora se aprimorando e as palavras passaram a obedecer ao seu mestre: "Com os seus olhos de 'pintor' Eça soube 'ver' excelentemente e, muitas vezes, fixar o que viu. Multiplicam-se por todos os seus livros os grandes e pequenos quadros de todo gênero, que nunca mais esquecemos” (BELLO, 1977 [1ª ed. 1945], p. 141). 
Sobre a ironia, Bello afirma que ela estava presente "sobre todas as virtudes de fundo e de forma” (BELLO, 1977 [1ª . ed. 1945], p. 148) sendo responsável por dar sentido à obra de Eça. E é desse modo que Bello trilha a sua análise sempre na tentativa de apontar os altos e baixos na produção escrita de Eça.

No seu breve estudo monográfico, Stênio Lopes retoma as velhas discussões em torno da biografia, dando destaque ao que ele considera de "fase trágica" de Eça: a infância. Ele nota que a predisposição do escritor para produzir literatura pelo viés do imaginário tem como fonte as histórias do avô e do velho escravo, ambos com experiências brasileiras.

\begin{abstract}
A formação mental de Eça de Queirós iniludivelmente principia nesta quadra. A figura de seu avô, revolucionário e liberal numa época em que Portugal, fechado em sua rudimentar economia agrícola, "o peso secular do santo ofício travando o avanço das ideias de europeização", se arrastava lentamente dentro da tradição e do conservadorismo, quando do outro lado dos Pirineus a Revolução tinha varrido a França e toda a Europa caminhava febrilmente para novos destinos - a figura de seu avô - dizia - avultava no espírito curioso do menino de 10 anos que, não conhecendo o pai, voltava para o ancião todo o ardor primitivo de seu afeto e de sua admiração (LOPES, 1945, p. 13).
\end{abstract}

Nessa perspectiva analítica que aproxima biografismo e psicologia, Lopes mantém diálogo direto com os textos fundadores, em especial, com Viana Moog, quando ambos compartilham a hipótese de Eça ter produzido uma obra autobiográfica: “É que esse magnífico autor autobiográfico reparte, com os principais personagens de sua obra, um pouco de si mesmo, uma ou outra faceta de seu espírito multiforme, de sua complexidade religiosa” (LOPES, 1945, p. 19). Outro estudioso, José de Melo Jorge, da crítica seminal, também pode ser considerado fonte de informações para Stênio Lopes nesse aspecto, principalmente, na pesquisa que Melo Jorge empreendeu sobre a construção dos personagens queirosianos. 
Apesar de Stênio Lopes reproduzir todo o percurso biográfico e histórico-literário dos demais, ele apresenta um diferencial, que já aparecia em Clóvis Ramalhete, no que tange à homogeneidade da obra de Eça. Assim, para ele, a produção do escritor é “fiel a si mesma” (LOPES, 1946, p. 23).

No texto de Stênio Lopes, um elemento que pode ser considerado inovador é o fato de o brasileiro não citar o termo "influência” para comentar as leituras que Eça fazia de outros escritores e pensadores, mas ressalta que o autor português passara por um processo de “aprendizagem” à respeito da experiência que tivera com diferentes textos. Tem-se aqui uma visão menos reducionista concernente à obra queirosiana, já que esse processo de aprendizagem é tomado por Lopes como aspecto positivo na construção dos elementos narrativos, mesmo em Os Maias, tão criticada pelo retrato considerado distorcido da realidade portuguesa. Desse modo, ele afirma que

aqui justamente reside o fato de os personagens de Eça de Queirós terem ultrapassado as fronteiras de Portugal. É que, sem deixarem de ser bem portugueses, eles são tipicamente humanos, (maneira de ser); encontramse em todos os países e sob todas as latitudes; são universais. Nisto, sobretudo, está a razão por que os Brasileiros lêem Eça com tanto agrado, porque ele permanece para nós o mais conhecido e o mais amado dos escritores portugueses de todos os tempos. E muitos outros povos o leriam na mesma forma, se a língua portuguesa fosse mais conhecida e generalizada no mundo. Porque Eça de Queirós é um dos maiores escritores de seu século, devendo-se buscar nas literaturas mais avançadas da Europa os estalões para comparação de sua obra (LOPES, 1945, p. 58).

Contudo, mesmo na tentativa de criar uma leitura nova sobre Eça, Stênio Lopes não foge da análise biográfica, construindo a mesma imagem do escritor como artista talentoso, sem valorizar o aspecto de sua obra.

Todos esses estudos estão interligados pela análise que desenvolveram da vida de Eça para compreender a obra e, em nada, modificaram a imagem do escritor português promovida pela crítica seminal. 


\section{A leitura de Eça pela perspectiva psicológica}

A abordagem psicológica da obra queirosiana ganha força com o estudo intitulado Eça, literária, psicoanaliticamente (1948), de Constantino Paleólogo (1922-).

Essa perspectiva crítica consiste em explicitar a literatura por meio de um determinado universo onírico por meio de acontecimentos da infância do escritor. No caso específico desse estudo, ele propõe verificar como o subconsciente teve papel considerável na criação artística. Embora trate da vida do autor, o que fariam dele somente uma biografia, o crítico brasileiro optou por procurar nas obras os motivos recorrentes que poderiam determinar quem é o artista psicologicamente tomado. Desse modo, o que ele produziu é o que a psicologia chamaria de psicobiografia, termo presente nos estudos dos analistas do início do século XX.

Constantino Paleólogo até tentou não retomar a abordagem biográfico-psicológica da maneira como fizeram os primeiros queirosianos para desenvolver um estudo analíticointerpretativo da obra de Eça por meio da observação das “intrigas” dos romances. No entanto, o que surge nas linhas do crítico brasileiro é a visão tradicional enraizada pela crítica seminal: “O romance é, no caso de Eça de Queirós e de muitos outros, uma compensação da vida. O criador faz com que seus personagens façam o que ele, por motivos diversos, não pôde, não ousou fazer ou talvez nunca pensasse conscientemente em fazer” (PALEÓLOGO, 1948, p. 21). O crítico determina quatro classificações para se entender a obra de Eça: a primeira, obras evocativas, são aquelas inseridas na primeira fase de produção literária do escritor e que estão centradas nas descrições da vida familiar, da vida escolar e da vida amorosa, ou seja, são obras de alto teor emocional e afetivo, mas que, segundo o crítico, não revelam o grande escritor; a segunda, obras imitativas, são aquelas em que Eça recebera a "influência” de seus autores preferidos; a terceira, obras de 
criação dirigida, são aquelas sem um fundo psicológico, mais voltadas à verdadeira manifestação artística distribuídas pelas crônicas, ensaios, críticas; e a quarta, obras de criação espontânea são aquelas oriundas supostamente do subconsciente do autor.

Na análise psicológica que Constantino Paleólogo empreende, justifica-se a escolha de Eça pelo Realismo-Naturalismo, pois tais vertentes estéticas conseguiriam dar suporte para que o autor expressasse os seus fenômenos psíquicos de maneira livre, sem as amarras do Romantismo. Retoma-se da crítica seminal a ideia de que Eça precisava desabafar na escrita as angústias da infância.

Esse triste início de vida pode ser facilmente reconstituído. Depois de viver cerca de quatro anos em casa de gente desconhecida, de condição modesta, Eça vai morar em casa da avó e depois na dos pais. Ora, na casa do alfaiate e da costureira era um estranho, filho de outros. Diante dos amigos eles certamente murmurariam: "é filho natural de fulano e de sicrana”. E perguntariam de quando em vez: "então, os pais dele quando é que se casam?” O menino ouviria tais palavras, que se gravariam de modo indelével em seu coração frágil e delicado, trazendo-lhe os primeiros sofrimentos. Já na casa da avó teria sido recebido secamente, com altivez, porque, pobre dele, era um fruto do pecado. Na casa dos pais, em seguida, sua posição deveria ser demasiado esquerda. "Como? Casados há tão pouco tempo já tinha um filho daquele tamanho?” Podemos imaginar o pequeno José Maria escondido quando chegava alguma visita de cerimônia a fim de evitar perguntas indiscretas e embaraçosas. Porque, após o casamento, a família tornou-se respeitável, séria e somente havia uma criaturinha que com a sua simples presença, destruía irremediavelmente toda aquela aparência de circunspeção: o magro José Maria (PALEÓLOGO, 1948, p. 45-46).

Realizando o percurso pelas possíveis perguntas realizadas pela família ou por outras pessoas durante a infância de Eça, Paleólogo argumenta que, nos textos de criação espontânea, são revelados, com base nas experiências negativas de Eça de seus primeiros anos, "satisfação do impulso incestuoso; representação diminuidora da personalidade paterna; caracterização da falsidade dos sentimentos da avó; glorificação do avô" (PALEÓLOGO, 1948, p. 48). 
Destaca-se, na crítica de Paleólogo, a sua imaginação, isto é, como ele "reinventa” o passado de Eça, colocando-se na posição do escritor como se ele estivesse lá, vivenciando os seus momentos íntimos. A sensação que se tem, ao ler a análise do crítico brasileiro, é a mesma de quando se lê um roteiro: as falas e as personagens estão prontas, construídas como o roteirista e o diretor desejam. O que se quer dizer com isso? Que, forçosamente, Paleólogo tem por objetivo persuadir seu leitor de que a obra de Eça foi embasada na sua infância triste. Contudo, nada o comprova: talvez tenha acontecido como ele descreve, talvez não - é o máximo de conclusão a que se pode chegar.

Dando continuidade a essa perspectiva, Paleólogo determina a ida de Eça à Coimbra como uma "fuga psicológica” confirmando a opinião dos textos fundadores, que prosseguiria na viagem ao Oriente, e dela, como afirma Paleólogo: “Eça de Queirós voltou outro homem [...]” (PALEÓLOGO, 1948, p. 51). Esses dois momentos de fugas apontados pelo crítico brasileiro foram colocados na posição de responsáveis pelo fim da "censura” na personalidade de Eça, que fora construída com base em ensinamentos morais, religiosos e sociais.

Coimbra foi um poderoso agente demolidor da censura do romancista que, ouvindo as ideias arrojadas dos que então pontificavam, começou a empurrar para um plano secundário as noções morais que havia adquirido na infância. Inconscientemente suspeitou que, aderindo às idéias dominantes, encontraria um caminho seguro para a libertação de seus recalques. Foi, aos poucos, vencendo a timidez que o tolhia e dentro em breve entrou a tomar parte ativa nos acalorados debates em que se discutia a existência de Deus e se vituperava a estupidez e o fingimento dos burgueses (PALEÓLOGO, 1948, p. 53-54).

Verifica-se, na análise de Paleólogo, uma linha freudiana, uma vez que, para ele, o processo de construção literária de Eça advinha do subconsciente, que representava o impulso sexual do escritor. Assim, partindo desse princípio, é possível observar que o brasileiro estabelece a seguinte relação: “Amaro é ele próprio, o cônego é seu pai, a S. 
Joaneira sua mãe e Amélia a irmã” (PALEÓLOGO, 1948, p. 64). Tudo isso para provar que Eça, molestado pelo “problema angustiante do sexo” (PALEÓLOGO, 1948, p. 67), servira-se da figura de um padre para controlar o seu impulso incestuoso, isto é, para Paleólogo a escolha do personagem principal do Crime ter sido um padre representara o desejo de Eça de se ver “forçado a conservar a castidade” (PALEÓLOGO, 1948, p. 68). Na verdade, o que o crítico brasileiro defende é que Eça tivera como objetivo principal: representar o "erro" dos seus próprios pais. Os mesmos encontros proibidos entre Amaro e Amélia, o Cônego e S. Joaneiro, serviram como forma de representação do encontro com José Maria e Carolina e, deste ato amoroso, a concepção do fruto proibido.

Ao comentar sobre $O$ Primo Basílio, Paleólogo afirma que o segundo romance fora resultado de uma progressão e "feita a experiência inicial, o romancista se afoita a representar com mais verdade o problema do subconsciente” (PALEÓLOGO, 1948, p. 93). Para ele, os romances o Crime e o Primo foram escritos com fins morais e educativos e que Eça utilizaria da imoralidade para passar a moral à sociedade portuguesa, ou seja, "o consciente de Eça, convicto de que trabalha pela moralização da sociedade portuguesa, não se perturba ao tratar dos mais escabrosos assuntos [...]” (PALEÓLOGO, 1948, p. 96).

Se no Primo Eça recorrera a imagens fortemente eróticas nos encontros entre Basílio e Luísa, isso se justifica, segundo Paleólogo, ao próprio temperamento do escritor. Em vista disso, o crítico brasileiro abrange toda a produção literária de Eça regida por um único motivo: “a necessidade de satisfazer os seus impulsos inconscientes” (PALEÓLOGO, 1948, p. 97).

Mais adiante, o crítico retoma a ideia de O Primo também ser a representação de desejos sexuais destituídos de uma base moral, por isso volta a fazer relações afirmando que a personalidade de Eça estava fragmentada no romance: "Basílio, o impulso 
incestuoso; Sebastião e Jorge, duas metades do irmão que protege; Juliana, a censura corrompida” (PALEÓLOGO, 1948, p. 108).

Para o crítico, o romance Os Maias fora um divisor de águas. Antes, Eça apresentava um comportamento explosivo e, depois, um comportamento passivo. Pensando nisso, Paleólogo nota que o escritor português, a partir de Os Maias, conseguira resolver seu problema psíquico “e a sua consequente libertação das cadeias sensuais que lhe deformavam a visão dos homens e das coisa”" (PALEÓLOGO, 1948, p. 125).

Paleólogo, muito mais do que nos Maias, verifica que fora em A Cidade e as Serras que Eça encontrara paz e se reconciliara com Portugal e com a família, abrindo caminho para escrever as lendas dos santos.

Logo, verifica-se que, na concepção de Constantino Paleólogo, a obra de Eça é fragmentada, porém, não como os outros queirosianos a colocaram, embasada nas mudanças comportamentais, e sim determinada pela psicologia do autor: "partindo da violação chegou ao incesto, sempre num crescendo de sensualidade e, depois de liberto, seguiu num crescendo de espiritualização, até alcançar o Cristo por intermédio das Lendas dos Santos” (PALEÓLOGO, 1948, p. 201).

Em suma, Paleólogo remonta a evolução psíquica de Eça afirmando que as críticas realizadas pelo escritor à religião, à família, à sociedade portuguesa causaram-lhe “satisfação intrapsíquica de seus impulsos” (PALEÓLOGO, 1948, p. 229). Assim, o estudo psicanalítico realizado por Paleólogo sobre Eça destaca o complexo de Édipo instaurado na obra do escritor, determinante na construção dos personagens queirosianos.

Diante do exposto, parece que há um leve movimento em direção a uma nova crítica sobre Eça, todavia, o que existe é um aprofundamento da abordagem psicológica em Paleólogo, que já havia sido trabalhada pela crítica seminal de maneira menos pontual. 
Observou-se, neste capítulo, a herança da crítica seminal em outros estudos queirosianos, que mantiveram as perspectivas críticas adotadas pelos textos fundadores. Tanto os ensaios do Livro do Centenário quanto os volumes, retomaram as ideias dos primeiros estudos e se aprofundaram nelas com o objetivo de dar segurança às análises, retirando o aspecto duvidoso que, às vezes, aparecia na crítica seminal.

A seguir, serão apresentados textos que romperam com esse modelo de crítica iniciada no século XX, trazendo novas abordagens e concepções sobre Eça de Queirós. 


\section{CAPÍTULO III}

\section{ALGUNS NOVOS OLHARES A RESPEITO DE EÇA NO BRASIL}

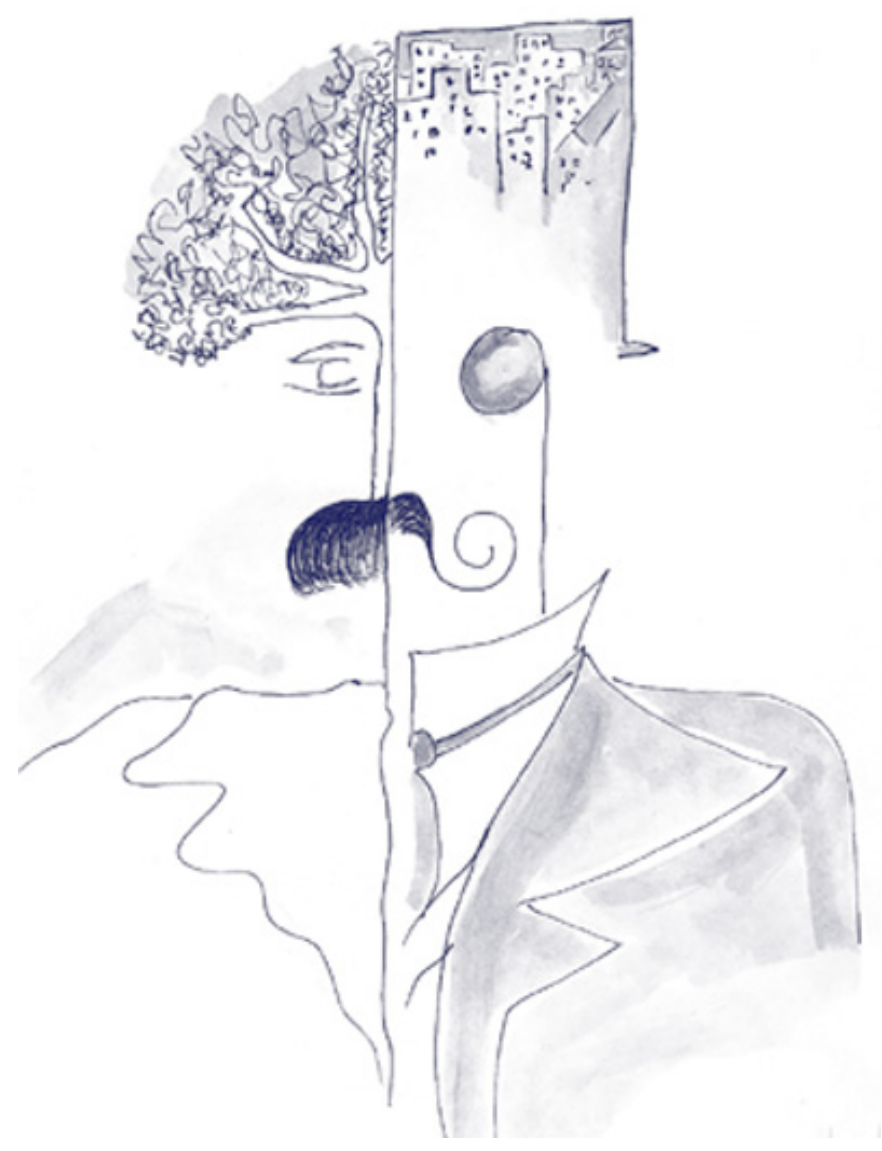




\section{A ruptura da crítica seminal sobre Eça de Queirós no Brasil}

Este último capítulo apresenta as leituras brasileiras sobre Eça que romperam as limitações de análise da crítica seminal, surgindo novas respostas críticas sobre a obra queirosiana entre as duas efemérides (1945-2000).

Observa-se que, em alguns estudos desse período, houve o distanciamento do biografismo e do psicologismo na interpretação da produção escrita do autor português, nascendo novas perspectivas críticas que passaram a analisar Eça não mais por meio da imagem do artista talentoso, mas, sobretudo, recuperando a imagem intelectual do escritor ao se aprofundarem em outras facetas de Eça como político e jornalista.

A leitura de Eça que se apresenta, neste instante, está vinculada à construção da imagem do autor por intermédio de reflexões que privilegiaram a relação dele com a realidade de sua época e a competência de sua produção escrita. Além disso, despontaram, no Brasil, diversos estudos que trataram a recepção de Eça no país, destacando a aproximação do público brasileiro com a vida e a obra do autor.

\section{A tensão dialética na obra queirosiana}

Em 1945, o jovem crítico Antonio Candido (1918-), publicou um importante ensaio no Livro do Centenário intitulado “Eça de Queiroz entre o campo e a cidade”, que, mesmo ligado historicamente à crítica seminal, traz uma nova reflexão quando apresenta uma análise dialética da obra queirosiana mostrando os conflitos urbanos e rurais que são construídos no decorrer da produção do escritor.

Candido mostra que, quando a perspectiva de um romance é a da cidade, o texto apresenta um aspecto revolucionário em função dos aspectos peculiares das cidades como 
velocidade e progresso; e, quando a perspectiva de um romance é a do campo, o ritmo do texto é outro, tomado pelos aspectos da vida rural que a natureza proporciona como tranquilidade e momentos de reflexão.

Para o estudioso, a ficção urbanista estaria representada nos primeiros romances, com O Crime do Padre Amaro e $O$ Primo Basílio, tendo sua expansão maior em $A$ Correspondência de Fradique Mendes que é uma

espécie de tratado do homem moderno, que marca o apogeu do urbanismo de Eça. O personagem ideal de Fradique é o homem supercivilizado do século XIX, flor das grandes cidades, que absorve todos os requintes e comodidades da civilização (CANDIDO, 1945, p. 142-143).

Na transição entre o urbano e o rural, Antonio Candido coloca Os Maias como o romance de transformação e de retrato da tensão do homem entre o espaço urbano e rural. Para o brasileiro, é nessa publicação que Eça conseguira equilibrar as duas perspectivas, o que faz Candido afirmar que é o romance mais elaborado do autor.

Eça já não era mais o romancista urbanófilo das primeiras obras, como não era mais, também, o socialista dos primeiros tempos. Já havia abandonado a linha da oposição e do sarcasmo integral. O colaborador d'As Farpas, para quem a salvação do país estava na introdução do progresso técnico e científico e na liquidação do paternalismo agrário, começara a deixar-se invadir pela sedução do velho Portugal. Os seus romances irão revelando, pouco a pouco, um abandono do ponto de vista urbanista em proveito do sentimento rural, em proveito daquele mesmo passado que ele a princípio renegou integralmente. Os Maias exprimem com nitidez este recuo ou, se quiserem, progresso (CANDIDO, 1945, p. 144-145).

Antonio Candido afirma que a perspectiva do campo em A Ilustre Casa de Ramires e A cidade e as Serras aparece naturalmente uma vez que, no século XIX, seria impossível a construção de um “perfeito romance urbano” (CANDIDO, 1945, p. 149), porque naquela época a "Civilização ainda [estava] solidamente enraizada no campo, de onde [recebia] 
seiva, energia, embora tomando em relação a ele posições as mais das vezes antagônicas” (CANDIDO, 1945, p. 149). À vista disso, observa-se que Candido nega a leitura de outros estudiosos que acreditavam que Eça tinha se reconciliado com a pátria, pois para ele a presença do ruralismo, em seus últimos livros, era uma “opção de ordem estética e não política” (CANDIDO, 1945, p. 154), isto é, ele acredita que Eça não mudara suas convicções políticas e revolucionárias dos primeiros para os últimos livros.

Assim, tomando a produção de Eça pela dialética entre cidade e campo, Candido se afasta da crítica seminal em dois momentos: o primeiro, quando defende o caráter unificador da obra queirosiana; e o segundo, quando ressalta o lado político e intelectual de Eça. Ambos os momentos inauguraram, na primeira metade do século XX, uma imagem do escritor, até então, pouco trabalhada na época: do autor de espírito combativo.

\section{A interpretação estilística da obra queirosiana}

Também no Livro Centenário surge um novo olhar sobre Eça no ensaio intitulado “Linguagem e estilo de Eça de Queiroz”, de Aurélio Buarque de Holanda, que analisa a obra queirosiana pela perspectiva da estilística.

A abordagem tomada pelo brasileiro é contrária à visão da crítica seminal que analisou, em geral, a obra de Eça por meio de elementos extraliterários. Para Buarque de Holanda, o que importava era a autonomia do fenômeno literário, centrada em uma análise da obra em si mesma e de seus elementos intrínsecos.

Dessa forma, ele se centra na expressividade das formas linguísticas, objetivando verificar o que Eça trouxera internamente a sua forma de criar literatura. Desse modo, o que o ensaísta faz é registrar o estilo único do escritor português por meio do levantamento dos traços característicos da sua obra, sempre com a preocupação de observar não o que Eça escrevera, mas a maneira como ele o fizera. 
Para a grande parte da crítica queirosiana brasileira, a forma como Eça escrevera passara a ser conhecida como inovadora. A crítica seminal concebeu essa inovação da linguagem queirosiana uma postura necessária para descrever a realidade da época, contudo, para Aurélio Buarque de Holanda era o destino de Eça “exercer a grande renovação" (HOLANDA, 1945, p. 60). A função do escritor seria a “de aproximar do século, do seu meio social, dos seres de carne e osso, o idioma que andara tão longamente a serviço dos clássicos, a exprimir a fé religiosa, a pintar figuras e emoções de um mundo mitológico, a restaurar costumes e ideais da Idade Média” (HOLLANDA, 1945, p. 61), aproximando-o, assim, da realidade do século XIX.

O terreno da estilística é vasto e abrange os limites da gramática, fornecendo a esta subsídios valiosos. Buarque de Holanda passa por três níveis de análise estilística: a fônica, a morfológica e a sintática.

No primeiro nível, fônica, há, para ele, na obra de Eça, dois aspectos que trabalham a percepção auditiva: o primeiro, que denomina como “vícios e virtudes estilísticas”; o segundo, que denomina "notas soltas". No primeiro aspecto, o brasileiro analisa o uso intencional ou não de parequemas, cacofonias, hiatos, aliterações viciosas e ecos, chegando à conclusão de que Eça “soube de alguns desses vícios fazer virtudes” (HOLANDA, 1945, p. 96). Assim, o que faz o brasileiro é levantar alguns exemplos desses “vícios” na obra queirosiana para comprovar que o poder da harmonia imitativa de sua escrita é elemento importante para interpretar as ideias do autor. No segundo aspecto, o ensaísta destaca o uso das vogais, o diálogo, a dramaticidade, a originalidade nas frases repetidas e o instinto poético na disposição das palavras como elementos essenciais na construção escrita do autor português. Desse modo, o ensaísta observa uma intensa musicalidade na obra queirosiana, que leva o leitor a transitar em diferentes atmosferas: de sonho, de misticismo, de realidade, aguçando o sentido da audição daquele que lê os textos de Eça. 
No segundo nível, morfológica, o objeto de estudo de Buarque de Holanda é o uso expressivo das formas gramaticais, dos adjetivos, dos substantivos, do estrangeirismo e do vocabulário. Para ele, são elementos importantes no projeto de inovação da linguagem criado por Eça. Embora o brasileiro comente a crítica advinda dos puristas, realça esses cinco elementos como os grandes valores da produção artística do autor pelo fato de serem instrumentalizados por meio do que Eça queria: o ritmo. Sobre isso, Aurélio Buarque de Holanda nota que a escrita de Eça é embasada na sua intensa percepção sensorial sobre os aspectos humanos e das coisas, por isso a necessidade de inovar a linguagem na busca de acrescentar à escrita sua personalidade.

No terceiro nível, sintática, o objeto de estudo é a construção da frase, que aparece na análise dele por meio de dois elementos: o solecismo e o uso da ordem direta e inversa. A respeito do primeiro, o brasileiro nota que Eça mudara a regência da gramática normativa, que o levara a receber muitas críticas, que foram abandonadas por Buarque de Holanda, que passa a defender os usos inovadores da regência em Eça, buscando, em outros escritores, apoio para sua defesa à escrita do autor realista. Sobre o segundo, o ensaísta aponta para o uso da ordem direta do português para enfatizar, muitas vezes, o efeito da rotina, da simplicidade, da segurança, que ele queria transmitir, porém o brasileiro ressalta o uso da inversão nos textos de Eça com o objetivo de chamar a atenção o leitor para aquela ação inusitada dos personagens.

Percorrendo os três níveis de análise estilística empreendidos por Aurélio Buarque de Holanda, verifica-se que ele interpreta a linguagem e o estilo de Eça como um reflexo cultural, levando em consideração o aparato afetivo e emocional que caracterizara a expressividade do autor. Assim, o que o brasileiro deixa para a posteridade é uma crítica fundamentada no princípio do respeito à criação e à criatura, despreocupada em descobrir “defeitos” na obra literária queirosiana, mas sim, em compreender o estilo de Eça e sua 
eficácia. É uma crítica bastante original, muito diferente das demais, que estavam focalizadas na vida do autor e procurando “defeitos” na vida pessoal, na formação e assim por diante.

Em síntese, Aurélio Buarque de Holanda destoa da imagem de Eça com dificuldades para escrever formada pela crítica seminal a fim de construir a imagem do escritor que dominava as formas linguísticas e jogava com elas conscientemente e não por falta de habilidade como anunciou os textos fundadores.

\section{As publicações de caráter bibliográfico}

Apresentam-se, neste momento, as publicações de caráter bibliográfico lançadas no ano de comemoração dos cem anos de nascimento do autor: um ensaio publicado no Livro do Centenário intitulado “Correspondência de Eça de Queiroz para a imprensa brasileira”, de Manuel Bandeira; e dois volumes: Eçaiana, de José Pedro Leite Cordeiro e Eça de Queiroz no Brasil, de Antônio Simões dos Reis.

Tanto o livro de Leite Cordeiro quanto o ensaio de Manuel Bandeira tratam das publicações de Eça de Queirós, diferente de Simões dos Reis, que centra sua pesquisa no levantamento da fortuna crítica sobre o autor português no Brasil. Devido a isso, é necessária a divisão entre o levantamento bibliográfico de Eça e sobre Eça para melhor efeito de análise.

\subsection{O levantamento bibliográfico de Eça de Queirós}

Em 1945, foi publicado, pela primeira vez no Brasil, um livro exclusivo do levantamento cronológico dos textos do escritor português. Eçaiana foi escrito pelo 
médico, genealogista, biógrafo, historiador e membro da Academia Portuguesa de História, da Academia Paulista de Letras e do Instituto Histórico e Geográfico de São Paulo (IHGSP), José Pedro Leite Cordeiro. É a pedido do Instituto que Leite Cordeiro cumpriu a tarefa pioneira de reunir toda a produção do escritor português em um volume.

Conhecido por seu caráter investigativo, Cordeiro foi incumbido de elaborar um registro das publicações de Eça, organizando uma sequência ordenada das publicações em vida e póstumas do escritor. O intuito desse estudo, como afirma Álvaro Soares Brandão na abertura da cronologia, é criar uma “diretriz consciente” (CORDEIRO, 1945, p. 5) que norteasse os estudiosos queirosianos no momento de suas análises, possibilitando a eles visualizar a obra de Eça como um todo. Para isso, Leite Cordeiro divide a Eçaiana em seis partes.

A primeira parte denominada “Cronologia das obras de Eça de Queiroz”, centrando-se no levantamento dos textos escritos por Eça em vida: folhetins, versos, artigos, cartas, contos e romances. Além da data de publicação, Leite Cordeiro faz comentários, geralmente, sobre as publicações de maior impacto, com uma visão historicista marcada na prática de destacar datas, edições e, na prática de atuar como biógrafo, ao aproximar, como os seus antecessores, a vida da obra.

Das publicações do início da carreira de Eça, verifica-se que Cordeiro destaca a publicação do primeiro número do bisemanário Distrito de Évora fundado, como é sabido, pelo autor em 6 de janeiro de 1867. O pesquisador confirma a participação solitária na realização do periódico, o que resultaria na publicação de apenas três números uma vez que perdurara por apenas um semestre. Segundo Leite Cordeiro, os artigos publicados no Distrito revelaram um Eça de grande “capacidade intelectual” (CORDEIRO, 1945, p. 8) e se valendo das palavras de Lopes de Oliveira publicadas nas Páginas Desconhecidas, de 1944, o brasileiro ilustra o valor literário que Eça desenvolvera na fase inicial de sua 
carreira literária da seguinte forma: “Eis a aventura maravilhosa de Eça jornalista: - desde Geraldo Sem Pavor ${ }^{39}$, que Évora não assistira a uma façanha de tal monta” (CORDEIRO, 1945, p. 8). Desse modo, observa-se que, além do levantamento meramente cronológico, Cordeiro faz uma aproximação entre o autor e o personagem Geraldo Sem Pavor, oferecendo à imagem do autor dimensões lendárias.

Cordeiro ressalta a publicação dos primeiros escritos do personagem Fradique Mendes na Revolução de Setembro, de Lisboa, em setembro de 1869. O pesquisador afirma que o personagem iniciara sua produção por meio de versos que, mais tarde, seriam inseridos na introdução da coletânea Prosas Bárbaras por Jaime Batalhe Reis. Como o objetivo dele não é analisar a produção de Eça e sim listá-la, Leite Cordeiro mostra a importância da criação de Fradique, mas não entra na discussão de alteridade e nem sobre os desdobramentos dessa invenção queirosiana.

Cordeiro observa que Eça publicara no Diário de Notícias, de Lisboa, em janeiro de 1870, em três números, as anotações da viagem que ele fizera com o Conde de Resende ao Oriente. A publicação fora intitulada De Port-Said a Suez. Segundo o brasileiro: “As anotações tomadas em três cadernos de bolso e em tiras de papel almaço, foram reunidas, mais tarde, pelo filho do escritor, José Maria de Eça de Queirós Filho, e dadas ao público, em volume, sob o título Egito” (CORDEIRO, 1945, p. 9). Mais especificamente, as anotações de viagem O Egito foram publicadas em 1926.

Leite Cordeiro assinala também a publicação, juntamente com Ramalho Ortigão, de O Mistério da Estrada de Sintra, inicialmente, publicado em folhetins e depois em volume,

\footnotetext{
39 Geraldo, personagem lendário da história portuguesa na época das lutas da Reconquista, ficou conhecido, desde o século XII, pelo nome de Geraldo Sem Pavor.
} 
primeiramente em 1885, além de mencionar na década de 1940 duas traduções espanholas $^{40}$.

Cordeiro revela que em 1871 fora publicado em janeiro um anúncio no Diário de Notícias sobre uma publicação de um romance de Eça intitulado História de um lindo corpo que, como é sabido, nunca foi publicado.

Em consonância com isso, o estudioso brasileiro faz uma ponte com a conferência preferida por Eça no mesmo ano intitulada A Nova Literatura ou O Realismo como nova expressão de Arte, destacando o ano de 1871 como um marco significativo na trajetória do escritor realista.

Em 14 de abril de 1877, de acordo com Cordeiro, Eça iniciara a escrita de as Cartas de Londres no jornal da cidade do Porto A Atualidade. Essa participação durara, aproximadamente, um pouco mais de um ano, encerrando suas atividades em 21 de maio de 1878. E nesse ano, como é sabido, Eça publicara O Primo Basílio que, curiosamente, Cordeiro informa que chamaria inicialmente de O Primo João Carlos. Além disso, ressalta que até 1942 já havia 17 edições do Primo e traduções para o espanhol, o inglês, o francês, o alemão, o holandês e o sueco. Verifica-se que esse número considerável de traduções supera, no mesmo período, as do Crime, o que demonstra a superioridade, do ponto de vista da recepção, do segundo romance sobre o primeiro. E também sobre isso, Cordeiro resgata uma citação de Camilo Castelo Branco sobre o Primo: “É o romance mais doutrinal que ainda saiu dos prelos portugueses. Doutrinal escrevi como Moralizador" (CORDEIRO, 1945, p. 13). E além da publicação do Primo, Cordeiro destaca a preparação das Cenas Portuguesas, uma coletânea de 12 volumes que nunca fora concluída, mas o material fora reaproveitado para a publicação de Os Maias.

\footnotetext{
${ }^{40}$ Lembrando que os dados levantados por Leite Cordeiro se encerram em 1945 uma vez que é sabido que a obra queirosiana alcança hoje um número maior de edições e traduções.
} 
Referente à 1879, Cordeiro considera uma tentativa de Eça publicar outro texto intitulado $O$ Conde de Abranhos, que acertadamente o brasileiro o coloca nas publicações póstumas, uma vez que foi levado ao público em 1925. Em vista disso, não se pode deixar de citar Carlos Reis sobre essas suspensões bem lembradas por Cordeiro:

No caso do espólio de Eça de Queirós, a situação é, como se sabe, complexa e diversificada, uma vez que nele se encontram materiais que cobrem um arco de atitudes e de momentos escriturais muito amplo. Da recolha incipiente e informe de elementos estruturantes da narrativa (como as personagens apenas elencadas e mal caracterizadas) à transcodificação pela escrita de uma adaptação teatral de um romance, são variadas as situações que se nos deparam. Várias delas correspondem a esboços (digamos assim) que estariam, pela sua natureza, condenados a permanecer para todo o sempre materiais de trabalho reservados, muito aquém de qualquer hipótese de publicação; outros encontram-se em momento de elaboração já consideravelmente adiantado, mas ainda assim tão isentos de problemas e de dificuldades, como é eloquentemente evidenciado pelas desastrosas publicações póstumas [...] (REIS, 2002, p. 26).

Para os anos que iniciam a década de 80 do século XIX, Cordeiro realiza um breve percurso e salienta os bastidores da polêmica entre Eça e Pinheiro Chagas e como isso repercutiu em trocas de artigos no jornal O Atlântico, de Lisboa nos anos de 1880 e 1881. Também na década de 1880, o pesquisador enfatiza a publicação dos primeiros prefácios escritos por Eça e os coloca assim: o primeiro, Azulejos, de Bernardo Pindela; e, o segundo, O Brasileiro Soares, de Luiz de Magalhães. Com relação a essa informação, Beatriz Berrini (1997), apresenta outra ordem de publicação colocando o prefácio sobre o texto de Magalhães em primeiro lugar afirmando que esse livro

foi o primeiro, em ordem cronológica, a merecer a palavra do romancista. O casamento de Eça, no mesmo ano em que o livro era publicado, explicará em parte a sua decisão de escrever um prefácio para ele, pois Luiz de Magalhães, além de um bom companheiro, era muito amigo da família de sua mulher (BERRINI, 1997, p. 114). 
Em 1887, depois de alguns anos sem publicar romances, Eça retornaria com $A$ Relíquia, que Cordeiro informa que em Portugal a publicação se dera em volume editado pela Editores Lello-Porto e no Brasil em forma de folhetim na Gazeta de Notícias. E, nesse mesmo ano, Eça prefaciara o livro de Joaquim de Araújo denominado Luis de Camões.

Sobre o ano seguinte, o estudioso brasileiro retoma a querela entre Eça e Pinheiro Chagas da seguinte forma:

Carta de Eça de Queirós a Mariano Pina, referente ao Prêmio D. Luís, e dirigida ao O Repórter (Lisboa), jornal orientado por Oliveira Martins. A carta só veio a ser publicada em maio. Era um comentário ao parecer do júri, assinado por Pinheiro Chagas que a 7 de fevereiro foi a vítima de uma agressão, vindo quase a falecer em razão das lesões sofridas. A polêmica mantida por Eça de Queirós com Pinheiro Chagas foi efeito de exclusão de A Relíquia, do prêmio instituído por El-Rei D. Luís (CORDEIRO, 1945, p. 15-16).

Ainda em 1888, Cordeiro ressalta a “trágica e interessante” (CORDEIRO, 1945, p. 16) publicação de Os Maias, que sofrera atraso pela Tipografia Lallemant. Com relação a isso, o brasileiro descreve qual foi a atitude de Eça: “após esperar mais um ano, o autor apelou para a Casa Chardron que adquiriu os originais, os quais sofreram muitas correções durante quatro anos, sendo publicados somente em 1888” (CORDEIRO, 1945, p. 16). Até o fim de seu estudo, o brasileiro notabiliza 16 edições, sendo uma ilustrada e uma tradução para o espanhol. Em 1888, Eça iniciara a publicação de As Cartas de Fradique Mendes em O Repórter, de Lisboa.

Em 1889, Cordeiro destaca uma resposta de Eça à Bulhão Pato ${ }^{41}$ no jornal $O$ Tempo, de Lisboa e, daí por diante, o autor passaria a ser conhecido como polemista.

\footnotetext{
${ }^{41}$ Arnaldo Faro relata esse episódio assim: "Os Maias deram causa a uma polêmica triangular: Pinheiro Chagas e Bulhão Pato contra Eça. O início foi no Rio de Janeiro, no jornal O País. Em crônica ali publicada, Pinheiro Chagas denunciava ter Eça de Queirós retratado, no poeta Tomás de Alencar, o poeta Bulhão Pato, e falava de uma sátira, 'direta e crudelíssima', com que Pato respondera a Eça” (FARO, 1977, p. 192). E essa polêmica continuou em $O$ Tempo, de Portugal.
} 
Em 1895, ressalta a presença do escritor português como fundador e diretor de $O$ Almanaque Enciclopédico e a sua participação na Revista Moderna, de Paris, em que publicara os contos “A Perfeição” e “José Matias”. Nesse mesmo periódico, foi anunciada a publicação de A Ilustre Casa de Ramires, mas o brasileiro afirma que, no formato de volume, esse romance surgiria somente em 1900, mencionando que a revisão fora dividida entre Eça e João Barreira. Ele também contabiliza, até 1945, 12 edições e uma tradução espanhola do texto.

No ano do falecimento de Eça, Cordeiro centra-se na discussão a respeito da autoria do Dicionário de Milagres, que é constituído por um conjunto de milagres, organizados alfabeticamente, mas está incompleto possuindo apenas as letras A e B. Esse dicionário é uma quase tradução de um Dictionary of Miracles, que o próprio Eça possuía. Nota-se que Cordeiro faz uma pesquisa aprofundada sobre esse tópico e insere algumas citações que levantam dúvidas sobre o motivo da realização desse dicionário por parte de Eça. No geral, acredita-se que fora um empreendimento para melhorar a sua vida financeira, o que resultara no artigo publicado por Timóteo da Silva Bastos, autor do prefácio dessa obra, que mostra, posteriormente, total arrependimento por ter "participado" nela, achando-a um disparate com fins lucrativos, pois Eça teria recebido um adiantamento.

Cordeiro encerra a sua primeira parte com a publicação de A Cidade e as Serras de 1901, lembrando que Eça não havia concluído a revisão e que Ramalho Ortigão fora convidado para revisar o que estava faltando. Sobre esse romance, o nosso pesquisador notabiliza 20 edições e uma tradução para o espanhol.

Na segunda parte denominada "Livros prefaciados por Eça de Queiroz", o estudioso brasileiro retoma o assunto afirmando que o escritor português prefaciara quatro livros: o primeiro, Azulejos (1886), de Bernardo Pinheiro Pindela; o segundo, Brasileiro Soares (1886), de Luís de Magalhães; o terceiro, Luís de Camões (1887), de Joaquim de 
Araújo; e o quarto e o último, Aquarelas (1889), de João Diniz. Nota-se que ele repete o mesmo erro ao colocar a publicação do prefácio do Azulejos num primeiro momento e, além disso, insere na cronologia dessa parte a carta-prefácio para Luís de Camões, que Beatriz Berrini (1997) não considera, provavelmente, como um prefácio ensaístico. Outro fato que chama a atenção é a omissão do prefácio à Aquarelas na primeira parte, quando faz a apresentação dos textos de Eça em geral.

$\mathrm{Na}$ terceira parte denominada “Trabalhos de Eça de Queiroz feitos em colaboração”, Cordeiro, além de citar novamente O Mistério da Estrada de Sintra, retoma o romance agora para abrir a sequência de textos escritos por Eça juntamente com colaboradores. O estudioso brasileiro cita mais dois: Um feixe de Penas (1885), que é uma “coleção de artigos e poesias editadas em benefício do 'Asilo para Raparigas Abandonadas”” (CORDEIRO, 1945, p. 22); e As Farpas (1871-1872) com Ramalho Ortigão, que define como "opúsculos mensais de crítica e observação da sociedade portuguesa” (CORDEIRO, 1945, p. 22).

$\mathrm{Na}$ quarta parte denominada “Jornais, revistas e publicações em que Eça de Queiroz colaborou”, Cordeiro elabora uma sequência em ordem alfabética dos nomes dos periódicos onde Eça publicara textos. O brasileiro afirma que o escritor participou de 17 periódicos em Portugal, transitando por Vila Nova de Familiação com A Alvorada; no Porto com A Atualidade e Revista de Portugal; em Évora com o Distrito de Évora; e em Lisboa na grande maioria: Atlântico, Diário de Notícias, Diário de Portugal, As Farpas, Gazeta de Portugal, A Ilustração, Renascença, O Repórter, A República, Revista Ocidental, Revolução de Setembro, O Tempo e A Vitória da República; e, fora de Portugal, o escritor tivera três participações: duas em Paris com Nouvelles Literaires e Revista Moderna; e a última no Rio de Janeiro, na Gazeta de Notícias. 
Nessa parte ocorre apenas o levantamento dos nomes dos periódicos sem a data de participação de Eça e sem nenhum outro comentário já que, na primeira parte, Cordeiro já havia realizado alusões a essas publicações, embora não tenha citado a participação de Eça em A Alvorada, Nouvelles Literaires, A República e A Vitória da República, o que sugere que o estudo de Cordeiro não está completo. Quem, no mesmo ano, faz um aprofundamento em relação às publicações folhetinescas de Eça é Manuel Bandeira.

Em ensaio publicado no Centenário, o poeta brasileiro recupera as publicações do escritor português na Gazeta de Notícias, do Rio de Janeiro, entre 1880 e 1897. Diferente de Cordeiro, que faz um percurso geral e sem profundidade sobre a obra queirosiana, Manuel Bandeira faz um levantamento bibliográfico detalhado dessas publicações com datas, títulos e comentários mais sistemáticos. O estudo empreendido pelo brasileiro é tão significativo que, segundo Elza Miné (2008), do estudo de Manuel Bandeira “se serviu Guerra da Cal, na sua monumental Bibliografia Queirociana” (MINÉ, 2008, p. 159), o que revela a importância do ensaio do poeta dentro da fortuna crítica eciana.

Manuel Bandeira descreve o papel da Gazeta de Notícias como veículo comunicativo inovador e de destaque no jornalismo brasileiro no século XIX. Ele enfatiza também a credibilidade do jornal que conseguia colaboradores nacionais como Machado de Assis, Aluísio de Azevedo; e estrangeiros como Oliveira Martins, Eça de Queirós, Ramalho Ortigão.

O poeta nota que Eça passa a chamar atenção do público brasileiro por meio da publicação de $O$ Primo Basílio e a glória foi a repercussão que ela causara que viabilizou sua colaboração no periódico brasileiro. A discussão em torno do Naturalismo povoara a Gazeta de Notícias, dando ênfase constante a Eça e, cada vez mais, os seus textos assumiam lugar primordial nas publicações do jornal. 
Até o estudo de Manuel Bandeira não havia uma sequência cronológica da colaboração de Eça na Gazeta e, por isso, ele empreende o trabalho de colocá-las em ordem e afirma que essa organização "será interessante ao estudo da evolução das ideias e sentimentos do escritor alistá-las segundo as datas de sua publicação, o que passamos a fazer ano por ano” (BANDEIRA, 1945, p. 169).

Passo a passo, Bandeira faz a cronologia dos textos de Eça, desvendando datas, silêncios, exclusividades, comentários, recepção, correspondências, debates, que enriqueceram seu ensaio tanto no âmbito da crítica literária quanto no âmbito bibliográfico.

Manuel Bandeira vê a participação de Eça na Gazeta de Notícias não simplesmente como um correspondente jornalístico noticiando fatos da Europa, mas, sobretudo, como um provocador de ideias que giram em torno da política, da moral, da liberdade e da arte. O brasileiro afirma que, nos textos de Eça, há o retrato da civilização capitalista e imperialista do século XIX, direcionado pelo amor cego que o autor português tinha pelas culturas francesas e inglesas. O brasileiro observa que a atenção carinhosa não é dada a América, uma vez que Eça “jamais tomou conhecimento do esforço cultural desse continente” (BANDEIRA, 1945, p.101). Segundo Elza Miné (2008), Bandeira não entendia o motivo do autor português se dirigir aos americanos com expressões tão pejorativas como “leviana ignorância”, “compreensão limitada”, “piores juízos”, moldando o cidadão da América de maneira primitiva.

Manuel Bandeira demonstra espanto ao comentar o que entende ser o desconhecimento de Eça sobre o Brasil, porque, como aponta o poeta, o escritor português via “o Brasil de Eça como o Brasil de Ramalho, era o Brasil do seu amigo Eduardo Prado, esse fanático monarquista, que, aludindo ao 'Grito do Ipiranga', a tela de Pedro Américo, onde há dois caipiras que passaram para a cena histórica” (BANDEIRA, 1945, p. 181). 
Assim, além de ser um ensaio a respeito das publicações queirosianas na Gazeta, é um ataque de Manuel Bandeira contra a visão de Eça sobre a América. A crítica do brasileiro se justifica, especialmente, em função das críticas do escritor português ao Novo Mundo.

Por isso, o ensaio de Bandeira aguça duas leituras: uma primeira, que mostra o mapeamento das publicações de Eça no periódico nacional e, uma segunda, que revela um debate identitário. Ambas tratadas com maestria: a primeira gera um dado exato e a segunda, uma polêmica que até hoje instiga os queirosianos.

Porém, diferente de Manuel Bandeira, Leite Cordeiro não pára nas publicações de Eça em periódicos e elabora uma quinta parte denominada “Obras de Eça de Queiroz editadas após sua morte”. O estudioso brasileiro reúne todas as publicações póstumas de Eça, a maioria revisada pelos filhos. Outros textos são cartas do escritor português, comentando momentos de sua vida e da sua produção literária. Têm-se, também, compilações de seus textos, principalmente nos periódicos. Utilizando o mesmo método da primeira parte. Cordeiro faz um levantamento das datas, dos nomes dos responsáveis pelas publicações e das outras edições, contando 19 publicações póstumas distribuídas em dois grupos: o primeiro, de textos publicados pelo próprio Eça e que foram reunidos em volumes; e, o segundo, de obras terminadas pelo escritor português, porém inéditas.

Observa-se que Leite Cordeiro vai além de suas incumbências. Mais do que realizar a cronologia completa da produção de Eça, ele inclui sua visão acerca das publicações, trazendo informações contextuais a respeito de uma ou outra publicação. 


\subsection{O levantamento bibliográfico sobre Eça de Queirós}

Antônio Simões dos Reis é conhecido pelo trabalho como bibliógrafo de produções nacionais em geral. Destaca-se pelo levantamento que realizou dos poetas brasileiros, escrevendo 40 volumes de informação bibliográfica sobre cada poeta, mas sendo, infelizmente, publicados apenas dois volumes. Ele é responsável por publicar, pela Livraria Editora Zélio Valverde, do Rio de Janeiro, um estudo sobre a bibliografia de publicações brasileiras sobre Eça de Queirós, lançada no ano de comemoração dos cem anos de nascimento do escritor português intitulado Eça de Queiroz no Brasil. Esse trabalho foi o mais completo do gênero no país “mostrando um Eça como foi visto no Brasil e como repercutiu por aqui” (REIS, 1945, p. 8).

O bibliógrafo salienta que o livro sobre Eça não é um trabalho definitivo e serve basicamente como um "lençol” para os estudiosos queirosianos. Simões dos Reis faz um levantamento detido e minucioso da crítica queirosiana publicada no Brasil, percorrendo jornais, revistas, prefácios de livros, cartas, verbetes de enciclopédias, palestras, partes de livros, livros e reedições de livros que surgiram até 1945.

No total, Simões dos Reis realiza o levantamento de 309 publicações sobre Eça no Brasil desde supostamente a primeira em 1878, realizada por Machado de Assis, até as últimas de 1945. O quadro é o seguinte segundo o brasileiro: 


\begin{tabular}{lccccccccc} 
PERÍODO & \multicolumn{10}{c}{ PUBLICAÇÕES } \\
& Artigo & Prefácio & Carta & Verbete & Palestra & Parte de Livro & Livro Reedição \\
Séc. XIX & 22 & 0 & 2 & 0 & 1 & 3 & 0 & 0 & 28 \\
1900 & 38 & 0 & 3 & 0 & 2 & 0 & 0 & 0 & 43 \\
$1901-1909$ & 15 & 0 & 1 & 0 & 0 & 8 & 0 & 0 & 24 \\
Dec. 10 & 2 & 0 & 1 & 0 & 0 & 8 & 0 & 0 & 11 \\
Dec. 20 & 4 & 0 & 1 & 0 & 0 & 8 & 0 & 0 & 13 \\
Dec. 30 & 46 & 0 & 0 & 0 & 0 & 22 & 2 & 0 & 70 \\
1940-1945 & 60 & 1 & 2 & 2 & 1 & 22 & 3 & 1 & 92 \\
s.d. & 6 & 6 & 0 & 0 & 0 & 16 & 0 & 0 & 28 \\
TOTAL & $\mathbf{1 9 3}$ & $\mathbf{7}$ & $\mathbf{1 0}$ & $\mathbf{2}$ & $\mathbf{4}$ & $\mathbf{8 7}$ & $\mathbf{5}$ & $\mathbf{1}$ & $\mathbf{3 0 9}$
\end{tabular}

Em porcentagem, tem-se o seguinte resultado:

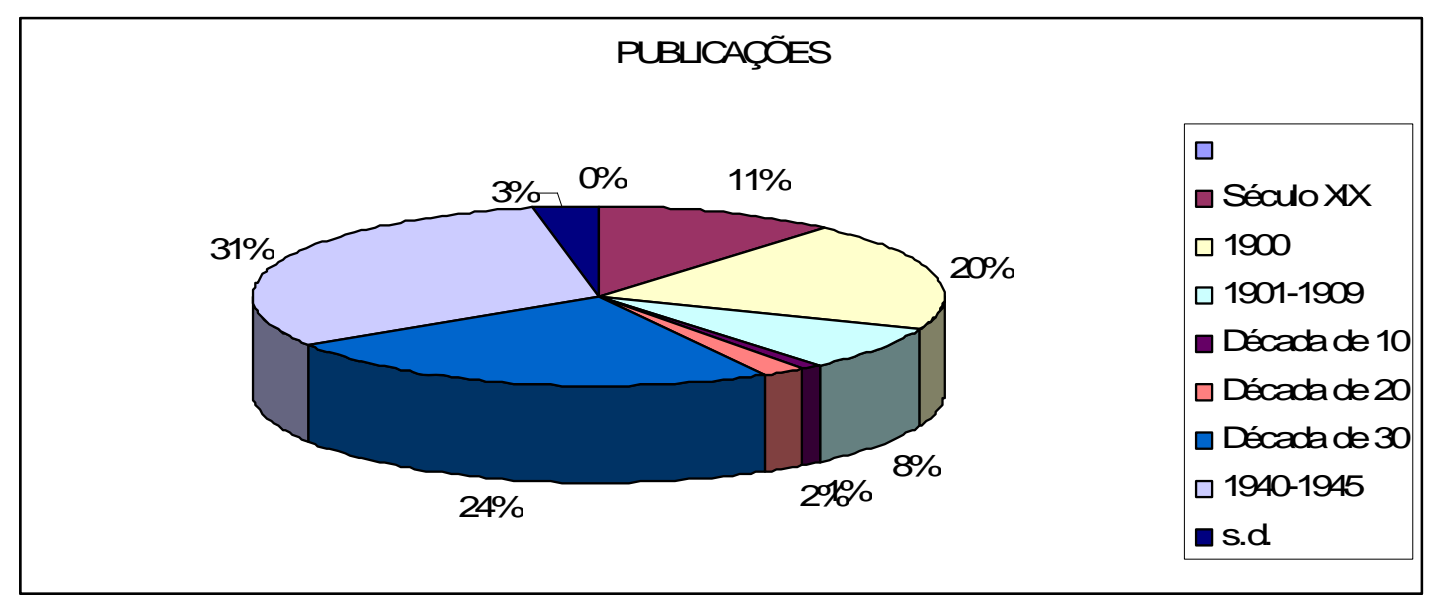

Verifica-se que a bibliografia sobre Eça vive momentos altos e baixos no período estudado pelo bibliógrafo. Partindo das publicações decorridas durante a segunda metade do século XIX, mais precisamente a partir de 1878, Eça recebe, até 1899, o total de 28 textos distribuídos da seguinte forma: uma palestra transcrita, duas cartas, três partes de livros e 22 artigos de periódicos. Durante 21 anos, o Brasil publica pelo menos um texto 
sobre Eça por ano, assinalando que Eça ainda estava produzindo literatura e nem todas as suas obras já tinham sido publicadas.

No ano do falecimento do escritor português em 1900, as publicações sobre ele praticamente dobraram em apenas meses de publicações. Isto é, a morte de Eça virara um acontecimento literário e histórico e muitos textos surgiram como se observa a seguir: duas palestras transcritas, três cartas e 38 artigos de periódicos. Somando 43 publicações, os brasileiros souberam como ninguém homenageá-lo, pois de agosto (mês exato da morte) até dezembro de 1900 (somando cinco meses), o Brasil publicara praticamente sete textos por mês sobre o autor realista.

Da numerosa publicação de textos sobre Eça em 1900, na década que iniciaria o século XX, esse número cai quase pela metade sendo publicados de 1901 a 1909, 24 textos: uma carta, oito partes de livros e 15 artigos de periódicos. Essas publicações, apesar de representarem um número menor, provavelmente aconteceram em meio às publicações dos textos póstumos do escritor português, que mantiveram, de certa forma, a figura de Eça viva e presente com praticamente duas publicações anuais.

Na década de 10, esse quadro se agrava e somente 11 textos foram publicados: uma carta, oito partes de livros e dois artigos de periódicos. Se comparar com o século XIX, chega-se ao mesmo número de publicações por ano (uma), mas se pensar que na década de 1910 o meio editorial estava mais desenvolvido, as publicações, na verdade, foram limitadas.

No levantamento de publicações da década de 10, Simões Reis não cita a publicação de Eça de Queiroz (1911), de Miguel Melo, livro inaugural e pioneiro sobre Eça. Essa “omissão” 42 permite inferir que os dados de Reis não apresentam, com exatidão,

\footnotetext{
${ }^{42} \mathrm{O}$ questionamento está restrito às publicações em formato de livro uma vez que o corpus deste estudo são as publicações em volume.
} 
o número de publicações sobre Eça no Brasil. Na realidade, quem o soube fazer com mais precisão, anos depois, foi Guerra da $\mathrm{Cal}^{43}$.

Na década de 20, o quadro se manteve e somente 13 publicações se deram, sendo praticamente uma por ano também: uma carta, oito partes de livros e quatro artigos de periódicos. Comparando as publicações do século XIX com as décadas de 10 e 20, os tipos de publicação mudaram. Se antes a maioria das publicações se dava por meio de artigos, nas décadas iniciais do século XX, houve o aumento de publicações de partes de livros, alcançando finalmente a publicação de um livro inteiro sobre a vida e a obra de Eça. Esse levantamento bibliográfico sobre o escritor português revela o próprio desenvolvimento dos meios de comunicação do Brasil, principalmente do livro ${ }^{44}$.

Revertendo esse quadro, na década de 30, antecipando as comemorações do centenário de nascimento do escritor, as publicações quase dobraram em comparação com o ano da morte de Eça, alcançando 70 publicações, o que possibilita afirmar que além de mostrar a evolução dos meios de comunicação no Brasil, mostra a evolução da própria crítica literária que se apresenta mais madura e produtiva. A distribuição das publicações se dá da seguinte forma: 46 artigos de periódicos, 22 partes de livros e dois livros. Tem-se, portanto, o dobro de publicações desses gêneros em vista de publicações anteriores.

Se, na década de 30, o aumento é considerável; na década em que se comemoraram os cem anos de nascimento de Eça (1945) é outro acontecimento editorial, literário e histórico. Nos cinco anos levantados por Simões Reis (1940-1945), foram publicados 92 textos, isto é, quase 20 publicações anuais em média. A vida e a obra de Eça retomaram o brilho dos tempos da ecite e, no Brasil, falar, imitar e consagrar os diversos personagens de Eça vira “moda”. As 92 publicações são distribuídas da seguinte forma: uma palestra, duas

\footnotetext{
${ }^{43}$ Cf. GUERRA DA CAL, Ernesto. Língua e estilo de Eça de Queiroz. 8. ed. São Paulo: EDUSP/ Rio de Janeiro: Tempo Brasileiro, 1969.

${ }^{44}$ Cf. HALLEWELL, Laurence. O livro no Brasil: sua história. São Paulo: T.A. Queiroz, 1985.
} 
cartas, dois verbetes de enciclopédia, um prefácio, uma reedição de livro (no caso, de Viana Moog, de 1938), 60 artigos de periódicos, 22 partes de livros e três livros. Pela primeira vez, surgem publicações de gêneros textuais que ainda não tinham aparecido, como o verbete e o prefácio, antecipando o processo natural das publicações que foram evoluindo com as transformações na produção escrita e com o advento dos meios de comunicação, que, mais tarde, seria responsável pelas adaptações de textos de Eça tanto para a televisão quanto para o cinema. Contudo, Simões Reis deixa mais uma vez de citar publicações de livros, no caso, não apresentando três dos seis ${ }^{45}$ livros publicados entre 1940 e 1945 sobre Eça no Brasil. Ele se centrou em três livros (dois de brasileiros e o outro de um argentino que teve a publicação no Brasil): Os tipos de Eça de Queiroz (1940), de Melo Jorge, Eça de Queiroz (1942), de Clóvis Ramalhete e Projeção universal de Eça de Queiroz (1943), e do argentino Sílvio Julio.

Reis também faz o levantamento de 28 publicações sem data específica distribuídas desse modo: seis prefácios, seis artigos de periódicos e 16 partes de livros.

Enfim, mesmo detectando algumas falhas no levantamento bibliográfico sobre Eça no país, a pesquisa de Simões Reis apresenta o resultado da recepção do autor realista no Brasil comprovando que o escritor mantivera depois de décadas de sua morte a chama de sua presença por meio de seus textos e de outros que lhe fizeram homenagem.

Os três estudos de caráter bibliográfico surgem em um momento em que existia pouco interesse em desenvolver a imagem de Eça longe do artista talentoso. Assim, Leite Cordeiro, Manuel Bandeira e Simões Reis apresentaram as diferentes habilidades de Eça

\footnotetext{
${ }^{45}$ Verifica-se que Simões Reis não cita os livros e coletâneas que foram publicados no mesmo ano do seu texto, por isso cogita-se a hipótese de que ele não tomou conhecimento dessas publicações, porque, possivelmente, ainda estariam no prelo enquanto ele publicava o seu estudo.
} 
na escrita, mostrando o lado jornalista, ensaísta, prefaciador, contista, cronista e romancista com base na própria produção do autor e sua fortuna crítica no Brasil, rompendo com a crítica seminal, que se centrou exclusivamente na formação do artista.

\section{A linguagem queirosiana como instrumento social}

O pensamento crítico e filosófico de Eça de Queirós, pouco desenvolvido pela crítica seminal, toma fôlego com o livro Crítica social de Eça de Queiroz (1950), de Djacir Meneses, que observa a posição do autor perante os movimentos ideológicos de sua época por meio de uma interpretação da produção literária do escritor como força enraizada em componentes proudhonianos e em um socialismo político.

Para Meneses, se afastando da crítica seminal, o aspecto principal da obra de Eça é o que chamavam de "fundo" e não de "forma", como se defendeu anteriormente. A obra queirosiana "vale antes de tudo pelo conteúdo de crítica social: crítica à educação, crítica ao clericalismo, crítica à política, à organização da família, ao servilismo literário, à dissolução dos costumes políticos, à pasmaceira geral da pátria [...]” (MENESES, 1970 [1ª . ed. 1950], p. 46) ${ }^{46}$ do que pela forma que escrevera.

Ao tomar a obra de Eça nessa perspectiva, Djacir Meneses transita pela abordagem marxista, especialmente na aproximação que realiza entre os elementos sociais e a linguagem: "Nada leva a um conhecimento mais íntimo dos fatos sociais, revelando-nos o aspecto interior de uma cultura, do que o estudo da linguagem” (MENESES, 1970 [1 ${ }^{\text {a }}$ ed. 1950], p. 23). Nessa afirmação do estudioso, observa-se a defesa de uma definição de

\footnotetext{
${ }^{46}$ Segundo Djacir Meneses, ele não fez nenhuma alteração na $3^{\text {a }}$ edição com relação à segunda edição, que para ele, definitivamente seria a primeira devido à tiragem de apenas 350 exemplares da edição de 1950: “Abstive-me de qualquer alteração no presente texto, mesmo relativamente a passagens que me solicitavam novas reflexões. Em três decênios e tanto, mudaram as perspectivas, e, evidentemente, as ideias que permitem interpretá-las” (MENESES, 1970 [1ª . ed. 1950], p. 20).
} 
linguagem como fenômeno sócio-histórico e, portanto, considera mais importante analisar a obra de Eça partindo do estudo das marcas contextuais do que como um fenômeno independente, ligado à pessoa do artista, como grande parte da crítica seminal fez. Para Meneses:

a literatura, que é experiência social no grau mais alto, denuncia o estado de desenvolvimento da consciência coletiva e dos grupos, das suas lutas por objetivos socialmente configurados em condições de existência definidas; e a linguagem, que é o fundo comum sobre que trabalha o escritor, com seu repositório de imagens, de ideias, de concepções, de emoções, é um processo de cunho histórico, que se desenvolve no concurso das gerações que organizam a convivência na atmosfera cultural herdada e dentro de condições definidas (MENESES, 1970 [1 $1^{\mathrm{a}}$. ed. 1950], p. 31).

Meneses aproxima a estrutura social da estrutura da linguagem. No jogo dialético observado pelo brasileiro à respeito da produção escrita de Eça, a palavra é tomada como um elemento determinante que está ligado ao campo social, tal como a define Mikhail Bakhtin:

Ao orientar a sua palavra a partir do seu interlocutor, o falante constitui a sua subjetividade considerando o seu outro. Esse processo funciona como um espelho em que o falante busca refletir-se, daí o fato de a palavra ter dupla face, pois é determinada tanto pelo fato de preceder de alguém, como por dirigir-se a alguém. Podemos afirmar, assim, que a sua existência está intrinsecamente ligada à realidade social, fora do contexto de uso é destituída de sentido. A palavra é uma arena em miniatura onde se perpassam e lutam os valores sociais de orientações contraditórias. É a partir do momento em que o sujeito falante entra nessa corrente ideológica, uma vez que a palavra é um signo ideológico por excelência, que constrói a sua visão de mundo. Neste sentido, a palavra, quando proferida, traz as marcas inalienáveis da vida (BAKHTIN, 1995, p. 49).

Nota-se que a valorização de Meneses sobre a escrita de Eça está no fato de ele ter conseguido dar sentido ao texto literário de modo a espelhar os conflitos da realidade social portuguesa e europeia do final do século XIX. Interpretando a obra do escritor 
português desse ponto de vista, o que o brasileiro faz é focalizar não a vida de Eça, mas o seu texto como expressão de seu momento histórico, todavia, não abandona totalmente a figura do artista, já que refletia sobre como o "pensamento individual se embebe no pensamento social, que é o aspecto ideológico do desenvolvimento das relações humanas consideradas em conjunto, como totalidade. Os sistemas de pensamento têm, portanto, a sua história” (MENESES, 1970 [1ª. ed. 1950], p. 180). Além disso, para o brasileiro, era necessário que Eça discutisse a realidade de seu tempo, porque ele vivera em um momento em que se encorajava o homem de pensamento.

O estudioso brasileiro vê a literatura de Eça como um instrumento educativo e afirma que o autor tinha conhecimento desse valor didático de sua escrita. Sobre isso, comenta:

Diz-nos Eça, no prefácio de Azulejos, do Conde de Arnoso, que o escritor moderno não vem ao público com maneirismos delicados, usando os punhos de renda de $\mathrm{M}$. Buffon, dirigindo-se a um leitor que era fatalmente aristocrata. A democracia, com as máquinas rotativas aperfeiçoadas, barateou o livro, promoveu a alfabetização, e o público virou uma entidade enorme, numerosa, complicada, tumultuosa de aspirações e instintos. O livro - considera Eça - deixou de ser a obra de arte, lavorada e fina, que mãos delicadas delicadamente folheavam, no recolhimento dos gabinetes. Hoje, é o instrumento das ideias e dos interesses amplificados pela burguesia e frações das camadas operárias... (MENESES, 1970 [1 $1^{\text {a }}$ ed. 1950], p. 187).

Com relação a isso, Meneses ressalta que a criação da galeria de tipos criada por Eça surgira para dar conta desse aspecto didático que o autor sentira necessidade de inserir em sua obra: “A literatura de Eça representa a literatura no sentido mais salutarmente social: é instrumento de análise e condensa, como a dos verdadeiros artistas, uma experiência de límpido valor sociológico” (MENESES, 1970 [1ª ed. 1950], p. 190). Nessa perspectiva sociológica, então, Djacir Meneses entende que a obra de Eça é fruto da 
sociedade que a compõe e que, por sua vez, recebe sua "influência" ${ }^{47}$. Daí a inovação por parte do brasileiro que apresenta uma necessidade histórica do autor português retratar a realidade de Portugal.

Ao defender a linguagem como elemento determinante do campo social, Djacir Meneses considera o francesismo de Eça um aspecto positivo da sua escrita, pois, por meio dele, o autor conseguira renovar sua linguagem e ampliar horizontes.

Seu espírito [Eça] e o de sua geração não poderiam ser contidos nos limites de uma literatura fradescamente isolada do mundo europeu, embasbacada diante de Castilho e de seus afilhados. Voltaram-se para a literatura francesa, que o naturalismo renovara, como para um respiradouro. Ela lhes amplificou os horizontes. Deu-lhes o oxigênio para o desenvolvimento espiritual. Que pequenez crítica a dos críticos que se escandalizaram com seus galicismos e sua ignorância da língua! Era inevitável que assim fosse - ou não seria Eça de Queirós, mas um Bulhão Pato, um brigadeiro Chagas [...] (MENESES, 1970 [1 $1^{\mathrm{a}}$. ed. 1950], p. 44).

No excerto, observa-se a crítica ferrenha realizada por Djacir Meneses ao posicionamento crítico da época de Eça, que não vira com bons olhos a aproximação do autor português com a literatura francesa. Essa visão distorcida da presença estrangeira na obra de Eça foi tomada de forma reiterada pelos queirosianos do início do século XX, que também não compreenderam como essa aproximação ampliara a obra do autor. À vista disso, Meneses inaugura uma visão inovadora dessa relação destacando que foi a maneira encontrada por Eça para que ele "se realizasse” dando-lhe “os instrumentos expressionais da audácia” (MENESES, 1970 [1ª. ed. 1950], p. 45). Ele repudia a visão de Eça como “combatente fatigado e desiludido” (MENESES, 1970 [1ª. ed. 1950], p. 54) e abre espaço para um Eça que não renunciara a sua escrita inicial nas últimas publicações.

\footnotetext{
${ }^{47}$ Cf. CANDIDO, Antonio. Literatura e sociedade. São Paulo: Editora Nacional, 1985.
} 
Dando continuidade a sua crítica de intervenção, Meneses é contrário à análise psicológica da obra de Eça, que a reduzia a uma mera construção sucessiva de “complexos”.

Quantas oportunidades para coisas eruditas! Convicções científicas, educação literária, inteligência aguçada volvida aos problemas de sua época, tudo isso desandou a plano secundário ou apenas a função de complemento da determinante fundamental: filho abandonado, nervoso, sem carinhos maternais, com o complexo agindo. As suas criações femininas são marcadas do estigma: Luísa, Leopoldina, Maria Eduarda, Gracinha Ramires, as Lolas, a Gouvarinho, insatisfeitas e adúlteras. Era a vingança do subconsciente, - o romance neurótico purgando um complexo da infância. Não era a sociedade, com educação viciada e falha [...], que formava aqueles tipos decalcados em uma matriz. Aqueles tipos não nascem na sociedade; passam a nascer do subconsciente de Eça e de seus "conflitos". Que forma astuciosa de absolver a sociedade e desviar a solução do problema para o próprio romancista! Ainda aqui deparamos a tática que surpreendemos anteriormente. É que o estratagema é fundamental - e velho (MENESES, 1970 [1 $1^{\mathrm{a}}$. ed. 1950], p. 65-66).

Mediante a veia irônica típica de Eça, Djacir Meneses mostra que a análise psicológica retirava da produção queirosiana todo o seu valor estético e social, uma vez que a concebia como um desabafo do escritor, uma "vingança”, como ele próprio afirma no trecho (talvez fazendo uma referência ao estudo de Viana Moog que propôs inicialmente esse caráter vingativo da obra de Eça) perante a sociedade portuguesa. Para Meneses, qualquer apontamento de Eça tinha que ser lido pela perspectiva social e política. Inegavelmente, o brasileiro traz novas respostas sobre Eça ao ressaltar que “a arte é um aspecto do comportamento social do homem” (MENESES, 1970 [1 $1^{\text {a }}$ ed. 1950], p. 190) e que, diferente do sociólogo que desenvolve um texto científico, o artista traz o lado humano das relações sociais.

Coube à literatura o papel mais importante na revelação da natureza humana e precedeu à investigação científica. Literatura no sentido mais altamente antropológico e sociológico do termo. Sentido de força social, 
que conduz sempre algo de vivo, de vitalizante; que não repete mas revela; que não deseja restaurar o que morreu, mas incentivar o que germina e frutifica (MENESES, 1970 [1ª. ed. 1950], p. 192).

É a primeira vez que o aspecto intelectual de Eça é mais valorizado que seu caráter de grande estilista da língua.

\section{A recepção de Eça no Brasil}

A crítica queirosiana da segunda metade do século XX é marcada pela rejeição dos discursos críticos reducionistas da crítica seminal e encontra, especialmente, na relação entre Eça e o Brasil, o foco de análise. Dentro desse cenário, encontram-se Paulo Cavalcanti com o livro Eça de Queiroz agitador no Brasil (1959), Heitor Lyra com o livro O Brasil na vida de Eça de Queirós (1965) e Arnaldo Faro com a obra Eça e o Brasil (1977). Enquanto o primeiro faz um percurso regional pela recepção de Eça no país; o segundo faz um percurso horizontal (Reis, 2000) a respeito dos acontecimentos relativos à biografia queirosiana envolvendo o Brasil; e o terceiro faz um levantamento de elementos documentais no âmbito internacional entre Eça e o Brasil.

Em seu estudo, Paulo Cavalcanti salienta o culto a Eça no Brasil, mas a marca de seu estudo está exatamente na contramão disso, quando ele focaliza os atos de protesto e ódio que dominaram Pernambuco, por algum tempo, com relação à recepção do escritor: "Não houve, no Recife, ao tempo das Farpas, ninguém que tivesse entendido o artigo de Eça de Queirós sob aquele duplo sentido que realmente o inspirou. Todos o admitiram 
como ofensa aos brasileiros, sem maiores preâmbulos” (CAVALVANTI, 1983 [1 ${ }^{\mathrm{a}}$ ed. 1959], p. 84) ${ }^{48}$. Além disso, Cavalcanti aponta que

as Farpas de Eça sobre o brasileiro constituíram-se um extremado gravame à honra nacional. Em Pernambuco por condições especiais, despertaram os artigos uma inesperada reação popular, envolvendo todas as camadas da Província [...] (CAVALVANTI, 1983 [1ª. ed. 1959], p. 89).

Essa recepção negativa de Eça por parte dos brasileiros, de acordo com o crítico, foi gerada mediante textos do autor que eram demasiadamente satíricos referentes à passagem de D. Pedro II por Portugal e Europa. Sobre isso, Arnaldo Faro faz duas considerações, uma favorável ao estudo de Paulo Cavalcanti e outra desfavorável:

São Muitos os métodos do livro de Paulo Cavalcanti: [...] No que diz respeito ao papel que, em vários dos acontecimentos narrados, foi atribuído As Farpas e seus redatores, o livro de Paulo Cavalcanti é absolutamente pioneiro.

$[\ldots]$

[a interpretação de Cavalcanti sobre alguns textos de Eça] a nosso ver, prejudicaram certas conclusões a que chegou (FARO, 1977, p. 65-66).

De acordo com o excerto, o grande aspecto do livro de Cavalcanti é o seu pioneirismo, no que tange à visita que ele empreende aos textos de Eça nas Farpas. Até então, o que aparecia na crítica seminal a respeito dessas publicações no periódico era o fato de elas serem tomadas como um marco na carreira do autor de mudança de comportamento na escrita. Com Paulo Cavalcanti, o estudo sobre As Farpas toma fôlego: “Contamos, neste livro, como os artigos de Eça e Ramalho Ortigão, em 1872, influíram no sentido de levantar a Província de Pernambuco contra os súditos de Portugal, em protesto diante das páginas escritas sobre a viagem do Imperador Pedro II à Europa" (CAVALVANTI, 1983 [1ª . ed. 1959], p. 29). Assim, segundo Jose Rodrigues de Paiva

\footnotetext{
${ }^{48}$ Da $1^{\text {a }}$ edição de 1959 a $3^{\text {a }}$ edição de 1983, o conteúdo do livro é o mesmo. O diferencial está no "Prefácio”, cujo texto apresenta observações à respeito da recepção do próprio livro no Brasil e em Portugal.
} 
(1997), o livro de Paulo Cavalcanti é “considerado um clássico da bibliografia queirosiana produzida por estudiosos brasileiros” e acrescenta que ele teria demorado

exatos dez anos de paciente e perseverante trabalho de pesquisa por bibliotecas e arquivos, em velhos documentos oficiais, cartorários, forenses, jornalísticos, por ele lidos, selecionados, anotados, interpretados, fotografados [...] (PAIVA, 1997, p. 579 -580).

Desse modo, o brasileiro resgatou o incidente histórico-literário entre Eça e os brasileiros, afirmando que a polêmica gerou campanha nativista acontecendo em Goiânia e no Recife, naquele momento, represalhas a portugueses que viviam no Brasil, mostrando um lado sombrio da recepção do autor no país.

Alguns anos depois do estudo de Paulo Cavalcanti, Heitor Lyra desenvolve um estudo minucioso sobre a relação entre Eça e o Brasil por meio da visão que o escritor tivera da terra brasileira. Para isso, ele recorre a um biografismo exaustivo, recuperando pressupostos da crítica biográfica seminal, sobrepondo biografia e ficção: “Temos, portanto, nessa carta, que é longa e detalhada, Fradique (que no caso é o próprio Eça) vai dizer ao seu amigo Prado toda a verdade sobre o que pensa do Brasil, das coisas e dos homens do Brasil” (LYRA, 1965, p. 229).

Heitor Lyra tem por foco publicar um livro que traduza o pensamento de Eça sobre o Brasil e, usando para isso o fradiquismo, as Farpas e a biografia do autor. Assim, por meio de equívocos operatórios (Reis, 2000), Lyra toma a voz de Fradique como sendo a do próprio escritor:

Está-se a ver desde já a tese que Fradique vai defender: em vez de um Brasil genuinamente brasileiro, legitimamente brasileiro, o que ele viu em nós, o que ele sentiu e encontrou foi simplesmente um Brasil falsificado e afetado, um Brasil feito de empréstimos, moldado e copiado servilmente de figurinos europeus.

Uma lástima! Porque o que Eça queria era um Brasil "natural, espontâneo e genuíno" (LYRA, 1965, p.230). 
O problema está na forma como Heitor Lyra interpreta o retrato que Fradique fizera do Brasil, tomando-o como a opinião do próprio Eça. Mais polêmico ainda é o julgamento preconceituoso a respeito do brasileiro que surge a partir da fala de Fradique e que Lyra entende como a do próprio autor.

Quanto a achar que o Brasil de 1888 era uma cópia da Europa, ou melhor, da França, essa, sim, devia ser uma ideia sobretudo sua. [...] Eça achava que o Brasil devia ser "genuíno, nacional, brasileiro"; que não fosse feito com pedaços da Europa. Muito bem. Que fosse feito, então, com quê? E de quê? Não havia de ser pedaços da África ou da Ásia! Sim, porque, fora daí, só importando a civilização da... Lua (LYRA, 1965, p.235).

Desse modo, Heitor Lyra se utiliza da carta de Fradique Mendes a Eduardo Prado equivocadamente para ilustrar a relação de Eça com o Brasil. Segundo Carlos Reis, Lyra não poderia ter esquecido que, mesmo Fradique tendo conhecimento do pensamento de Eça, o personagem tem autonomia e um “estatuto constitucional” (Reis, 2000, p.35) que dá a sua configuração.

O grande destaque no livro de Heitor Lyra é o capítulo que trata da popularidade do escritor português do Brasil, onde traz um panorama geral da recepção de Eça pelos leitores de todo o país:

Era uma popularidade que não se limitava apenas às grandes cidades brasileiras - São Paulo, Rio de Janeiro, Salvador e Recife -, mas se estendia por todo o Brasil alcançando os mais remotos recantos do território nacional (LYRA, 1965, p.444).

Para ilustrar isso, retorna aos queirosianos da primeira metade do século XX, mas inovando ao acrescentar novas fontes e fotografias cedidas pela filha de Eça, Maria de Eça de Queirós, que estão distribuídas por todo o livro. Além disso, nessa parte do estudo, monta um quadro-síntese que retrata a recepção positiva do autor no país por meio de publicações, comentários de críticos, literatos e do público em geral do século XIX, 
discorrendo acerca da "influência” que Eça tivera na forma de instrumentalizar a língua portuguesa, na forma de trajar e na produção literária dos brasileiros.

Mesmo podendo ser considerada uma releitura da crítica seminal, Heitor Lyra inova ao traçar um plano completo da relação entre Eça e o Brasil com a apresentação de cartas inéditas escritas por brasileiros para o autor e para a esposa dele, D. Emília Eça de Queirós. Outro documento importante que Heitor Lyra traz no livro é o "Prefácio" escrito pela filha:

Admiro como de pequenos detalhes soube o Sr. Heitor Lyra fazer ressuscitar o passado, e com que carinho, arte e simplicidade o apresenta! Ele quis mostrar Eça de Queirós e o Brasil, e realmente era de Brasileiros que estávamos rodeados e com quem convivíamos. É, até, curioso notar a atração que parece existir entre o Brasil e a nossa família! (apud LYRA, 1965, p.08).

O que mais chama a atenção nessa afirmação de Maria de Eça de Queirós é sua aceitação do estudo de Heitor Lyra, contrastando com a crítica ferrenha que fizera ao livro do seu compatriota João Gaspar Simões ${ }^{49}$. Observe que ela valoriza o livro do brasileiro pelo fato de ele, ao mesmo tempo, que soube levantar "problemas" na vida e na obra de Eça, também “soube compreender e perdoar” as “arremetidas ferozmente risonhas das Farpas” que criaram polêmica no país (apud LYRA, 1965, p.12).

Na década de 1970, em um percurso mais fundamentado, Arnaldo Faro publica um texto que se encaixa dentro de uma tradição historiográfica já sedimentada de se pensar a presença de Eça no Brasil. Mantém, dessa forma, uma tradição da crítica queirosiana brasileira, porém inova quando traz para a sua leitura crítica registros importantes a respeito de Eça e de sua recepção em terras brasileiras.

\footnotetext{
49 O livro Eça de Queiroz, o homem e o artista (1945), de João Gaspar Simões, não fora bem aceito pela família de Eça, especialmente, pela filha, que considerara o estudo crítico de Simões prejudicial à imagem do pai. Mesmo assim, Simões manteve o texto em edições posteriores, afirmando que nada mudaria a sua opinião sobre a vida e a obra do autor.
} 
Arnaldo Faro coloca o tom do "brasileiro e carioca” para mostrar a ligação entre Eça e o Brasil, especialmente o Rio de Janeiro.

\begin{abstract}
A admiração não desapareceu com o tempo. O leitor de alguns livros se tornou leitor de toda obra. Passou a colecionador não só do que Eça escreveu, como do que se escreveu sobre ele. Ao correr da leitura, anotações se foram acumulando. E, como o leitor é brasileiro e carioca, as notas se encontraram, de preferência, orientando quanto às ligações da vida e da obra de Eça com o Brasil e o Rio de Janeiro (FARO, 1977, s.p.).
\end{abstract}

A fim de dar início a sua trajetória, Arnaldo Faro encontra um eixo familiar entre Eça e o Brasil para fortalecer os laços entre os dois. Para isso, ele retoma a influência do Brasil na vida do escritor desde o avô de Eça, Joaquim José de Queirós, na magistratura brasileira, passando pelo nascimento do pai dele, José Maria de Almeida Teixeira de Queiroz, no Brasil, e chegando a sua ama, Ana Joaquina Leal de Barros, que era brasileira. Arnaldo Faro realiza uma breve apresentação biográfica de Eça, não se prolongando como Heitor Lyra, até atingir o momento da recepção de As Farpas em Pernambuco, fato que já tinha recebido atenção de Paulo Cavalcanti, mas que ele desenvolve de outra forma quando discorda da afirmação de que Eça teria satirizado o brasileiro nativo, quando considera que o escritor visava o português "torna-viagem", conhecido como “o brasileiro” n’ As Farpas.

Mas o que resultou, para Eça de Queirós, segundo tais conclusões, foi o seguinte quadro: teria zombado cruelmente do imperador; teria dito, dos brasileiros do Brasil (e não dos "brasileiros", isto é, portugueses que voltavam a Portugal depois de enriquecidos no Brasil) entre outras coisas menos lisonjeiras, que eram geralmente maridos enganados; mais tarde, ao publicar esse artigo em volume, o teria deliberadamente alterado, de modo a lhe modificar o alvo, que passou a ser o "brasileiro", isto é, o português "torna-viagem"; teria sido Eça, por fim, e não Ramalho, o autor da "Carta ao presidente da Província de Pernambuco", carta de tom inegavelmente áspero, aparecida no fascículo de julhoagosto, 1872, de As Farpas, e que Eça teria deixado, intencionalmente, de incluir em Uma campanha alegre (FARO, 1977, p.66). 
Em seguida, Arnaldo Faro parte para o relato sobre a publicação da primeira versão de O Crime do Padre Amaro na imprensa periódica de São Paulo, especificamente na revista A República das Letras, especializada em assuntos literários e artísticos. Um dos romances publicados, nessa revista, seria o texto de Eça, que fora interrompido logo no início da transcrição do segundo capítulo de O Crime do Padre Amaro.

Eça de Queirós aparece na fase inicial, no n. ${ }^{\circ 3}$, ou seja, no de 22 de abril de 1876. Nele, sem qualquer palavra de introdução, se principiou a publicar $O$ crime do Padre Amaro, segunda a versão divulgada pela Revista Ocidental. O romance continuou nos n. ${ }^{0 s} 4$ e 5 . Não prosseguiu, porém, na 2. ${ }^{a}$ fase, o que é compreensível, face ao lapso de tempo decorrido. Também não prosseguiu a Flor de couve. O trecho do Padre Amaro publicado naqueles três números foi bastante curto. Dos 22 capítulos de que então se compunha o romance, apenas houve a transcrição do primeiro e de quase todo o segundo (FARO, 1977, p. 105).

De forma mais detalhada, Faro comenta a recepção de $O$ Primo Basílio no Rio de Janeiro, especificamente na Rua do Ouvidor. O brasileiro faz um panorama histórico da cidade carioca, exibindo dados estatísticos, personalidades históricas e artísticas e acontecimentos da época para ilustrar o cenário de recepção da obra do escritor português. Na chegada ao Brasil, O Primo Basílio não passara despercebido e a repercussão fora tanta que resolveram adaptar o romance para o teatro, fato, então, inédito na obra de Eça e que se concretizara pela primeira vez no Rio.

Celebrado por uns, até o delírio, como superobra-prima; repelido, por outros, como o máximo de abjeção; alvo de polêmica; motivo de pancada; objeto de edição clandestina -, só faltava, para completar a consagração do Primo Basílio, que ele fosse levado ao palco. Mas também isso aconteceu, e aconteceu em duas peças, ainda em 1878 e ainda no Rio de Janeiro (FARO, 1977, p. 145). 
A partir desse momento, repleto de contrafações aos textos de Eça, Arnaldo Faro apresenta a corrida dos editores para conquistar o público brasileiro, dando início a um grande movimento editorial em torno das publicações dos textos do escritor português motivado, exatamente, pela polêmica causada na recepção de Eça no Brasil: “Assim, portanto, em 1878, quando o êxito do Primo Basílio firma de modo definitivo a reputação literária do seu autor, este podia ser lido muito mais facilmente no Brasil do que em Portugal” (FARO, 1977, p. 186).

O estudo de Arnaldo Faro, portanto, percorre a recepção de Eça no Brasil e constata um verdadeiro culto ao escritor português, alinhando-se àqueles que já tinham trabalhado outros aspectos dessa relação entre o escritor e a nação brasileira.

\section{As visões contemporâneas sobre Eça}

Mais recentemente, destacam-se, nos estudos queirosianos brasileiros, dois grandes nomes: Elza Miné e Beatriz Berrini ${ }^{50}$. Ambas marcaram presença na pesquisa sobre Eça tanto, nos trabalhos acadêmicos, quanto na crítica literária não-acadêmica. Produziram leituras a partir da década de 1970, mas atingiram consagração na década de 1980.

Elza Miné foi a pioneira a publicar uma tese acadêmica sobre Eça no país, oriunda de seu doutoramento em 1970, intitulado Crônicas de Londres e as Cartas de Inglaterra em Eça de Queiroz: uma visão crítica da Inglaterra vitoriana. Além disso, publicou até 2000 três volumes, sendo dois deles a respeito do jornalismo do escritor, denominados Eça de Queirós, jornalista (1986) e Páginas flutuantes: Eça de Queirós e o jornalismo no século XIX (2000); e uma publicação, no caso, coletiva, organizado por ela na comemoração dos 150 anos do nascimento de Eça intitulada Anais do III Encontro

\footnotetext{
${ }^{50}$ Com relação ao estudo sobre Eça de Queirós empreendido por elas, centra-se nas publicações realizadas no
} Brasil. 
Internacional de Queirosianos: 150 anos com Eça de Queirós (1997). Tem ainda diversos artigos publicados em periódicos, tanto no Brasil quanto no exterior e uma significativa contribuição para a publicação da edição crítica das obras de Eça, coordenada por Carlos Reis, da Universidade de Coimbra.

Conhecida como a especialista na obra jornalística de Eça, acredita na importância dessas publicações para compreensão da obra do autor como um todo.

Acredito que, tal como ocorre como Balzac e um Zola, com um José de Alencar e um Machado de Assis, os textos queirosianos decorrentes do exercício do jornalismo não são meramente laterais ou subsidiários [...] Não há dúvida de que a elaboração da obra ficcional foi a grande preocupação do escritor. Mas não há dúvida, também, de que os textos canonicamente de imprensa revelam, assim com os de ficção, sensível eficácia literária (MINÉ, 2000, p. 9-10).

Desse modo, Elza Miné se dedica quase que exclusivamente à análise da produção jornalística de Eça demonstrando a relevância dessa produção também para a ficção do escritor. Para ela, a produção jornalística acompanhou toda a vida de Eça, contribuindo para a formação do romancista, sendo um exemplo paradigmático da imprensa periódica de seu momento. Elza Miné acrescenta que o jornalismo do escritor português representa a própria evolução dos meios de comunicação oitocentistas.

A pesquisadora revela grande preocupação com as publicações de Eça no periódico dito brasileiro, entre 1880 e 1897, fazendo todo um levantamento cronológico desses textos. Dá ênfase à função de correspondente da Gazeta de Notícias do Rio de Janeiro que o autor exercera durante esse período e seu árduo trabalho de tentar relacionar o cotidiano sócio-político europeu com a realidade brasileira: “Eça, correspondente de um jornal brasileiro, não poderia nunca estabelecer maiores aproximações, ou apontar para diferenças, com a nossa realidade que nunca conheceu bem” (MINÉ, 2000, p. 20). 
Apesar disso, Miné aponta para a atualidade das colaborações de Eça na Gazeta de Notícias, afirmando que a resistência delas através do tempo decorre de sua aproximação com o texto literário. Considera que a obra jornalística do autor também deve ser pensada no domínio literário e não somente ideológico:

Se, na segunda metade do século XIX, colaborar em jornais e revistas acabou por constituir-se, para tantos escritores, além de elo direto com seu público, suplemento orçamentário indiscutível, e se também nesse tempo a versatilidade era a qualidade que, por excelência, caracterizava o jornalista completo, não estranha que o jornal se constituísse num laboratório privilegiado da palavra, e que a produção dessa espécie de jornalista que foi Eça de Queirós se inclua, de fato e de direito, no domínio do literário (MINÉ, 2000, p. 49).

Para ela, a produção jornalística de Eça focaliza o seu presente, historicamente, situado, mas se projetando para o futuro. Para ela, o fato de Eça dominar as funções específicas do jornalismo e da linguagem também contribuiu para esse caráter perene dos textos jornalísticos:

O trabalho do signo verbal, permitindo que hoje se leiam, nesses textos queirosianos de ontem, sentidos produzidos pela própria composição, é que fundamentalmente garante a sua serenidade e nos instiga a revisitações, a encontros novos (MINÉ, 2000, p. 76).

Defendendo a atemporalidade da produção jornalística de Eça, Elza Miné considera que, quando o texto jornalístico assume uma consistência literária, os traços da época se perdem abrindo espaço para a continuidade (podendo ser lidos em diferentes momentos históricos).

Dentro desse cenário, a estudiosa brasileira propõe que Eça desenvolvera um “projeto queirosiano para o Brasil” quando publicara no "Suplemento Literário” da Gazeta 
de Notícias, publicações que foram interrompidas precocemente e o projeto não fora concluído.

Em suma, Elza Miné exalta a posição de Eça como jornalista, pois afirma que o autor português fizera "todo um programa de ação pela palavra, toda uma concepção de funcionalidade primordial e intrínseca da imprensa, enquanto técnica de representação do mundo e forma de o entender” (MINÉ, 2000, p. 79).

A outra renomada queirosiana, Beatriz Berrini, também teve sua participação inicial nos estudos queirosianos com a sua tese de doutorado intitulada Portugal de Eça de Queiroz, de 1982, e a partir desse momento desenvolveu uma crítica sociológica em livros subsequentes como: O mundo de Eça de Queiroz (1985); dois livros de recorte temático intitulados Eça de Queiroz: Palavra e Imagem (1988) e Eça de Queiroz: literatura e arte uma antologia (2000); e uma obra coletiva organizada por ela com o título Eça de Queiroz: A Ilustra Casa de Ramires - cem anos (2000). Também escreveu o prefácio e fez a organização da edição da Obra Completa de Eça de Queirós pela Editora Aguilar do Rio de Janeiro, além de ter publicado diversos artigos sobre o escritor no Brasil e no exterior.

A estudiosa destaca-se pela análise sobre os prefácios escritos por Eça (1997), pela análise de A Ilustre Casa de Ramires (2000) e, principalmente, por estudos que retomam a época do escritor por meio da relação entre palavras e imagens. Essa última tendência crítica de Beatriz Berrini assume papel significativo dentro de suas leituras sobre Eça, na qual objetiva aproximar o universo ficcional do escritor com a realidade de sua época a partir da conjunção entre texto e contexto e texto e imagem.

Em uma perspectiva da crítica sociológica, Berrini contempla a obra queirosiana como resultado de uma criação que partira de um contexto determinado pela língua, pelo país e pela época em que fora produzida. Por exemplo, ao analisar a Ilustre Casa, ela afirma: 
Vou portanto tentar mostrar alguns aspectos do romance, procurando melhor compreender a sua organização íntima, que conduz personagens e fatos ao fim almejados. Pertencem os Ramires a uma raça ilustre, de que a sua casa em especial a antiquíssima e dificílima Torre, constituem o símbolo. Tentaremos mostrar em que medida a personagem espelha a situação da nobreza e a evolução da sociedade portuguesa, sobretudo ao retratar o decadente oitocentismo (BERRINI, 2000, p. 29).

Nesse trecho, observa-se que Beatriz Berrini privilegia a questão estética e literária antes de mostrar os elementos sociais que aparecem na estrutura narrativa. Também sobre isso, ela afirma que

Eça de Queirós, até o fim, não se separou da arte de combate [...] continuou fiel à tarefa que se tinha imposto, de mostrar aos compatriotas, como num espelho, a sociedade portuguesa contemporânea: nas vilezas do presente e no seu passado glorioso, que entretanto deveria ser avaliado com espírito crítico isento. Assim entendia ele o amor da pátria (BERRINI, 2000, p. 54-55).

Defende o caráter especular da obra de Eça devido ao movimento de espelhamento entre os textos queirosianos e a época descrita. Para ilustrar essa característica do autor português, a estudiosa faz um paralelo entre palavra e imagem que aparece, especialmente, no livro O mundo de Eça de Queiroz (1985), em que aproxima a literatura da fotografia.

Beatriz Berrini enfatiza a linguagem visualista que Eça desenvolvera nas narrativas, pois é por meio dela que a brasileira nota que o autor conduziria o leitor por um plano imaginário. Para ela, o poder verbo-visual de Eça é o aspecto que aparece predominantemente na obra do autor, já que o considera infalível observador da sociedade portuguesa de seu tempo e produtor de romances “desenháveis”.

Em uma produção crítica marcada pelas correntes sociológica, Beatriz Berrini traz uma leitura da obra queirosiana inovadora, guiando o leitor de Eça para uma leitura mais profunda dos textos do realista. 


\section{CONSIDERAÇÕES FINAIS}

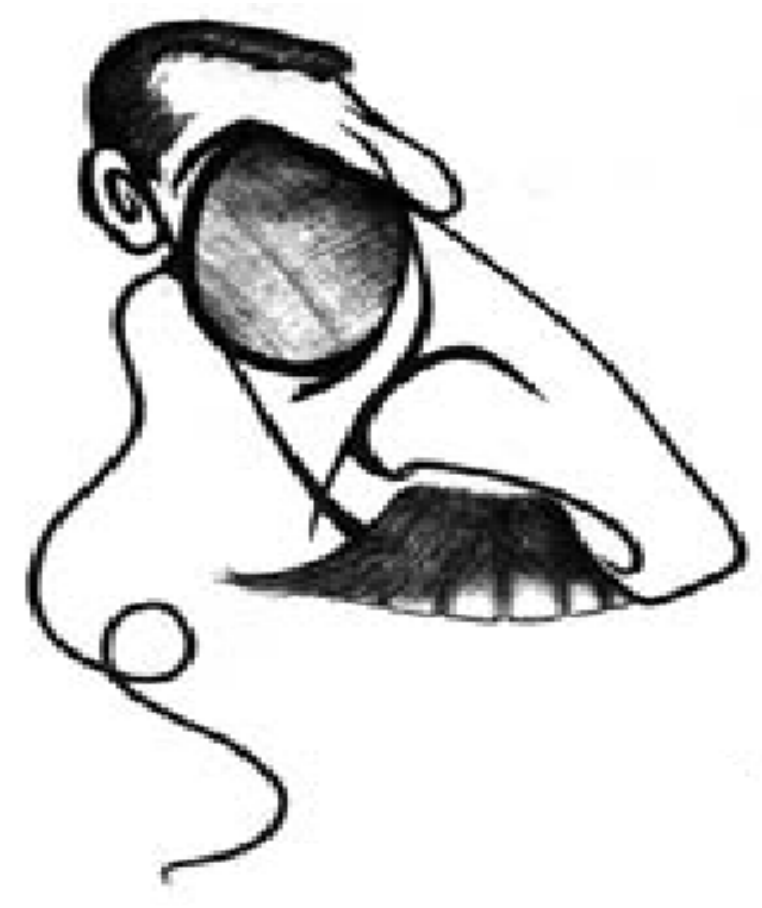

Um clássico é um livro que nunca acabou de dizer o que tem a dizer.

Ítalo Calvino 
O papel da crítica é fazer falar o texto literário, visando encontrar as muitas e por vezes contraditórias verdades que emanam das palavras. Assim, foi o papel da crítica queirosiana no Brasil durante o século XX, elucidando, na hoje já clássica obra de Eça de Queirós, sentidos que um leitor comum não encontraria.

As vozes dos queirosianos que povoaram este estudo revelam a herança literária que o escritor português deixou no Brasil desde seu tempo até os dias de hoje.

Os estudiosos se debruçaram sobre a vida e a obra de Eça por meio de diversos olhares - ora de admiração, ora analítico-investigativo, ora descritivo, ora desconfiado assumindo diferentes perspectivas críticas face ao texto do escritor. Essas diversas leituras se cruzam, complementando-se, mas também entram em conflito e se tangenciam. Porém, o que elas têm em comum é a legitimação da obra de Eça no Brasil.

Ao fazer o percurso por grande parte da crítica canônica brasileira, constata-se que a crítica seminal norteou as tendências e procedimentos da crítica queirosiana brasileira durante quase a totalidade do século $\mathrm{XX}$, cumprindo um importante papel de divulgar informações relevantes e inéditas acerca da vida e da obra do escritor. Revisitada diversas vezes por estudiosos da segunda metade do século, funcionou como um porto seguro para todos aqueles que pretendiam trabalhar com a figura do escritor.

Essa crítica pioneira apresenta quatro perspectivas dominantes: uma perspectiva formalista; uma perspectiva impressionista; uma perspectiva biográfica; uma perspectiva sócio-histórica.

Na perspectiva formal, temos Machado de Assis como único representante, que trata da obra de Eça a partir da técnica de se produzir personagens e tramas, ainda que também trate da questão do decoro e de correntes literárias.

A respeito da abordagem impressionista, revela-se um tipo de apreciação que se difunde por quase todos os críticos do período, ainda que outros tenham o foco na biografia 
ou no contexto social do escritor. Poderíamos eleger a obra de Miguel Mello, no entanto, como a que melhor representa tal perspectiva, pois é o crítico que mais faz juízos de valor subjetivos sobre a obra queirosiana. Tal abordagem valoriza as sensações que os textos queirosianos despertam naquele nos leitores, o que, se por um lado, não apresenta qualquer rigor crítico, por outro, chamou naquela altura a atenção para alguns aspectos da obra queirosiana que foram tratados posteriormente pela crítica especializada, como, por exemplo, o estilo fluido, o peso da crítica social contido na obra, a divisão desta em dois momentos distintos.

Com relação à perspectiva biográfica, ela é a grande marca da crítica seminal. Buscando na vida do autor explicações para a obra, todos (com exceção de Machado) procuraram a gênese e o sentido dos textos literários em elementos que lhe eram extrínsecos. Valendo-se das palavras de Carlos Reis, essa postura crítica centra-se no princípio “de que a um certo temperamento corresponderia forçosamente uma determinada obra” (REIS, 1981, p. 64) e foi, seguindo essa ideia, que essa abordagem da crítica seminal inaugurou a leitura da produção escrita do autor embasada na biografia.

Ao seguir por esse viés crítico, esse primeiro momento da crítica sobre Eça deu início à construção da imagem do autor no Brasil, estabelecendo como verdade o retrato do aventureiro e do artista talentoso, que conquistou o público brasileiro, dando início a um verdadeiro culto ao escritor.

A aproximação entre vida e obra possibilitou que o leitor brasileiro frequentasse a intimidade de Eça de Queirós. Cultivando os aspectos artísticos e, sobretudo, pessoais do percurso do escritor (seu nascimento, suas relações de parentesco, suas amizades, suas inimizades, sua posição social e econômica, sua carreira literária), foi possível levar os brasileiros a se imaginarem praticamente dentro da vida e da alma do autor. 
Essa perspectiva crítica dominou, sobretudo, os estudos de Miguel Mello e de Viana Moog, que cederam espaço em seus livros especificamente para relatar a vida do autor, assim como também José de Melo Jorge, que parecia abandonar o biografismo para centrar-se na análise tipológica, mas acaba estabelecendo relações bastante arbitrárias e categóricas entre os tipos queirosianos e a vida do escritor. Álvaro Lins e Clóvis Ramalhete também tentaram centrar-se na leitura da obra, mas, mesmo assim, dali também passaram de modo pouco rigoroso a estabelecer vínculos entre esta e a vida do autor; verdade que em menor grau, se comparados aos outros dois.

Foi mediante esses textos que predominou uma imagem do escritor no Brasil calcada em sua biografia. Quando Viana Moog e Melo Jorge afirmam, por exemplo, que personagens como João da Ega e Fradique Mendes são o próprio escritor, assim como levantam a possibilidade de outros personagens terem sidos criados a partir de amigos ou inimigos de Eça, induzem uma leitura da obra totalmente atrelada à biografia do escritor, fazendo com que o leitor brasileiro procure no emaranhado de personagens e citações presentes nos textos queirosianos uma hipotética verdade de fundamentação biográfica.

A abordagem biográfica também propiciou especulações acerca da psicologia de Eça, gerando internamente uma perspectiva mais específica que poderíamos designar de psicobiografia. Assim, parte dos textos fundadores passou a procurar na obra de Eça os possíveis traumas psíquicos do autor, dando especial destaque para a infância conturbada do escritor, procurando aí a chave de leitura para sua vida e sua obra. Resultaria daí um Eça de Queirós fundamentado no que se entende ser seu perfil psicológico. Quando Moog e Melo Jorge afirmam que determinados personagens ou determinados romances representam aspectos psicológicos do autor, acabam por descrevê-lo como se faz com um personagem literário, valendo aí menos sua obra que sua suposta psicologia. 
Ainda com relação à formação do autor, a crítica seminal promoveu alguns momentos da vida do autor como "rituais de passagem”: a ida de Eça à Coimbra; a viagem ao Oriente; a participação do Cenáculo, das Tertúlias e das Farpas; o casamento com D. Emília de Castro. Esses eventos foram considerados pelos textos fundadores importantes no processo de construção pessoal e profissional do autor que o levaria ser o grande artista. Tais momentos reaparecerão sistematicamente nos críticos posteriores, muitas vezes marcados por esse aspecto ritualístico.

Outra preocupação da crítica seminal foi verificar como o escritor dialogou com o contexto histórico de seu país. Trata-se de uma abordagem sócio-histórica, que defende a concepção de que a obra literária se integra num contexto ideológico e social. Embora os textos fundadores comentem a preocupação de Eça com a realidade de Portugal de sua época, não o consideram como capaz de fazer uma análise conjuntural consistente dessa realidade. Delineiam uma imagem do escritor mais como a de um dândi talentoso, que sabe fazer grandes provocações ao modo de vida português, mas não como um crítico fundamentado da realidade nacional. Essa imagem de Eça se afirma e se destaca na crítica seminal, concebendo-o sempre como um grande artista, porém jamais como um grande crítico social.

Quando ao aspecto intertextual da obra de Eça, a crítica seminal estabelece relações da obra do escritor com a de muitos outros. Desde Machado de Assis, que sugere o plágio de Zola, os críticos irão evocar Heine, Hoffman, Goethe, Shakespeare, Nerval, Michelet, Gautier, Musset, Hugo, Renan, Dickens, Poe, Baudelaire e Flaubert. Porém, diferentemente de Machado, os primeiros queirosianos brasileiros defenderam a originalidade do autor, ressaltando que ele não teria escrito textos como uma imitação de outrem e sim criaria sua própria dicção literária, jamais vivendo sob a sombra de outros, destacando-se com seu estilo peculiar. Em vista disso, verificou-se que a crítica desse 
período aceitou o fato de que a obra de Eça seguira alguns modelos anteriormente prestigiados, entendidos como parâmetros de qualidade da produção literária queirosiana.

A crítica seminal iniciou outro debate significativo sobre a fragmentação ou a unificação da obra de Eça. Parte dessa crítica acredita que a produção escrita de Eça apresentava mudanças visíveis entre as primeiras publicações e as últimas, o que resultou no caráter bipartido de sua vida e obra: a "Primeira Fase", tomada como momento contestador, transformador e polêmico; a "Segunda Fase", entendida como mais pacata, amena e elitista. Essa divisão da obra queirosiana ganhou força e passou a ser tomada como modelo para manuais do Ensino Médio no Brasil, como é possível verificar no resumo abaixo de uma aula on-line de um curso pré-vestibular:

Sua obra pode ser classificada em três fases:

$1^{\text {a }}$ fase (1866 a 1875): Inicia-se com Prosas Bárbaras, passa por $O$ Mistério da Estrada de Sintra e Uma Campanha Alegre, uma coletânea de artigos que publicara em As Farpas, periódico de natureza crítica.

$2^{\mathrm{a}}$ fase (1875 a 1887): Revela um Eça envolvido com o Realismo. Aparecem aí: O Crime do Padre Amaro, O Primo Basílio, Os Maias e $O$ Mandarim.

$3^{\mathrm{a}}$ fase (após 1887): Inserem-se as obras: A Relíquia, A Ilustre Casa de Ramires, A Cidade e as Serras. É a fase da maturidade absoluta do escritor. Há, ainda, obras de edição póstuma. ${ }^{51}$

A primeira fase foi inserida posteriormente pela crítica, que passa a considerar seus primeiros textos como marcados ainda por um romantismo tardio. As outras duas ilustram o quadro que foi criado pela crítica seminal a respeito da trajetória da carreira literária de Eça, que teria começado como um escritor militante do Naturalismo e que, aos poucos, foi se deixando abater e se reconciliando com Deus, com a pátria e com a família. Assim, os textos fundadores inauguraram concepções que estão cristalizadas e são reproduzidas até hoje em dia.

\footnotetext{
${ }^{51}$ Cf. http://www.cpv.com.br/cpv_vestibulandos/dicas/livros/litobr3701.pdf
} 
Observando a trajetória da crítica queirosiana brasileira entre as efemérides (19452000), constatou-se que foi um período que reafirmou algumas diretrizes lançadas pela crítica seminal a respeito da vida e da obra do autor, mas inaugurou novos olhares sobre Eça, restituindo-lhe a imagem de intelectual, sem abandonar a defesa ao artista talentoso. Acrescentou-se a essa visão do artista um forte posicionamento crítico-social que aparece tanto na produção jornalística quanto na literária. Dessa forma, Eça passou a ser visto como um verdadeiro retratista de sua época, em razão de sua observação aguçada da realidade que lhe era coeva.

O viés sócio-histórico perdurou e aumentou seu campo de atuação. Além disso, surgiram novas abordagens para analisar a obra do escritor português como a estilística, a relação de Eça com o Brasil, a crítica textual sobre a produção jornalística, entre outras.

Em sentido amplo, portanto, a crítica queirosiana brasileira percorreu dois caminhos: um caminho circular, ecoando vozes repetidas por décadas; e um caminho que passou a ver Eça de maneira sempre inovadora. De qualquer modo, toda a produção crítica sobre Eça no Brasil tem participação incontestável na divulgação da obra queirosiana no país, podendo, como já foi dito na "Introdução" deste trabalho, ser considerada uma metonímia da crítica queirosiana mundial. 


\section{CONSIDERAÇÕES FINAIS}

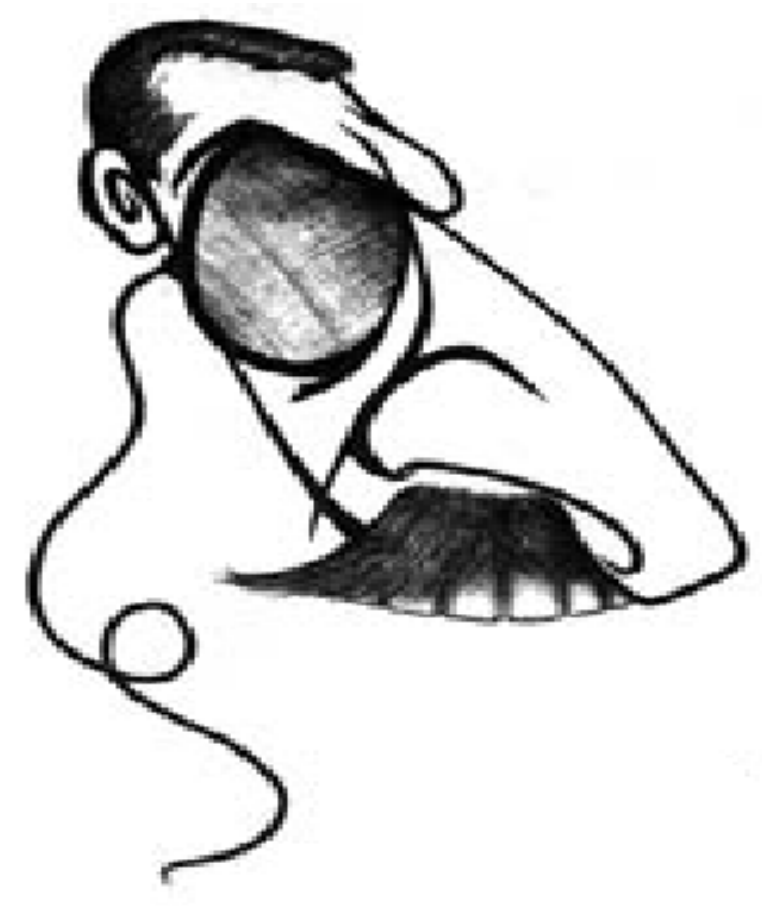

Um clássico é um livro que nunca acabou de dizer o que tem a dizer.

Ítalo Calvino 
O papel da crítica é fazer falar o texto literário, visando encontrar as muitas e por vezes contraditórias verdades que emanam das palavras. Assim, foi o papel da crítica queirosiana no Brasil durante o século XX, elucidando, na hoje já clássica obra de Eça de Queirós, sentidos que um leitor comum não encontraria.

As vozes dos queirosianos que povoaram este estudo revelam a herança literária que o escritor português deixou no Brasil desde seu tempo até os dias de hoje.

Os estudiosos se debruçaram sobre a vida e a obra de Eça por meio de diversos olhares - ora de admiração, ora analítico-investigativo, ora descritivo, ora desconfiado assumindo diferentes perspectivas críticas face ao texto do escritor. Essas diversas leituras se cruzam, complementando-se, mas também entram em conflito e se tangenciam. Porém, o que elas têm em comum é a legitimação da obra de Eça no Brasil.

Ao fazer o percurso por grande parte da crítica canônica brasileira, constata-se que a crítica seminal norteou as tendências e procedimentos da crítica queirosiana brasileira durante quase a totalidade do século $\mathrm{XX}$, cumprindo um importante papel de divulgar informações relevantes e inéditas acerca da vida e da obra do escritor. Revisitada diversas vezes por estudiosos da segunda metade do século, funcionou como um porto seguro para todos aqueles que pretendiam trabalhar com a figura do escritor.

Essa crítica pioneira apresenta quatro perspectivas dominantes: uma perspectiva formalista; uma perspectiva impressionista; uma perspectiva biográfica; uma perspectiva sócio-histórica.

Na perspectiva formal, temos Machado de Assis como único representante, que trata da obra de Eça a partir da técnica de se produzir personagens e tramas, ainda que também trate da questão do decoro e de correntes literárias.

A respeito da abordagem impressionista, revela-se um tipo de apreciação que se difunde por quase todos os críticos do período, ainda que outros tenham o foco na biografia 
ou no contexto social do escritor. Poderíamos eleger a obra de Miguel Mello, no entanto, como a que melhor representa tal perspectiva, pois é o crítico que mais faz juízos de valor subjetivos sobre a obra queirosiana. Tal abordagem valoriza as sensações que os textos queirosianos despertam naquele nos leitores, o que, se por um lado, não apresenta qualquer rigor crítico, por outro, chamou naquela altura a atenção para alguns aspectos da obra queirosiana que foram tratados posteriormente pela crítica especializada, como, por exemplo, o estilo fluido, o peso da crítica social contido na obra, a divisão desta em dois momentos distintos.

Com relação à perspectiva biográfica, ela é a grande marca da crítica seminal. Buscando na vida do autor explicações para a obra, todos (com exceção de Machado) procuraram a gênese e o sentido dos textos literários em elementos que lhe eram extrínsecos. Valendo-se das palavras de Carlos Reis, essa postura crítica centra-se no princípio “de que a um certo temperamento corresponderia forçosamente uma determinada obra” (REIS, 1981, p. 64) e foi, seguindo essa ideia, que essa abordagem da crítica seminal inaugurou a leitura da produção escrita do autor embasada na biografia.

Ao seguir por esse viés crítico, esse primeiro momento da crítica sobre Eça deu início à construção da imagem do autor no Brasil, estabelecendo como verdade o retrato do aventureiro e do artista talentoso, que conquistou o público brasileiro, dando início a um verdadeiro culto ao escritor.

A aproximação entre vida e obra possibilitou que o leitor brasileiro frequentasse a intimidade de Eça de Queirós. Cultivando os aspectos artísticos e, sobretudo, pessoais do percurso do escritor (seu nascimento, suas relações de parentesco, suas amizades, suas inimizades, sua posição social e econômica, sua carreira literária), foi possível levar os brasileiros a se imaginarem praticamente dentro da vida e da alma do autor. 
Essa perspectiva crítica dominou, sobretudo, os estudos de Miguel Mello e de Viana Moog, que cederam espaço em seus livros especificamente para relatar a vida do autor, assim como também José de Melo Jorge, que parecia abandonar o biografismo para centrar-se na análise tipológica, mas acaba estabelecendo relações bastante arbitrárias e categóricas entre os tipos queirosianos e a vida do escritor. Álvaro Lins e Clóvis Ramalhete também tentaram centrar-se na leitura da obra, mas, mesmo assim, dali também passaram de modo pouco rigoroso a estabelecer vínculos entre esta e a vida do autor; verdade que em menor grau, se comparados aos outros dois.

Foi mediante esses textos que predominou uma imagem do escritor no Brasil calcada em sua biografia. Quando Viana Moog e Melo Jorge afirmam, por exemplo, que personagens como João da Ega e Fradique Mendes são o próprio escritor, assim como levantam a possibilidade de outros personagens terem sidos criados a partir de amigos ou inimigos de Eça, induzem uma leitura da obra totalmente atrelada à biografia do escritor, fazendo com que o leitor brasileiro procure no emaranhado de personagens e citações presentes nos textos queirosianos uma hipotética verdade de fundamentação biográfica.

A abordagem biográfica também propiciou especulações acerca da psicologia de Eça, gerando internamente uma perspectiva mais específica que poderíamos designar de psicobiografia. Assim, parte dos textos fundadores passou a procurar na obra de Eça os possíveis traumas psíquicos do autor, dando especial destaque para a infância conturbada do escritor, procurando aí a chave de leitura para sua vida e sua obra. Resultaria daí um Eça de Queirós fundamentado no que se entende ser seu perfil psicológico. Quando Moog e Melo Jorge afirmam que determinados personagens ou determinados romances representam aspectos psicológicos do autor, acabam por descrevê-lo como se faz com um personagem literário, valendo aí menos sua obra que sua suposta psicologia. 
Ainda com relação à formação do autor, a crítica seminal promoveu alguns momentos da vida do autor como "rituais de passagem”: a ida de Eça à Coimbra; a viagem ao Oriente; a participação do Cenáculo, das Tertúlias e das Farpas; o casamento com D. Emília de Castro. Esses eventos foram considerados pelos textos fundadores importantes no processo de construção pessoal e profissional do autor que o levaria ser o grande artista. Tais momentos reaparecerão sistematicamente nos críticos posteriores, muitas vezes marcados por esse aspecto ritualístico.

Outra preocupação da crítica seminal foi verificar como o escritor dialogou com o contexto histórico de seu país. Trata-se de uma abordagem sócio-histórica, que defende a concepção de que a obra literária se integra num contexto ideológico e social. Embora os textos fundadores comentem a preocupação de Eça com a realidade de Portugal de sua época, não o consideram como capaz de fazer uma análise conjuntural consistente dessa realidade. Delineiam uma imagem do escritor mais como a de um dândi talentoso, que sabe fazer grandes provocações ao modo de vida português, mas não como um crítico fundamentado da realidade nacional. Essa imagem de Eça se afirma e se destaca na crítica seminal, concebendo-o sempre como um grande artista, porém jamais como um grande crítico social.

Quando ao aspecto intertextual da obra de Eça, a crítica seminal estabelece relações da obra do escritor com a de muitos outros. Desde Machado de Assis, que sugere o plágio de Zola, os críticos irão evocar Heine, Hoffman, Goethe, Shakespeare, Nerval, Michelet, Gautier, Musset, Hugo, Renan, Dickens, Poe, Baudelaire e Flaubert. Porém, diferentemente de Machado, os primeiros queirosianos brasileiros defenderam a originalidade do autor, ressaltando que ele não teria escrito textos como uma imitação de outrem e sim criaria sua própria dicção literária, jamais vivendo sob a sombra de outros, destacando-se com seu estilo peculiar. Em vista disso, verificou-se que a crítica desse 
período aceitou o fato de que a obra de Eça seguira alguns modelos anteriormente prestigiados, entendidos como parâmetros de qualidade da produção literária queirosiana.

A crítica seminal iniciou outro debate significativo sobre a fragmentação ou a unificação da obra de Eça. Parte dessa crítica acredita que a produção escrita de Eça apresentava mudanças visíveis entre as primeiras publicações e as últimas, o que resultou no caráter bipartido de sua vida e obra: a "Primeira Fase", tomada como momento contestador, transformador e polêmico; a "Segunda Fase", entendida como mais pacata, amena e elitista. Essa divisão da obra queirosiana ganhou força e passou a ser tomada como modelo para manuais do Ensino Médio no Brasil, como é possível verificar no resumo abaixo de uma aula on-line de um curso pré-vestibular:

Sua obra pode ser classificada em três fases:

$1^{\text {a }}$ fase (1866 a 1875): Inicia-se com Prosas Bárbaras, passa por $O$ Mistério da Estrada de Sintra e Uma Campanha Alegre, uma coletânea de artigos que publicara em As Farpas, periódico de natureza crítica.

$2^{\mathrm{a}}$ fase (1875 a 1887): Revela um Eça envolvido com o Realismo. Aparecem aí: O Crime do Padre Amaro, O Primo Basílio, Os Maias e $O$ Mandarim.

$3^{\mathrm{a}}$ fase (após 1887): Inserem-se as obras: A Relíquia, A Ilustre Casa de Ramires, A Cidade e as Serras. É a fase da maturidade absoluta do escritor. Há, ainda, obras de edição póstuma. ${ }^{52}$

A primeira fase foi inserida posteriormente pela crítica, que passa a considerar seus primeiros textos como marcados ainda por um romantismo tardio. As outras duas ilustram o quadro que foi criado pela crítica seminal a respeito da trajetória da carreira literária de Eça, que teria começado como um escritor militante do Naturalismo e que, aos poucos, foi se deixando abater e se reconciliando com Deus, com a pátria e com a família. Assim, os textos fundadores inauguraram concepções que estão cristalizadas e são reproduzidas até hoje em dia.

\footnotetext{
${ }^{52}$ Cf. http://www.cpv.com.br/cpv_vestibulandos/dicas/livros/litobr3701.pdf
} 
Observando a trajetória da crítica queirosiana brasileira entre as efemérides (19452000), constatou-se que foi um período que reafirmou algumas diretrizes lançadas pela crítica seminal a respeito da vida e da obra do autor, mas inaugurou novos olhares sobre Eça, restituindo-lhe a imagem de intelectual, sem abandonar a defesa ao artista talentoso. Acrescentou-se a essa visão do artista um forte posicionamento crítico-social que aparece tanto na produção jornalística quanto na literária. Dessa forma, Eça passou a ser visto como um verdadeiro retratista de sua época, em razão de sua observação aguçada da realidade que lhe era coeva.

O viés sócio-histórico perdurou e aumentou seu campo de atuação. Além disso, surgiram novas abordagens para analisar a obra do escritor português como a estilística, a relação de Eça com o Brasil, a crítica textual sobre a produção jornalística, entre outras.

Em sentido amplo, portanto, a crítica queirosiana brasileira percorreu dois caminhos: um caminho circular, ecoando vozes repetidas por décadas; e um caminho que passou a ver Eça de maneira sempre inovadora. De qualquer modo, toda a produção crítica sobre Eça no Brasil tem participação incontestável na divulgação da obra queirosiana no país, podendo, como já foi dito na "Introdução" deste trabalho, ser considerada uma metonímia da crítica queirosiana mundial. 
BIBLIOGRAFIA 


\section{Obras de Eça de Queirós}

\subsection{Romance}

O Mistério da Estrada de Sintra. S.l.: Europa-América, 2000. [1871]

O Crime do Padre Amaro. 15. ed. São Paulo: Ática, 2004. [1876]

O Primo Basílio. 22. ed. São Paulo: Ática, 2002. [1878]

O Mandarim. São Paulo: Martin Claret, 2004. [1879]

A Relíquia. Rio de Janeiro: Ediouro, 1997. [1887]

Os Maias. 6. ed. Rio de Janeiro: Ediouro, 2004. [1888]

A Correspondência de Fradique Mendes: memórias e notas. 2. ed. Porto: Lello \& Irmão, 1944. [1900]

A Ilustre Casa de Ramires. São Paulo: Abril, 2003. [1900]

A Cidade e as Serras. São Paulo: Princípio, 1994. [1901]

A Capital. Rio de Janeiro: Edições de Ouro, 1971. [1925]

O Conde d’Abranhos. Lisboa: Livros do Brasil, s.d. [1925]

Alves e Cia. 4. ed. São Paulo: Ática, 2001. [1925]

A Tragédia das Ruas das Flores. Lisboa: Moraes Editores, 1980. [1980]

\subsection{Conto}

Contos. Lisboa: Livros do Brasil, s.d. [1902]

\subsection{Jornalismo e Hagiografia}

Uma campanha alegre. Porto: Lello \& Irmão, 1980. [1890-1891]

Prosas bárbaras. São Paulo: Lello Brasileira, 1970. [1903]

Cartas de Inglaterra. Porto: Lello \& Irmão, 1951. [1905]

Ecos de Paris. Porto: Lello \& Irmão, 1944. [1905] 
Cartas familiares e bilhetes de Paris. Porto: Lello \& Irmão, s.d. [1907]

Notas contemporâneas. 4. ed. Porto: Chardron, 1923. [1909]

Últimas páginas. São Paulo: Brasiliense, 1961. [1912]

O Egito. Porto: Lello \& Irmão, 1946. [1926]

Cartas inéditas de Fradique Mendes e mais Páginas Esquecidas. Porto: Chardron, 1929. [1929]

Cartas de Londres. 4. ed. Lisboa: Círculo de Leitores, 1982. [1944]

Cartas de Lisboa. Lisboa: Círculo de Leitores, 1982. [1944]

\subsection{Correspondência}

Correspondência. Porto: Lello \& Irmão, 1925. [1925]

Cartas de Eça de Queirós. Porto: Aviz, 1945. [1945]

Eça de Queirós entre os seus: cartas íntimas. 6. ed. Porto: Lello \& Irmão, 1987. [1948]

\section{Fortuna crítica sobre Eça de Queirós}

ABDALA JÚNIOR, Benjamin. Eça de Queirós. São Paulo: Abril Educação, 1980. (org.). Ecos do Brasil: Eça de Queirós, leituras brasileiras e portuguesas. São Paulo: SENAC, 2000.

. Eça de Queirós, o realismo e a circulação literária entre Portugal e Brasil. In:

(org.). Ecos do Brasil: Eça de Queirós, leituras brasileiras e portuguesas. São Paulo: SENAC, 2000, p. 89-117.

De percursos e distâncias, entre dois finais de século. In: SCARPELLI, Marli Fantini; OLIVEIRA, Paulo Motta (org.). Os centenários. Eça, Freyre, Nobre. Belo Horizonte: FALE/UFMG, 2001, p. 135-150.

. Eça de Queirós entre a observação, a experiência e a imaginação: repertório realista em trânsito. Semear. Rio de Janeiro, n. 6, p. 41-57. 2002. 
ACTAS DO CONGRESSO DE ESTUDOS QUEIROSIANOS. IV ENCONTRO INTERNACIONAL DE QUEIROSIANOS. Coimbra: Almedina, 2002. v.1 e 2.

ALMEIDA, António Ramos de. Eça. Porto: Latina, 1945.

ALMEIDA, Francisco Vieira de. A máscara de Eça. Lisboa: Romero, 1945.

ALVES, Dário Moreira de Castro. Era Lisboa e chovia. Rio de Janeiro: Nórdica, 1984. Era porto e entardecia: de absinto a zurrapa - dicionário de vinhos e bebidas alcoólicas em geral na obra de Eça de Queiroz. Rio de Janeiro: Nórdica, 1995.

AMARAL, Glória Carneiro do. O Primo Basílio n’O Besouro: um aspecto pontual da recepção do romance no Brasil. In: MINÉ, Elza. (org.). 150 anos com Eça de Queirós Anais do III Encontro Internacional de Queirosianos. São Paulo: Centro de Estudos Portugueses/FFLCH/USP, 1997, p. 212-219.

AMARAL, Vasco Botelho de. Camões \& Eça de Queirós. Belo Horizonte: Vigília, 1978. ASSIS, Machado de. Eça de Queirós: O Primo Basílio. In: __. Crítica Literária. Rio de Janeiro, São Paulo, Porto Alegre: W. M. Jackson, 1946, p. 160-186.

AYRES, Francisco. Eça de Queiroz: vida e glória. Rio de Janeiro: Nórdica, 1983.

BARBOSA, João Alexandre. Os intervalos de Eça de Queiroz. In: A biblioteca imaginária. São Paulo: Ateliê Editorial, 1996, p. 91-134.

. Uma edição crítica de Eça de Queirós. In: Entrelivros. São Paulo: Ateliê Editorial, 1999, p. 53-62.

A torre literária de Eça de Queirós. Cult. São Paulo, n. 38, p. 42-47, set. 2000.

BASTO, Cláudio. Foi Eça de Queirós um plagiador? Porto: Maranus, 1924.

BELLINE, Ana Helena Cizotto. Eça de Queirós. São Paulo: Ática, 1997.

BELLO, José Maria. As idolatrias literárias. Eça de Queirós e a sua influência no Brasil. Estudos Críticos. Rio de Janeiro: Jacintho Ribeiro dos Santos, 1917, p. 15-31. . Retrato de Eça de Queirós. Rio de Janeiro: Agir, 1945.

BERRINI, Beatriz. Portugal de Eça de Queiroz. Lisboa: Imprensa Nacional-Casa da Moeda, 1984.

. Eça de Queiroz: palavra e imagens. S.l.: Edições Inapa, 1988. 
Os prefácios ensaísticos de Eça de Queirós. In: MINÉ, Elza. (Org.). 150 anos com Eça de Queirós - Anais do III Encontro Internacional de Queirosianos. São Paulo: Centro de Estudos Portugueses/FFLCH/USP, 1997, p. 113-121.

(org., apres. e com.) Eça de Queiroz, literatura e arte - uma antologia. Lisboa: Relógio D’Água, 2000, p. 21-39.

A Ilustre Casa de Ramires - cem anos. São Paulo: Editora da PUC, FAPESP, 2000.

. O arruinado solar de uma ilustra Casa. In: BERRINI, Beatriz (org.) A Ilustre Casa de Ramires - cem anos. São Paulo: Editora da PUC, FAPESP, 2000, p. 27-55.

(org.) Relações brasileiras de Eça de Queiroz. In: Obra completa de Eça de Queiroz. Rio de Janeiro: Nova Aguilar, 2000. v. IV. . Brasil e Portugal: a geração de 70. Porto: Campo das Letras, 2003.

BOLÉO, Manuel da Paiva. O realismo de Eça de Queirós e a sua expressão artística. 2.ed. Coimbra: Coimbra Editora, 1942.

BOTICA, Cassiano Nunes. O lusitanismo de Eça de Queirós. Rio de Janeiro: Editora da Casa do Estudante do Brasil, 1947.

BROCA, Brito. A vida literária no Brasil - 1900. Rio de Janeiro: José Olympio, 1960.

CABRAL, Antonio. Eça de Queiroz: a sua vida e a sua obra. 3. ed. Lisboa: Bertrand, 1945.

CANDIDO, Antonio. Eça de Queirós: entre o campo e a cidade. In: . Tese e antítese. 4. ed. São Paulo: T. A. Queiroz, 2000, p. 29-56.

Eça de Queirós, passado e presente. In: ABDALA JÚNIOR, Benjamin (org.). Ecos do Brasil: Eça de Queirós, leituras brasileiras e portuguesas. São Paulo: SENAC, 2000, p. 11-22.

Ironia e latência. In: BERRINI, Beatriz (org.). A Ilustre Casa de Ramires - cem anos. São Paulo: Editora da PUC, FAPESP, 2000, p. 17-26.

CARVALHO Jr., Dagoberto Ferreira. Eça de Queiroz: retratos de memória. Recife: Diário de Pernambuco, 2001. 
CARVALHO, Reginaldo Pinto de. Eça de Queirós: o senhor das palavras. Anatomia das Letras. São Paulo, v. 1, p. 14-20, out. 1994.

CATTON, Albano Pereira. Eça de Queiroz: dicionário biográfico dos seus personagens. S.l.: Borsoi, 19--.

CAVALCANTI, Paulo. Eça de Queiroz agitador no Brasil. 3. ed. Recife: Guararapes, 1983.

Eça de Queirós e o Brasil. Cult. São Paulo, n. 38, p. 58-61, set. 2000.

CHAVES, Castelo Branco. Sobre Eça de Queirós. Lisboa: Inquéritos, 1937.

COELHO, Vicente de Faria. Símbolos e personagens de vanguarda. Rio de Janeiro: Almeida Marques, 1975.

COLEMAN, Alexander. Uma reflexão a respeito de Eça de Queirós e Machado de Assis. In: ACTAS DO I ENCONTRO INTERNACIONAL DE QUEIROSIANOS. Porto: Edições Asa, Faculdades de Letras da Universidade do Porto, 1988.

CORDEIRO, José Pedro Leite. Eçaiana. Cronologia das obras de Eça de Queirós. São Paulo: Empresa Editorial Universal, 1945.

CORTESÃO, Jaime. Eça de Queirós e a questão social. Lisboa: Seara Nova, 1949.

COSTA, Joaquim. Eça de Queirós, criador de realidade e inventor de fantasias. Porto: Livraria Civilização, 1945.

COSTA, Júlio de Sousa e. Eça de Queiroz. Lisboa: Livraria Sá de Costa, 1953.

CRUZ, José Marques da. Eça de Queiroz: a sua psique. São Paulo: Melhoramentos, 1949.

CUNHA, Maria do Rosário. Molduras: articulações externas do romance queirosiano. Coimbra: Universidade Aberta, 1997.

DUARTE, Lélia Parreira. Realismo e "ilusão do real”: ambiguidade e ironia em Eça de Queirós. In: SCARPELLI, Marli Fantini; OLIVEIRA, Paulo Motta (orgs.). Os centenários. Eça, Freyre, Nobre. Belo Horizonte: FALE/UFMG, 2001, p. 187-194.

DUARTE, Luiz Fagundes. Os papéis de Eça e a crítica. In: MINÉ, Elza. (org.). 150 anos com Eça de Queirós - Anais do III Encontro Internacional de Queirosianos. São Paulo: Centro de Estudos Portugueses/FFLCH/USP, 1997, p. 328-335. 
DUQUE, Gonzaga, Eça de Queiroz: a influência de sua obra na literatura brasileira. Annuário Fluminense. Rio de Janeiro, p. 6-13. 1901.

EÇA DE QUEIRÓS. DOCUMENTÁRIO DE UMA COMEMORAÇÃO. Recife: Imprensa Oficial, 1947.

FARO, Arnaldo. Eça e o Brasil. São Paulo: EDUSP, 1977.

FEITOSA, Rosane Gazolla Alves. A recepção crítica de Eça de Queirós/Fradique Mendes no Pré-Modernismo Brasileiro: Jornal Paulistano O Pirralho (1911-1917). Actas do Congresso de Estudos Queirosianos. IV Encontro Internacional de Queirosianos. Coimbra: Almedina, 2002, p. 859-867. v.2.

FERNANDES, Maria Lúcia Outeiro. O entre - lugar de Eça de Queirós na tradição realista. In: SCARPELLI, Marli Fantini; OLIVEIRA, Paulo Motta (orgs.). Os centenários. Eça, Freyre, Nobre. Belo Horizonte: FALE/UFMG, 2001, p. 229-237.

FERNANDES, Annie Gisele; OLIVEIRA, Paulo Motta (orgs.). Literatura Portuguesa: Aquém-Mar. Campinas: Editora Komedi, 2005.

FERRAZ, Paulo Malta. Viagem ao Portugal de Eça de Queirós. Rio de Janeiro: Editora Rio, 1971.

FERRO, Antonio. Eça de Queiroz e o centenário do seu nascimento. Lisboa: Edições SNI, 1949.

FIGUEIREDO, Fidelino de. Um pobre homem de Povoa de Varzim. Lisboa: Portugália, 1944.

FONSECA, Gondin da. Eça de Queiroz. Uma biografia pioneira. Rio de Janeiro: Borsoi, 1970.

A tragédia de Eça de Queirós. Sua vida e sua obra, repulsa dos pais, narcisismo, lutas, os abismos do inconsciente. Rio de Janeiro: Livraria São José, 1972.

FRANCHETTI, Paulo; Berrini, Beatriz. Correspondência: J. M. Eça de Queiroz e J. P. O. Martins. Campinas, SP: Editora Unicamp, 1995.

Eça e Machado: críticas de ultramar. Cult. São Paulo, ano IV, n. 38, p. 48-53, 2000.

Febre de Eça. Mais! Folha de São Paulo, 13 de agosto de 2000. 
O Primo Basílio. In: Estudos de literatura brasileira e portuguesa. Cotia, SP: Ateliê Editorial, 2007, p. 135-158.

. Um Patife Encantador? In: Estudos de literatura brasileira e portuguesa. Cotia, SP: Ateliê Editorial, 2007, p. 159-170.

O Primo Basílio e a Batalha do Realismo no Brasil. In: . Estudos de literatura brasileira e portuguesa. Cotia, SP: Ateliê Editorial, 2007, p. 171-192.

GARMES, Hélder. As fronteiras da civilização em Eça de Queirós. In: FERNANDES, Annie Gisele; OLIVEIRA, Paulo Motta (orgs.) Literatura Portuguesa: aquém-mar. Campinas: Komedi, 2005.

GILBERTO, Irene Jeanete Lemos. A crítica de Fidelino de Figueiredo sobre Eça de Queirós. Actas do Congresso de Estudos Queirosianos. IV Encontro Internacional de Queirosianos. Coimbra: Almedina, 2002, p. 515-522. v. 2.

GOMES, Álvaro Cardoso. Pobre Eça de Queirós. Visão. São Paulo, v. 37, n. 38, p. 52, set. 1988.

GOMES, Vânia Regina. O aprendiz de Fradique Mendes: Eça de Queirós na leitura de Gilberto Freyre. São Paulo: 2006. 157f. Dissertação (Mestrado em Estudos Comparados de Literaturas de Língua Portuguesa) - Faculdade de Filosofia, Letras e Ciências Humanas, Universidade de São Paulo, São Paulo.

GOUVEA, Fernando da Cruz. Eça de Queiroz Empreiteiro da Risada. Recife: Edições Comunicarte, 1995.

GUERRA DA CAL, Ernesto. Língua e estilo de Eça de Queiroz. 8. ed. São Paulo: EDUSP/ Rio de Janeiro: Tempo Brasileiro, 1969.

Lengua y estilo de Eça de Queiroz. Apéndice. Bibliografía Queirociana Sistemática y Anotada e Iconografía Artística del Hombre y la Obra. Tomos $1^{\circ}$ e $2^{\circ}$, Acta Universitatis Conimbrigensis, 1976.

JÚLIO, Sílvio. Projeção Universal de Eça de Queiroz. Rio de Janeiro: Livraria H. Antunes, 1943.

LIMA, Isabel Pires de (coord.). Eça e "Os Maias". Porto: Edições Asa, 1990. Retratos de Eça de Queiroz. Porto: Campo das Letras, 2000. 
LINS, Álvaro. História literária de Eça de Queiroz. Rio de Janeiro: José Olympio, 1939.

LISBOA, Maria Manuel. Machado e Eça ou a mão e a luva: tótem e não tabu. Via Atlântica. São Paulo: FFLCH/USP, n.2, p. 151-159, jul. 1999.

LONTRA, Hilda. Eça e o seu tempo: Ele e o nosso tempo. In: MINÉ, Elza (org.) 150 anos com Eça de Queirós - Anais do III Encontro Internacional de Queirosianos. São Paulo: Centro de Estudos Portugueses/FFLCH/USP, 1997, p. 553-562.

LOPES, Stenio. Roteiro de Eça de Queiroz. Ceará: Edições Clã, 1946.

LOPES, Thomaz. Eça de Queiroz. Sete Soes. Rio de Janeiro: Garnier, 1911, p. 11-19.

LUZES, Pedro. Sob o manto diáfano do Realismo: psicanálise de Eça de Queiroz. Lisboa: Fim de Século, 2001.

LYRA, Heitor. O Brasil na vida de Eça de Queirós. Lisboa: Livros do Brasil, 1965.

MAGALHÃES, José Calvet de. José Maria, a vida privada de um grande escritor. Vanda Nova: Bertrand, 1994.

MARQUES, Edgard. Interpretação espiritual de Eça de Queirós. Lisboa: Guimarães, 1946.

MARQUES, Gentil. Eça de Queirós: o romance da sua vida e da sua obra. Lisboa: Romano Torre, 1946.

MARTINS, A. Coimbra. Ensaios queirosianos. Lisboa: Publicações Europa-América, 1967.

MATOS, Alfredo Campos (dir.). Dicionário de Eça de Queiroz. 2. ed. Lisboa: Caminho, 1993.

A correspondência epistolar entre Eça de Queirós e sua mulher Emília de Castro. Algumas conjecturas de crítica biográfica a partir das cartas inéditas de Emília de Castro. In: MINÉ, Elza (org.) 150 anos com Eça de Queirós - Anais do III Encontro Internacional de Queirosianos. São Paulo: Centro de Estudos Portugueses/FFLCH/USP, 1997, p. 38-44. (dir.). Suplemento ao Dicionário de Eça de Queiroz. Lisboa: Caminho, 2000. Ilustrações e Ilustradores na obra de Eça de Queiroz. Lisboa: Livros Horizonte, 2001. 
. Sobre Eça de Queiroz. Lisboa: Livros Horizonte, 2002.

MEDINA, João. Eça de Queiroz e a geração de 70. Lisboa: Moraes Editores, 1980. . Eça político. Lisboa: Seara Nova, 1984. . Eça de Queirós antibrasileiro? Bauru, SP: EDUSC, 2000.

MELO JORGE, José de. Os tipos de Eça de Queiroz. São Paulo: Livraria Brasil, 1940.

MELLO, Allyrio de. Eça de Queiroz: o exilado da realidade. Porto: Livraria Tavares Martins, 1945.

MELLO, Miguel. Eça de Queirós. A obra e o homem. Rio de Janeiro: Livraria Italiana e Tipografia Ramori \& Cia., 1911.

MENESES, Djacir. Crítica social de Eça de Queirós. 3. ed. Rio de Janeiro: Olímpica Editora, 1970.

MIGUEL-PEREIRA, Lúcia; Câmara Reis (orgs.). Livro do Centenário de Eça de Queirós. Lisboa /Rio de Janeiro: Edições "Dois Mundos", 1945.

Machado de Assis e Eça de Queiroz. Revista de Portugal. Coimbra, 8, jul, 1939, p. $474-478$.

MINÉ, Elza. Eça de Queirós e a imprensa brasileira. Convergência Lusíada. Rio de Janeiro, s.d. p. 78-89.

Eça de Queirós, jornalista. Lisboa: Livros Horizonte, 1986.

. Posições de leitura: textos de imprensa de Eça de Queirós para a Gazeta de Notícias. São Paulo: Hvf - Arte e Cultura/ FCL-UNESP, 1994, p. 111-121.

(Org.). 150 anos com Eça de Queirós - Anais do III Encontro Internacional de Queirosianos. São Paulo: Centro de Estudos Portugueses/FFLCH/USP, 1997.

. Quando os paquetes encurtavam as distâncias. Centro de Estudos Portugueses. São Paulo: FFLCH/USP, n.1, p. 117-121. 1998.

Páginas flutuantes: Eça de Queirós e o jornalismo no século XIX. Cotia, São Paulo: Ateliê Editorial, 2000.

Eça jornalista no Brasil. In: ABDALA JÚNIOR, Benjamin (org.). Ecos do Brasil: Eça de Queirós, leituras brasileiras e portuguesas. São Paulo: SENAC, 2000, p. 39-53. 
Textos de Imprensa IV. Lisboa: Imprensa Nacional - Casa da Moeda, 2002.

A recepção de Eça de Queirós no Brasil. In: BERRINI, Beatriz (org.). Eça e Machado. São Paulo: EDUC, FAPESP, Fundação Gulbenkian, 2005, p. 213-224.

Os óculos latino-americanos e o monóculo europeu: Manuel Bandeira e Eça de Queirós. In: ABDALA JÚNIOR, Benjamin; CARA, Salete de Almeida (orgs.) Via Atlântica. São Paulo: CELP/FFLCH/USP, n. 13, 2008, p. 155-163.

MIRANDA, Hermínio de. Eça de Queiroz e Machado de Assis. Vamos Ler. Rio de Janeiro, n. 485, p. 52-60, nov. 1945.

MOISÉS, Massaud. Eça de Queirós e seu ideário estético. Quinto Império. Salvador, v. 5, p. 67-85, jul./dez. 1995.

MÓNICA, Maria Filomena. Eça de Queirós. Lisboa: Quetzal Editores, 2001.

MONTEIRO, Mário. Eça de Queiroz e o Brasil. Vamos Ler. Rio de Janeiro, n. 269, p. 2223/52, set. 1941 .

MOOG, Viana. Eça de Queirós e o século XIX. Porto Alegre: Livraria Globo, 1938. Prefácio. In: MOOG, Viana. Eça de Queiroz: Homens e ideias do século XIX. Rio de Janeiro: Dois Mundos, 1942.

NASCIMENTO, José Leonardo. O Primo Basílio na imprensa brasileira do século XIX. São Paulo: Editora UNESP, 2008.

NEVES, Berilo. Eça de Queirós, romântico ou naturalista? Rio de Janeiro: Imprensa Nacional, 1951.

NEVES, João Alves das. As páginas brasileiras de Eça de Queirós. In: MINÉ, Elza (org.). 150 anos com Eça de Queirós - Anais do III Encontro Internacional de Queirosianos. São Paulo: Centro de Estudos Portugueses/FFLCH/USP, 1997, p. 250-261.

NUNES, Cassiano. O lusitanismo de Eça de Queiroz. Rio de Janeiro: CEB, 1947.

OLIVEIRA, José Lopes de. Eça de Queirós. História das suas obras contada por ele mesmo. Lisboa: Vida Mundial Editora, 1944.

OLIVEIRA, Paulo Motta. Gilberto Freyre leitor de Eça. In: SCARPELLI, Marli Fantini; OLIVEIRA, Paulo Motta (orgs.). Os centenários. Eça, Freyre, Nobre. Belo Horizonte: FALE/UFMG, 2001, p. 341-352. 
OLIVEIRA, Valdemar de. Eça, Machado, Castro Alves, Nabuco... e o teatro. Recife: Universidade Federal de Pernambuco, 1967.

PADILHA, Laura Cavalcante. O espaço do desejo: uma leitura de "A Ilustre Casa de Ramires”. Niterói/Brasília, EDUFF/Editora UnB, 1989.

PAIVA, José Rodrigues de. Breve notícia sobre a recepção de Eça de Queirós no Recife. In: MINÉ, Elza (Org.). 150 anos com Eça de Queirós - Anais do III Encontro Internacional de Queirosianos. São Paulo: Centro de Estudos Portugueses/FFLCH/USP, 1997, p. 576-582.

PALEÓLOGO, Constantino. Eça, literária, psicoanaliticamente. Rio de Janeiro: Cruzeiro, 1948.

Eça de Queirós e Machado de Assis. S.l.: INL, 1979.

PEIXOTO, Afrânio. Como Disse Eça de Queiroz. Lisboa: Lello e Irmão Editores, 1949.

PEREIRA, Edgard. O olhar descentrado de Eça. In: SCARPELLI, Marli Fantini; OLIVEIRA, Paulo Motta (orgs.). Os centenários. Eça, Freyre, Nobre. Belo Horizonte: FALE/UFMG, 2001, p. 63-73.

PINTO, E.G. Eça de Queirós. São Paulo: s.e., 1988.

POUSADA, Antonio. Vida, paixão e morte de Eça de Queiroz. São Paulo: Clube do Livro, 1966.

NEVES, Berilo. Eça de Queirós, romântico ou naturalista? Rio de Janeiro: Imprensa Nacional, 1951.

RAMALHETE, Clóvis. Eça de Queiroz. São Paulo: Livraria Martins, 1942.

RAMOS, Feliciano. Eça de Queirós e os seus últimos valores. Lisboa: Revista Ocidente, 1945.

RAMOS Jr., José de Paula. A Ilustre Casa de Ramires. São Paulo: Ática, 1993.

RÊGO, José Lins do. Gordos e Magros. Ensaios. Rio de Janeiro: Casa Editorial do Brasil, 1942.

REIS, António Simões dos. Eça de Queiroz no Brasil. Rio de Janeiro: Zelio Valverde, 1945. 
REIS, Carlos. Estatuto e perspectivas do narrador na ficção de Eça de Queirós. Coimbra: Almedina, 1975.

; MILHEIRO, Maria do Rosário. A construção da narrativa queirosiana: o espólio de Eça de Queirós. Lisboa: Imprensa Nacional - Casa da Moeda, 1989.

. Estudos queirosianos. Lisboa: Editorial Presença, 1999.

. Eça de Queirós: passos de um trajeto. Revista da Biblioteca Mário de Andrade. São Paulo: Secretaria Municipal de Cultura, 2000, p. 207-214.

. Leitores brasileiros de Eça de Queirós: algumas reflexões. In: ABDALA JÚNIOR, Benjamin (Org.). Ecos do Brasil: Eça de Queirós, leituras brasileiras e portuguesas. São Paulo: SENAC, 2000, p. 23-37.

. Os silêncios de Eça. In: ZILBERMAN, Regina (et al.) Eça e outros: diálogos com a ficção de Eça de Queirós. Porto Alegre: EDIPUCRS, 2002, p. 21-35.

. O essencial sobre Eça de Queirós. Lisboa: Imprensa Nacional - Casa da Moeda, 2005.

ROLLEMBERG, Marcello (org. e apres.). Quando tínhamos verbos: frases, citações e pensamentos de Eça de Queirós. Rio de Janeiro: Record, 2000.

A face real do imaginado. Cult. São Paulo, ano IV, n. 38, 2000, p. 54-57.

ROMERO, Sílvio. Machado de Assis: estudo comparativo de literatura brasileira. São Paulo: Editora da UNICAMP, 1992.

ROSA, Alberto Machado da. Eça, discípulo de Machado? Lisboa: Editorial Presença, 1964.

SÁ, Victor de. Bibliografia queirosiana. S.l.: Braga, 1945.

SACRAMENTO, Mário. Eça de Queirós: uma estética da ironia. Coimbra: Coimbra Editora, 1945.

SARAIVA, Antônio José. As idéias de Eça de Queirós. Lisboa: Bertrand, 1982. A tertúlia literária. 2.ed. Lisboa: Público, 1996.

SCANTIMBURGO, João de. Eça de Queiroz e a tradição. Lisboa: Universitária Editora, 1998. 
SCARPELLI, Marli Fantini; OLIVEIRA, Paulo Motta (Orgs.). Os centenários. Eça, Freyre, Nobre. Belo Horizonte: FALE/UFMG, 2001.

. Ecos de Eça em Machado. In: SCARPELLI, Marli Fantini; OLIVEIRA, Paulo Motta (Orgs.). Os centenários. Eça, Freyre, Nobre. Belo Horizonte: FALE/UFMG, 2001, p. 299-313.

- Machado de Assis \& Eça de Queirós: atos de fingir, desnudamento da ficcionalidade. In: FERNANDES, Annie Gisele; OLIVEIRA, Paulo Motta. Literatura portuguesa aquém-mar. Campinas: Editora Komedi, 2005, p. 91-105.

SILVA, A. Casemiro de. Eça e Wilde. Rio de Janeiro: Livraria São José, 1962.

SILVA, Maurício. Eça de Queirós: influências. Revista do Centro de Estudos Portugueses. São Paulo: FFLCH/USP, n.2, p. 71-74. 1999.

SIMÕES, João Gaspar. Machado de Assis e Eça de Queiroz ou o Humorismo e a Ironia. Revista do Brasil. Rio de Janeiro. Ano IV, n. 37, p. 1-3, jul. 1941.

Eça de Queiroz: o homem e o artista. Lisboa, Rio de Janeiro: Edições Dois Mundos, 1945.

Estudo crítico-biográfico. In: QUEIRÓS, Eça de. Obra Completa. Rio de Janeiro: Companhia José Aguilar, 1970.

Eça de Queirós: a obra e o homem. 3. ed. Lisboa: Arcádia, 1978.

Vida e obra de Eça de Queiroz. 3. ed. Lisboa: Livraria Bertrand, 1980.

SOUZA, José Carlos Siqueira. Eça ensaísta: estudo sobre o trabalho jornalístico de Eça de Queirós para a Gazeta de Notícias, do Rio de Janeiro, ao final do século XIX. São Paulo: 2007. 195f. Dissertação (Mestrado em Estudos Comparados de Literaturas de Língua Portuguesa) - Faculdade de Filosofia, Letras e Ciências Humanas, Universidade de São Paulo, São Paulo.

TRÊPA, José. Eça de Queirós visto pelos seus contemporâneos. Porto: Lello \& Irmão, 1945.

TUPIASSU, Amarílis. Eça de Queirós e os desassossegos da santidade. Belém: Editora da UFPA, 1992.

VIANA FILHO, Luís. A vida de Eça de Queiroz. Porto: Lello \& Irmão, 1983. 
VIDAL, Frederico Perry. Os enigmas n’Os Maias de Eça de Queirós. São Paulo: Green Forest do Brasil, 2001.

WERNECK, Francisco José dos Santos. Idéias de Eça de Queirós. Rio de Janeiro: Agir, 1946.

\section{Crítica e teoria literária geral}

ABREU, Jorge O. Almeida. História da literatura nacional. Rio de Janeiro: Oficinas Gráficas Mundo Médico, 1930.

ANDRADE, Mário de. Aspectos da literatura brasileira. 5.ed. São Paulo: Martins, 1974.

ARANTES, Paulo Eduardo. Sentimento da dialética na experiência intelectual brasileira. Rio de Janeiro: Paz e Terra, 1992.

ATAÍDE, Tristão de. Meio século de presença literária. Rio de Janeiro: José Olympio, 1969.

BAKHTIN, M. Marxismo e filosofia da linguagem: problemas fundamentais do método sociológico na ciência da linguagem. São Paulo: Hucitec, 1979.

BARBOSA, João Alexandre. Metáfora crítica. São Paulo: Perspectiva, 1974.

(org). Textos críticos. São Paulo: Perspectiva/INL, 1986.

. Forma e história na crítica brasileira de 1870-1950. Transformations of Literary

Language in Latin American Literature: From Machado de Assis to the Vanguards. Texas: University of Texas at Austin, 1987, p. 1-11.

A crítica literária. São Paulo: Martins Fontes, 1988.

A leitura do intervalo - ensaios de crítica. São Paulo: Iluminuras, 1990.

BARTHES, Roland. A morte do autor. In: O rumor da língua. Lisboa: Edições 70, 1987.

BELLO, José Maria. Retrato de Machado de Assis. Rio de Janeiro: Editora Noite, 1952.

BOLLE, Adélia Bezerra de Meneses. A obra crítica de Álvaro Lins e sua função histórica. Petrópolis: Vozes, 1979. 
BONNICI, Thomas. O Pós-Colonialismo e a literatura. Maringá: EDUEM, 2000.

; ZOLIN, Lúcia Osana (org.). Teoria literária. Abordagens históricas e tendências contemporâneas. 2. ed. Maringá: EDUEM, 2005.

BORDIEU, Pierre. A economia das trocas simbólicas. São Paulo: Perspectiva, 1974.

As regras da arte: gênese e estrutura do campo literário. São Paulo: Cia. das Letras, 1996.

BOSI, Alfredo. História concisa da literatura brasileira. São Paulo: Cultrix, 1980.

BRAIT, B. (org.) Bakhtin, dialogismo e construção do sentido. Campinas: Editora da Unicamp, 1997.

BRASIL, Antonio. O pensamento crítico de Álvaro Lins. Rio de Janeiro: José Olympio, 1985.

BRASIL, Assis. Teoria e prática da crítica literária. Rio de Janeiro: Topbooks, 1995.

BROCA, Brito. A vida literária no Brasil - 1900. Rio de Janeiro: José Olympio, 1960.

CÂNDIDO, Antonio. Literatura e sociedade. São Paulo: Editora Nacional, 1985.

A Educação pela noite e outros ensaios. São Paulo: Ática, 1987.

Formação da literatura brasileira. Rio de Janeiro: Ouro sobre Azul, 2006.

CAMPOS, Humberto de. Crítica. Rio de Janeiro: José Olympio, 1935.

CARONE, Modesto. A poética do silêncio. São Paulo: Perspectiva, 1979.

CARPEAUX, Otto Maria. Crítica literária. Letras e Artes. Rio de Janeiro, n. 50, p. 1, jan. s.d.

CARVALHO, Ronald de. Estudos brasileiros. Rio de Janeiro: Nova Aguiar, 1976.

CASTELLO, José Aderaldo. A literatura brasileira: origens e unidade. São Paulo: EDUSP, 2004. v. 1 e 2.

CHAIA, Miguel. Biografia: método de reescrita da vida. In: HISGAIL, Fani (org.) Biografia: sintonia da cultura. São Paulo: CESPUC, 1996, p. 75-82.

COELHO, Eduardo Prado. Os universos da crítica: paradigmas nos estudos literários. Lisboa: Edições 70, 1987. 
COELHO, Marcelo. Jornalismo e crítica. In: MARTINS, Maria Helena (org.). Rumos da crítica. São Paulo: SENAC, 2000, p. 83-94.

COUTINHO, Afrânio. Da crítica e da nova crítica. Rio de Janeiro: Civilização Brasileira, 1957.

. A crítica. Salvador: Progresso, 1957.

A tradição afortunada: o espírito de nacionalidade na crítica brasileira. Rio de Janeiro: José Olympio, 1968.

. Crítica \& Críticos. Rio de Janeiro: Simões, 1969.

(org.). Caminhos do pensamento crítico. Rio de Janeiro: Pallas; Brasília: INL, 1980. v. 1 e 2.

A literatura no Brasil. 3. ed. Rio de Janeiro: José Olympio, 1986.

DOSSE, François. O desafio biográfico: escrever uma vida. São Paulo: EDUSP, 2009.

EAGLETON, Terry. A função da crítica. São Paulo: Martins Fontes, 1991.

. Teoria da literatura. São Paulo: Martins Fontes, 1994.

FERREIRA, Pinto. Interpretação da literatura brasileira. Rio de Janeiro: José Konfino Editor, 1957.

FIGUEIREDO, Fidelino de. História da literatura realista. São Paulo: Anchieta, 1946.

FOUCAULT, Michel. O que é um autor? Lisboa: Veja, 1992.

FRYE, Northrop. Anatomia da crítica. São Paulo: Cultrix, 1973.

GRIECO, Agripino. Evolução da prosa brasileira. Rio de Janeiro: Ariel, 1933.

Machado de Assis. Rio de Janeiro: José Olympio, 1959.

HALLEWELL, Laurence. O livro no Brasil: sua história. São Paulo: T. A. Queiroz, 1985.

JOBIM, José Luis (org.). Palavras da crítica. Rio de Janeiro: Imago, 1992.

LAFETÁ, João Luiz. 1930 - a crítica e o modernismo. São Paulo: Duas Cidades, 1974.

LEITE, D.M. O caráter nacional brasileiro: história de uma ideologia. 3. ed. São Paulo: Pioneiro, 1976.

LIMA, Alceu Amoroso. O crítico literário. Rio de Janeiro: Agir, 1945. 
A crítica literária no Brasil. Rio de Janeiro: Biblioteca Nacional, 1959.

LIMA, Luiz Costa. A literatura e o leitor. São Paulo: Paz e Terra, 1979. Teoria da literatura em suas fontes. Rio de Janeiro: Francisco Alves, 1983. v.1 e

2.

LINS, Álvaro. Literatura e vida literária: diário e confissões. Rio de Janeiro: Civilização Brasileira, 1963.

LOBO, L. Leitor. In: JOBIM, J. L. (org.). Palavras da crítica. Rio de Janeiro: Imago, 1992, p. 231-251.

LYRA, Pedro. Para um conceito de crítica. Letras de Hoje. Porto Alegre, n. 16, p. 79, 1983.

MARTINS, Maria Helena (org.). Rumos da crítica. São Paulo: SENAC, 2000.

MARTINS, Wilson. A crítica literária no Brasil. Rio de Janeiro: Francisco Alves, 2002. v. 1 e 2 .

Pontos de vista: crítica literária. São Paulo: T. A. Queiroz, 1991. v. 1-11.

MAUROIS, André. Aspects de la Biographie. Paris: Au Sans Pareil, 1928.

MELO E CASTRO, Ernesto M. de. Voos da fênix crítica. Lisboa: Edições Cosmos, 1995.

MIGUEL-PEREIRA, Lúcia. Machado de Assis: estudo crítico e biográfico. 4. ed. São Paulo: Editora Brasileira, 1949.

História da literatura brasileira: prosa de ficção - de 1870 a 1920. Belo Horizonte: Itatiaia; São Paulo: EDUSP, 1988.

Escritos da maturidade. Rio de Janeiro: Graphia Editorial, 1994.

MOTTA, Leda Tenório da. Sobre a crítica literária no último meio século. Rio de Janeiro: Imago, 2002.

NEVES, João Alves das. As relações literárias de Portugal com o Brasil. Lisboa: Icalp, 1992.

NUNES, Benedito. Crítica literária no Brasil, ontem e hoje. In: MARTINS, Maria Helena (org.). Rumos da crítica. São Paulo: SENAC, 2000, p. 51-79.

PERRONE-MOISÉS, L. Falência da crítica. São Paulo: Perspectiva, 1973.

. Texto, crítica, escritura. São Paulo: Ática, 1978.

Flores da escrivaninha. São Paulo: Companhia das Letras, 1990. 
REIS, Carlos. Técnicas de análise textual. 3. ed. Coimbra: Almedina, 1981.

ROGER, Jérôme. A crítica literária. Rio de Janeiro: DIFEL, 2002.

SANTIAGO, Silviano. Uma literatura nos trópicos: ensaios sobre dependência cultural. São Paulo: Perspectiva, 1978.

SCHWARZ, Roberto. Ao vencedor, as batatas. São Paulo: Duas Cidades, 1977. Que horas são? São Paulo: Companhia das Letras, 1987.

TADIÉ, Jean-Yves. A crítica literária no século XX. Rio de Janeiro: Bertrand Brasil, 1992.

VERÍSSIMO, José. Teoria, crítica e história literária. São Paulo: EDUSP, 1978.

VIANA FILHO, Luiz. A verdade na biografia. Rio de Janeiro, São Paulo, Bahia: Civilização Brasileira, 1945.

VIEIRA, Nelson. Brasil e Portugal: a imagem recíproca: o mito e a realidade na expressão literária. Lisboa: Instituto de Cultura e Língua Portuguesa, Diálogo: Fronteiras Abertas, 1991.

WELLEK, René. Conceitos de crítica. São Paulo: Cultrix, 1963.

WELLEK, René; WARREN, A. Teoria da literatura. S.l.: Publicações Europa-América, 1976.

. História da crítica moderna (1750-1950). Madrid: Gredos, 1988.

WILDE, Oscar. O crítico como artista. In: __ Obra completa. 5. ed. Rio de Janeiro: Nova Aguilar, 1993, p. 1110-1164. 